CARLA PIMENTEL DE CASTRO

\title{
AVALIAÇÃO AMBIENTAL INTEGRADA \\ E INTERVENÇÕES PROJETUAIS \\ NA HEMORREDE NO BRASIL
}

BRASÍLIA

2016 
CARLA PIMENTEL DE CASTRO

\section{AVALIAÇÃO AMBIENTAL INTEGRADA E INTERVENÇÕES PROJETUAIS NA HEMORREDE NO BRASIL}

Dissertação apresentada ao Programa de Pós Graduação em Arquitetura e Urbanismo da Universidade de Brasília como requisito para obtenção do título de Mestre em Arquitetura e Urbanismo.

BANCA DE DEFESA

Prof. Dra. Marta Adriana Bustos Romero

Prof. Dra. Eliete de Pinho de Araujo

Prof. Dr. Márcio Augusto Roma Buzar 


\section{SUMÁRIO}

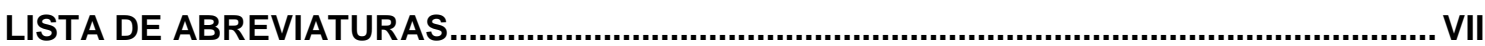

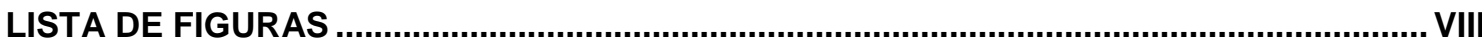

LISTA DE TABELAS

LISTA DE QUADROS

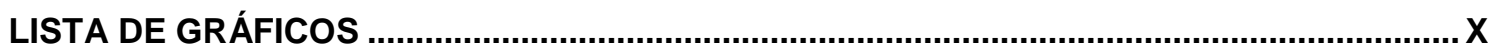

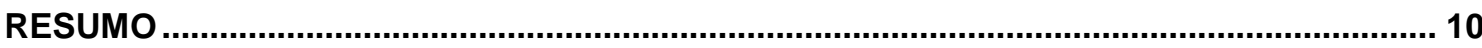

ABSTRACT

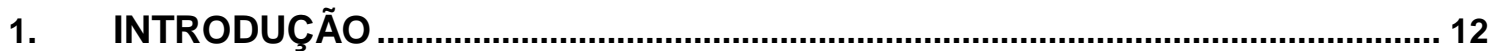

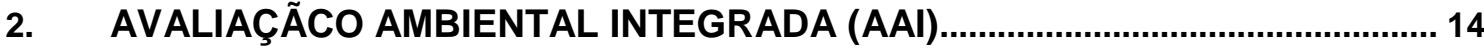

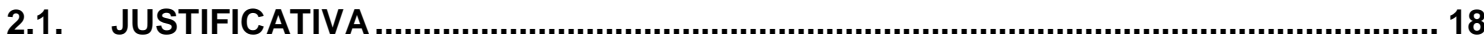

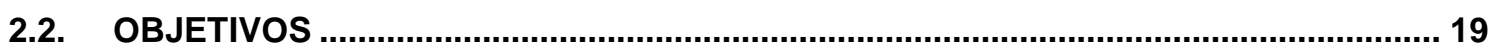

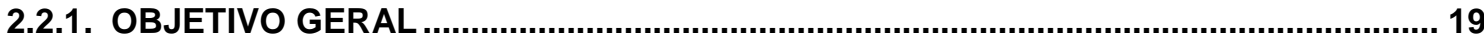

2.2.2. OBJETIVOS ESPECÍFICOS ....................................................................................... 19

3. ESTRUTURA DA DISSERTAÇÃO

4. EDIFICAÇÕES DE ASSISTÊNCIA À SAÚDE NO BRASIL (EAS) .............................. 21

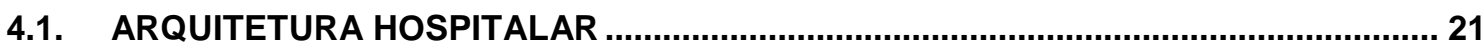

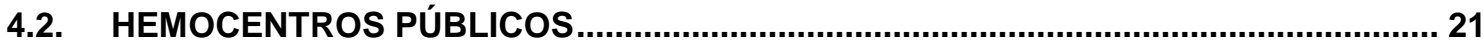

5. ARQUITETURA BIOCLIMÁTICA

5.1. ASPECTOS BIOCLIMÁTICOS NO BRASIL ............................................................... 30

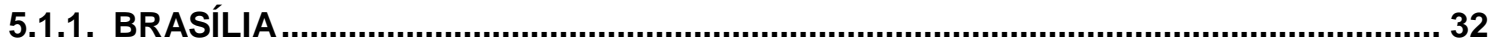

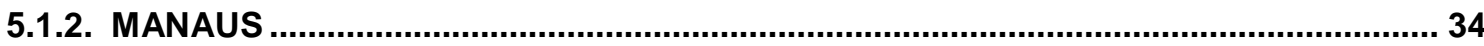

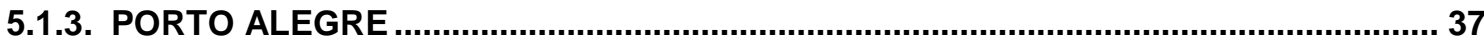

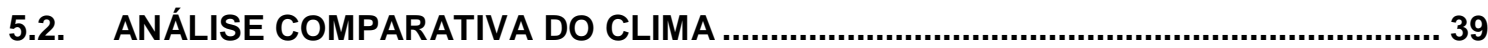

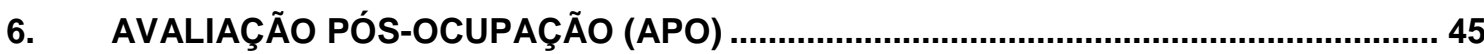

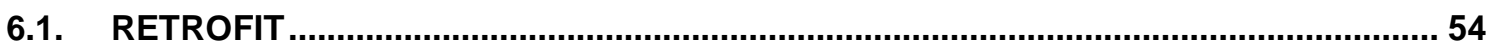

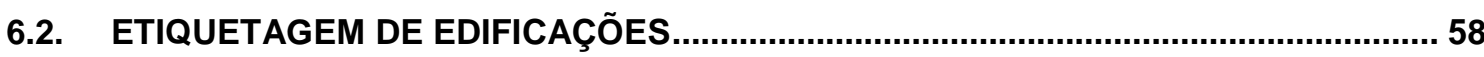

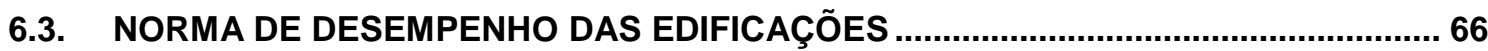

6.4. BIM - A REVOLUÇÃO DAS FERRAMENTAS COMPUTACIONAIS............................ 71 
6.5. PROCEDIMENTOS DE MANUTENÇÃO EM EAS

7. CONTEXTUALIZAÇÃO DAS EDIFICAÇÕES............................................. 92

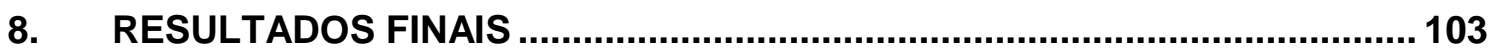

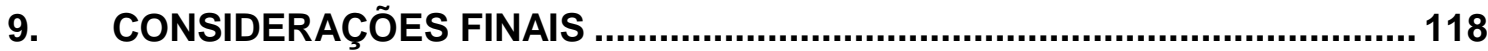

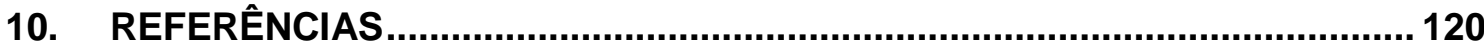




\section{LISTA DE ABREVIATURAS}

2D

3D

AAI

ABNT

AEC

APO

CAU

CBIC

CREA

EAS

HEMOAM

HEMODF

HEMORGS

LASUS

PIB

SUS

TRY

VU
Duas Dimensões

Três Dimensões

Avaliação Ambiental Integrada

Associação Brasileira de Normas Técnicas

Arquitetura, Engenharia e Construção

Avaliação Pós Ocupação

Conselho de Arquitetura e Urbanismo

Câmara Brasileira da Indústria da Construção

Conselho Regional de Arquitetura e Urbanismo

Estabelecimento Assistencial de Saúde

Hemocentro Manaus

Hemocentro Brasília

Hemocentro Porto Alegre

Laboratório de Sustentabilidade Aplicada à Arquitetura e ao

Urbanismo/UnB

Programa Brasileiro de Etiquetagem

Produto Interno Bruto

Sistema Único de Saúde

Test Reference Year

Vida Útil 


\section{LISTA DE FIGURAS}

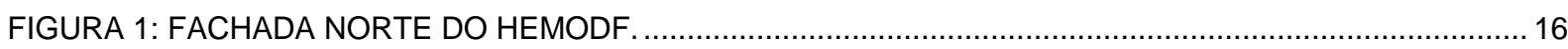

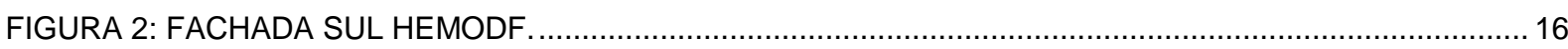

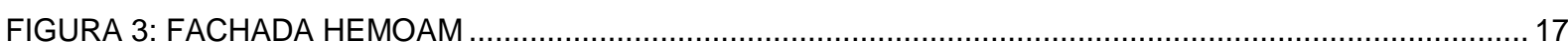

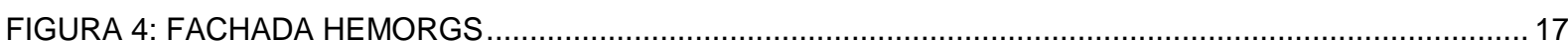

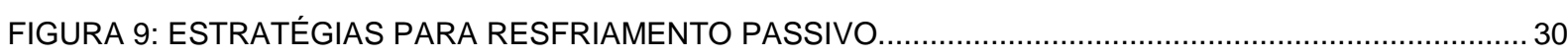

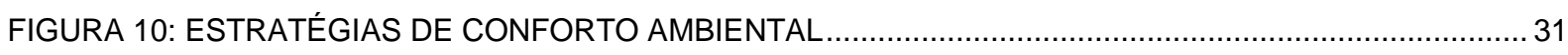

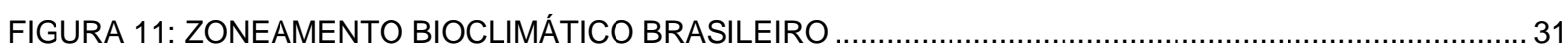

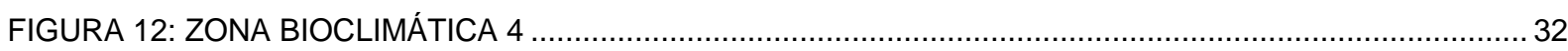

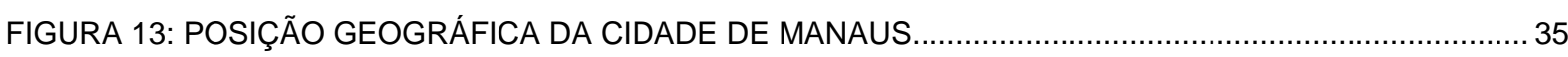

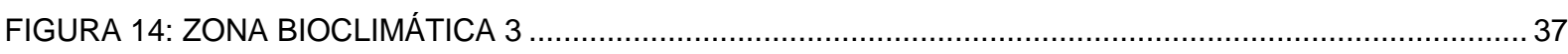

FIGURA 15: EXEMPLO DE RETROFIT. FOTO ANTES E DEPOIS -PRAÇA XV EM PORTO ALEGRE ..............55

FIGURA 16: CINCO SISTEMAS PARA AVALIAÇÃO DO DESEMPENHO DAS EDIFICAÇÕES...........................67

FIGURA 17: ATUAIS PROBLEMAS ENFRENTADOS PARA ADOÇÃO DA PLATAFORMA BIM NA

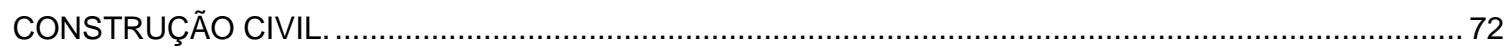

FIGURA 18: FACHADA RENDERIZADA NO SKETCH UP - INCIDÊNCIA SOLAR. ............................................. 77

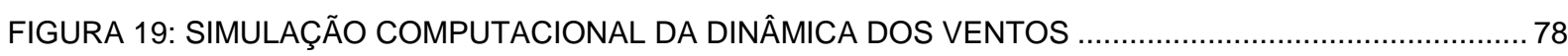

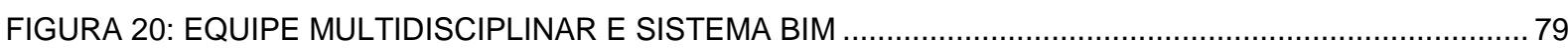

FIGURA 21: SUGESTÃO DE FLUXOGRAMA PARA ELABORAÇÃO DE PROJETOS DE HEMOCENTROS ... 104

FIGURA 22: FLUXOGRAMA SUGERIDO PARA O SETOR RECEPÇÃO-DOADOR-SANGUE ......................... 105

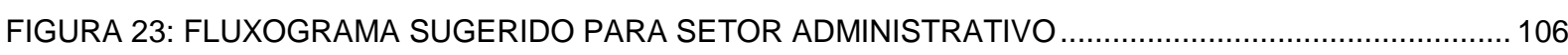

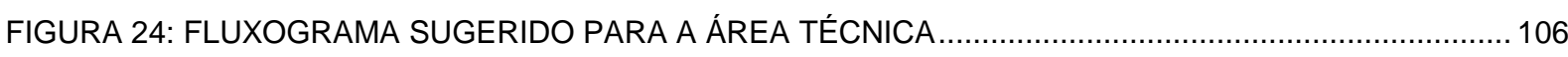

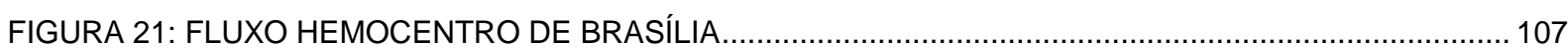

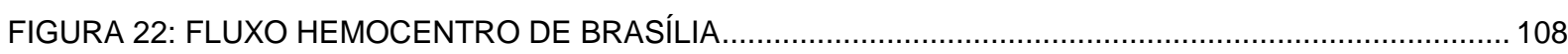

FIGURA 23: PLANTA DE SETORIZAÇÃO-AMBIENTES HEMOCENTRO DE BRASÍLIA …............................. 108

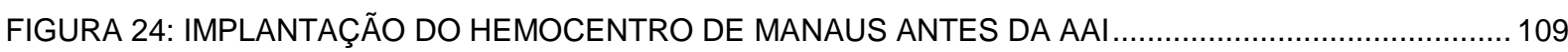

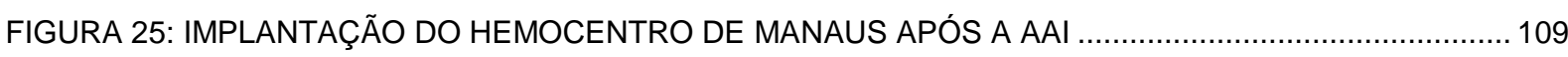

FIGURA 26: PAVIMENTO TÉRREO, PRIMEIRO, SEGUNDO E TERCEIRO PAVIMENTOS DO HEMOCENTRO

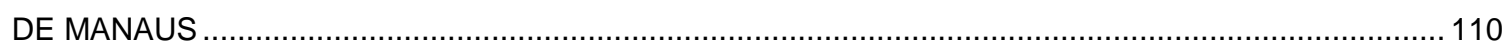

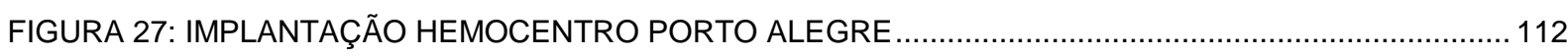

FIGURA 28: SISTEMA DE ILUMINAÇÃO E VENTILAÇÃO - HEMORGS .....................................................113

FIGURA 29: FLUXOGRAMA SUGERIDO PARA ELABORAÇÃO DE PLANO DE MANUTENÇÃO.....................113 


\section{LISTA DE TABELAS}

TABELA 1: INVESTIMENTOS DO ORÇAMENTO PÚBLICO EM SANGUE E HOMODERIVADOS, EM R\$

MILHÕES POR ANO.

TABELA 2: RELAÇÃO MESES X TEMPERATURA X PRECIPITAÇÃO DE BRASÍLIA …..................................... 34

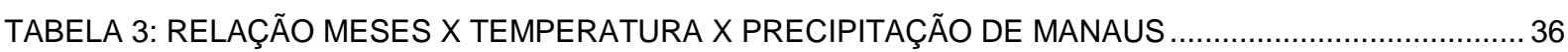

TABELA 4: RELAÇÃO MESES X TEMPERATURA X PRECIPITAÇÃO DE PORTO ALEGRE ............................39

TABELA 5: COMPARAÇÃO ENTRE AS ZONAS BIOCLIMÁTICAS DE MANAUS, BRASÍLIA E PORTO ALEGRE

TABELA 6: COMPARAÇÃO ENTRE OS CLIMAS E CARACTERÍSTICAS DAS CIDADES EM ESTUDO. ........... 42

TABELA 7: COMPARAÇÃO DA UMIDADE DO AR NAS CIDADES EM ESTUDO. ......................................... 43

TABELA 8: COMPARAÇÃO DA TEMPERATURA ENTRE AS CIDADES ESTUDADAS ..................................... 43

TABELA 9: COMPARAÇÃO ENTRE ÍNDICES PLUVIOMÉTRICOS NAS CIDADES ANALISADAS. ................... 44

TABELA 10: EQUIVALENTE NUMÉRICO PARA CADA NÍVEL DE EFICIÊNCIA (EQNUM) …........................... 62

TABELA 11: CLASSIFICAÇÃO FINAL DA EDIFICAÇÃO CONFORME PONTOS OBTIDOS NA EQUAÇÃO....... 62

TABELA 12: LIMITE MÁXIMO ACEITÁVEL DE DENSIDADE DE POTÊNCIA DE ILUMINAÇÃO PARA O NÍVEL

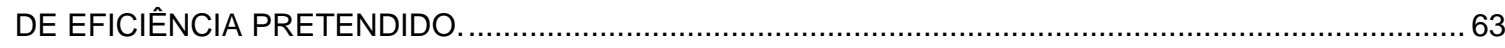

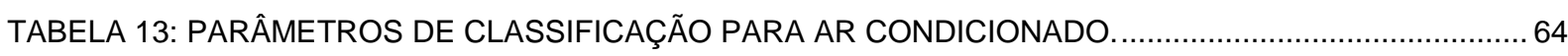

TABELA 14: PARÂMETROS DE CLASSIFICAÇÃO PARA CONDICIONADOR DE AR TIPO SPLIT..................... 64

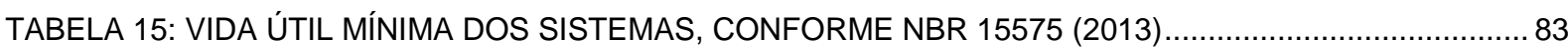

TABELA 17: INDICAÇÃO DO LOCAL E RESÍDUOS SÓLIDOS GERADOS, DIVIDIDOS EM GRUPOS. .............87

TABELA 18: TABELA PROPOSTA POR ARAUJO (2013) PARA GERENCIAMENTO DE RESÍDUOS EM EAS. 88

TABELA 19: DESTINAÇÃO E TRATAMENTO DOS RESÍDUOS CONFORME GRUPOS. ................................... 88

TABELA 20: PROPOSTA DE TABELA PARA AVALIAÇÃO ENTRE RISCO E CUSTO NO GERENCIAMENTO

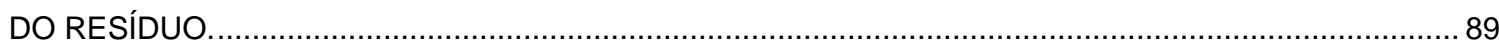

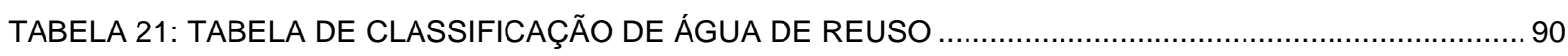




\section{LISTA DE QUADROS}

QUADRO 1: NÍVEIS DE COMPLEXIDADE DE SERVIÇOS DE HEMOTERAPIA E LEGISLAÇÃO - EXIGÊNCIAS

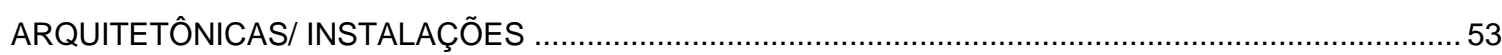

QUADRO 2: ETAPAS DO RETROFIT SEGUNDO NUNES (2012) ................................................................... 56

QUADRO 3: CRITÉRIOS PARA SELEÇÃO DE MATERIAIS APLICADOS EM AÇÕES DE RETROFIT ...............57

QUADRO 4: CARACTERÍSTICAS URBANÍSTICAS, SIMULAÇÕES E INADEQUAÇÕES DAS EDIFICAÇÕES . 94

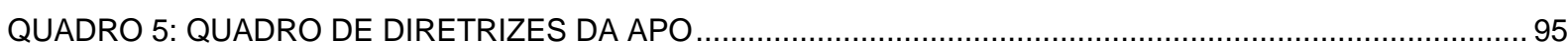

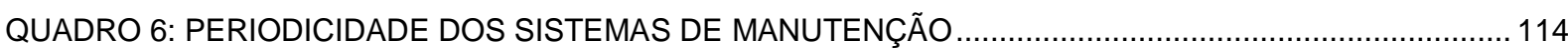

\section{LISTA DE GRÁFICOS}

GRÁFICO 1: INVESTIMENTOS DO ORÇAMENTO PÚBLICO EM SANGUE E HOMODERIVADOS, EM R\$

MILHÕES POR ANO.

GRÁFICO 2: RELAÇÃO MESES X ÍNDICE PLUVIOMÉTRICO DE BRASÍLIA X TEMPERATURA...................... 33

GRÁFICO 3: GRÁFICO CLIMÁTICO-RELAÇÃO MESES X TEMPERATURA DE BRASÍLIA..............................33

GRÁFICO 4: RELAÇÃO MESES X ÍNDICE PLUVIOMÉTRICO DE MANAUS ................................................... 36

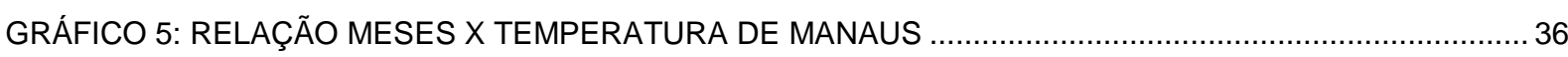

GRÁFICO 6: RELAÇÃO MESES X ÍNDICE PLUVIOMÉTRICO DE PORTO ALEGRE X TEMPERATURA. .......... 38

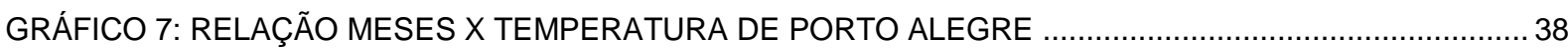

GRÁFICO 8: EVOLUÇÃO DO CONSUMO DE ENERGIA ELÉTRICA EM ALGUNS PAÍSES ENTRE 1960-2008.

GRÁFICO 9: RELAÇÃO ENTRE CONSUMO DE ENERGIA ELÉTRICA E PIB.

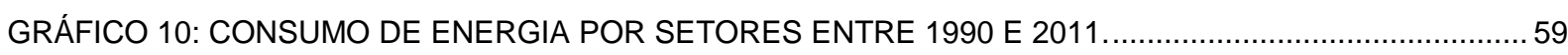

GRÁFICO 11: USO FINAL DO CONSUMO DE ELETRICIDADE TOTAL NO SETOR RESIDENCIAL EM 2005.. 60 GRÁFICO 12: COMPARAÇÃO ENTRE O TEMPO DE PROJETO, DOCUMENTAÇÃO E COORDENAÇÃO EM

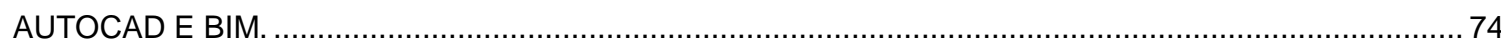

GRÁFICO 13: DESEMPENHO DA EDIFICAÇÃO AO LONGO DO TEMPO - TEMPO DE MANUTENÇÃO. ........ 83

GRÁFICO 14: QUADRO DE CONSUMO ENERGÉTICO DO HEMODF ......................................................... 101

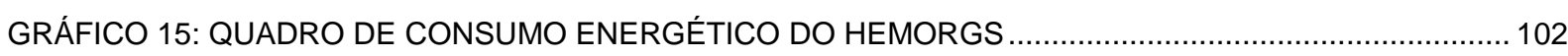

GRÁFICO 16: QUADRO DE CONSUMO ENERGÉTICO DO HEMOAM ......................................................... 102 


\section{RESUMO}

As edificações possuem dois estágios de vida: a fase de produção e a fase de uso, operação e manutenção. Poucas pesquisas são voltadas para a segunda fase, retratando uma vida útil reduzida pela ausência de análise preventiva. No entanto, grande parte dos problemas detectados nas edificações em uso é proveniente da fase anterior, da etapa projetual. A intenção deste trabalho é colocar em pauta algumas questões pertinentes à melhoria das duas fases. A Avaliação Ambiental Integrada através da Avaliação Pós Ocupação, Retrofit e Etiquetagem busca reabilitar edificações com alto custo energético e baixo conforto ambiental gerando diretrizes de melhoria tanto projetuais quanto comportamentais. Para o desenvolvimento de um projeto, indica-se que das principais abordagens é necessária a análise prévia do local antes do desenvolvimento do estudo preliminar para que a edificação tenha além de um melhor desempenho energético, maior economia. Temperatura, ventos, umidade, cultura e topografia são elementos a serem observados, buscando adequar o partido a uma arquitetura de característica bioclimática, que utilize as características locais como condicionantes da projetação de um ambiente que traga o máximo de conforto ambiental possível. Para isso, fazem-se necessários estudos relativos a novos softwares e ferramentas computacionais que auxiliem tanto na simulação climática quanto no desenvolvimento tecnológico que toda edificação está sujeita ao longo de sua vida útil. Como objeto de estudo deste trabalho tem-se os Hemocentros públicos, focando nas unidades de Brasília, Manaus e Porto Alegre. Edificações de saúde que se apresentam, com baixíssima qualidade do ponto de vista energético e do conforto ambiental. Através de análises e quadros comparativos são traçadas algumas recomendações projetuais, comportamentais, de gestão e também a respeito da sugestão de unificação da normatização existente no Brasil, que podem auxiliar no exercício de projetação e manutenção de edificações de tipologia semelhantes ou locados na mesma zona bioclimática, em busca de expor o tema para futuras discussões e se tornar um facilitador de acertos em projetos similares.

Palavras-chave: Hemorrede, Avaliação Pós Ocupação, Avaliação Ambiental. 


\section{ABSTRACT}

Buildings have two life stages: the production stage and operation and maintenance. Only a few research projects are focused on the second stage, depicting a useful life reduced by the absence of preventive analysis.

However, many of the problems found in buildings in use are from the previous stage of design stage. The intention of this work is that to focus on some issues pertaining to improvement of two phases. The Integrated Environmental Assessment by the Post Occupancy Evaluation, Retrofit and Labeling search rehabilitate buildings with high energy costs and low environmental comfort to generate improvement in projective and behavioral guidelines.

To develop a project, its indicated that the first approach is to focus on previous site analysis prior to the development of the preliminary study, which is necessary for the building has in addition to improve energy performance and greater economy. Temperature, wind, humidity, culture and topography, are elements to be observed, seeking to adapt the party to a bioclimatic characteristic architecture, using local characteristics to project the conditions of an environment that will bring maximum environmental comfort. For this, studies for new software and computational tools become necessary to help both climate simulation and technological development that every building suffers over the time. The building that becomes the object of study of this work is public blood centers, focusing on units of Brasilia, Manaus and Porto Alegre. Health buildings that present very low quality from the energy point of view and the environmental comfort.Through analysis and comparative measure are drawn some projective recommendations, behavioral, management and also about the unification of existing standard suggestion in Brazil, which can assist in the exercise of project and maintenance of similar type of buildings or leased in the same area bioclimatic, seeking to expose the subject to future discussions and become a hit facilitator in similar projects.

Keywords: Blood Center, Evaluation After Occupation, Environmental Assessment. 


\section{INTRODUÇÃO}

A sociedade começou a se preocupar com o consumo energético a partir de 1973, com a Crise do Petróleo, quando os países do Oriente Médio, para proteção comercial, elevaram os preços e diminuíram suas reservas petrolíferas, levando a uma alta dos preços e a busca recursos alternativos na produção de energia.

A partir de 2001, quando o Brasil viveu uma crise energética, houve uma maior conscientização social sobre o uso racional e a adoção de medidas de eficiência energética para diminuir o consumo, além de buscar alternativas mais sustentáveis. Mediante o cenário adverso e a constatação de que os recursos naturais são finitos, as questões ambientais e climáticas não devem ser encaradas somente em momentos de crise, principalmente quando se observa a intensificação da urbanização e, consequentemente, da implantação de edifícios para atender à crescente demanda populacional das últimas décadas a nível mundial.

No âmbito da arquitetura e urbanismo, encontram-se pesquisas e estudos que envolvem o desenvolvimento de produtos e processos mais eficientes e acessíveis, conjuntamente a uma mudança de comportamento de uso e de consumo das edificações com foco em prolongar sua vida útil ou de detectar melhorias para projetos futuros. Analisar a vida útil dos edifícios, especialmente aqueles de uso público, é uma das contribuições desse campo disciplinar, uma vez que contribui para reutilizar e/ou readaptar edificações já existentes, melhorando os procedimentos de manutenção e, consequentemente, diminuindo os impactos ambientais que novas construções causam.

Além de averiguar as mudanças necessárias e indicar a manutenção mais adequada dos edifícios, as pesquisas voltadas para Avaliação Ambiental Integrada (AAI) demonstram a necessidade de mudanças em todas as fases do projeto, incluindo-se desde a concepção até sua implantação e desempenho da vida útil por meio de medidas preventivas.

Quanto a essa abordagem, destacam-se os estudos desenvolvidos pelo Laboratório de Sustentabilidade (LASUS) da UnB. Seus pesquisadores elaboraram essa metodologia com o intuito de avaliar o ambiente construído, indicando possibilidades de intervenção, sendo um dos objetos de estudo a Hemorrede Brasil, isto é, as edificações de assistência a saúde destinadas aos Hemocentros em diferentes cidades brasileiras.

Desse modo, a proposta desses estudos é combinar métodos de análise em que tem-se: Avaliação Pós-Ocupação (APO), diagnóstico Energético/Retrofit e nível de eficiência energética, que integrados tornam-se instrumentos complementares de avaliação do grau de sustentabilidade para diretrizes de projeto, que compreendem uma visão bioclimática da 
arquitetura e do urbanismo, fundamentais para uma conformação mais sustentável do ambiente construído (ROMERO, 2011).

Dentre as questões abordadas, tem-se a análise do desempenho e da vida útil dos edifícios, especialmente aqueles de uso público. Muitas vezes, o partido arquitetônico ou as soluções projetuais adotadas não contemplam necessidades futuras e adaptações, acarretando custos não previstos ou maiores custos de manutenção. Com isso, avaliar as etapas de projeto da edificação como é indicativo de economia de recursos, evitando reformas e adequações, e prevendo futuras necessidades.

Para isso é necessário avaliar a edificação, seu entorno e sua inserção na cidade, tendo em vista que é recorrente no Brasil a adoção de um projeto padrão, independente dos aspectos bioclimáticos de cada região. Melhorar o desempenho de edificações públicas tem sido um dos objetivos do LASUS/UnB, tendo em vista a adoção da AAI como método de análise e definição de diretrizes projetuais. A partir do diagnóstico de cada uma das EAS, é possível definir medidas que melhorem o desempenho das edificações e possibilitem uma vida útil mais prolongada.

O Brasil é um país de grandes extensões territoriais, situado em diferentes Zonas Bioclimáticas, o implica pesquisas voltadas para a arquitetura bioclimática, indicando pequenas intervenções que possam melhorar sua qualidade ambiental. Partindo das pesquisas já desenvolvidas pelo LASUS em AAls, tomou-se como objeto de estudo três EAS, localizadas em diferentes zonas bioclimáticas a fim de compará-las e elaborar recomendações de boas práticas de projeto conforme as especificidades de cada região. Com isso, tem-se como objeto de estudo as seguintes unidades: Hemocentro Brasília (HEMODF), Hemocentro Manaus (HEMOAM) e o Homocentro de Porto Alegre, Rio Grande do Sul. A escolha dessas três edificações se justifica pelas características climáticas o que possibilita apontar boas práticas para as diferentes zonas bioclimáticas, em que seja possível a proposição de critérios para projetos de mesma natureza. 


\section{AVALIAÇÃO AMBIENTAL INTEGRADA (AAI)}

A AAI é um procedimento que visa melhorar o desempenho das edificações mediante os problemas detectados, adotando-se ações de Retrofit vinculadas à eficiência energética, conforme os padrões de etiquetagem vigentes no Brasil (INMETRO, 2010). Trata-se de um processo de inserção do edifício no âmbito da sustentabilidade, prolongando sua vida útil e diminuindo os custos de manutenção.

O projeto Hemorrede Sustentável ${ }^{1}$ possibilita avaliar as discussões acerca do nível de eficiência energética no Brasil para edifícios públicos, com ênfase àqueles destinados à serviços de saúde e integrantes da rede do Sistema Único de Saúde (SUS).

Os ambientes hospitalares públicos passam a ser objeto de pesquisa sob a ótica da Reabilitação Urbana Sustentável pelo LASUS. O Projeto Hemorrede Sustentável objetiva oferecer intervenções nos espaços edificados com agressões mínimas ao meio ambiente, contribuindo para sua humanização e melhor desempenho ambiental em suas várias dimensões.

A APO apresenta-se como importante instrumento de análise das condições ambientais de edifícios e permite a criação de um banco de dados, em que conste a avaliação comportamental e técnica de um determinado ambiente construído. Quanto à análise técnico-construtiva, destacam-se os aspectos térmico, luminoso, sonoro e ambiental. É por meio da APO que se realiza a aferição das condições ambientais e seu banco de dados possibilita reflexões acerca da fase de planejamento e produção da construção civil.

O diagnóstico da APO permite traçar diretrizes de melhoria da eficiência energética da envoltória do edifício e diminuição do consumo energético da edificação. A aplicação prática dessas proposições ocorrem pelo Retrofit, que abarcam pesquisas e intervenções de soluções técnico-construtivas e materiais visando o conforto ambiental e cumprimento dos requisitos das normas de etiquetagem.

No Brasil, verifica-se o aprimoramento desses estudos avaliativos e, consequentemente, a adoção de soluções mais sustentáveis para os edifícios públicos ainda é incipiente ao contrário de países desenvolvidos que as adotam, apresentando soluções e propostas inovadoras para projetos novos e na readequação dos existentes.

\footnotetext{
1 O Projeto Hemorrede Sustentável é desenvolvido pelo LASUS/UnB, sob coordenação da Prof.. Dr. . $^{\text {a }}$ Marta Romero, desde 2010, em que foram desenvolvidas as AAls dos Hemocentros como resultado da pesquisa. A partir desta avaliação, busca-se melhorar o desempenho dos edifícios mediante os problemas detectados com ações de Retrofit nesta pesquisa em específico. As AAls foram realizadas pelos LASUS, em colaboração com uma equipe de estudantes, arquitetos e engenheiros, com o apoio do Ministério da Saúde e também com a colaboração dos coordenadores dos Hemocentros estudados. Até o momento, foram realizadas seis AAls de Hemocentros no Brasil: em Brasília, Belém, Manaus, Fortaleza, Porto Alegre e Rio de Janeiro. Das seis AAls realizadas até o momento, foram escolhidas três, Brasília, Manaus e Porto Alegre por se localizarem em três zonas bioclimáticas totalmente diferentes apesar de terem semelhanças tipológicas o que leva a refletir sobre a aplicação das estratégias bioclimáticas ao invés de adoção de modelos não são adaptáveis a nenhum clima brasileiro.
} 
O ambiente construído também pode ser avaliado pelo Diagnóstico Energético e de Retrofit. Segundo Romero (2011, p. 3), corresponde a "[...] quaisquer medidas de melhoria e elevação de desempenho de equipamentos e sistemas de edifícios existentes." Sua aplicação está vinculada aos diagnósticos dos aspectos energéticos da APO, tendo em vista a intervenção prática das edificações em análise.

A partir do momento que os problemas são identificados, é possível apresentar um conjunto de soluções ou alterações que possibilitem a reabilitação das edificações em análise, visando, principalmente melhorar seu desempenho. Com isso é possível uma interação mais positiva com o meio ambiente à medida que há diminuição dos impactos causados por elas. Para a análise, têm-se três unidades da Hemorrede, localizadas em diferentes zonas bioclimáticas, o que possibilita maior amplitude acerca das reflexões sobre o desempenho das edificações e sua qualidade ambiental. Assim, a pesquisa analisou três unidades de Hemocentro tendo em vista que, em grande parte, são edificações cujas intervenções nem sempre são documentadas ou não há estudos específicos sobre o desempenho que possuem face a diversos fatores, notadamente aspectos bioclimáticos. Com isso, é possível estabelecer diagnósticos dessas unidades e, a partir disso, indicar boas práticas seja por meio de orientações, manuais ou cartilhas técnicas.

As unidades estudadas são apresentadas abaixo considerando sua localização, características construtivas e arquitetônicas e sua implantação, além da descrição das reformas ou adaptações que tenham sofrido ao longo do tempo. Nessa apresentação, temse a relação entre o edifício e o entorno e as definições volumétricas.

O Hemocentro de Brasília (HEMODF) está localizado na SMHN 3, Conjunto A Bloco 3 - Asa Norte, Brasília - DF. Possui uma arquitetura de caráter modernista, constituído por 02 blocos (Bloco A de 1985 e Bloco B de 2002), que possuem dois pavimentos e subsolos. No Bloco $A$, estão as atividades relacionadas à saúde e no Bloco $B$, as administrativas. Observa-se que houve a apropriação do terreno, com adaptação da topografia, com subsolos enterrados e semi-enterrados (Figuras 1 e 2). 
Figura 1: Fachada Norte do HEMODF.

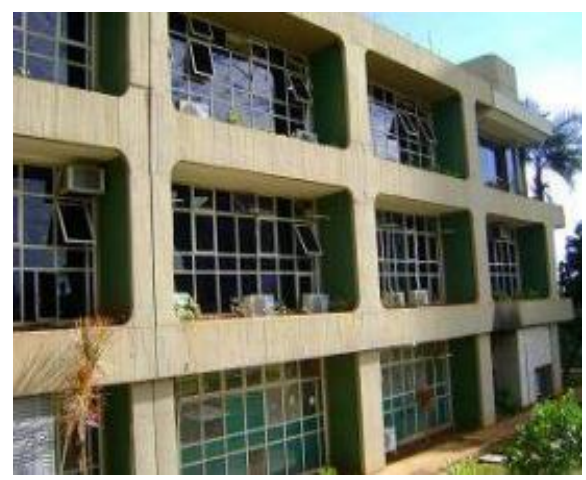

Figura 2: Fachada Sul HEMODF.

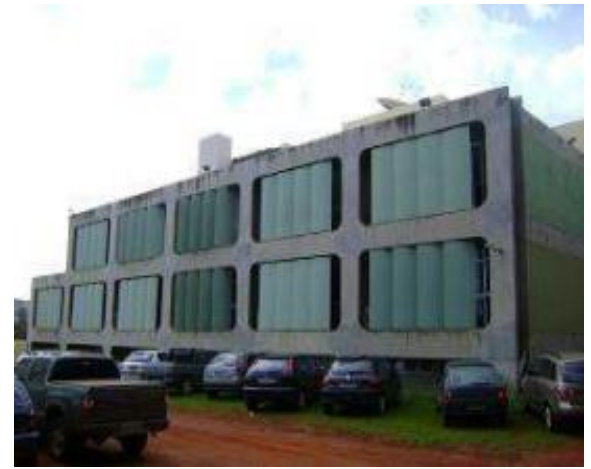

Fonte: LASUS (2011).

Os blocos foram implantados no eixo leste oeste (menor fachada) com morfologia ortogonal e executados em concreto armado, sendo o próprio elemento de composição das fachadas. As maiores fachadas são nas direções norte e sul, predominantemente envidraçadas, mas com proteção mista garantindo proteção à radiação solar, ainda que parcialmente. As fachadas leste e oeste possuem aberturas mais reduzidas, com algumas empenas cegas.

Ao longo desses mais de vinte anos de existência, o HEMODF sofreu várias reformas e adaptações que buscaram atender tanto a evolução tecnológica e científica quanto as diversificadas demandas que surgiram ao longo do tempo. No entanto, muitas dessas reformas desconsideraram critérios para um bom desempenho ambiental ou boas práticas de projeto.

A edificação do Hemocentro Manaus (HEMOAM) é composta por 5 volumes interligados, e, ao mesmo tempo, independentes entre si. Cada bloco é denominado por uma letra: A, B, C, D e E (Figura 3). O complexo edificado está localizado na Avenida Constantino Nery, número 4397, Bairro da Chapada, com área construída de $8.000 \mathrm{~m}^{2}$.

Destaca-se o Plano Diretor Urbano e Ambiental de Manaus e sua relação com esse complexo de saúde. O Plano Diretor está regulamentado por meio da Lei $n^{\circ}$ 671/2002 (PREFEITURA DE MANAUS, 2006). Esse documento define as estratégias de uso e ocupação do solo, tais como: instituir, consolidar e revitalizar centros urbanos dinâmicos; incentivar a adoção de padrões urbanísticos e arquitetônicos condizentes com as características climáticas e culturais de Manaus, com a intenção de melhorar as condições ambientais das edificações e criar uma nova identidade urbanística para a cidade.

O edifício do HEMOAM está localizando na zona de estruturação urbana (UES) e caracteriza-se pela disponibilidade de infraestrutura e serviços urbanos e pela presença de imóveis não utilizados e subutilizados. Para essa zona, o Plano Diretor amplia os níveis de adensamento construtivo, condicionadas à possibilidade de infraestrutura e serviços e à sustentabilidade urbanística e ambiental; também pretende prever a ampliação da disponibilidade e recuperação de equipamentos e espaços públicos. O Plano Diretor 
também pretende prevenir e/ou corrigir efeitos de degradação do ambiente urbano que comprometam a qualidade de vida da população.

Durante o desenvolvimento das atividades de pesquisa, foi discutida a possibilidade de integração deste edifício ao Centro Psiquiátrico Eduardo Ribeiro e ao novo Hospital do Sangue que ocupam terrenos vizinhos, respectivamente a sul e a oeste do Hemocentro. O estudo de AAI, realizado pelo LASUS, já incorporou essa diretriz de unificação das áreas comuns, o que proporcionaria a criação de um espaço público entre os edifícios de saúde com mais qualidade ambiental.

Figura 3: Fachada HEMOAM

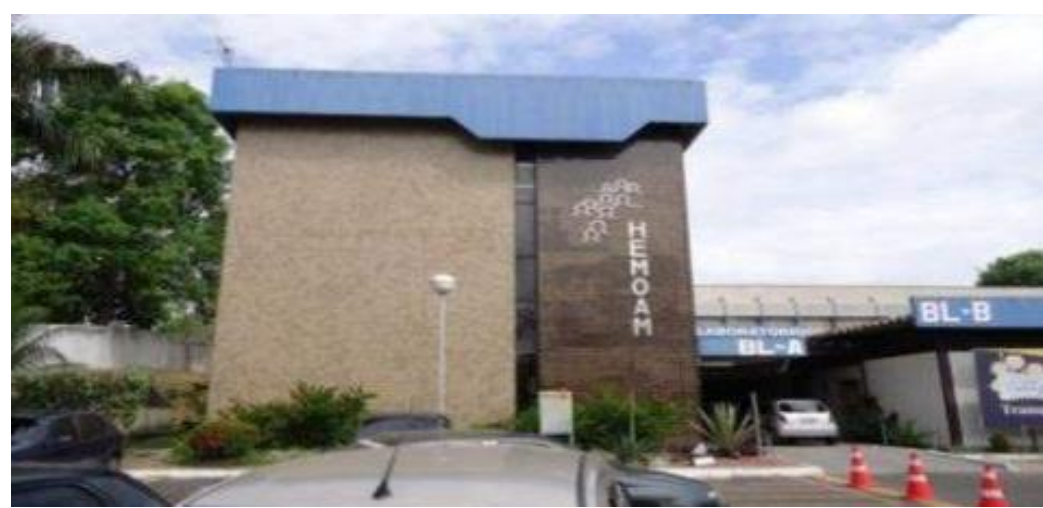

Fonte: LASUS (2015)

O Complexo Hemocentro Porto Alegre (HEMORGS) está situado na Avenida Bento Gonçalves, $n^{\circ} 3790$, no Bairro Parthenon (Figura 5). O Bairro é cortado pela Avenida Bento Gonçalves, uma das principais artérias de Porto Alegre, caracterizada por atividades comerciais, desde pequenos estabelecimentos a hipermercados. A mesma diversificação de oferta ocorre também no que se refere à educação dada a presença de escolas de segundo grau estaduais e particulares, a Pontifícia Universidade Católica do Rio Grande do Sul (PUCRS), (Figura 4), que inaugurou seu Campus Central em 1968, ocupando uma grande área do bairro. A PUCRS com 26 mil alunos de graduação e 3 mil de pós-graduação, constitui um importante ponto de referência da região.

Figura 4: Fachada HEMORGS

Fonte: LASUS (2015)

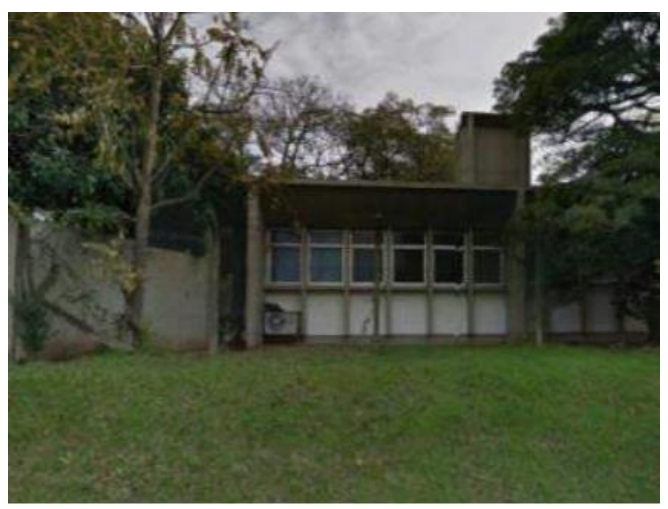




\subsection{JUSTIFICATIVA}

Ao iniciar um projeto de arquitetura, os referenciais projetuais permitem que soluções e adaptações de cada profissional possam ser avaliadas, visualizando, principalmente as regularidades e características comuns. Esse repertório possibilita avaliar as decisões tomadas pelo projetista, apurando os aspectos negativos e positivos das referências projetuais. Ao propor um novo projeto de mesma natureza funcional, os estudos anteriores podem ser aprimorados, principalmente quanto ao desempenho ambiental. Essa tarefa é facilitada quando se dispõe de banco de dados e levantamentos que consideram além da fase de projeto, o uso do edifício em sua plenitude.

Nos projetos de Hemocentros no Brasil, a busca de melhor desempenho ambiental na fase de projeto influencia diretamente na satisfação dos usuários e, consequentemente, melhoria tanto na qualidade de trabalho dos funcionários como na recepção dos doadores que se sentirão mais confortáveis e à vontade para usufruírem do ambiente hospitalar. Isso também se faz necessário, para que a manutenção do edifício ocorra de forma eficiente, prolongando sua vida útil e diminuindo custos de manutenção.

$\mathrm{O}$ avanço das pesquisas científicas em arquitetura e urbanismo, voltadas para a saúde, contribuiu para a ampliação do repertório de publicações com o tema arquitetura hospitalar, notadamente pelas especialidades de tratamento que diversificam as exigências para ambientes hospitalares, tornando o exercício de projetação uma tarefa complexa. No entanto, o que se percebe é que, grande parte das publicações, reforçam as normas técnicas de dimensionamento dos ambientais sem, contudo, abarcar as dimensões de humanização e desempenho ambiental. São aspectos legislativos muito mais vinculados às soluções técnico-construtivas do que recomendações para um melhor desempenho ambiental, visto que, o conforto do usuário é pouco recorrente nas normas definidas pela Vigilância Sanitária, que visam, sobretudo, a definição funcional dos ambientes e requisitos vinculados às demandas de usuários.

Os três Hemocentros foram escolhidos por, apesar de terem o programa de necessidades praticamente semelhantes, se situam em diferentes regiões bioclimáticas. Analisar esse processo permite listar itens que podem ser enquadrados em projetos semelhantes na mesma região e projetos semelhantes em regiões diferentes.

Agendas de pesquisas quanto ao desempenho ambiental, com os procedimentos de AAl fazem-se necessárias para que as edificações possam ser avaliadas quanto aos requisitos de certificações e etiquetagens de eficiência energética. Desse modo, mais do que restringir as pesquisas à fase de projeto, é preciso incorporar a APO, uma fonte mais segura, pois nessa avaliação são utilizados alguns métodos que ampliam o exercício de projetação conjugadas às ações de Retrofit e de nível de eficiência energética. São 
instrumentos de análise do ambiente construído que permitem averiguar o grau de sustentabilidade no qual uma série de soluções são propostas visando a melhoria do nível de desempenho e vida útil das edificações analisadas. Para tanto, tem-se a inter-relação entre o diagnóstico da APO, as ações de Retrofit e a adequação do nível de eficiência energética a fim de retroalimentar a fase de projetação.

O controle de qualidade do ambiente construído torna-se imprescindível para que haja uso, manutenção e operação adequados, avaliando as edificações pelos critérios da arquitetura bioclimática. A partir dessas considerações, avaliar o diagnóstico e as diretrizes de projeto para três Hemocentros do Brasil possibilita dispor de um sistema de gestão e controle da qualidade com o objetivo de apresentar recomendações para sua manutenção e sustentabilidade.

\subsection{OBJETIVOS}

A presente pesquisa tem por objetivo analisar as tecnologias, metodologias e procedimentos técnicos que visam promover a reabilitação das construções e até que ponto essas alterações são possíveis e desejáveis para as edificações analisadas.

Para tanto, são analisadas criticamente as AAls realizadas em três unidades da Hemorrede, como já citado, sistematizando-as a fim de extrair critérios de diagnóstico e avaliação para intervenções nos edifícios e, também, proposição de critérios para projetos de mesma natureza ainda que localizados em distintos contextos e climas.

\subsubsection{Objetivo Geral}

Averiguar quais critérios e recomendações podem ser indicados a edificações dessa natureza, considerando a análises pós-ocupação, normas de etiquetagem de eficiência energética, Retrofits a fim de indicar novos parâmetros de projetação respaldados nas AAls para projetos de mesma natureza.

\subsubsection{Objetivos Específicos}

Avaliação crítica das AAls realizadas nas edificações em estudo por meio de método comparativo com tabelas que avaliam a edificação em vários aspectos como: situação urbanística, arquitetônica e paisagística, inadequações projetuais e de uso, simuladores computacionais utilizados para obtenção de dados, diretrizes de APO, diretrizes de reabilitação e recomendações para um melhor desempenho energético e ambiental; 
Desenvolvimento de recomendações para a elaboração de novos projetos, em que se observam o desempenho ambiental, recomendações vinculadas às questões comportamentais e de uso e de manutenção para a Rede de Hemocentros do Brasil. A partir desses dados, pode-se auxiliar a produção de manuais e possível melhoramento das normas técnicas vigentes vinculadas ao desempenho das edificações.

\section{ESTRUTURA DA DISSERTAÇÃO}

Para a elaboração da pesquisa, dividiu-se o trabalho em quatro partes. A primeira delas, trata da Arquitetura Hospitalar, em que são apresentadas suas características gerais e, em seguida, a Hemorrede e especificidades dos Hemocentros. $O$ intuito do primeiro capítulo é identificar parâmetros projetuais e práticas construtivas desse tipo de edificação já identificando aspectos técnico-construtivos que afetam diretamente a qualidade ambiental de edifícios públicos.

O segundo capítulo trata da Arquitetura Bioclimática, no qual são abordados os aspectos bioclimáticos do Brasil e as especificidades de cada uma das cidades (Brasília, Manaus e Porto Alegre). Em seguida, tem-se uma análise comparativa do clima dessas três cidades e sua interferência na arquitetura, o que possibilita identificar alguns aspectos e recomendações de boas práticas para o projeto.

O capítulo seguinte aborda conceitos da APO a fim de apresentar os procedimentos metodológicos de AAls, abrangendo desde o Retrofit até a interferência do BIM no desempenho das edificações. Sugere-se a partir dos parâmetros de cada um desses critérios alternativas e possibilidades para melhoria do desempenho das edificações assim como procedimento para a manutenção de EAS.

Por fim, são apresentados os resultados da pesquisa, com ênfase às características bioclimáticas de cada uma das unidades estudadas. Tem-se, a partir da AAls, uma série de recomendações que podem auxiliar na elaborações de manuais. Estes, por sua vez, operam como indicadores quanto às manutenções necessárias para melhor desempenho ambiental e vida útil de EAS. 


\section{EDIFICAÇÕES DE ASSISTÊNCIA À SAÚDE NO BRASIL (EAS)}

\subsection{ARQUITETURA HOSPITALAR}

Ao longo da história da arquitetura, verifica-se o surgimento de novas tipologias e soluções projetuais que possam acompanhar as mudanças da própria sociedade. Os edifícios de assistência à saúde, antes vinculados a espaços filantrópicos ou eclesiásticos, passaram a concentrar-se na cura de pacientes. Para tanto, a arquitetura desses edifícios passaram por significativas mudanças, visando, sobretudo, impedir a proliferação das doenças, infecções hospitalares e também garantir a sobrevida dos pacientes. Dotar esses ambientes de luz e ventilação naturais levou à adoção do tipo pavilhonar como melhor solução. No entanto, com o passar dos anos e novas pesquisas voltadas para esse tipo de edificação permitiram adaptações e também a concepção do edifício verticalizado.

O universo das edificações de saúde é muito complexo. Atualmente, têm-se hospitais e clínicas que atuam em apenas uma área da medicina, visando atender os pacientes com maior qualidade, além do aprimoramento das especialidades hospitalares, tendo em vista o próprio avanço tecnológico. Cada área da medicina possui especificações diferentes que devem ser obedecidas na fase de concepção do projeto conforme o programa de necessidades a que se destina. Por exemplo, os hospitais oftalmológicos precisam de consultórios sem iluminação natural direta para a realização de exames; as maternidades precisam de berçários e salas de parto; as clínicas de cirurgia plástica recebem pacientes saudáveis, e os Hemocentros abastecem todos esses hospitais sem lidar com pacientes diretamente e sim com doadores.

\subsection{HEMOCENTROS PÚBLICOS}

Os Hemocentros Públicos, constituintes do SUS ${ }^{2}$, são EAS responsáveis pela coleta, armazenamento e triagem do sangue. São conhecidos como banco de sangue, sendo que em suas instalações recebem doadores voluntários e realizam a triagem do sangue para os demais EAS do SUS, preferencialmente.

A Hemoterapia é a ciência que estuda o tratamento das doenças, pela utilização do sangue. Em 1918, ocorreu a primeira transfusão de sangue armazenado; em 1936, em Barcelona foi criado o primeiro banco de sangue e, em 1942, Landsteiner identificou o Fator $\mathrm{RH}$. Antes do período científico outras experiências ocorreram. No ano de 1492, o Papa Inocêncio VIII foi a primeira pessoa a receber transfusão de sangue, embora sem sucesso,

\footnotetext{
2 Do Sistema Único de Saúde (SUS) fazem parte os centros e postos de saúde, hospitais - incluindo os universitários, laboratórios, hemocentros (bancos de sangue), além de fundações e institutos de pesquisa, como a FIOCRUZ - Fundação Oswaldo Cruz e o Instituto Vital Brazil. Destina-se ao atendimento da saúde de toda a população brasileira gratuitamente,
} 
pois a transfusão foi feita via oral e ele faleceu. Em 1569, Andréa Cisalpini descobriu a circulação sanguínea; em 1627, Willian Harvey descreveu a circulação sanguínea, que tornou-se, mais tarde a base científica da transfusão e, em 1665, Richard Lower realizou a transfusão de sangue experimental em animais. Em 1667, Jean Baptiste Denis realizou a primeira experiência em ser humano, com sangue de carneiro. Finalmente, em 1818, James Blundell realizou a primeira transfusão com sangue humano, em mulheres com hemorragias pós-parto.

No Brasil, entre 1942 e 1944 ocorreu a criação dos bancos de sangue de Porto Alegre, Recife e da Lapa, no Rio de Janeiro. Em 1950, aconteceu o I Congresso Paulista de Hemoterapia e, no ano seguinte foi sancionada a Lei Federal n. 1.075 (BRASIL, 1950) pelo presidente Dutra, que dispõe sobre a doação voluntária de sangue; em maio do mesmo ano ocorreu o I Congresso Brasileiro de Hematologia e Hemoterapia e a fundação da SBHH Sociedade Brasileira de Hematologia e Hemoterapia (SBHH). Em 1965, o Presidente Castelo Branco sancionou a Lei Federal n. 4.701 (BRASIL, 1965), definindo o exercício da atividade hemoterápica no Brasil e as bases da Política Nacional de Sangue.

No ano de 1967, foi fundado o Colégio Brasileiro de Hematologia e Hemoterapia, entrando em vigor o decreto $n^{\circ} 60.969$ (BRASIL, 1967), que determinava as competências dos órgãos executores da atividade hemoterápica. Em seguida, o governo normatizou e deu instruções e critérios de elegibilidade e rotinas para atendimento de doadores de sangue.

No final da década de 1960, ocorreu a assinatura do Convênio de Cooperação Técnica entre o Governo de Pernambuco e a França. Em 1975, a SBHH propôs o Programa de Educação Sanitária de Doação de Sangue e, em 1976, ocorreu a discussão, em caráter sigiloso, na Secretaria de Planejamento da Presidência da República, para formulação de nova regulamentação da atividade hemoterápica. No ano de 1977, fundou-se o Centro de Hematologia e Hemoterapia de Pernambuco (HEMOPE).

Somente em 1980, a SBHH lançou a Campanha Nacional de Doação de Sangue Comunitária, com o apoio do Ministro Waldir Arcoverde, possibilitando a discussão acirrada entre o público e o privado, além da implantação do Programa Nacional do Sangue e Hemoderivados, chamado de Pró-Sangue, momento em que houve o início da implantação da rede de Hemocentros no país.

Entretanto, os Hemocentros e os estudos Hemoterápicos ganharam força somente a partir de 1981 com o reconhecimento da Síndrome da Imunodeficiência Adquirida (AIDS), nos Estados Unidos e os riscos de contaminação e transmissão de doenças via sanguínea. Ao mesmo tempo, no Brasil, ocorreu o fim da doação remunerada de sangue, reduzindo drasticamente os estoques de bolsas de sangue e o risco de contaminação passa a ser de 1: 300 mil transfusões. Em 1988, foi decretada a Lei n. 7.649 (BRASIL, 1988) que obrigava a realização de exames laboratoriais para examinar o sangue coletado, aferindo a 
presença ou não das seguintes doenças: Hepatite B, Sífilis, Doença de Chagas, Malária e AIDS.

Desde os anos 1960, houve aumento dos investimentos públicos no setor de saúde, com maior ênfase a partir dos anos 1980, com a implantação do SUS e uma política nacional de atendimento (Tabela 1 e Gráfico 1).

Tabela 1: Investimentos do orçamento público em Sangue e Homoderivados, em $\mathrm{R} \$$ milhões por ano.

\begin{tabular}{|l|c|c|c|c|c|}
\hline ANO & 1998 & 1999 & 2000 & 2001 & 2002 \\
\hline ORÇAMENTO & 15,8 & 34,7 & 41,8 & 30,9 & 44,7 \\
\hline$\%$ SAÚDE & $1,23 \%$ & $2,24 \%$ & $2,38 \%$ & $1,37 \%$ & $1,82 \%$ \\
\hline
\end{tabular}

Fonte: Ministério da Saúde Subsecretaria de Planejamento e Orçamento (2003)

No gráfico 1, o aumento no investimento público é notório, apesar de que os investimentos não ultrapassam 2\% do total investido em saúde entre 1998 e 2002.

Gráfico 1: Investimentos do orçamento público em Sangue e Homoderivados, em $\mathrm{R} \$$ milhões por ano.

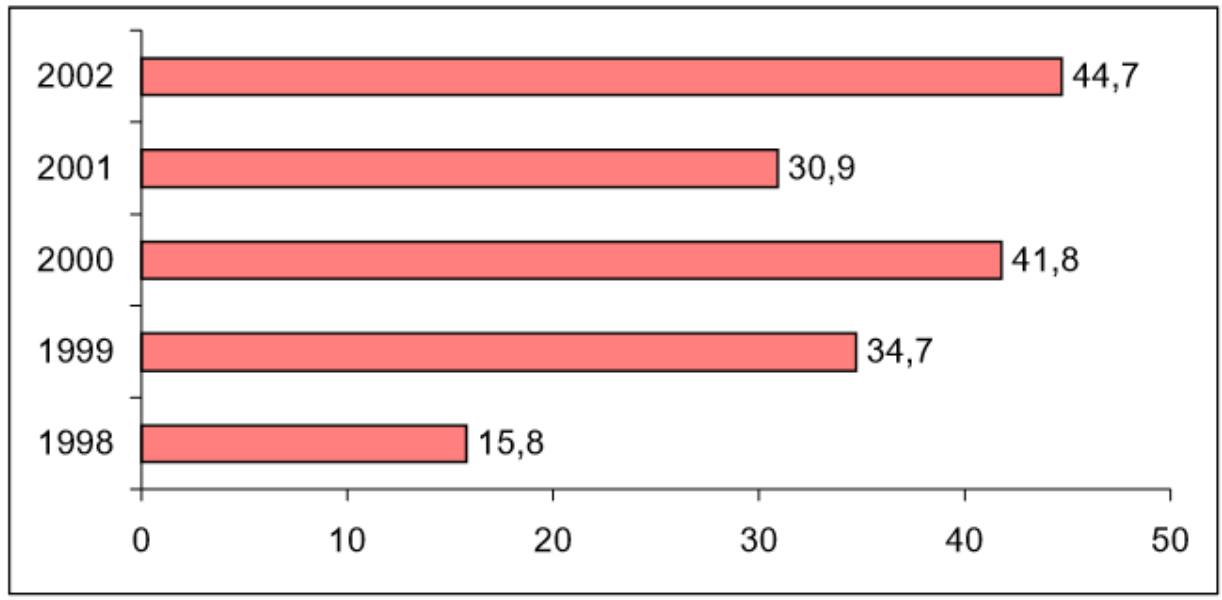

Fonte: Ministério da Saúde/Subsecretaria de Planejamento e Orçamento (2003)

Os Hemocentros são instituições públicas ou privadas que realizam atividades de hemoterapia e hematologia com o objetivo de fornecer sangue (seus componentes e hemoderivados), preferencialmente, aos hospitais da rede pública, quando se trata de Hemocentros Públicos e, preferencialmente, diversos da rede privada, quando se trata de Hemocentros Privados, além do atendimento ambulatorial das patologias relacionadas ao sangue.

Os Hemocentros Públicos podem fornecer sangue aos hospitais privados quando houver necessidade e os Hemocentros Privados podem fornecer sangue aos hospitais da rede pública quando os bancos de sangue da rede pública estiverem com estoque baixo de sangue a ponto de impossibilitar o atendimento aos pacientes com doenças do sangue e aos casos emergenciais.

Nos Hemocentros da Rede Pública, a doação de sangue é voluntária, anônima, altruísta, não remunerada e o sangue é repassado gratuitamente aos Hospitais Públicos e 
aos Pronto Socorros. Nos Hemocentros Privados, a doação de sangue é voluntária, anônima, não remunerada e o sangue é repassado de forma gratuita aos Hospitais Privados. Os Hemocentros Privados cobram o custo da coleta do sangue: os insumos utilizados, reagentes, materiais descartáveis e a mão-de-obra especializada, inclusive honorários médicos.

As comunidades médica e científica, as Sociedades Internacionais da Cruz Vermelha e do Crescente Vermelho, a Organização Mundial da Saúde (OMS), a Organização Pan-Americana da Saúde (OPAS) e outras Organizações Humanitárias não admitem e desencorajam, enfaticamente, a coleta de sangue de doadores remunerados. Em muitos países, é ilegal esse tipo de doação de sangue, mas em alguns países a doação remunerada é permitida e, em outros países, ainda existe a doação remunerada não legalizada. Pessoas que recebem remuneração para doar sangue ou que complementam sua receita "doando sangue" (leia-se vendendo o sangue), que não fazem a doação de sangue de forma espontânea e altruísta não se preocupam com a qualidade do sangue que possam estar "doando", o que pode apresentar alto risco de transmissão de doenças, haja vista que sua principal motivação é o recebimento de recompensa monetária, ou outras gratificações, e não o desejo de salvar vidas e/ou melhorar a qualidade de vida de outras pessoas.

O campo de doação de sangue no Brasil enfrenta problemas desde o início de suas atividades na década de 1940. Se, a princípio o maior entrave era conseguir sangue seguro e de qualidade, depois de estabelecidos critérios para doações, o obstáculo está no baixo número de candidatos à doação. A aptidão está relacionada à boa saúde daqueles que buscam os serviços de Hemocentros e o retorno do doador, muitas vezes, condicionado à forma como o atendimento é prestado e percebido pelo usuário. A qualidade de vida, percepção que o indivíduo tem de sua posição no contexto no qual se insere, pode influenciar a saúde e emerge como forma de enfocar a subjetividade em um contexto de exames e práticas objetivas. Falta, ainda, nas políticas públicas de saúde certa sensibilização para que mais voluntários tornem-se efetivos doadores de sangue. Uma das prerrogativas é a melhoria das condições ambientais das edificações da Hemorrede.

Condicionar uma edificação, de qualquer tipologia, com características básicas de conforto ambiental e humanização provoca efeitos benéficos em seus usuários. A resposta para este investimento é um comportamento além de mais constante, mais empático, pois ambientes confortáveis seja no âmbito das cores, da ergonomia, da temperatura, da iluminação, da ventilação tendem a ser revisitados e conservados.

O aumento e o retorno do usuário-doador é um dos principais objetivos para se requalificar um Hemocentro. Além disso, tornar o usuário-funcionário um guardião do 
ambiente de trabalho também pode ser uma das prerrogativas dos projetos de Humanização e ou Reabilitação da Hemorrede. 


\section{ARQUITETURA BIOCLIMÁTICA}

Nas últimas décadas, as cidades têm crescido com intensificação da urbanização em que interesses econômicos e a falta de cuidados em relação ao meio ambiente criam inúmeros problemas, tais como o desconforto térmico e degradação ambiental. O processo de formação de uma cidade demanda planejamento, o que envolve diversas áreas de conhecimento, pois trata-se da modificação de ambientes naturais. (ROMERO, 2013, p. 9).

O desenho dos espaços urbanos e arquitetônicos deve ser condicionado às características do meio natural, tais como topografia, revestimento do solo, latitude, objetos tridimensionais e clima. Nas palavras de Romero (2013, p. 11):

Para que a ação transformadora do meio físico seja corretamente desenvolvida, fazem-se necessárias a organização e a instrumentalização das informações sobre os elementos físicos-ambientais, em especial sobre - clima, já que este cria o cenário, expressando-se em dados de temperatura, umidade, precipitação, velocidade de direção do vento e insolação. Estes elementos sofrem desvios locais dando origem a microclima ou clima local que caracteriza o meio no qual se desenvolve a maioria das práticas.

As primeiras construções e traçados urbanos, aqueles considerados primitivos, são os mais adequados ao local, pois respeitam as características do sítio, o que expressa um profundo conhecimento do lugar, dada a adaptação do ambiente construído ao natural. A boa arquitetura reflete condições ambientais que melhor satisfaçam às exigências do conforto térmico do homem, em que o desempenho da edificação consiste na mediação entre o clima externo e o ambiente interno. Para a elaboração do partido, as condições climáticas locais devem ser consideradas, visando atender ao nível de satisfação térmica do usuário, deixando claro que o clima afeta diretamente os espaços construídos e o homem. (ROMERO, 2013, p.11).

Dentre os estudiosos sobre bioclimatismo, segundo Romero (2013), destacamse Olgyay, Givoni e Fanger. Eles tratam da relação térmica homem-meio ambiente preocupando com o edifício e sua resposta ao clima em que se inserem. Romero (2013) comenta que Olgyay (1973) sugere um roteiro para o processo de construir uma edificação estável, respaldado pelo clima, biologia, tecnologia e arquitetura. Nesse plano, está a análise dos dados bioclimáticos de uma região, avaliação biológica baseada nas sensações humanas, soluções tecnológicas para bloquear os impactos de climas adversos e aplicação no projeto de arquitetura, desses conhecimentos. Givoni (1976) trata da inter-relação entre homem, clima e arquitetura, analisando a troca de calor entre o homem e o meio ambiente e ilustra a aplicação de princípios de desenho e a seleção de materiais para adaptar a edificação ao clima seja quente-seco, quente-úmido e mediterrâneo. Já Fanger, avalia como 
os elementos do clima e as variáveis individuais afetam a percepção do conforto térmico dos indivíduos.

Os estudos bioclimáticos ganharam destaque a partir da década de 1970, devido ao contexto e aos avanços sobre a consciência ambiental a partir de conferências internacionais. A necessidade não só de substituição do combustível como também da economia de energia pela utilização de fontes menos poluentes e renováveis para a arquitetura são referências para o debate. Pesquisas e estudos vinculados às soluções arquitetônicas adaptadas a essas novas exigências que, além de serem menos agressivas ao meio ambiente, proporcionam saúde física e mental para os indivíduos.

Romero (2013) diferencia elementos e fatores em sua análise sobre o clima. Os elementos têm a qualidade de definir e fornecer os componentes do clima e os fatores, a qualidade de condicionar, determinar e dar origem ao clima. Os fatores climáticos são aqueles que condicionam, determinam e dão origem ao clima como: radiação solar, latitude, longitude, altitude, ventos e massas de água e de terra e pela distribuição de temperatura na superfície. Destaca-se a influência da radiação solar por ser responsável pela vida na terra. Os fatores climáticos locais são aqueles relacionados ao microclima, ou seja, em um ponto restrito, como: topografia, vegetação e superfície do solo. Os elementos climáticos são os que representam os valores relativos a cada tipo de clima como a temperatura, umidade do ar, precipitações e movimentos do ar.

O clima pode ser classificado pelos seguintes aspectos: a) conforme a média anual da temperatura do ar, como quente, temperado, frio e glacial; b) conforme a variação de amplitude da temperatura média do ar como continental ou moderado; c) conforme a média anual da umidade relativa do ar como muito seco, seco, úmido e muito úmido, e d) conforme a média anual de precipitação como desértico, árido, semiárido, moderadamente chuvoso e excessivamente chuvoso.

No entanto, essa classificação é criticada por alguns estudiosos já que não considera outras influências significativas além da temperatura. Para um estudo sobre bioclimatismo interessa uma classificação mais específica que demonstre as principais características do clima, verificando o espaço construído e seu entorno imediato.

A classificação de Ferreira (1965) é mais abrangente, definindo três características principais para o clima tropical, que são: quente-seco, quente-úmido e tropical de altitude. O tipo de clima é importante para que se estabeleçam estratégias bioclimáticas de projetação, visando melhor conforto ao ambiente construído.

A regulação térmica do homem ocorre por radiação, troca por condução, troca por convecção e troca por evaporação em busca de manter sua temperatura corporal em torno de $37^{\circ} \mathrm{C}$. Nos ambientes, o homem não é elemento passivo, pois além de realizar 
trocas térmicas com o meio em busca de equilíbrio, também constrói abrigos para se proteger das condições climáticas adversas.

Desde o início, o homem fazia naturalmente seu abrigo, em perfeita harmonia e adaptado ao meio. Muitas vezes, visualmente, o abrigo se confundia com o próprio ambiente natural, visto que eram incorporados à paisagem, com baixo ou quase nenhum impacto.

A arquitetura vernacular se destaca na arquitetura bioclimática por utilizar técnicas locais e o conhecimento de cada povo, aplicando produtos naturais locais e desenvolvimento de abrigos que minimizam os efeitos negativos do clima no qual a edificação está inserida, a um custo baixo e adaptado ao meio. Essas soluções possibilitam a harmonia entre homem e natureza e a associação íntima do abrigo com a terra. Pode-se perceber que o espaço construído deve manter estreito laço com o entorno, produzindo uma situação de equilíbrio ecológico autorregulado, minimizando os impactos das intervenções e do desconforto climático.

A produção de espaços deve contemplar as manifestações culturais, sociais e formas de vida da população, e compreender que o clima do local pode contribuir para as práticas sociais, protegendo o homem de situações climáticas desconfortáveis.

Para que isso aconteça é exigido do projetista conhecimentos climáticos, culturais, sociais de cada localidade, de cada microclima. É importante também recordar os ensinamentos vernaculares, e pesquisar sobre os estudos atuais e tecnológicos que garantam à edificação a melhor adaptação climática possível. Essa adaptação deve ser realizada de maneira a não consumir recursos naturais não renováveis ou que os consuma minimamente.

No momento da projetação adaptada ao clima, não se proíbe a utilização de recursos que consumam energia, água, ou que polua, em busca de amenizar situações e desconfortos climáticos extremos, mas é solicitado que o projetista apresente soluções que minimizem o uso de combustíveis fósseis, de energia elétrica entre outras fontes não renováveis.

Romero (2001, p. 15) aborda aspectos bioclimáticos para o ambiente construído e os subdivide em quatro grupos temáticos: tradição vernácula, arquitetura solar, desenho dos espaços urbanos e tratamento dos espaços exteriores. Segundo estudos de Olygay, Givoni e Fanger (ROMERO, 2001), o conforto ambiental depende das tecnologias e dos materiais empregados em sua construção e o seu desempenho perante o clima do lugar. Algumas condições intrínsecas para o conforto térmico dos ambientes construídos devem ser consideradas: interdisciplinaridade entre clima, biologia, tecnologia e arquitetura. A análise proposta pelos autores respalda-se na avaliação dos impactos biológicos a partir das sensações humanas e a aplicação de soluções tecnológicas que minimizem os aspectos adversos do clima e, por fim, o rebatimento desse diagnóstico na arquitetura. 
Para tanto, avaliar as condições climáticas do lugar é fator fundamental para uma arquitetura bioclimática. Associar os dados climáticos à análise propicia aplicar corretamente o anteparo tecnológico disponível (ROMERO, 2001). A autora ressalta que Olygay foi pioneiro na abordagem bioclimática, seguido por Givoni (1992) que avançou ao incorporar o homem nessa relação, além de abordar as influências da superfície externa dos edifícios nas variáveis climáticas.

Segundo Romero (2001, p.25): “[...] a arquitetura bioclimática é uma área relativamente nova e pouco desenvolvida, mas que tem na arquitetura vernácula, os antecedentes que servem de exemplos de respostas adequadas do homem às exigências do meio ambiente [...]". A arquitetura bioclimática se apropria desses conceitos para a promoção de novas fontes energéticas, evitando o uso de combustíveis fósseis. Há um diálogo entre os recursos naturais renováveis e a arquitetura, resultando em uma sincronia entre projeto, entorno e meio ambiente. Para Romero (2001), as condições climáticas indicam, por exemplo, o isolamento térmico, melhor posicionamento de superfícies envidraçadas e também a necessidade de proteções solares como componentes das envoltórias dos edifícios.

Percebe-se que a influência do lugar orienta a concepção de um projeto voltado ao bioclimatismo, que deve também abarcar as questões históricas e culturais locais. Segundo Asiain (1989 apud ROMERO, 2001), o enfoque bioclimático nada mais é do que compreender um determinado lugar, seus condicionantes físicos e climáticos, seus aspectos históricos, culturais e estéticos como pré-requisitos para o desenvolvimento do projeto arquitetônico. São ações que possibilitam uma nova metodologia de projeto, incluindo aspectos locais, culturais, ambientais e tecnológicos, visando a preservação ambiental e condições para o desenvolvimento sustentável das cidades.

Em grande parte das pesquisas que envolvem o ambiente hospitalar, verifica-se uma preocupação maior em discutir as problemáticas funcionais, concentradas na aplicação das normas e requisitos técnico-construtivos. No entanto, é preciso incorporar a essas discussões outros aspectos que são tão importantes quanto aqueles: a humanização do ambiente construído associada às soluções bioclimáticas. Para tanto, é indispensável conhecer os aspectos bioclimáticos das cidades em estudo. 


\section{1. $\quad$ Aspectos Bioclimáticos no Brasil}

Através da arquitetura bioclimática pode-se projetar de maneira correta e aplicar os elementos arquitetônicos com o objetivo de fornecer ao ambiente construído um grau satisfatório de conforto higrotérmico com baixo consumo de energia.

As cartas bioclimáticas associam zona de conforto térmico, clima local e estratégias de projeto indicadas para cada período do ano. Essas estratégias podem ser passivas (naturais), que não utilizam energia para seu funcionamento ou ativas (artificiais), que a utilizam.

$\mathrm{Na}$ maioria das cidades brasileiras, as estratégias para conforto térmico são artificiais como ventilação mecânica, aquecimento e refrigeração, pois durante o processo de projetação, os profissionais envolvidos não tiraram partido do clima, característica do sítio a fim de proporcionar conforto térmico para a edificação.

Vive-se, atualmente no Brasil, um momento de crise energética, onde paga-se um alto valor pelo uso da energia, e problemas com a diminuição dos recursos naturais que fornecem energia. Projetar edificações que utilizem estratégias passivas para manter a edificação na zona de conforto climático é, além de econômico, possibilitar que a vida útil e o custo de manutenção sejam baixos, sendo assim sustentáveis (Figuras 09 e 10).

Figura 5: Estratégias para resfriamento passivo

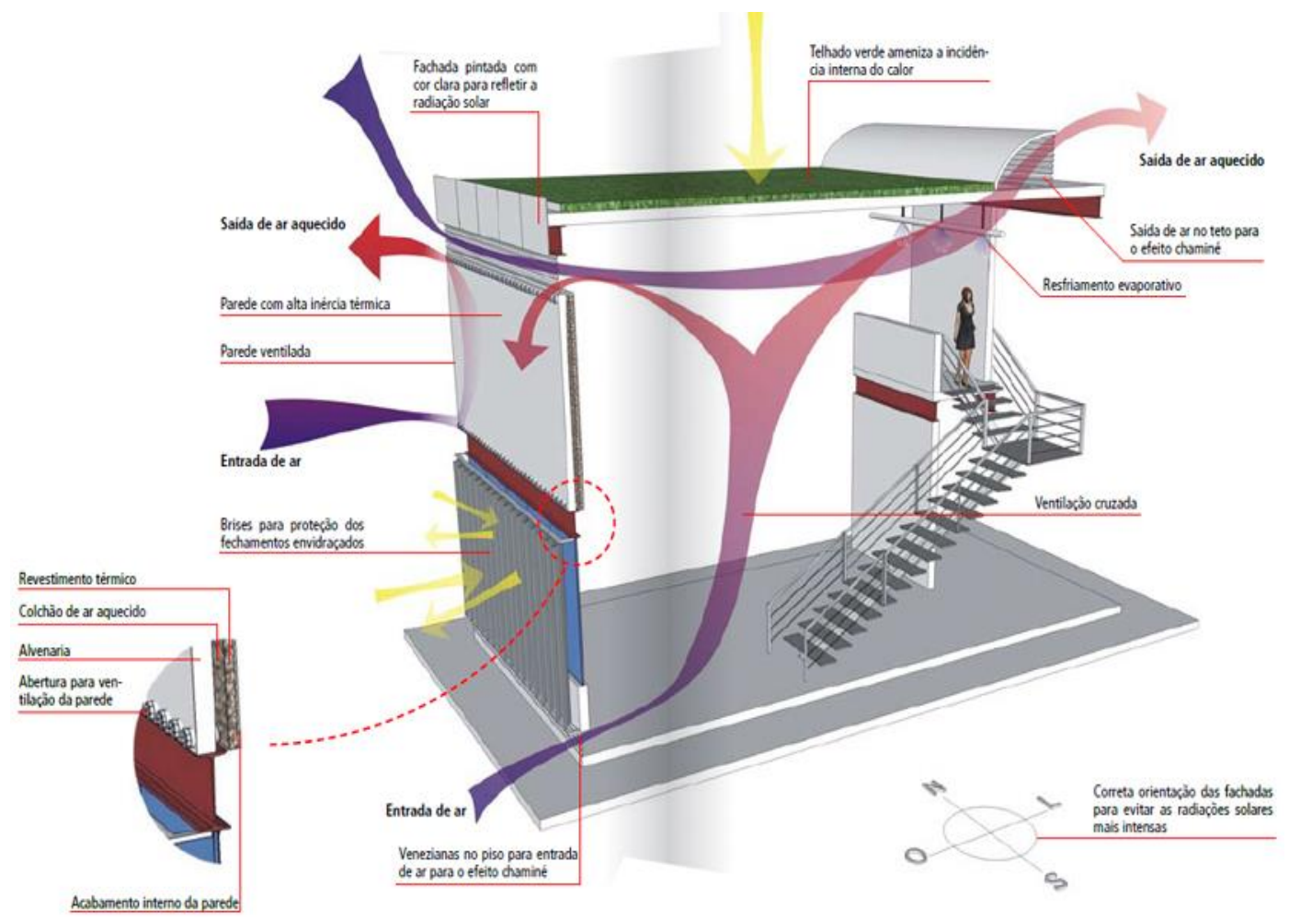

Fonte: metalica.com.br. Acesso 07 ago 2016 
Figura 6: Estratégias de conforto ambiental

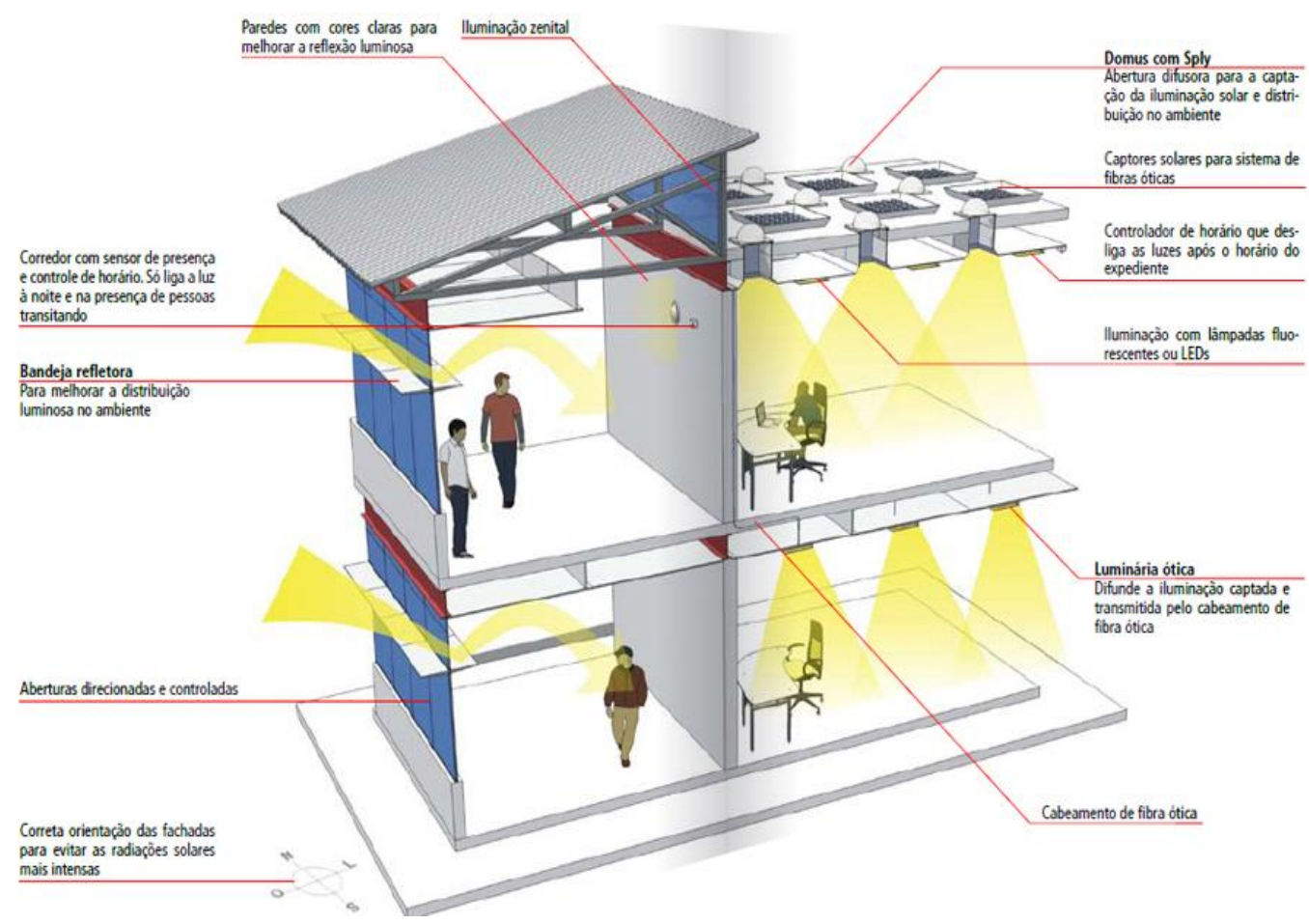

Fonte: metalica.com.br. Acesso 07 ago 2016

Para que uma edificação esteja dentro da zona de conforto térmico, a produção de calor deve ser igual à velocidade da perda. A NBR 15220 (ABNT, 2003), que trata de desempenho térmico de edificações, propõe um zoneamento bioclimático para o Brasil por nove zonas. Cada uma delas possui características de temperatura e umidade do ar diferentes (Figura 11).

Figura 7: Zoneamento Bioclimático Brasileiro

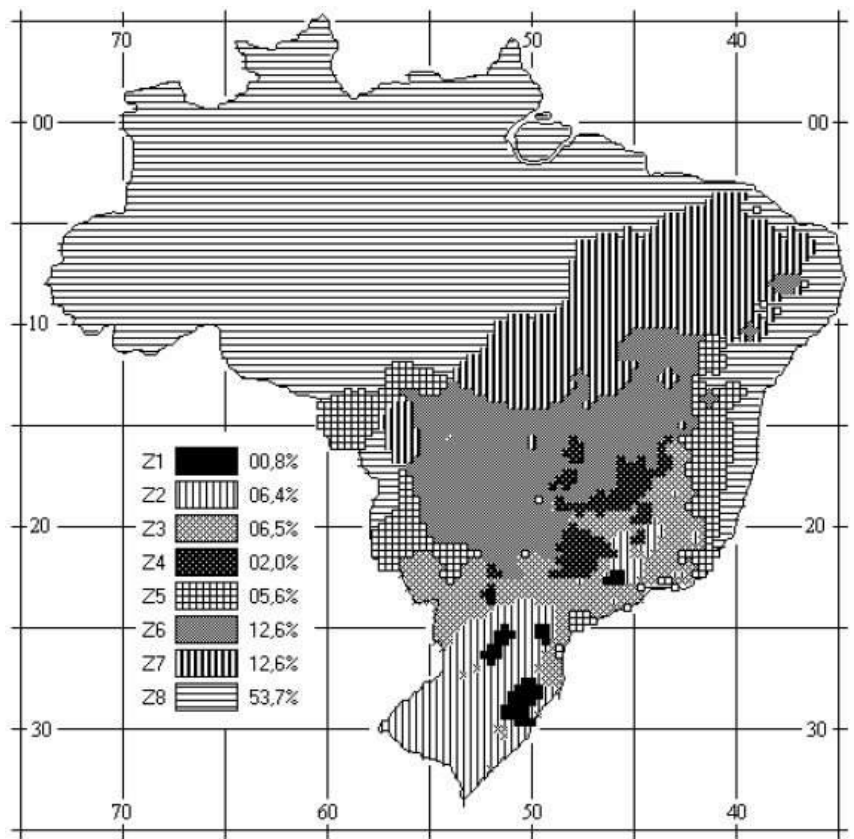

Fonte: NBR 15220 (2003). 
Além da zona de conforto, há outras zonas para as quais são indicadas estratégias para melhorar a sensação térmica. Essas recomendações baseiam-se nas cartas bioclimáticas de B. Givoni (1992), adaptadas para os climas brasileiros. São elas: aquecimento artificial (calefação), aquecimento solar, massa térmica para aquecimento, desumidificação, resfriamento evaporativo, massa térmica para resfriamento, ventilação, refrigeração artificial e umidificação do ar.

A seguir, são apresentadas as análises bioclimáticas das três cidades (Brasília, Manaus e Porto Alegre) nas quais as AAls foram implementadas e as estratégias bioclimáticas utilizadas e sugeridas para cada uma delas.

\subsubsection{Brasília}

Localizada na Latitude $15^{\circ} 52^{\prime}$ de latitude sul, a cidade de Brasília, planejada na década de 1960 para ser a capital do Brasil, possui altitude média de 1100 metros e clima classificado como Tropical de Altitude, estando na Zona Bioclimática 4 (ABNT, 2003). Este tipo de clima predomina no Brasil nos planaltos e serras do sudeste brasileiro, planalto central de Goiás e Distrito Federal e na Serra do Maracaju, em Mato Grosso do Sul.

Figura 8: Zona Bioclimática 4

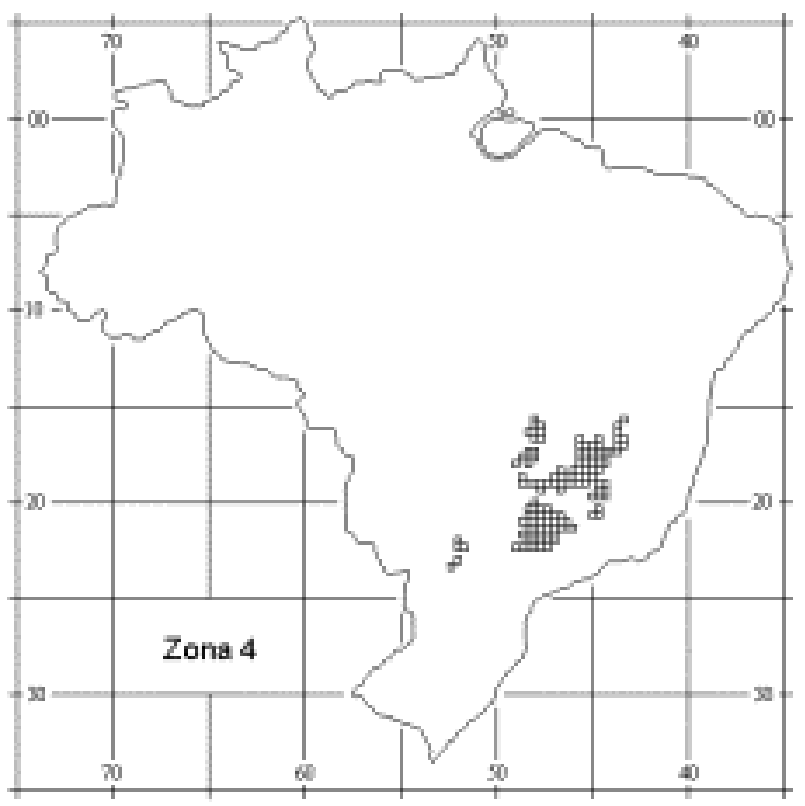

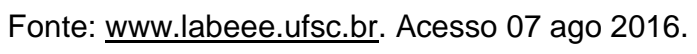

A localização de Brasília foi escolhida após a análise do sítio, considerado ameno e sem extremos climáticos. No entanto, a cidade requer cuidados especiais para 0 exercício da projetação já que apresenta exigências próprias dos climas quentes e secos e, ao mesmo tempo, dos quentes úmidos.

Se as intenções iniciais foram cuidadosas com o sítio, o que veio a seguir não acompanhou esse espírito, principalmente em relação às intervenções mais recentes. Não 
podemos negar a forte presença do céu no retrato da cidade, o verde também é generoso mesmo que seja muito mais contemplativo que convidativo. A presença do lago artificial criado por Lucio Costa ameniza um pouco a baixa umidade relativa do ar nas épocas de tempo seco.

Há duas estações marcantes (Gráfico 2), seca e chuvosa: a primeira de maio a setembro, e os meses chuvosos são outubro, novembro, dezembro, janeiro, fevereiro, março e abril.

Gráfico 2: Relação meses x índice pluviométrico de Brasília x temperatura.

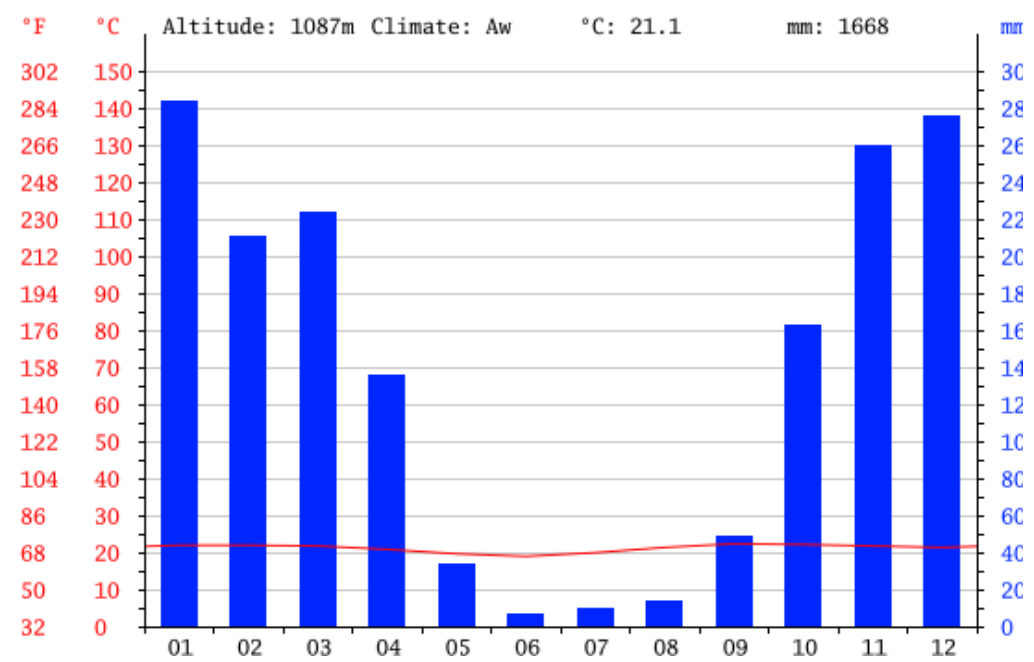

Fonte: http://pt.climate-data.org/location/852/ . Acesso em 07 ago. 2016.

Entre os meses de maio, junho e julho temos as temperaturas mais baixas do ano de aproximadamente $17^{\circ} \mathrm{C}$, e as máximas entre agosto, setembro e outubro, com as temperaturas mais altas do ano com aproximadamente $28^{\circ} \mathrm{C}$ e a temperatura média anual de $21^{\circ} \mathrm{C}$ (Gráfico 3).

Gráfico 3: Gráfico climático-relação meses x temperatura de Brasília

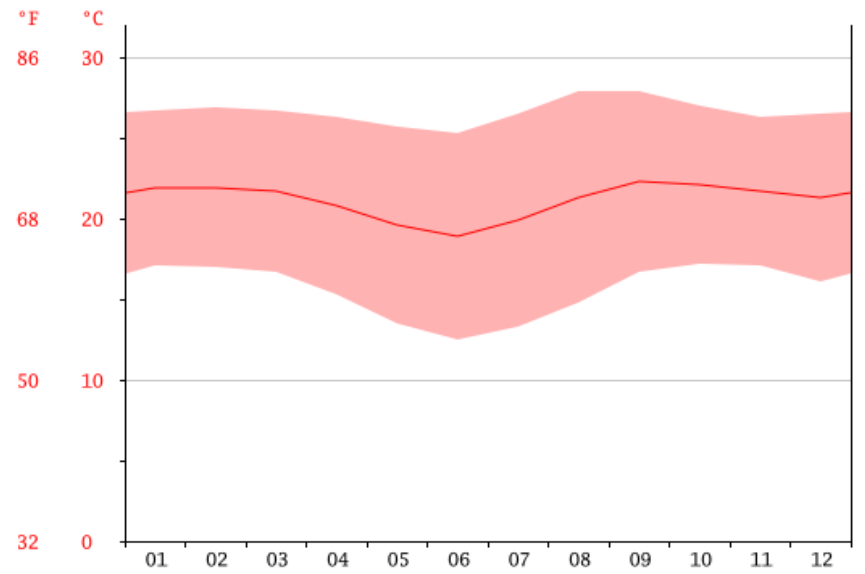

Fonte: http://pt.climate-data.org/location/852/ . Acesso em 07 ago. 2016.

$\mathrm{Na}$ Tabela 2, pode-se conferir, por meio de uma relação entre meses, precipitações e temperatura, que há duas estações climáticas na cidade de Brasília, a 
quente seca e a quente úmida e pouca variação de temperatura entre as mínimas e máximas.

Tabela 2: Relação meses $x$ temperatura x precipitação de Brasília

$\begin{array}{lrrrrrrrrrrrr}\text { month } & 1 & 2 & 3 & 4 & 5 & 6 & 7 & 8 & 9 & 10 & 11 & 12 \\ \mathrm{~mm} & 284 & 211 & 224 & 136 & 34 & 7 & 10 & 14 & 49 & 163 & 260 & 276 \\ { }^{\circ} \mathrm{C} & 21.9 & 21.9 & 21.7 & 20.8 & 19.6 & 18.9 & 19.9 & 21.3 & 22.3 & 22.1 & 21.7 & 21.3 \\ { }^{\circ} \mathrm{C} \text { (min) } & 17.1 & 17.0 & 16.7 & 15.3 & 13.5 & 12.5 & 13.3 & 14.8 & 16.7 & 17.2 & 17.1 & 16.1 \\ { }^{\circ} \mathrm{C}(\max ) & 26.7 & 26.9 & 26.7 & 26.3 & 25.7 & 25.3 & 26.5 & 27.9 & 27.9 & 27.0 & 26.3 & 26.5 \\ { }^{\circ} \mathrm{F} & 71.4 & 71.4 & 71.1 & 69.4 & 67.3 & 66.0 & 67.8 & 70.3 & 72.1 & 71.8 & 71.1 & 70.3 \\ { }^{\circ} \mathrm{F} \text { (min) } & 62.8 & 62.6 & 62.1 & 59.5 & 56.3 & 54.5 & 55.9 & 58.6 & 62.1 & 63.0 & 62.8 & 61.0 \\ { }^{\circ} \mathrm{F}(\max ) & 80.1 & 80.4 & 80.1 & 79.3 & 78.3 & 77.5 & 79.7 & 82.2 & 82.2 & 80.6 & 79.3 & 79.7\end{array}$

Fonte: http://pt.climate-data.org/location/852/ . Acesso em 07 ago. 2016.

Em 1997, em um trabalho realizado por Lamberts, Dutra e Pereira em 14 capitais brasileiras foi possível observar que Brasília possui, na sua Carta Bioclimática, vários pontos dentro da zona de conforto térmico, e dentre as cidades estudadas, se destaca como a mais confortável, segundo análise feita pelo Test Reference Year (TRY).

A partir das características bioclimáticas de Brasília sugere-se algumas recomendações bioclimáticas para a projetação que são: aberturas para ventilação de tamanhos médios com sombreamento; vedações externas, cobertura leve e isolada e paredes pesadas; no verão, resfriamento evaporativo, massa térmica para resfriamento e ventilação seletiva; no inverno, aquecimento solar e vedações internas pesadas (inércia térmica).

\subsubsection{Manaus}

Manaus está situada na região Norte do Brasil, em uma microrregião denominada Médio Amazonas (Figura 13). A $60^{\circ}$ de longitude oeste, $3^{\circ} 08^{\prime \prime}$ de latitude sul, distante $1.700 \mathrm{~km}$ em linha reta do litoral, com altitude de $92.9 \mathrm{~m}$ (HEYER, 1997). Apresenta características de clima equatorial ou tropical úmido, com temperaturas médias anuais sempre acima de $22^{\circ} \mathrm{C}$, chuvas abundantes com médias pluviométricas de $2.500 \mathrm{~mm}$, intensa radiação, elevada umidade do ar e baixas velocidades de ventos (NIMER,1979). 
Figura 9: Posição Geográfica da cidade de Manaus

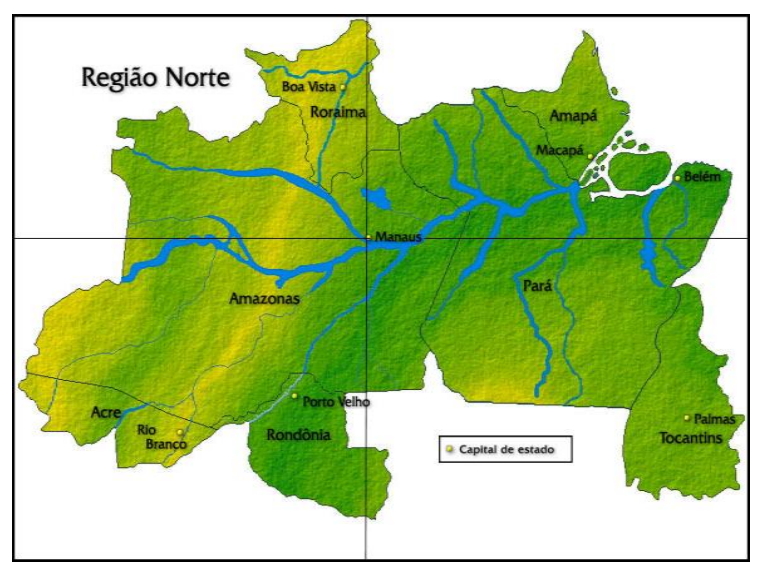

Fonte: ENTAC (2002)

Nesta região destacam-se duas estações: o maior período com precipitação pluvial tem-se o "inverno regional", compreendendo os meses de janeiro a abril e o período mais seco "verão amazônico", de junho a novembro. Nos meses de agosto, setembro e outubro tem-se o menor índice pluviométrico, cuja precipitação não ultrapassa $4 \%$ do total anual (AGUIAR, data apud BONETTI, 1999).

A capital possui altas temperaturas praticamente todo o ano, mas no inverno ocorre uma sensível baixa de temperatura, devido às frentes frias oriundas da região polar. Neste período, este fenômeno, chamado friagem, leva para a cidade forte umidade e chuvas frontais que sucedem tempo bom e queda na temperatura de junho a agosto.

De acordo com a NBR 15220 (ABNT, 2003), Manaus se encontra na Zona Bioclimática 8, em que devem ser observadas as seguintes estratégias: ventilação cruzada permanente, sombreamento de fachadas, paredes leves e refletoras, e coberturas leves e refletoras.

Apesar da carta bioclimática já ter sido adaptada ao Brasil, as condicionantes climáticas deixam a cidade fora da zona de conforto estabelecida. O conforto térmico é praticamente ausente, representando $0,24 \%$ do total de horas do ano e no desconforto causado pelo calor está presente em 99,7\% das horas, causado pelas altas temperaturas que variam de $24^{\circ} \mathrm{C}$ a $28^{\circ} \mathrm{C}$ e pelas altas taxas de umidade que, em alguns dias, chega a $100 \%$. É preciso considerar que os habitantes já estão aclimatados e toleram essas condições climáticas.

No gráfico (Gráfico 4), é possível notar que os meses de janeiro, fevereiro, março e abril são os meses com maior índice pluviométrico atingindo aproximadamente 300 $\mathrm{mm}$ no mês de março. 
Gráfico 4: relação meses x índice pluviométrico de Manaus

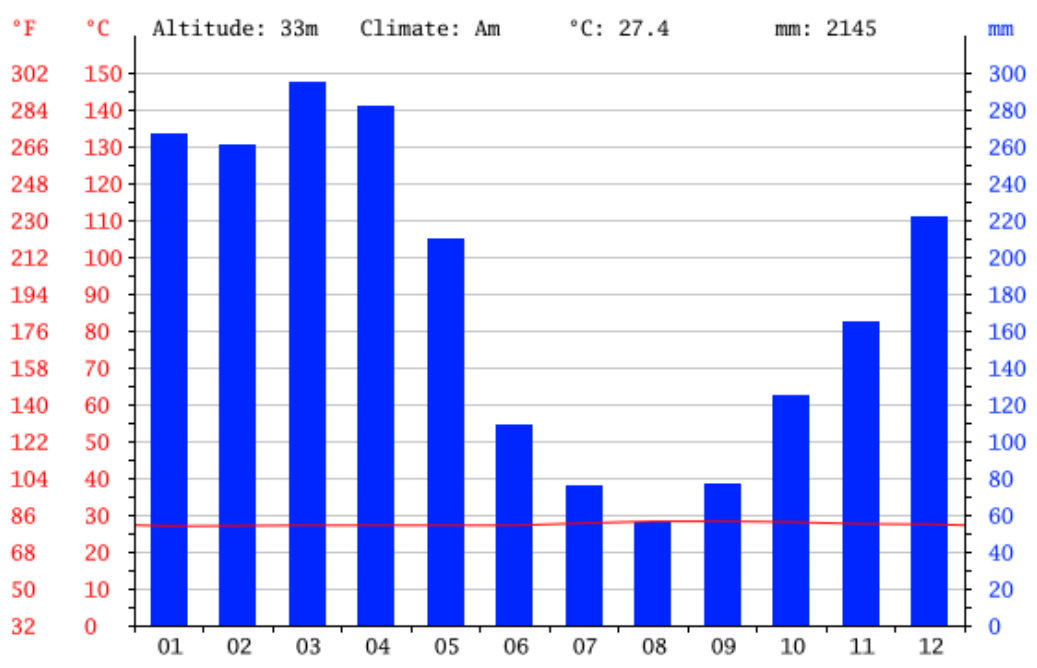

Fonte: http://pt.climate-data.org/location/1882/ . Acesso em 07 ago. 2016.

Pode-se observar que a temperatura se mantém estável praticamente todo o ano acima dos $27^{\circ} \mathrm{C}$ (Gráfico 5 e Tabela 3).

Gráfico 5: Relação meses x temperatura de Manaus

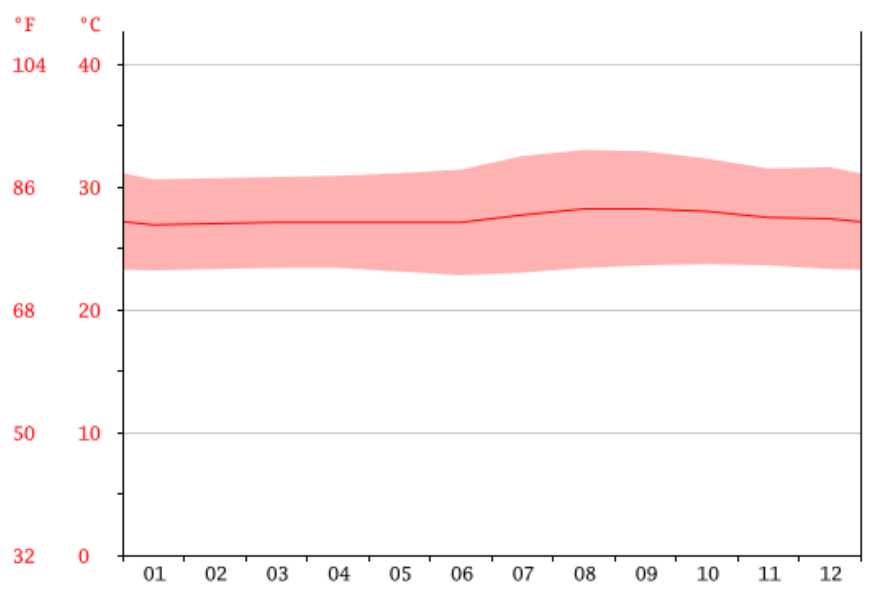

Fonte: http://pt.climate-data.org/location/1882/ . Acesso 07 ago. 2016.

Tabela 3: Relação meses $\mathrm{x}$ temperatura $\mathrm{x}$ precipitação de Manaus

$\begin{array}{lrrrrrrrrrrrr}\text { month } & 1 & 2 & 3 & 4 & 5 & 6 & 7 & 8 & 9 & 10 & 11 & 12 \\ \mathrm{~mm} & 267 & 261 & 295 & 282 & 210 & 109 & 76 & 56 & 77 & 125 & 165 & 222 \\ { }^{\circ} \mathrm{C} & 26.9 & 27.0 & 27.1 & 27.1 & 27.1 & 27.1 & 27.7 & 28.2 & 28.2 & 28.0 & 27.5 & 27.4 \\ { }^{\circ} \mathrm{C} \text { (min) } & 23.2 & 23.3 & 23.4 & 23.4 & 23.1 & 22.8 & 23.0 & 23.4 & 23.6 & 23.7 & 23.6 & 23.3 \\ { }^{\circ} \mathrm{C} \text { (max) } & 30.6 & 30.7 & 30.8 & 30.9 & 31.1 & 31.4 & 32.5 & 33.0 & 32.9 & 32.3 & 31.5 & 31.6 \\ { }^{\circ} \mathrm{F} & 80.4 & 80.6 & 80.8 & 80.8 & 80.8 & 80.8 & 81.9 & 82.8 & 82.8 & 82.4 & 81.5 & 81.3 \\ { }^{\circ} \mathrm{F} \text { (min) } & 73.8 & 73.9 & 74.1 & 74.1 & 73.6 & 73.0 & 73.4 & 74.1 & 74.5 & 74.7 & 74.5 & 73.9 \\ { }^{\circ} \mathrm{F} \text { (max) } & 87.1 & 87.3 & 87.4 & 87.6 & 88.0 & 88.5 & 90.5 & 91.4 & 91.2 & 90.1 & 88.7 & 88.9\end{array}$

Fonte: http://pt.climate-data.org/location/1882/. Acesso 07 ago. 2016 
Em Manaus, as horas de conforto são quase zero e as estratégias indicadas para proporcionar conforto são: ventilação cruzada, refrigeração artificial e sombreamento das aberturas durante todo o ano. O uso da inércia térmica associado ao sombreamento também pode ser indicado para projetos na cidade.

\subsubsection{Porto Alegre}

Porto Alegre, ao sul do país, possui um clima subtropical úmido, e com uma pluviosidade característica ao longo do ano, inclusive nos meses mais secos. Localizada na Zona Bioclimática 3 (Figura 14), onde orienta-se aberturas de tamanho médio que permitam o acesso à radiação solar para os dias de baixas temperaturas, paredes leves e refletoras, cobertura leve e isolada. Como métodos construtivos indica-se ventilação cruzada, aquecimento solar da edificação e vedações internas pesadas no inverno.

Figura 10: Zona Bioclimática 3

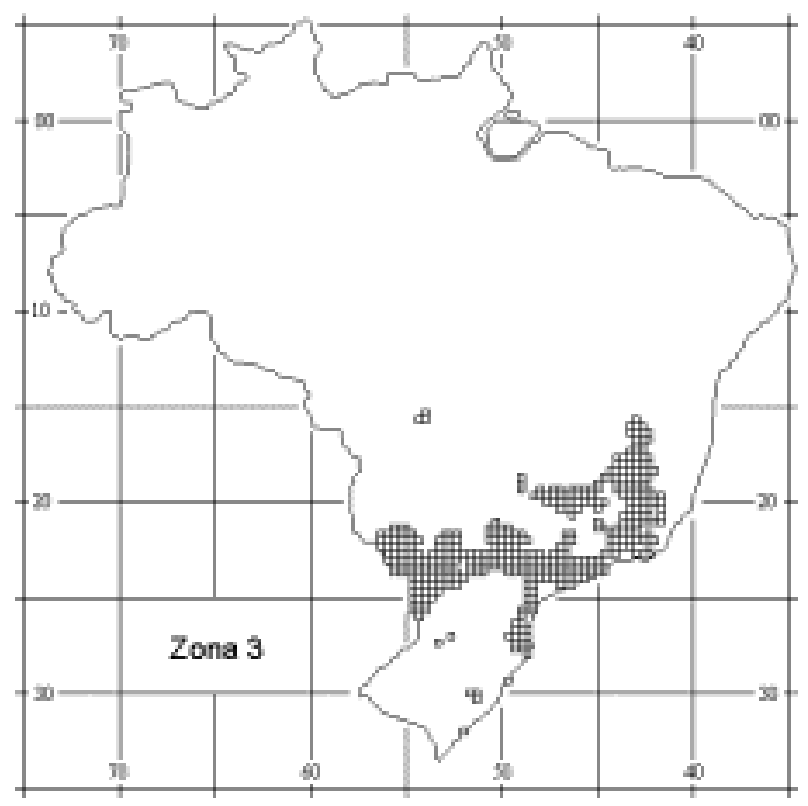

Fonte: www.labeee.ufsc.br . Acesso 07 ago 2016.

A pluviosidade média anual é $1397 \mathrm{~mm}$. No mês de abril, considerado o mês mais seco, apresenta pluviosidade de $101 \mathrm{~mm}$ e no mês de setembro, mês de maior precipitação apresenta uma média de $137 \mathrm{~mm}$. Outro fator que ajuda no aumento da umidade relativa do ar é a presença de grande massa de água do Lago Guaíba que contribui para a elevação das taxas (Gráfico 6) 
Gráfico 6: Relação meses x índice pluviométrico de Porto Alegre x temperatura.

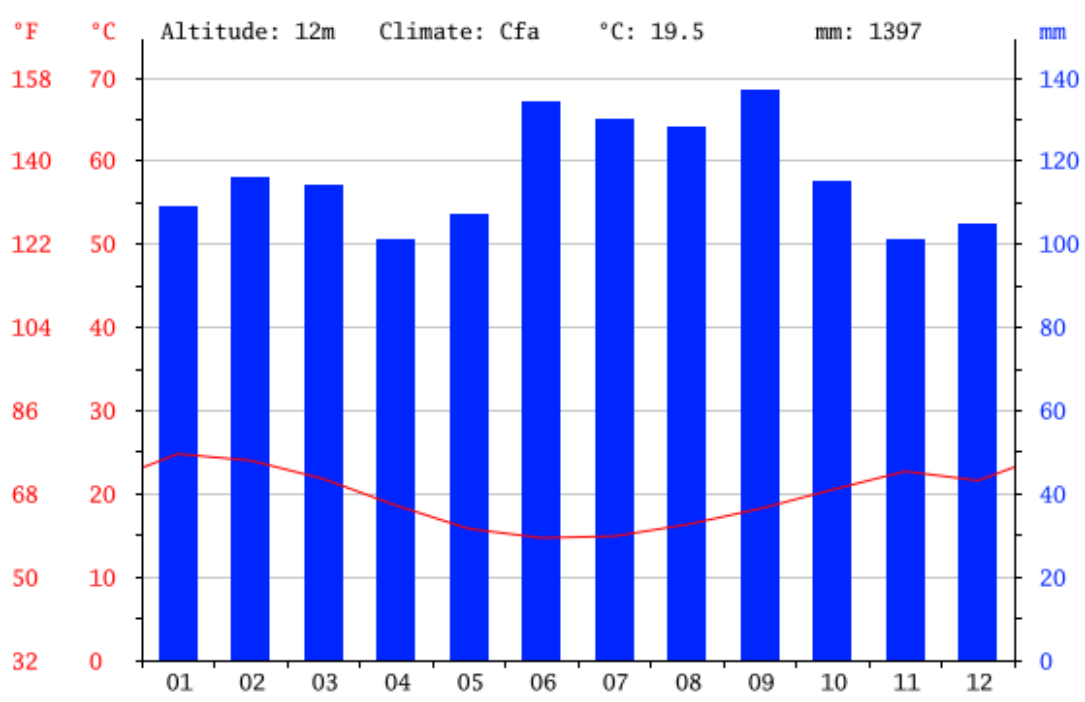

Fonte: http://pt.climate-data.org/location/3845/. Acesso em 07 ago 2016.

O mês de janeiro, considerado o mais quente do ano, a temperatura média é de $24,8^{\circ} \mathrm{C}$, e em junho, $14,7^{\circ} \mathrm{C}$, sendo esta a média mais baixa de todo o ano. (Gráfico 7 )

Gráfico 7: relação meses x temperatura de Porto Alegre

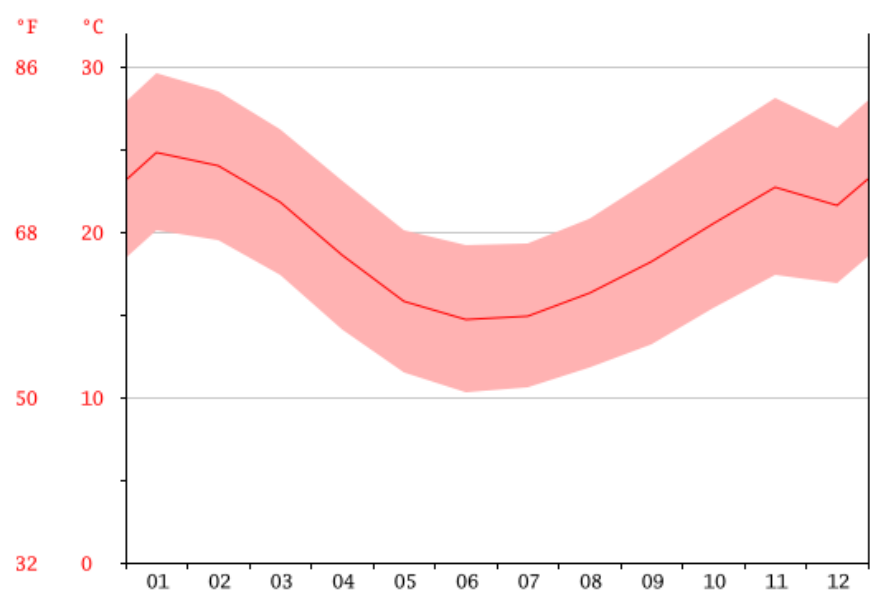

Fonte: http://pt.climate-data.org/location/3845/ em 07/08/2016

Pode-se observar que durante todo o ano há precipitações e as variações não são muito grandes. No entanto, percebe-se uma diferença de temperatura durante os meses, caracterizando uma estação fria e uma estação quente (Tabela 4). 
Tabela 4: Relação meses x temperatura x precipitação de Porto Alegre

$\begin{array}{lrrrrrrrrrrrr}\text { month } & 1 & 2 & 3 & 4 & 5 & 6 & 7 & 8 & 9 & 10 & 11 & 12 \\ \text { mm } & 109 & 116 & 114 & 101 & 107 & 134 & 130 & 128 & 137 & 115 & 101 & 105 \\ { }^{\circ} \mathrm{C} & 24.8 & 24.0 & 21.8 & 18.6 & 15.8 & 14.7 & 14.9 & 16.3 & 18.2 & 20.5 & 22.7 & 21.6 \\ { }^{\circ} \mathrm{C}(\min ) & 20.1 & 19.5 & 17.4 & 14.1 & 11.5 & 10.3 & 10.6 & 11.8 & 13.2 & 15.4 & 17.4 & 16.9 \\ { }^{\circ} \mathrm{C}(\max ) & 29.6 & 28.5 & 26.2 & 23.1 & 20.1 & 19.2 & 19.3 & 20.8 & 23.2 & 25.7 & 28.1 & 26.3 \\ { }^{\circ} \mathrm{F} & 76.6 & 75.2 & 71.2 & 65.5 & 60.4 & 58.5 & 58.8 & 61.3 & 64.8 & 68.9 & 72.9 & 70.9 \\ { }^{\circ} \mathrm{F}(\min ) & 68.2 & 67.1 & 63.3 & 57.4 & 52.7 & 50.5 & 51.1 & 53.2 & 55.8 & 59.7 & 63.3 & 62.4 \\ { }^{\circ} \mathrm{F}(\max ) & 85.3 & 83.3 & 79.2 & 73.6 & 68.2 & 66.6 & 66.7 & 69.4 & 73.8 & 78.3 & 82.6 & 79.3\end{array}$

Fonte: http://pt.climate-data.org/location/3845/ . Acesso 07 ago 2016.

\subsection{Análise Comparativa do Clima}

A análise do clima é um dos principais elementos a definir estratégias de projeto a fim de atender aos parâmetros bioclimáticos. No entanto, na maioria dos casos, o ambiente de saúde não se atenta a esses quesitos e, muitas vezes, o diagnóstico ocorre somente durante o período de uso da edificação, quando se constata a falta de qualidade ambiental e a necessidade de adequações.

Averiguar os diferentes climas em edificações de mesmas tipologias nos permite diagnosticar quais são as estratégias que podem ser adotadas para todas as áreas estudadas e quais estratégias são peculiares de cada região. Observar além das estratégias propostas pela NBR 15220 (ABNT, 2003) possibilita indicar referências projetuais com maior chance de acerto e maior eficiência.

As zonas bioclimáticas divididas pela NBR 15220 (2003) não são representadas pelo processo divisório de regiões que estamos acostumados no Brasil. As regiões Sul, Sudeste, Centro-Oeste, Norte e Nordeste não são divididas por suas características bioclimáticas exclusivamente apesar de apresentarem semelhanças. A divisão é feita por característica cultural, climática, comercial entre outros fatores. Por outro lado, as oito zonas propostas pela norma dividem o país por semelhança de temperatura, umidade, pluviosidade, comportamento das massas de vento e estações estabelecidas conforme as características climáticas.

O Brasil situa-se aproximadamente entre a linha do Equador e o Trópico de Capricórnio, apresentando seis tipos básicos de climas: equatorial, tropical úmido ou quente úmido, tropical de altitude, semiárido, tropical de atlântico e subtropical. Os Hemocentros analisados situados nas cidades de Brasília, Manaus e Porto Alegre estão em três zonas bioclimáticas diferentes, sendo elas 4,8 e 3, respectivamente.

A cidade de Manaus apresenta clima quente úmido e abrange praticamente toda a região Norte e a parte costeira do Nordeste brasileiro. Nessa cidade, o conforto térmico é praticamente ausente, representando $0,24 \%$ do total de horas do ano, e o desconforto por 
calor está presente em 99,7\% das horas, sendo causado pelas altas taxas de umidade. Estas condicionantes climáticas deixam a cidade fora da zona de conforto estabelecida pela carta bioclimática. (CARLO; LAMBERTS, 2006)

Segundo NIMER (1979), na região do Distrito Federal, raramente ocorrem temperaturas negativas. Em compensação, a elevada altitude impede temperaturas muito altas mesmo no verão. A capital federal é a cidade que possui maior número de horas de conforto térmico e se destaca como a mais confortável das capitais segundo o programa TRY. Pode-se perceber que a região bioclimática 4, na qual Brasília está inserida, é localizada somente no Centro-Oeste mas de maneira descentralizada (MACIEL, 2002).

A cidade de Porto Alegre situa-se numa região com clima subtropical e zona bioclimática 3. A localização dessa zona fica ao Sul do país e também de maneira descentralizada (Tabela 5). 
Tabela 5: Comparação entre as Zonas Bioclimáticas de Manaus, Brasília e Porto Alegre

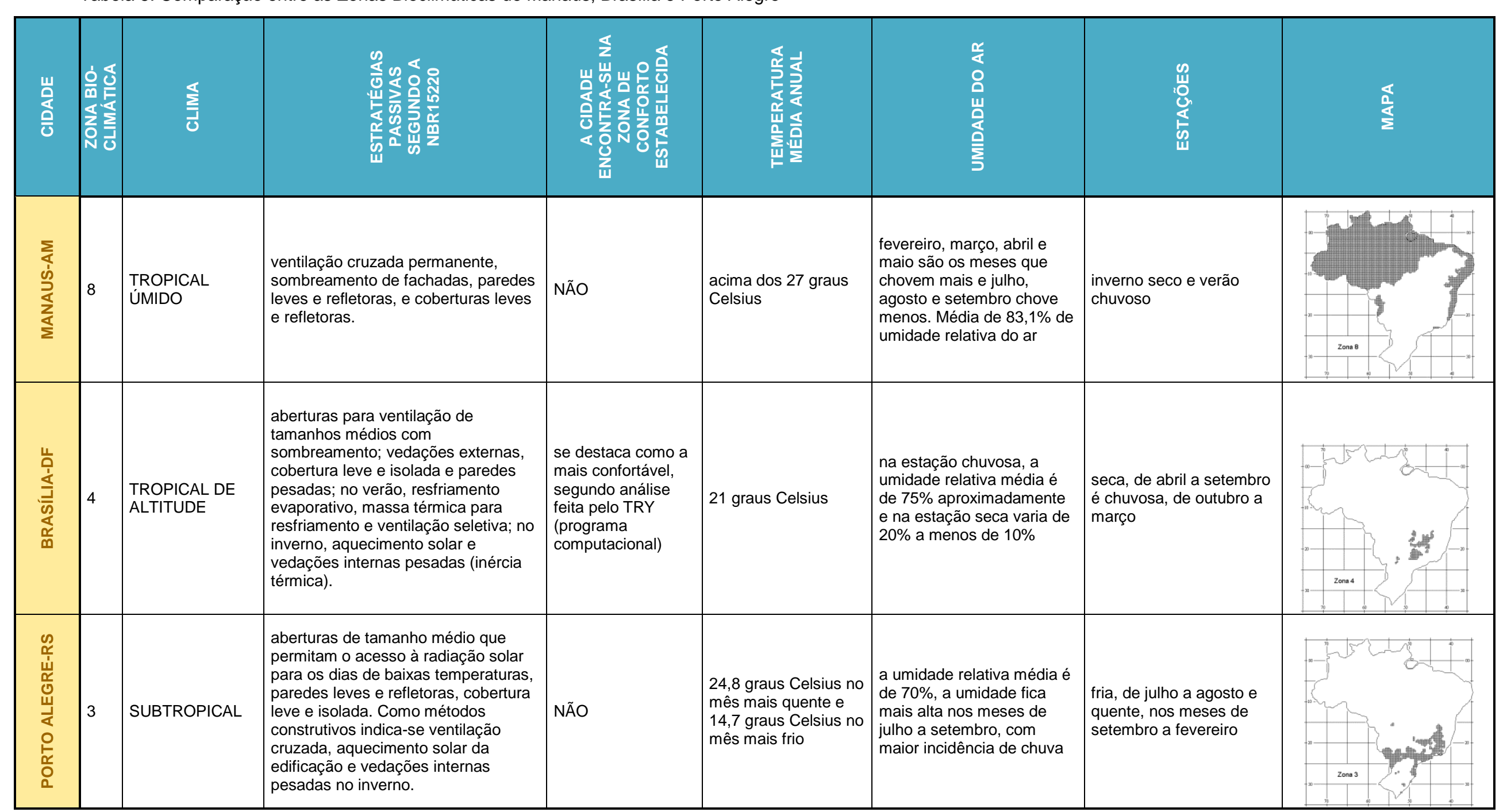

Fonte: NBR 15220 (2003). Adaptado pela autora, 2016 
As diferentes estações que se manifestam em cada local estudado podem ser observadas na tabela 6. Em Manaus, têm-se duas estações: um inverno que é pouco seco, já que a umidade extrema é uma característica marcante da região.

A altitude é a elevação vertical de um ponto qualquer da superfície terrestre em relação ao nível zero ou nível dos oceanos e podemos notar que a altitude de Manaus é relativamente baixa, somente 92 metros. A altitude de Brasília é de 1171 metros e a altitude de Porto Alegre é de apenas 3 metros.

O clima tropical de altitude, característico de Brasília, apresenta temperaturas médias entre $15^{\circ} \mathrm{C}$ e $22^{\circ} \mathrm{C}$ e amplitude térmica anual entre $7^{\circ} \mathrm{C}$ e $9^{\circ} \mathrm{C}$. O comportamento térmico é igual ao do clima subtropical; já o comportamento pluviométrico é igual ao do clima tropical. As chuvas de verão são mais intensas devido à ação da massa tropical atlântica.

A pressão atmosférica varia inversamente proporcional à altitude do local. Quanto mais alto, menor é a pressão atmosférica e mais rarefeito é o ar. Manaus e Porto Alegre, situadas próximas ao nível do mar, possuem maior pressão atmosférica que Brasília.

Em Brasília, duas estações são marcantes, quente-úmida e seca. Já em Porto Alegre, com clima subtropical úmido, as quatro estações são marcantes e representativas, outono, inverno, primavera e verão. Em Manaus, observa-se um inverno mais seco e verão chuvoso, com alta umidade do ar ao longo do ano (Tabela 6).

Tabela 6: Comparação entre os climas e características das cidades em estudo.

\begin{tabular}{|c|l|l|c|c|c|c|c|}
\hline Cidades & TIPO DE CLIMA & ESTAÇÕES & LATITUDE & LONGITUDE & $\begin{array}{c}\text { ALTITUDE } \\
(\mathbf{m})\end{array}$ & $\begin{array}{c}\text { ÁREA } \\
\left(\mathbf{K m}^{2}\right)\end{array}$ & $\begin{array}{c}\text { PRESSÃO } \\
\text { ATMOSFÉRICA }\end{array}$ \\
\hline Manaus & tropical úmido & $\begin{array}{l}\text { inverno } \\
\text { relativamente } \\
\text { seco e verão } \\
\text { chuvoso }\end{array}$ & $-03^{\circ} 06^{\prime} 07^{\prime \prime}$ & $-60^{\circ} 01^{\prime} 30^{\prime \prime}$ & 92 & 11458,5 & $1010 \mathrm{hPa}$ \\
\hline Brasília & tropical de altitude & $\begin{array}{l}\text { quente-úmida e } \\
\text { seca }\end{array}$ & $-15^{\circ} 46^{\prime} 47^{\prime \prime}$ & $-47^{\circ} 55^{\prime} 47^{\prime \prime}$ & 1171 & 5822,1 & $886,6 \mathrm{hPa}$ \\
\hline $\begin{array}{c}\text { Porto } \\
\text { Alegre }\end{array}$ & subtropical úmido & $\begin{array}{l}\text { outono, } \\
\text { inverno, } \\
\text { primavera e } \\
\text { verão }\end{array}$ & $-30^{\circ} 01^{\prime} 59^{\prime \prime}$ & $-51^{\circ} 13^{\prime} 48^{\prime \prime}$ & 3 & 496,1 & $1014 \mathrm{hPa}$ \\
\hline
\end{tabular}

FONTE: http://www.apolo11.com, www.cptec.inpe.br/cidades/ INMET. Adaptado pela Autora, 2016.

Porto Alegre, próxima de uma grande massa de água, litoral a $100 \mathrm{~km}$ a leste e serra a noroeste, possui uma umidade relativa do ar na maior parte do ano. Associados à alta temperatura e à baixa velocidade do ar, fatores que contribuem para uma sensação de desconforto térmico acentuado durante o verão (Tabela 7). Já no inverno, a umidade alta do ar contribui com a condensação em superfícies internas das edificações como uma das reclamações frequentes dos usuários (GRIGOLLETI, 2007).

Brasília apresenta média mínima anual de umidade relativa do ar de 49\%, devido ao cálculo mediano entre a estação chuvosa e a seca. Nas estações secas, a umidade relativa média pode variar entre 10 a 18\%, caracterizando um extremo desconforto para os moradores que sofrem com problemas respiratórios, de pele e visão. 
Manaus é a cidade que possui maior umidade do ar em todo ano até mesmo no mês mais seco, com $77 \%$ de umidade relativa mínima média (Tabela 7). O excesso de água na atmosfera também causa desconforto à população que sente dificuldade em liberar calor através da transpiração. A estratégia mais viável para solucionar esse problema é incentivar a ventilação e o sombreamento nos projetos.

Tabela 7: Comparação da umidade do ar nas cidades em estudo.

\begin{tabular}{|c|c|c|c|c|c|}
\hline Cidade & $\begin{array}{c}\text { Média Anual de } \\
\text { Umidade Relativa do } \\
\text { Ar }\end{array}$ & $\begin{array}{c}\text { Média Máximas de } \\
\text { Umidade Relativa }\end{array}$ & $\begin{array}{c}\text { Mês de } \\
\text { Máxima } \\
\text { Umidade }\end{array}$ & $\begin{array}{c}\text { Médias de } \\
\text { Mínimas de } \\
\text { Umidade Relativa }\end{array}$ & $\begin{array}{c}\text { Mês de Mínima } \\
\text { Umidade }\end{array}$ \\
\hline Manaus & $83,10 \%$ & $88 \%$ & março & $77 \%$ & $\begin{array}{c}\text { agosto e } \\
\text { setembro }\end{array}$ \\
\hline Brasília & $68 \%$ & $79 \%$ & dezembro & $49 \%$ & agosto \\
\hline $\begin{array}{c}\text { Porto } \\
\text { Alegre }\end{array}$ & $76 \%$ & $82 \%$ & junho & $71 \%$ & maio e julho \\
\hline
\end{tabular}

Fonte: INMET, 2016. Adaptado pela Autora, 2016.

Em Porto Alegre, pode-se observar que há amplitude de temperatura durante o ano, mas isso ocorre também durante o dia com variações de aproximadamente $10^{\circ} \mathrm{C}$, obrigando os habitantes a utilizarem roupas para se adequarem às oscilações de temperatura (GRIGOLLETI, 2007).

Manaus se destaca como a cidade mais quente (Tabela 8), nas análises de temperaturas médias, máximas, máxima absoluta e mínima média. Estimular o resfriamento evaporativo, sombras e materiais que tenham inércia térmica elevada são opções para tentar impedir que o calor penetre nas edificações, estimulando a movimentação do ar.

Brasília encontra-se entre as cidades estudadas como aquela que possui menor variação térmica e com temperaturas médias mais agradáveis.

Tabela 8: Comparação da temperatura entre as cidades estudadas.

\begin{tabular}{|c|c|c|c|c|c|c|c|}
\hline Cidade & $\begin{array}{l}\text { Temperatura } \\
\text { Média Anual }\end{array}$ & $\begin{array}{l}\text { Temperatura } \\
\text { Máxima } \\
\text { Média }\end{array}$ & $\begin{array}{l}\text { Temperatura } \\
\text { Máxima } \\
\text { Absoluta }\end{array}$ & $\begin{array}{l}\text { Temperatura } \\
\text { Mínima } \\
\text { Média }\end{array}$ & $\begin{array}{c}\text { Temperatura } \\
\text { Mínima } \\
\text { Absoluta }\end{array}$ & $\begin{array}{l}\text { Mês de } \\
\text { Temperatura } \\
\text { Mais Alta }\end{array}$ & $\begin{array}{c}\text { Mês de } \\
\text { Temperatura } \\
\text { Mais Baixa }\end{array}$ \\
\hline Manaus & $26,7^{\circ} \mathrm{C}$ & $31,4^{\circ} \mathrm{C}$ & $39^{\circ} \mathrm{C}$ & $23,3^{\circ} \mathrm{C}$ & $12,1^{\circ} \mathrm{C}$ & SETEMBRO & JULHO \\
\hline Brasília & $21,2^{\circ} \mathrm{C}$ & $26,6^{\circ} \mathrm{C}$ & $28,3^{\circ} \mathrm{C}$ & $16,1^{\circ} \mathrm{C}$ & $12,9^{\circ} \mathrm{C}$ & SETEMBRO & JULHO \\
\hline $\begin{array}{l}\text { Porto } \\
\text { Alegre }\end{array}$ & $19,5^{\circ} \mathrm{C}$ & $24,8^{\circ} \mathrm{C}$ & $39,2^{\circ} \mathrm{C}$ & $15,6^{\circ} \mathrm{C}$ & $\begin{array}{c}0,2^{\circ} \mathrm{C} \\
\text { negativo }\end{array}$ & FEVEREIRO & JULHO \\
\hline
\end{tabular}

Fonte: INMET, 2016. Adaptado pela Autora, 2016.

A cidade com maior índice pluviométrico é a cidade de Manaus. O mês com menor precipitação é o mês de agosto com aproximadamente 47,3 mm (Tabela 9). Este valor é cinco vezes maior que o valor registrado para Brasília no mês de estiagem.

Porto Alegre, apesar de possuir a menor quantidade de dias com precipitações, a menor quantidade de precipitação por ano e menor precipitação nos dias de maiores precipitações, apresenta valor de $90 \mathrm{~mm}$ no mês com menor precipitação. Quase o dobro da quantidade de chuva registrada em Manaus, a cidade mais úmida e com maior índice pluviométrico das estudadas. Sendo assim, observa-se que Porto Alegre é uma cidade com 
umidade relativa e pluviosidade média durante todo 0 ano, inclusive nos meses considerados com menores índices.

A cidade que mais sofre com a seca é a cidade de Brasília, sendo que possui maior horas de sol por ano registrado pelo INMET (2016).

Tabela 9: Comparação entre índices pluviométricos nas cidades analisadas.

\begin{tabular}{|c|c|c|c|c|c|c|c|}
\hline Cidade & $\begin{array}{c}\text { Dias Com } \\
\text { Precipitação } \\
\text { (Ano) }\end{array}$ & $\begin{array}{c}\text { Precipitaç } \\
\text { ão Por } \\
\text { Ano (Mm) }\end{array}$ & $\begin{array}{c}\text { Mês Com } \\
\text { Maior } \\
\text { Precipitação }\end{array}$ & $\begin{array}{c}\text { Maior } \\
\text { Precipitação } \\
\text { (Mm) }\end{array}$ & $\begin{array}{c}\text { Mês Com } \\
\text { Menor } \\
\text { Precipitação }\end{array}$ & $\begin{array}{c}\text { Menor } \\
\text { Precipitaç } \\
\text { ão (Mm) }\end{array}$ & $\begin{array}{c}\text { Média Horas } \\
\text { De Sol } \\
\text { (Horas/Ano) }\end{array}$ \\
\hline Manaus & 160 & 2307,4 & MARÇO & 335,4 & AGOSTO & 47,3 & 1828,5 \\
\hline Brasília & 111 & 1540,6 & JANEIRO & 247,4 & JUNHO & 8,7 & 2363 \\
\hline Porto Alegre & 101 & 1320,2 & SETEMBRO & 142,2 & MAIO & 90 & 2244,8 \\
\hline
\end{tabular}

Fonte: INMET (2016). Adaptado pela Autora, 2016.

A partir da comparação entre as características climáticas das três cidades em estudo, é possível perceber que as estratégias projetuais podem ser as mesmas para o país inteiro quando referem-se a projetos de arquitetura de mesma tipologia, como o caso dos Hemocentros, pois se baseiam em programas de necessidades padrão, entretanto ignoram as características climáticas locais deixando a edificação com baixo desempenho em relação ao conforto térmico, comprometendo sua qualidade ambiental. 


\section{AVALIAÇÃO PÓS-OCUPAÇÃO (APO)}

A APO integra um dos itens da AAl juntamente com Retrofit e Etiquetagem de Eficiência Energética em edifícios. O intuito de aplicar uma APO é promover uma intervenção que propicie a melhoria da qualidade de vida, de trabalho, de um determinado ambiente e organizar informações por meio de banco de dados, possibilitando um conhecimento sistematizado sobre o ambiente e as relações ambiente-comportamento.

O objeto do estudo da APO não trata especificamente do partido arquitetônico, da estética ou do gosto pessoal do avaliador, o objeto é o uso, a operação e a manutenção do ambiente construído, sendo um dos elementos de avaliação do desempenho das edificações.

Hoje, a APO mostra-se muito além de novo um campo de atividade profissional para arquitetos, urbanistas, psicólogos, engenheiros, gestores entre outros, porque se trata de um exercício multidisciplinar, agregando várias áreas de conhecimento. Segundo Ornstein e Roméro (1992, p. 22), a APO "[...] é um dos mecanismos mais eficientes de retroalimentação de projetos semelhantes e de controle global do ambiente construído no decorrer da vida útil."

As pesquisas avaliativas nas ciências sociais objetivam coletar, analisar e interpretar informações para otimizar as condições sociais e podem haver dois tipos de avaliações do ambiente construído: a avaliação técnica e a avaliação do ponto de vista do usuário. $O$ objetivo dessa avaliação é configurar uma avaliação global do edifício.

Poucas são as pesquisas existentes voltadas para a fase de uso, operação e manutenção do edifício, o que faz com que a vida útil dessas edificações seja reduzida pela ausência de uma análise preventiva, repetindo falhas em projetos semelhantes.

O desconhecimento na fase do uso é muito mais recorrente nos países subdesenvolvidos como apontou Bonin (1988, p. 3).

Na maioria dos casos, a origem dos problemas de manutenção localiza-se
em outras atividades que, em uma análise superficial, podem ser
considerados desconexas com as atividades de manutenção, pela distância
no tempo em que ocorrem ou pela quase total ausência de contato entre os
responsáveis por sua localização. É praticamente impossível que se consiga
obter níveis de qualidade ambiental adequados dentro dos limites de custo
aceitáveis no edifício construído, a menos que se consiga maior integração
e comunicação entre os diversos agentes intervenientes no processo
produtivo da edificação.

Grande parte dos problemas detectados no ambiente construído, notadamente na fase de uso do edifício, é proveniente da fase anterior, ou seja, da fase de produção do edifício, da etapa do projeto. As recomendações feitas pela APO têm inicialmente o objetivo de minimizar ou corrigir problemas detectados no próprio ambiente construído, com o estabelecimento de programas de manutenção e conscientização do usuário, da 
necessidade de alteração comportamental, buscando a conservação do patrimônio. Um dos objetivos é utilizar os resultados para retroalimentar a produção de ambientes semelhantes, detectando patologias e determinando terapias no decorrer do processo de produção e de uso, por meio da participação de todos os agentes envolvidos na tomada de decisões.

Os agentes que determinam o controle de qualidade no processo de produção e uso do edifício são planejadores e promotores, projetistas, fabricantes de materiais, construtores e empreiteiros, clientes públicos ou privados, e usuários. O resultado da APO pode ser vista como positivo ou negativo para cada um desses agentes, pois avaliar é fazer julgamentos, e o resultado da APO pode apontar interesses e significados diferenciados para as pessoas desses grupos distintos.

A APO se caracteriza pela avaliação do edifício pelo desempenho da edificação e da análise comportamental dos usuários. Teve seu surgimento datado após a Segunda Guerra Mundial durante as reconstruções dos edifícios públicos e residenciais, mas bastante focado no segundo item.

Nos Estados Unidos, surgiu muito ligada a um pensamento baseado na psicologia ambiental. Hall (1999) com a ideia de que o homem se distingue dos demais animais pelo fato de ter desenvolvido prolongamentos de seu organismo e pelo uso e apropriação do ambiente construído. Os países subdesenvolvidos encontram-se em um processo de aprimoramento desses estudos avaliativos e, consequentemente, a adoção de soluções mais sustentáveis para os edifícios públicos ainda é incipiente ao contrário de países desenvolvidos que as adotam.

No Brasil, a APO encontra-se em estágio avançado de desenvolvimento tecnológico, mas distante de ser utilizada por uma sociedade no qual verificamos tantos abusos de poder como a nossa. Podemos dizer que estamos de 30 a 40 anos defasados em relação ao estágio dos países desenvolvidos, conforme relatam Ornstein e Roméro (1992). No entanto, não há no país homogeneidade nem sistematização no controle de qualidade do ambiente construído. As normas da Associação Brasileira de Normas Técnicas (ABNT), códigos de edificação, Legislação de Segurança e Medicina do Trabalho, entre outros, são documentos importantes, porém contraditórios entre si na especificação de um mesmo serviço, sem parâmetros confiáveis. Soma-se a esse aspecto de que há poucos dados e informações acerca do nível de satisfação dos usuários.

Ao criar um espaço, modela-se um homem e as cidades estão modelando diversos tipos de comportamentos devido à grande diversidade de espaços para se viver, trabalhar e produzir, entre outros. O território tem papel determinante na formação e na definição desses comportamentos humanos e está diretamente ligado à hierarquia no qual o mais forte dominante tem um espaço maior e acesso ao território do mais fraco dominado. 
De acordo com Hall (1999), há uma relação entre as características do espaço de caracteres físicos e a personalidade do indivíduo que habita esse espaço. Alguns aspectos do espaço de caracteres fixos não são visíveis até que se observe o comportamento humano.

O mobiliário é um exemplo de caractere semifixo do espaço. Alguns layouts tendem a manter as pessoas separadas, outros as unem (HALL, 1999, p. 134). Há relação entre a posição em que se senta numa mesa e o estabelecimento de conversações, por exemplo, a posição em esquina, e frente a frente são mais favoráveis à conversa do que lado a lado. $O$ autor afirma que as áreas utilizadas alteram o comportamento humano, as quais podem ser benéfica, neutra ou maléfica. Há grande necessidade de se avaliar o ambiente vivido em busca de melhorias não só comportamentais como também para uma análise, custo de manutenção dessas edificações que podem ser muito dispendiosas e inviáveis.

Nos países desenvolvidos, os produtos passam por um rigoroso controle de qualidade, inclusive o ambiente construído. Sendo assim, os produtos colocados no mercado passam por avaliações sistemáticas, tendo o usuário final/consumidor como aquele ator que detecta os eventuais problemas no decorrer da vida útil. Nos países subdesenvolvidos, temos o processo contrário, uma repetição de produtos sem controle de qualidade sem avaliações sistemáticas de desempenho, o que compromete tanto sua qualidade quanto sua vida útil.

A APO é uma metodologia que pretende avaliar elementos técnicos, econômicos, funcionais, estéticos, e comportamentais reunindo a opinião de projetistas e usuários. Quanto à análise técnico-construtiva, destacam-se os aspectos térmico, luminoso, sonoro e ambiental. A APO permite a aferição das condições ambientais e a coleta de dados possibilita contribui para melhorar a fase de planejamento e produção da construção civil.

Os problemas detectados podem ser solucionados pela implantação de programas de manutenção e conscientização dos usuários, nas necessidades de alterações comportamentais, buscando obter a conservação da edificação seja ela pública ou privada.

A APO apresenta-se como importante instrumento de análise das condições ambientais de edifícios e permite a criação de um banco de dados, em que conste a avaliação comportamental e técnica de um determinado ambiente construído. Os projetos semelhantes avaliados por APO fornecem uma série de informações que auxiliam na elaboração de recomendações e considerações para novos edifícios, otimizando o desenvolvimento de projetos futuros, através da detecção de patologias e a proposição de tratamentos durante o processo de produção e uso do ambiente construído com participação intensa dos agentes envolvidos nas tomadas de decisões. 
O diagnóstico da APO permite traçar diretrizes de melhoria da eficiência energética da envoltória do edifício e também na diminuição do consumo energético. A aplicação prática dessas proposições ocorre pelo Retrofit, que são pesquisas e intervenções de soluções técnico-construtivas e materiais visando o conforto ambiental e cumprimento dos requisitos das normas de etiquetagem.

O ambiente construído também pode ser avaliado pelo Diagnóstico Energético e Retrofit. Segundo Romero (2013, p. 3), corresponde a "[...] quaisquer medidas de melhoria e elevação de desempenho de equipamentos e sistemas de edifícios existentes". Sua aplicação está vinculada aos diagnósticos dos aspectos energéticos da APO, tendo em vista a intervenção prática no edifício analisado.

A partir do momento que os problemas são identificados, é possível apresentar um conjunto de soluções ou alterações que possibilitem sua reabilitação. Com isso, abrange-se a interação com o meio ambiente de forma mais positiva à medida que há a diminuição dos impactos causados.

Avaliar o desempenho técnico, em que se destaca o conforto ambiental e a eficiência energética, aliado à percepção dos usuários em ambientes hospitalares apresenta-se como importante ferramenta de aprimoramento da qualidade funcional e também terapêutica do espaço. Considerando-se a percepção do usuário e a melhoria do desempenho técnico-funcional, também é possível qualificar o espaço com atributos e aspectos bioclimáticos.

No Brasil, os primeiros estudos de APO foram desenvolvidos junto ao Departamento de Tecnologia da Arquitetura da Faculdade de Arquitetura e Urbanismo da Universidade de São Paulo (FAUUSP) desde 1984 até os dias atuais. Nesse período, as avaliações têm sido predominantemente de habitações de interesse social, edifícios institucionais como escolas e hospitais, edifícios de escritórios e de áreas livres e parques. Esse desenvolvimento contínuo e intenso de pesquisas possibilitou o aperfeiçoamento da metodologia e adequação à realidade brasileira.

No Brasil, a APO é proposta uma reutilização dos três níveis propostos em seis. Três deles são realizados por pesquisadores e os outros três realizados são as APOs propriamente ditas, considerando o ponto de vista dos pesquisadores e dos usuários.

A avaliação de nível 1 se dedica aos aspectos construtivos, funcionais e de conforto ambiental e é realizada em 20 dias. A avaliação de nível 2 se dedica aos aspectos construtivos funcionais e de conforto ambiental com a realização de diagnósticos e recomendações e seu período é de 30 dias. A de nível 3, realiza diagnósticos, recomendações e especificações técnicas, é realizada em 40 dias.

APO de nível 4, a que trabalha com o nível 2 de avaliação física mais aspectos comportamentais, sendo realizada em 60 dias. A de nível 5, trabalha com a avaliação do 
nível 3 mais os aspectos comportamentais com recomendações e especificações técnicas para realização dos serviços propostos (caderno de encargos). A APO de nível 6, trabalha com a APO de nível 2 mais acompanhamentos das intervenções e diretrizes para o projeto, construção, uso, operação, e manutenção, tendo prazo aberto.

Os níveis sugeridos não são rígidos, mas pretendem servir como referência e observando o nível de profundidade de cada um e o da APO de forma específica, conforme relatam os pesquisadores (ORSNTEIN E ROMÉRO, 1992, p.42):

Propor recomendações sobre problemas técnico-construtivos, funcionais e comportamentais para o objeto de estudo;

Envolver projetistas, clientes e usuários no próprio processo de avaliação e de decisão, sejam elas de caráter físico ou organizacionais;

Conscientizar os principais agentes envolvidos no uso, operação e manutenção do ambiente objeto de avaliação, no sentido da conservação e otimização do desempenho do patrimônio imóvel, pois este fator está associado ao bem-estar e à produtividade dos ocupantes;

Controlar a qualidade do ambiente construído no decorrer de seu uso, minimizando custos de manutenção e de intervenções físicas propostas;

Desenvolver manuais de manutenção e operação para ambientes construídos em uso;

Desenvolver plano diretor de 'rearranjo', flexibilidade e/ou expansão dos espaços de ambientes construídos já em uso, para maior adequação destes a funções diferenciadas e a avanços tecnológicos na área de comunicação e de informática;

Desenvolver manuais/diretrizes de projeto, critérios, padrões e normas para projetos futuros de ambientes construídos semelhantes.

Os condicionantes dessa área de pesquisa e de consultoria são essencialmente os seguintes (Rossi, Freeman, 1989, p. 391-392):

Participação ainda reduzida dos usuários no processo de avaliação, e tomadas de decisão decorrentes;

Comunicação algumas vezes difícil e pouco receptiva dos usuários para com os avaliadores, não havendo critérios pré-estabelecidos que orientem essa comunicação;

Comunicação difícil e, por vezes, truncada dos avaliadores com projetistas e clientes, prejudicando a confiabilidade dos resultados;

Qualidade precária das informações obtidas junto aos usuários, decorrente, muitas vezes, de pouco envolvimento destes no processo de avaliação ou da pouca familiaridade de alguns pesquisadores com procedimentos estatísticos e técnicas de pesquisa em 'ambientes e comportamento' adequados a APO;

A dificuldade quanto à imparcialidade do avaliador no processo;

Produto final, por vezes, configurado em relatório extenso, excessivamente analítico e pouco atrativo para os interessados diretos (clientes e usuários em geral), que, como leigos, se vêm à margem da pesquisa e não, como de fato deveria ocorrer, seus beneficiários;

Pouca disseminação da literatura no âmbito da APO, destinada a leigos.

De acordo com Orsntein e Roméro (1992), existem três tipos de APO: indicativa, investigativa ou de médio prazo e diagnóstico ou de longo prazo. A primeira indica os aspectos positivos e negativos do objeto de estudo com visitas rápidas e entrevistas com usuários-chave, a segunda é a APO anterior com explicitações de critérios referenciais de desempenho, e a terceira define detalhadamente critérios de desempenho, tendo em mente a estrutura organizacional do objeto de estudo e exige recursos bem maiores que os utilizados nas APOs anteriores. 
A APO é entendida como parte do processo projetual, pois muitas vezes quando se prioriza a estética, a imagem, o simbolismo, a forma, a monumentalidade, esquece-se da verdadeira função da arquitetura, que se relaciona com o ser humano, do conforto ambiental, dos fatores psico-comportamentais, culturais, sociais, reduzindo a importância do usuário e o seu bem-estar.

Em relação à equipe técnica, essa deve ser, sempre que possível, interdisciplinar. O coordenador geral da pesquisa deve ser um especialista na área, com ampla visão do assunto, apresentando capacidade comprovada para gerenciar equipes. Ao pesquisador devem estar subordinados estagiários graduandos em arquitetura e urbanismo ou de áreas afins, divididas em duas categorias: permanentes e temporários. Os permanentes devem possuir grande interesse na área de pesquisa e são responsáveis pelo supervisionamento e também pela tabulação dos resultados. Os temporários são contratados exclusivamente para aplicação dos questionários da pesquisa.

Os consultores dão caráter interdisciplinar à pesquisa, sendo eles oriundos de várias áreas, tais como psicologia, custos, estatística, patologia e manutenção de edifícios, em conforto ambiental.

Os prazos para desenvolvimento e finalização do trabalho estão relacionados com o tipo de cliente, estrutura, equipe técnica e também nível de envolvimento do usuário, dimensões e escala da pesquisa. Deve-se tentar executar a pesquisa no menor prazo e com o menor custo possível. Mas na verdade, quanto maior o nível de precisão, maiores são os custos. O custo de uma pesquisa depende da relação entre o orçamento disponível e o projeto de pesquisa previsto. Segundo Preiser, Binowitz e White (1988, p. 32)

Tipos de influência no custo do trabalho em APO incluem número, dimensão, localização dos edifícios a serem avaliados, número e a complexidade dos aspectos de desempenho do edifício a serem medidos tecnicamente, o rigor com o qual o estudo será implementado, os tipos e quantidades de instrumentos de avaliação a serem utilizados, o número de participantes da equipe técnica, o cronograma da APO e o tipo do produto a ser adotado.

Viagens, números de consultores, tempo de computação, materiais, cópias, e outros custos também podem afetar a atividade. Normalmente, os custos são muito baixos considerando-se os benefícios proporcionados pelos resultados. O produto pode ser um relatório, um vídeo, uma mesa redonda ou recomendações para elaboração de manuais e complementação de normas técnicas. O formato do produto e objetivo do cliente também variam de acordo com os custos. Os métodos devem ser relatados na entrega e os resultados e recomendações devem ser colocados à disposição.

As variáveis abrangidas por uma APO são construtivas, funcional, econômica, estética/simbólica, comportamental/psicológica, além da estrutura organizacional. 
Em relação às avaliações técnico construtivas e de conforto ambiental, o avaliador é designado a fazer distinções das observações, entrevistas, aplicação de questionários e julgamento de valores em relação a: solo e fundação, estrutura linear, estrutura especiais, estruturas mistas, cobertura, drenagem de águas pluviais, impermeabilização, segurança contra incêndio, alvenarias, divisórias leves, revestimentos, forros, pinturas, acabamentos, caixilharia, vidraçaria, instalações elétricas e eletromecânicas, instalações hidrossanitárias, telefonia, e paisagismo. As observações, a respeito do conforto ambiental, são: conforto térmico, ventilação natural, condicionamento de ar e ventilação artificial, iluminação natural, iluminação artificial, conforto acústico e conservação de energia.

A avaliação técnico-funcional considera a avaliação do projeto arquitetônico proposto e o construído tratando de: planejamento/programa do projeto, áreas mínimas, dimensionamentos mínimos, armazenamento, circulação interna, fluxos de trabalho, áreas de lazer e descanso, flexibilização dos espaços, potencial para mudanças e ampliações, adequação do mobiliário fixo, móveis e equipamentos especiais, sinalização/orientação interna e externa, circulação externa para pedestres e veículos, adequação externa e interna a deficientes físicos e visuais, segurança contra acidentes pessoais, segurança contra roubo, facilidade de manuseio de órgãos do edifício, mobiliário e equipamentos, relação entre área útil e área de circulação, relação entre área efetivamente ocupada e em uso e área eventualmente sem uso.

A avaliação técnico-econômica refere-se a índices econômicos extraídos da produção e uso do ambiente construído que podem determinar parâmetros para medir a eficiência do ambiente construído (MASCARÓ, 1985), sendo eles: relação custo versus benefício, variação por metro quadrado de área construída, variação do custo de construção do edifício em função da largura ou comprimento da planta-tipo, variação do custo da construção em função do tipo da sua estrutura, variação do custo da construção em função da sua altura, variação da construção em função da quantidade de fachadas, variação do custo de construção em função da instalação de elevadores, variação do custo de construção em função do tipo de circulação horizontal e vertical, variação do custo do edifício em função da sua compacidade, variação dos custos de manutenção do edifício em uso, variação dos custos das intervenções físicas necessárias para otimizar o desempenho do edifício, no decorrer de seu uso.

A avaliação técnico-estética pretende avaliar formas, volumes, a beleza, o estilo e a percepção ambiental do ponto de vista do avaliador e do usuário. Essa é considerada a mais difícil de ser analisada, principalmente, em países em desenvolvimento como o nosso em que a questão estética é massacrada em função das questões técnico-construtivas, funcionais e econômicas. Uma série de sub-variáveis podem ser avaliadas sobre essa ótica 
como por exemplo: cor e pigmentação, textura, volumetria, massas, ritmo, complexidade de formas e padrões, idade aparente, linha de telhado/cobertura, efeitos lumínicos, dimensão estética, entre outros.

A avaliação comportamental é a variação básica da APO, pois lida com várias categorias e/ou usuários. É analisada a partir de procedimentos estatísticos compatíveis e pode-se ter as seguintes sub-variáveis, dentre outras: adequação ao uso e à escala humana, proximidade, privacidade, território, interação, imagem e codificação ambiental, identidade cultural, comunicação, ordem social, hierarquia dominante, densidade populacional, controle da dispersão ou atração de pessoas, entre outros.

Com os estudos da APO, algumas diretrizes e soluções podem ser realizadas e não precisam ser obrigatoriamente físicas. Por exemplo, algumas reuniões entre diretores e funcionários é uma das soluções que pode otimizar a comunicação e trazer mais rapidez para o processo do trabalho. Uma APO deve ser cuidadosamente calculada e formulada pois o planejamento adequado da pesquisa implica em um correto levantamento de dados e visa o alcance das metas dentro dos prazos previstos.

A coleta de dados para a APO é constituída de oito subetapas: levantamento da memória do projeto e da construção, cadastro atualizado dos ambientes construídos (as built), cadastro atualizado do mobiliário e dos equipamentos, levantamento, tabulação de dados e informações coletadas junto aos usuários, levantamento técnico-construtivo, conforto ambiental e funcional, levantamento de normas, códigos e especificações técnicas existentes, estabelecimento de critérios e padrões.

Quando se fala em estabelecimento de critérios e padrões deve-se lidar com a possibilidade da inexistência de normas e especificações técnicas para a tipologia de edifícios estudada pela APO durante a análise. No Brasil, país que possui pouca normatização, lidamos com esse fato constantemente.

Em relação às edificações estudadas, nesse trabalho, não é diferente. Os Hemocentros seguem normas definidas pela Vigilância Sanitária que abrangem todo o país e todas as especialidades médicas. As normas sugeridas pela Resolução da Diretoria Colegiada (RDC) do Sistema Nacional de Vigilância Sanitária limitam-se apenas às instalações, quantidades e metragem dos ambientes; não citam a diferenciação de normas quanto aos aspectos bioclimáticos e, menos ainda, atitudes que visem a diminuição de custos de manutenção da edificação, como pode-se observar no Quadro 1. 
Quadro 1: Níveis de complexidade de serviços de hemoterapia e legislação - exigências arquitetônicas/ instalações

\begin{tabular}{|c|c|c|c|c|}
\hline \multicolumn{5}{|c|}{ UNIDADE FUNCIONAL: 4 - APOIO AO DIAGNÓSTICO E TERAPIA (cont.) } \\
\hline \multirow[t]{2}{*}{ No ATIV. } & \multirow[t]{2}{*}{ UNIDADE / AMBIENTE } & \multicolumn{2}{|l|}{ DIMENSIONAMENTO } & \multirow[t]{2}{*}{ INSTALAÇŌES } \\
\hline & & $\begin{array}{l}\text { QUANTIFICAÇÃO } \\
\text { (min.) }\end{array}$ & DIMENSÃO (min.) & \\
\hline 4.9 & Hemoterapia e Hematologia & & & \\
\hline 4.9 .1 a 4.9 .14 & $\begin{array}{l}\text { Coleta, Processamento, Análise } \\
\text { lab. e Estocagem/Distribuiçăo }\end{array}$ & & & \\
\hline 4.9 .1 & $\begin{array}{l}\text { Sala para recepção, registro e } \\
\text { espera de doadores }{ }^{1}\end{array}$ & 1 (de cada) & 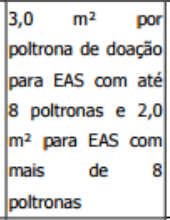 & \\
\hline 4.9 .2 & Arquivo de doadores ${ }^{1}$ & & $\begin{array}{|lr|}\text { A } & \text { depender } \\
\text { tecnologia utilizada }\end{array}$ & \\
\hline 4.9 .3 & $\begin{array}{l}\text { Sala/área para triagem } \\
{\text { hematológica }{ }^{1}}\end{array}$ & & $4,0 \mathrm{~m}^{2}$ & $\mathrm{HF} ; \mathrm{EE}$ \\
\hline $4.9 \cdot 3 ; 4.9 \cdot 6 ; 4.9 .18$ & Triagem clínica ${ }^{1}$ & & $7,5 \mathrm{~m}^{2}$ & \\
\hline $4.9 .4 ; 4.9 .6 ; 4.9 .18$ & $\begin{array}{l}\text { Sala para coleta de sangue de } \\
\text { doadores }{ }^{1} \\
\text { - Área de aféreses de doador }\end{array}$ & 1 (de cada) & 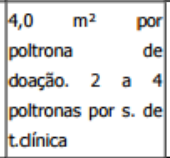 & \\
\hline $4.9 .6 ; 4.9 .18$ & $\begin{array}{l}\text { Sala para recuperaçăo de } \\
\text { doadores }{ }^{1}\end{array}$ & & $6,0 \mathrm{~m}^{2}$ & $\mathrm{HF} ; \mathrm{FO}$ \\
\hline 4.9 .7 & $\begin{array}{l}\text { Sala para processamento de } \\
\text { sangue }^{2}\end{array}$ & & 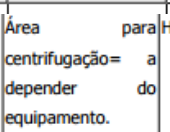 & $\mathrm{HF} ; \mathrm{EE} ; \mathrm{ED} ; \mathrm{E} ; \mathrm{AC}$ \\
\hline 4.9 .11 & Área/sala para pré-estoque $2 / 6$ & 1 & \begin{tabular}{|l|}
$2,0 \mathrm{~m}^{2}$ (por freezer \\
ou refrigerador)
\end{tabular} & EE \\
\hline 4.9 .10 & $\begin{array}{l}\text { Sala para liberação e rotulagem } \\
2\end{array}$ & & $6,0 \mathrm{~m}^{2}$ & \\
\hline 4.9 .7 & $\begin{array}{l}\text { Sala para procedimentos } \\
\text { especiais (abertura do sistema, } \\
\begin{array}{ll}\text { alicotagem, lavagem de } \\
\text { hemácias, etc) }\end{array}\end{array}$ & & ADE & ADE \\
\hline $4.9 .13 ; 4.9 .14$ & 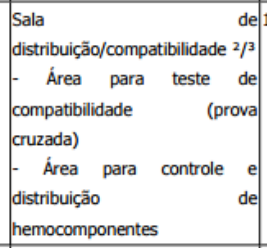 & & $12,0 \mathrm{~m}^{2}$ & $\mathrm{HF} ; \mathrm{ED} ; \mathrm{EE}$ \\
\hline 4.9 .11 & $\begin{array}{l}\text { Área/sala para estocagem de } \\
\text { hemocomponentes }{ }^{3}\end{array}$ & & \begin{tabular}{|lll}
2,0 & $\mathrm{~m}^{2} \mathrm{p} /$ freezer \\
ou & refrigerador. \\
depender & do \\
equipamento & no \\
caso do uso & de \\
câmaras frias &
\end{tabular} & EE; ADE \\
\hline 4.9 .12 & \begin{tabular}{|l|} 
Laboratório de controle de \\
qualidade do produto final
\end{tabular} & & $10,0 \mathrm{~m}^{2}$ & $\mathrm{HF} ; \mathrm{ED} ; \mathrm{ADE}$ \\
\hline 4.9 .15 a 4.9 .18 & \begin{tabular}{|l|} 
Atendimento a Pacientes \\
Hematológicos
\end{tabular} & & & \\
\hline 4.9 .15 & Sala de coleta de material 4 & 1 & $3,5 \mathrm{~m}^{2}$ & HF \\
\hline $1.7 ; 4.9 .6$ & Consultório indiferenciado 4 & 1 & $7,5 \mathrm{~m}^{2}$ & HF \\
\hline $4.9 .16 ; 4.9 .17 ; 4.9 .18$ & \begin{tabular}{|l|} 
Sala de transfusăo 4 \\
- Box de transfusão individual \\
(isolamento) \\
- Área de transfusăo coletiva \\
- Área de aféreses terapêutica
\end{tabular} & 1 & 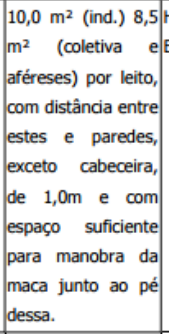 & $\begin{array}{l}\text { HF;FO;FAM; } \\
\text { EE;ED } \\
\\
\end{array}$ \\
\hline 4.9 .18 & $\begin{array}{l}\begin{array}{l}\text { Posto de enfermagem e } \\
\text { serviços } 4\end{array} \\
\text { t }\end{array}$ & $\begin{array}{l}1 \text { a cada } 12 \text { leitos de } \\
\text { transf. ou fração }\end{array}$ & $6,0 \mathrm{~m}^{2}$ & $\mathrm{HF} ; \mathrm{EE}$ \\
\hline
\end{tabular}

Fonte: Resolução RDC 151 de 21/08/01, publicada no Diário Oficial de 22/08/01 
Nesses casos, onde há a inexistência de normas, o conjunto de critérios adotados é formulado a partir da experiência profissional dos membros da equipe técnica. Sendo assim, esses critérios podem ser mais ou menos restritivos para uma certa edificação, sem gerar critérios padronizados para todas as edificações similares.

O diagnóstico é a etapa mais importante da APO, devendo ser cuidadosamente dimensionado, pois a partir dele são extraídas as recomendações a curto, médio e longo prazo. As recomendações podem ser construtivas, funcionais, comportamentais, que orientem a implementação de um plano diretor e flexibilização dos espaços visando melhor desempenho e qualidade ambiental da edificação em análise.

A reprodutividade da APO, para diversos estudos de caso semelhantes, propicia a geração de diretrizes e critérios para futuros projetos, operação e manutenção de ambientes além do estabelecimento de normas.

A intenção é documentar bons exemplos e maus exemplos de arquitetura, buscando não gerar cópias de projetos, mas sim recomendações projetuais que abarquem além das atividades a serem desenvolvidas, o clima local. Seriam recomendações técnicas e bioclimáticas para projetos da Hemorrede Brasil.

\subsection{RETROFIT}

O nome Retrofit vem do latim "retro", que significa movimentar-se para trás e "fit" do inglês, que significa adaptação, ajuste. O termo surgiu no final da década de 1990 nos Estados Unidos e Europa, inicialmente na indústria aeronáutica, em referência à atualização das aeronaves. Com o passar do tempo, passou a ser empregado também na Construção Civil, tendo em vista atualizar edificações melhorando seu desempenho e vida útil.

O processo de modernização e atualização de edificações visa torná-las contemporâneas, valorizando edifícios antigos, prolongando sua vida útil, seu conforto e sua funcionalidade com a incorporação de avanços tecnológicos e da utilização de materiais de última geração (ROCHA e QUALARIN, 2001)

Nas últimas décadas, devido à crise energética e à disseminação de métodos sustentáveis voltados à construção civil, as edificações antigas tornaram-se alvo de políticas nacionais e internacionais para redução do consumo e produção de energia.

Estratégias de eficiência energética passaram a ser gradativamente integradas tanto nos projetos existentes como na elaboração de novos projetos. Segundo Silva (2013, p. 24), "[...] os critérios de sustentabilidade passaram a integrar a formulação dos programas de atividades contemporâneos e, consequentemente, no próprio desenvolvimento das atividades regulares da construção civil". 
O Retrofit arquitetônico consiste justamente na reformulação e adequação de um edifício existente às novas funções e às necessidades de seus usuários, utilizando estratégias para minimizar o consumo energético e melhorar o conforto ambiental. Ressaltase que, ao constituir-se em uma ação de adequação e manutenção da edificação, em contraposição à demolição e à construção de uma nova edificação, o Retrofit contribui também para a redução do consumo de novos recursos naturais. Retrofit, de acordo a Instrução Normativa № 2 (BRASIL, 2014) no âmbito do uso da Etiqueta Nacional de Conservação de Energia (ENCE), "[...] é qualquer reforma que altere os sistemas de iluminação, condicionamento de ar ou a envoltória da edificação".

As primeiras práticas de Retrofit, devido à forte legislação já existente nos Estados Unidos e Europa, não permitiram a substituição do patrimônio arquitetônico. Há a preocupação em preservá-lo, permitindo a utilização adequada do imóvel, como pode ser observado abaixo, numa edificação que foi submetida ao Retrofit (figura 15)

Figura 11: Exemplo de Retrofit. Foto antes e depois -Praça XV em Porto Alegre

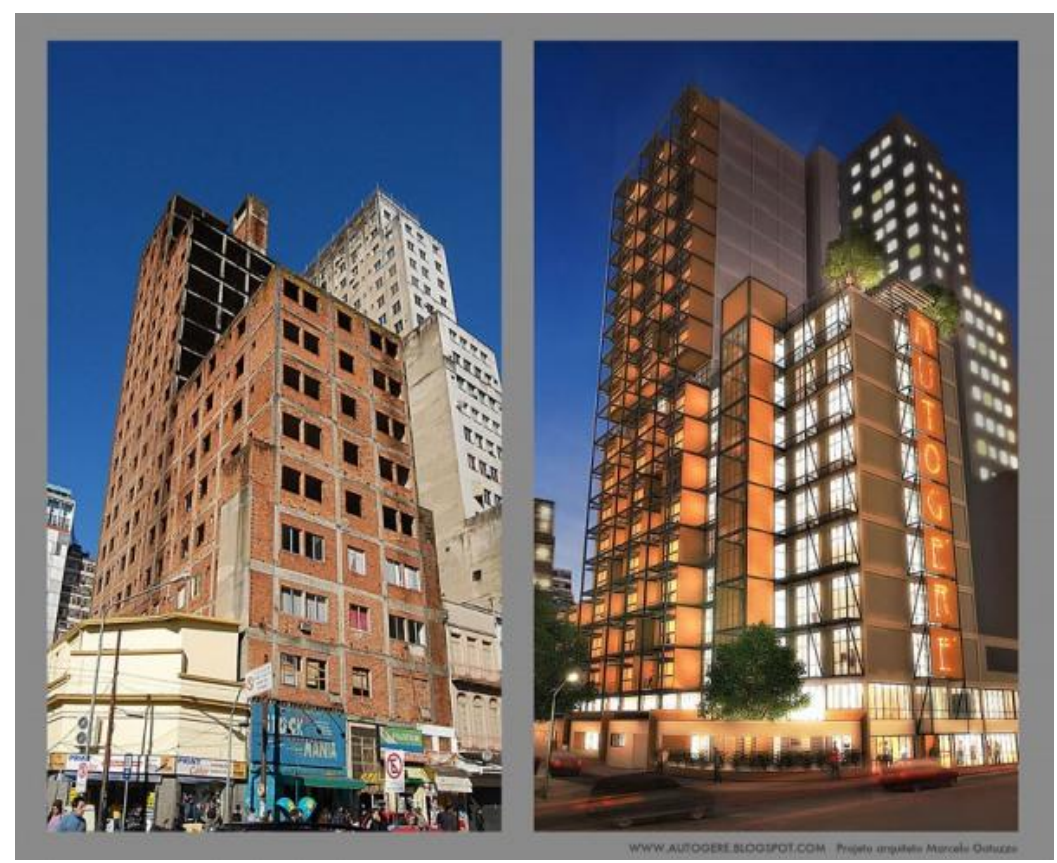

Fonte: marketing.imob.com . Acesso 08 ago 2016.

Já bastante rotineira na Europa, as práticas de Retrofit, chegam a 50\% das obras. Na Itália e na França este índice é cerca de 60\%. Tais práticas de reabilitação em edificações comerciais, residenciais, públicas e industriais objetivam valorizar as velhas edificações, aumentando sua vida útil por meio da incorporação de avanços tecnológicos e da utilização de materiais de última geração, desenvolvendo assim uma prática mais econômica e eficiente que a de demolição.

Para melhor compreensão Vale (2006), conceituou algumas definições relacionadas ao Retrofit, a saber: 
Diagnóstico: Descrição do problema patológico incluindo sintomas, causas, mecanismo e caracterização da gravidade do problema;

Conservação: De caráter sistêmico, corresponde a um conjunto de ações destinadas ao prolongamento do desempenho da edificação, auxiliando assim, o processo de controle da construção;

Manutenção: Conjunto de ações com o objetivo de reduzir a velocidade de deterioração dos materiais e de partes das edificações. Esta pode ser subdividida em: manutenção preventiva (ideal) e na manutenção corretiva;

Profilaxia: Forma de organização, através da listagem de todos os materiais e procedimentos necessários, visando à correção de anomalias existente;

Reforma: Intervenção que consiste na restituição do imóvel à sua condição original;

Reparos: Intervenções pontuais em patologias localizadas;

Reconstrução: Renovação total ou parcial das edificações desativadas ou destinadas à reabilitação.

Recuperação: Compreende a correção das patologias de modo a reconduzir a edificação a seu estado de equilíbrio;

Reabilitação: Ações com o objetivo de recuperar e beneficiar edificações, por meio de mecanismos de atualização tecnológica;

Restauração: Corresponde a um conjunto de ações desenvolvidas de modo a recuperar a imagem, a concepção original ou o momento áureo da história da edificação em questão. A expressão tem sua utilização no que se refere a intervenções em obras de arte.

Terapia: Procedimento que visa às especificações para recuperação e eliminação dos problemas patológicos das edificações.

Para Rocha e Qualharini (2001), o Retrofit trata de qualquer reforma, que coloca o velho em forma de novo, preservando seus valores estéticos e históricos originais, adotando o conceito de sustentabilidade, além de buscar preservar os elementos que caracterizam a edificação ao invés de descartá-los.

O Retrofit também se aplica às edificações relativamente novas quando 0 empreendedor deseja substituir os sistemas prediais inadequados ou em situações em que a edificação se encontra inacabada ou abandonada.

Uma série de itens pode justificar um Retrofit, tais como: aproveitar a estrutura existente no entorno, impacto na paisagem urbana, preservação do patrimônio histórico e cultural, déficit habitacional e sustentabilidade ambiental. Também quando as alterações se mostram mais econômicas e eficientes que a demolição seguida de uma reconstrução.

A principal ação do Retrofit é analisar, customizar, adaptar, agregar ao edifício características que proporcionem melhor desempenho energético, melhoria funcional, acessibilidade, e que valorize a estética, melhor desempenho e prolongamento da vida útil.

A metodologia do Retrofit envolve sete etapas (Quadro 2), conforme apontam Moraes e Quelhas (2012, p. 450):

Quadro 2: Etapas do Retrofit segundo Nunes (2012)

Análise mercadológica e financeira, incluindo valores, estudo vocacional e viabilidade comercial;

Definição do conceito do projeto, o que envolve análise das possibilidades de expansão de área;

Legislação - plano jurídico;

Critérios de reaproveitamento de materiais e sistemas;

Diagnóstico - etapa que considera elementos como a história da edificação; estudo de arquitetura e eficiência da laje; análise das condições de sistemas e equipamentos;

Propostas de implementação, incluindo vários cenários, entre eles, da arquitetura, elétrica, dados, voz, elevador e fachada.

Comercialização.

Fonte: MORAES e QUELHAS (2012, p. 450). Adaptado pela autora, 2016. 
O processo do Retrofit busca o reaproveitamento, a economia e a renovação por meio de uma solução integral, desde as soluções de fluxos até as de conforto ambiental. Os profissionais envolvidos também devem se preocupar com a integração que essas futuras instalações e modificações afetarão as gerações futuras e as possibilidades de substituição das tecnologias ao longo do tempo. Deve-se projetar pensando nas futuras mudanças de layout, nas possibilidades de automação, deve-se pensar nas cargas que poderão ser colocadas em cada ambiente, visando a dinâmica e a adaptabilidade do ambiente construído, tendo em vista o melhor aproveitamento e prolongamento da vida útil.

Para tanto, antes das ações de Retrofit, alguns conceitos sustentáveis devem ser observados quanto aos materiais empregados (ARAUJO, 2004, apud MORAES e QUELHAS, 2012, p. 451) como segue:

Quadro 3: Critérios para seleção de materiais aplicados em ações de Retrofit

Ser renovável ou não esgotar os recursos naturais;

Não agredir o meio ambiente e contribuir para a sua melhoria, retirando dele resíduos que comprometem o uso do solo, lençol freático, atmosfera, vida útil de aterros sanitários e condições de saúde das comunidades;

Ser benéfico à saúde dos seres vivos e do ecossistema;

Não contaminar o ar, água, terra no processo produtivo e pós-uso;

Não gerar resíduos na produção ou uso;

Ser de matéria-prima natural, reciclada ou reciclável;

Ser fabricado industrialmente, devendo atender a demandas crescentes;

Conter insumos que contribuam para um elevado desempenho ambiental do produto;

Não consumir grandes quantidades de energia para a sua extração, produção e/ou funcionamento ou utilizar fontes de energia renovável;

Conter especificações técnicas constando diferencial ambiental e desempenho ambiental;

Conter menor quantidade possível de embalagens, de preferência recicladas e biodegradáveis. Em último caso, recicláveis;

Ter custo competitivo, sendo uma alternativa aos similares convencionais de mercado;

Atingir a população dos grandes centros urbanos, sem necessidade de ser usado apenas em áreas rurais ou com área verde disponível;

Contribuir para a consolidação do eco negócio e do mercado verde;

Contribuir para o desenvolvimento de um modelo socioeconômico sustentável;

Contribuir para a educação ambiental dos usuários e vizinhos;

Sempre que possível, os eco materiais devem permitir flexibilidade e adaptabilidade arquitetônica do edifício para futuras reformas, ampliações e alterações de layout, facilitando mudanças com o mínimo custo de materiais e energia.

Fonte: MORAES e QUELHAS (2012), adaptado pela autora, 2016.

Alguns cuidados são sugeridos antes da intervenção, tais como realizar um levantamento minucioso dos sistemas e equipamentos instalados e em uso; propor possíveis soluções, tentar aproveitar os equipamentos e sistemas interligando-os ao novo sistema a ser implantado, se possível; documentar em um memorial descritivo todas as modificações ocorridas, buscando informar ao responsável de um futuro Retrofit os caminhos percorridos, as dificuldades, facilidades e surpresas da edificação, facilitando futuros trabalhos.

A intenção do Retrofit em um edifício é readequá-lo e devolvê-lo aos usuários de maneira mais eficiente, mais confortável, para qualquer usuário em qualquer fase da vida, seja um ambiente público, ou privado. Trata-se de uma ferramenta limpa e confiável que evita a obsolescência das edificações, possibilitando uma recuperação segura dentro dos 
aspectos históricos, econômicos e ecológicos, proporcionando mais uso, adequado às necessidades dos usuários, além de evitar as demolições que geram muitos resíduos e impactos ambientais.

\subsection{ETIQUETAGEM DE EDIFICAÇÕES}

Apesar do brasileiro não estar entre um dos maiores consumidores de energia do mundo, o consumo de energia no Brasil tem crescido significativamente nos últimos anos. O Balanço Energético Nacional (BEN) de 2005 indicou um aumento da participação da energia elétrica no consumo final, de 15,7\% em 2002 para 16,2\% em 2004.

O crescente consumo é uma realidade nos países desenvolvidos e em desenvolvimento, sendo essa uma das grandes questões a serem enfrentadas pelas economias desses países.

Países considerados desenvolvidos como Austrália, Inglaterra, Japão, Alemanha, e Estados Unidos apresentam consumo de energia elétrica de 5.000 a 13.000 KWh por habitante. O Japão e a Alemanha apresentam um consumo estável nos últimos anos, diferentemente dos Estados Unidos que entre 1991 e 2000 apresentou taxa de crescimento de $14 \%$, enquanto na Austrália o consumo por habitante aumentou $18 \%$ e na Inglaterra aproximadamente 16\% (Gráfico 8). Enquanto isso países em desenvolvimento como Brasil, China e Tailândia apresentam um consumo de $2000 \mathrm{KWh} / \mathrm{hab}$. O Brasil apresenta um nível de crescimento significativo nos últimos nove anos de $24 \%$, mas seu consumo per capita é abaixo do consumo de países como a África do Sul (LAMBERTS e CARLO, 2004)

Gráfico 8: Evolução do Consumo de Energia Elétrica em alguns países entre 1960-2008.

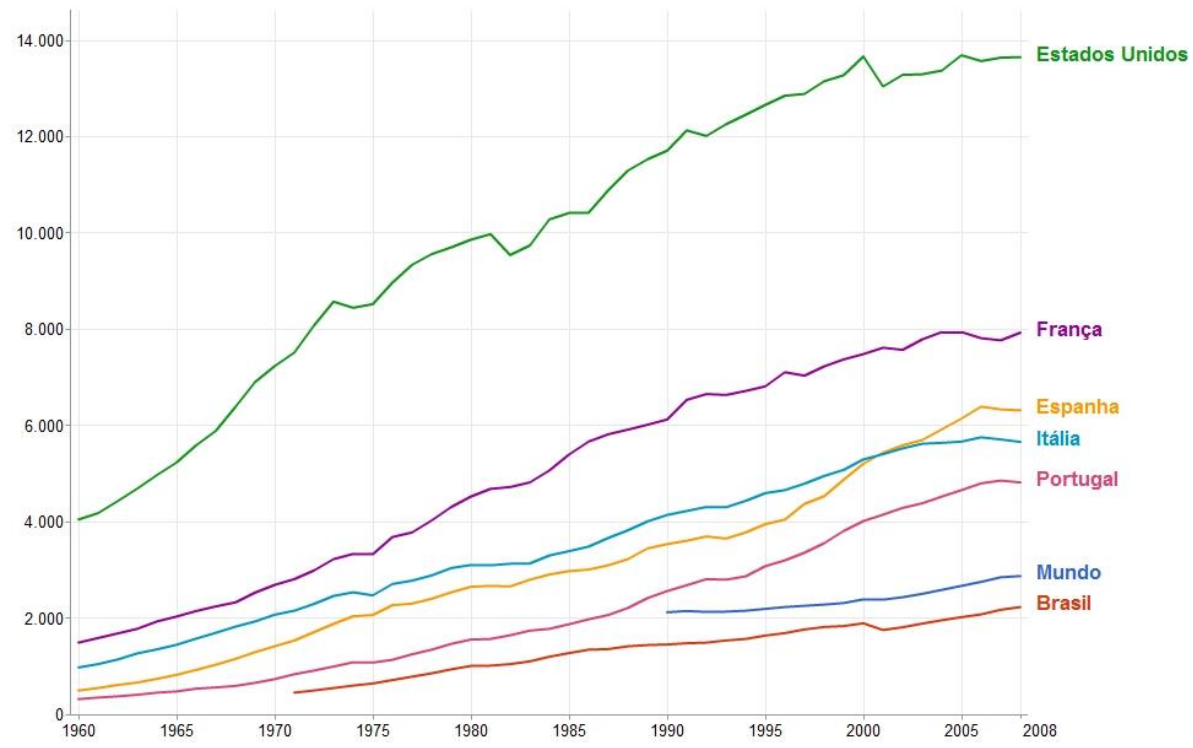

Fonte: blogs.odiario.com. Acesso 03 set. 2016.

O aumento do consumo de energia elétrica está diretamente ao crescimento do PIB, indicando a relação entre energia elétrica e a economia nacional (Gráfico 9). 
Gráfico 9: Relação entre consumo de energia elétrica e PIB.

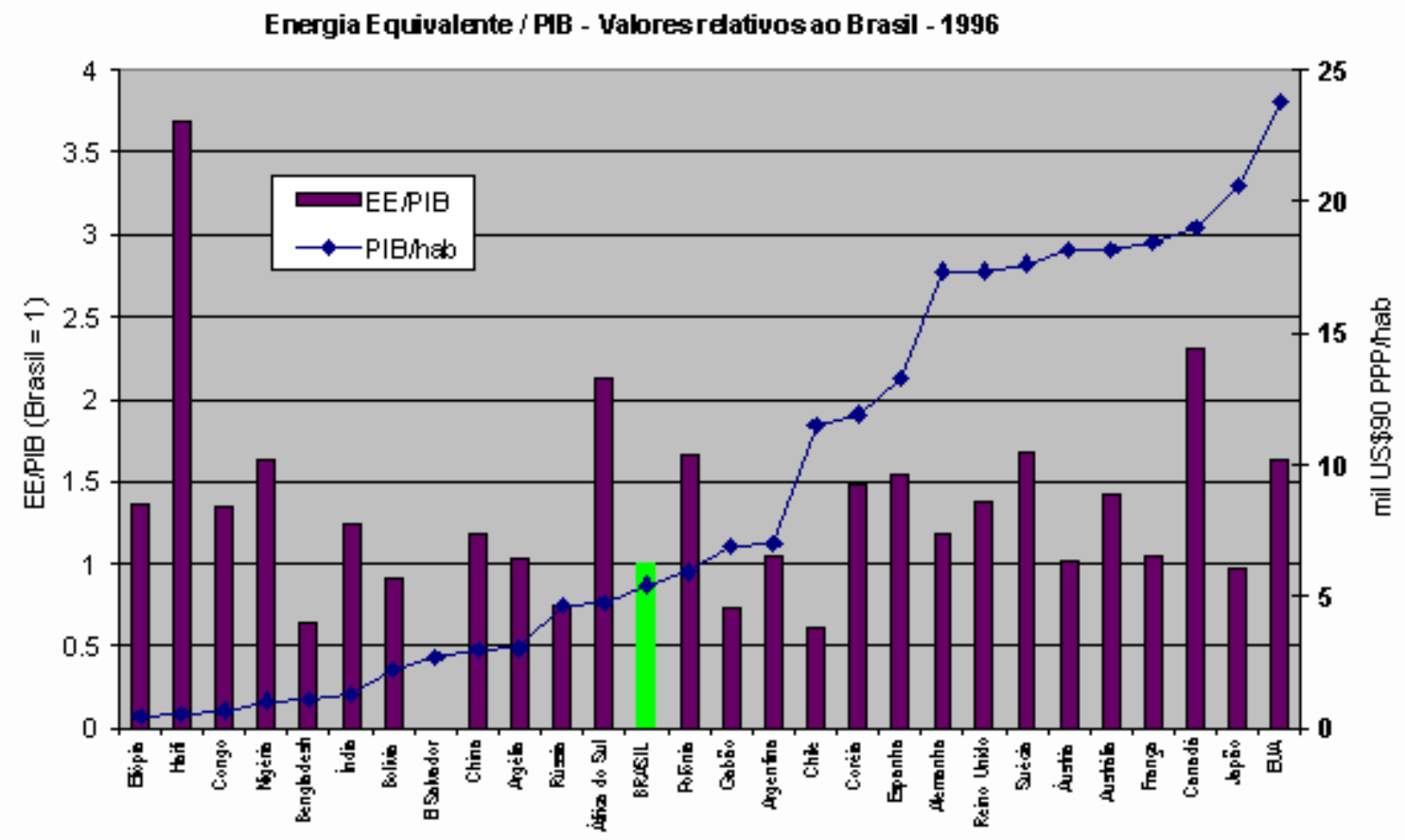

Fonte: http://ecen.com/matriz/eee23/dm1ee_el.htm. Acesso 03 set. 2016.

No gráfico 10, tem-se a evolução do consumo de energia elétrica no setor residencial, comercial e público no Brasil de 1987 a 2004. Podemos perceber um aumento significativo do setor residencial em relação aos demais setores. E pode-se perceber uma leve queda em 2001 devido ao período de racionamento de energia. Os valores atuais ainda são inferiores em 2004 após o período de racionamento.

Gráfico 10: Consumo de energia por setores entre 1990 e 2011.

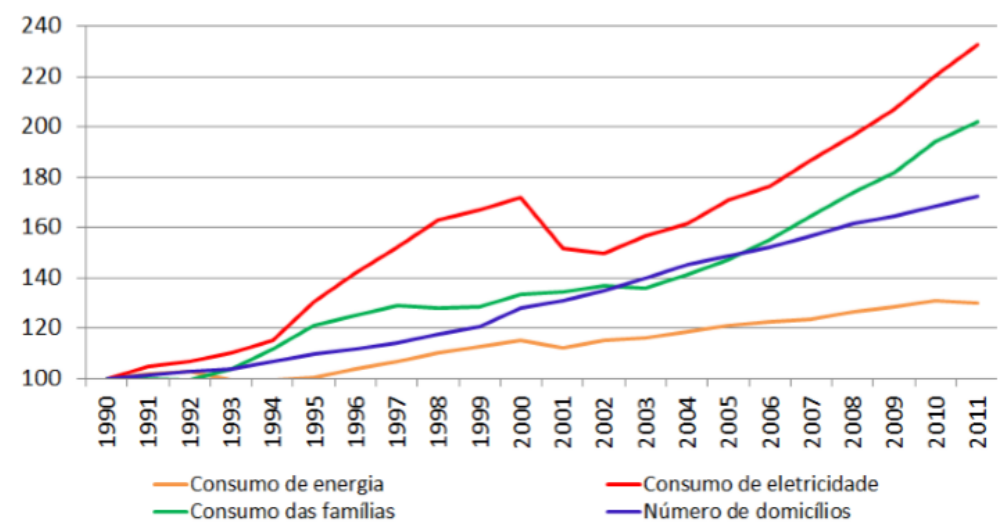

Fonte: http://ecen.com/matriz/eee23/dm1ee_el.htm. Acesso 03 set. 2016/.

No período de 1997 a 2000, houve um crescimento no consumo de energia elétrica, após a estabilização da economia, quando o PIB cresceu 3,9\% ao ano. De 1994 a 1995, a taxa de crescimento do consumo de energia elétrica no setor residencial atingiu 
aproximadamente 14\%. Em 2004, o crescimento econômico proporcionou um PIB de 4,9\%, ressaltando um forte crescimento no consumo de eletroeletrônicos decorrente do crescimento da população empregada e da recuperação dos rendimentos médios. Neste ano, a venda industrial de eletrodomésticos da linha branca cresceu 30,9\% comparado com o ano de 2003.

Os dados de 2005, demonstram que o uso final de ar condicionado representa $16 \%$ do consumo total de eletricidade, o dobro do valor da pesquisa de 1998 , o que indica a necessidade dos usuários em soluções artificiais para melhor conforto térmico das edificações (Gráfico 11).

Gráfico 11: Uso final do consumo de eletricidade total no setor residencial em 2005.

BRASIL

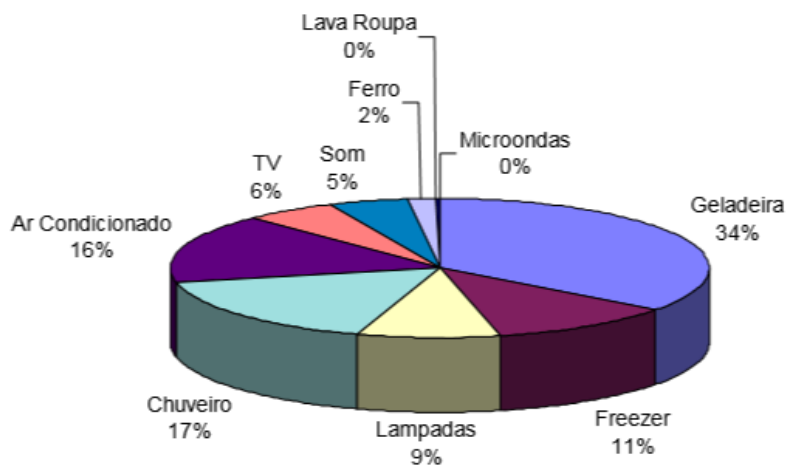

Fonte: PROCEL EDIFICA EDIFICA EDIFICA (2011).

A primeira tentativa de se promover a eficiência energética no país surgiu em 2001 após as consequências da crise energética. Nesse ano foi sancionada a Lei n 10.295 de 17 de outubro de 2001 (BRASIL, 2001). Em outubro de 2003, foi lançado o Plano de Ação para Eficiência Energética em Edificações - conhecido por PROCEL EDIFICA Edifica. Nele foram estabelecidas seis vertentes de ação, a saber: arquitetura bioclimática, indicadores referenciais para edificações, certificações de materiais e equipamentos, regulamentação e legislação, remoção de barreiras à conservação da energia e, por fim, educação. Cada uma dessas ações representa uma série de projetos que visa implementar a eficiência energética na cultura construtiva brasileira, desde a fase anterior ao projeto através da certificação de materiais e educação até a revisão de leis e normativas de eficiência energética.

Nas discussões dos estudos desenvolvidos no âmbito do projeto, verificou-se que as várias soluções eficientes de projeto em conjunto com o uso de equipamentos eficientes permitem diferentes níveis de classificação do edifício. Dessa maneira, é possível desenvolver trabalhos com escala de variação para definição de uma classificação que incentive a construção de edificações cuja eficiência esteja acima do mínimo requerido por normas específicas. A partir dessas considerações, foi desenvolvida uma regulamentação 
para etiquetagem de edificações ao invés de prescrições mínimas, possibilitando edificações diferenciadas daquelas tradicionais do mercado por serem mais eficientes $e$, consequentemente, dotadas de soluções técnico-construtivas com melhor desempenho.

Regulamentar a etiquetagem de nível de eficiência energética para edificações públicas e comerciais é de caráter voluntário a partir de 2007 , e de caráter obrigatório a partir da data da sua implementação em 2012.

Desde agosto de 2014, a Etiquetagem de Edificações tornou-se obrigatória em edifícios da Administração Pública Federal direta, autárquica e fundacional. A Instrução Normativa SLTI n. 2/2014, do Ministério de Planejamento Orçamento e Gestão (MPOG) dispõe sobre as regras para a aquisição ou locação de máquinas e aparelhos consumidores de energia e o uso da Etiqueta Nacional de Conservação de Energia (ENCE) nos projetos e respectivas edificações públicas federais novas ou que recebam Retrofit. Segundo a legislação para as edificações, os projetos devem ser desenvolvidos ou contratados visando, obrigatoriamente, à obtenção da ENCE Geral de Projeto classe "A", assim como a construção da nova Edificação deve ser executada ou contratada de forma a garantir a obtenção da ENCE Geral da Edificação Construída classe "A".

A intenção é criar regulamentação mínima para edifícios comerciais e públicos, com área mínima de $500 \mathrm{~m}^{2}$ ou com tensão de abastecimento superior a 2,3kV, incluindo edificações que fazem uso de ar condicionado, parcialmente condicionados e naturalmente ventilados.

A regulamentação é dividida em três requisitos: eficiência e potência instalada do sistema de iluminação; eficiência do sistema de ar condicionado e desempenho térmico da envoltória do edifício.

As edificações podem ser classificadas por diferentes níveis de eficiência energética que variam de $A$ (mais eficiente) e $E$ (menos eficiente) (Tabela 10). Para isso, pesos são atribuídos e, de acordo com a pontuação final, é obtida uma classificação geral. Os pesos estão distribuídos da seguinte forma: sistema de iluminação $(\mathrm{DPI})=30 \%$, sistema de ar condicionado $(C A)=40 \%$ e Envoltória $(E n v)=30 \%$. A classificação geral do edifício é calculada de acordo com a distribuição dos pesos através da seguinte equação:

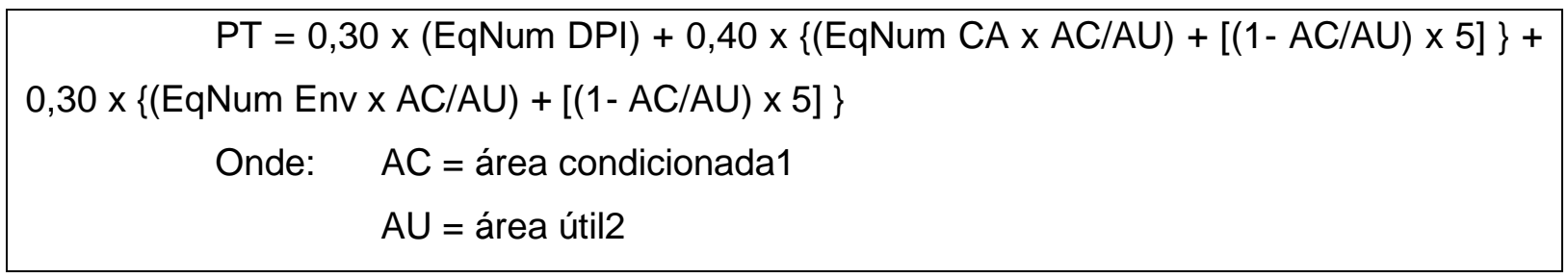

Os equivalentes numéricos (EqNum) para os níveis de eficiência de cada requisito são obtidos conforme Tabela 10 .. 
Tabela 10: Equivalente numérico para cada nível de eficiência (EqNum)

\begin{tabular}{|c|c|}
\hline A & $\mathbf{5}$ \\
\hline B & $\mathbf{4}$ \\
\hline C & $\mathbf{3}$ \\
\hline D & $\mathbf{2}$ \\
\hline E & $\mathbf{1}$ \\
\hline
\end{tabular}

Fonte: PROCEL EDIFICA (2011).

O número de pontos obtidos na equação acima irá definir a classificação geral da edificação (Tabela 11).

Tabela 11: Classificação final da edificação conforme pontos obtidos na equação.

\begin{tabular}{|c|c|}
\hline PT & Classificação Final \\
\hline 4,5 a 5 & A \\
\hline 3,5 a 4,4 & B \\
\hline 2,5 a 3,4 & C \\
\hline 1,5 a 2,4 & D \\
\hline 1 a 1,4 & E \\
\hline
\end{tabular}

Fonte: PROCEL EDIFICA (2011).

Como requisito geral para ser elegível, o edifício deve possuir circuito elétrico com possibilidade de medição centralizada por uso final: iluminação, ar condicionado e outros. Também devem-se cumprir alguns requisitos para serem classificados como A, como por exemplo, utilizar aquecimento solar de água, quando houver demanda para uso do sistema de água quente.

Para determinação do nível de iluminação de cada ambiente deve-se obedecer à NBR 5413 - Iluminância de Interiores (ABNT, 1992), conforme as recomendações da Tabela 12. 
Tabela 12: Limite máximo aceitável de densidade de potência de iluminação para o nível de eficiência pretendido.

\begin{tabular}{|c|c|c|c|c|}
\hline $\begin{array}{c}\text { Índice de } \\
\text { ambiente } \\
\mathrm{K}\end{array}$ & $\begin{array}{c}\text { Densidade de } \\
\text { Potência de } \\
\text { iluminação } \\
\mathrm{W} / \mathrm{m}^{2} / 100 l u x \\
(\text { Nível A) }\end{array}$ & $\begin{array}{c}\text { Densidade de } \\
\text { Potência de } \\
\text { iluminação } \\
\mathrm{W} / \mathrm{m}^{2} / 100 l u x \\
\text { (Nível B) }\end{array}$ & $\begin{array}{c}\text { Densidade de } \\
\text { Potência de } \\
\text { iluminação } \\
\mathrm{W} / \mathrm{m}^{2} / 100 l u x \\
\text { (Nível C) }\end{array}$ & $\begin{array}{c}\text { Densidade de } \\
\text { Potência de } \\
\text { iluminação } \\
\mathrm{W} / \mathrm{m}^{2} / 100 l u x \\
\text { (Nível D) }\end{array}$ \\
\hline 0,60 & 2,84 & 4,77 & 5,37 & 6,92 \\
\hline 0,80 & 2,43 & 3,86 & 4,32 & 5,57 \\
\hline 1,00 & 2,34 & 3,38 & 3,77 & 4,86 \\
\hline 1,25 & 2,12 & 3,00 & 3,34 & 4,31 \\
\hline 1,50 & 1,91 & 2,79 & 3,11 & 4,01 \\
\hline 2,00 & 1,88 & 2,53 & 2,77 & 3,57 \\
\hline 2,50 & 1,88 & 2,38 & 2,57 & 3,31 \\
\hline 3,00 & 1,74 & 2,31 & 2,46 & 3,17 \\
\hline 4,00 & 1,74 & 2,16 & 2,33 & 3,00 \\
\hline 5,00 & 1,71 & 1,91 & 2,24 & 2,89 \\
\hline
\end{tabular}

Obs.: Foram adotadas as seguintes refletâncias do ambiente: Teto $=70 \%$; Parede $=50 \%$; Piso $=10 \%$.

Fonte: ABNT (1992)

Para efeito de classificação da edificação devem ser respeitados, além dos limites de potência instalada, os critérios de controle do sistema de iluminação, tais como desligamento automático do sistema de iluminação; divisão dos circuitos e contribuição da luz natural. Esses parâmetros possibilitam avaliar um melhor desempenho da edificação quanto à eficiência energética.

De acordo com a regulamentação, para que seja realizada a etiquetagem de ar condicionado é necessário que as edificações artificialmente condicionadas possuam aparelhos com referência e que estejam de acordo com as normas do Programa Brasileiro de Etiquetagem (PBE/INMETRO, 2013).

A classificação do INMETRO é baseada no índice de eficiência do equipamento, e pode variar de A a E. Os aparelhos de ar condicionado também são classificados e recebem etiquetagem específica, conforme os requisitos mínimos de eficiência para cada categoria (Tabelas 13 e 14). 
Tabela 13: Parâmetros de classificação para Ar Condicionado.

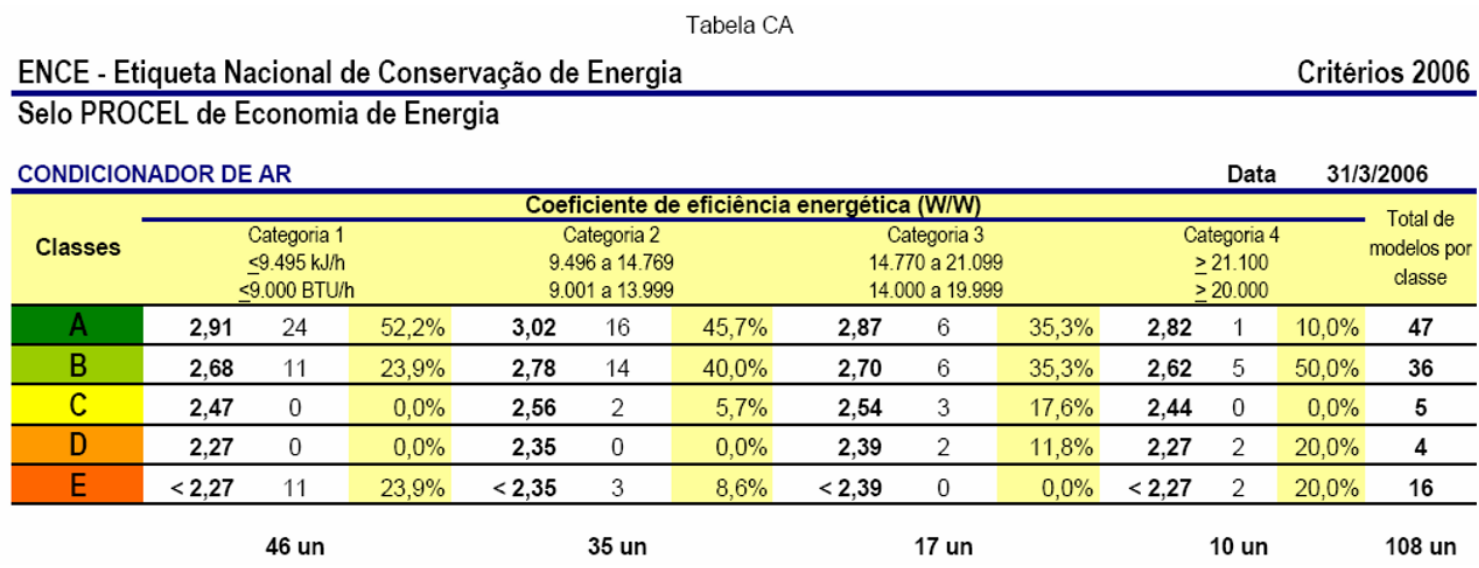

Tabela 14: Parâmetros de Classificação para Condicionador de ar tipo Split.

CONDICIONADOR DE AR SPLIT

\begin{tabular}{|c|c|c|c|c|c|}
\hline \multicolumn{3}{|c|}{ CONDICIONADOR DE AR SPLIT } & Data atualização: & \multicolumn{2}{|c|}{$31 / 3 / 2006$} \\
\hline Classes & $\begin{array}{r}\text { Coefi } \\
e\end{array}$ & $\begin{array}{l}\text { nte de e } \\
\text { gética (V }\end{array}$ & $\begin{array}{l}\text { ência } \\
\text { V) }\end{array}$ & $\begin{array}{l}\text { Total de } \\
\text { modelos por } \\
\text { classe }\end{array}$ & \\
\hline A & & CEE> & 2,94 & 59 & $26,7 \%$ \\
\hline $\mathrm{B}$ & 2,76 & $<C E E \leq$ & 2,94 & 101 & $45,7 \%$ \\
\hline C & 2,58 & $<C E E \leq$ & 2,76 & 43 & $19,5 \%$ \\
\hline D & 2,39 & $<C E E \leq$ & 2,58 & 16 & $7,2 \%$ \\
\hline $\mathrm{E}$ & & CEE $\leq$ & 2,39 & 2 & $0,9 \%$ \\
\hline
\end{tabular}

Fonte: INMETRO (2013)

Os sistemas de condicionadores de ar não regulamentados pelo INMETRO são baseados nas tabelas da ASHRAE 90.1, classificados de acordo com os níveis e requisitos a seguir, uma vez que são parâmetros internacionais de eficiência energética:

a) Para os Níveis $A$ e $B$ os condicionadores de ar, os resfriadores de líquido, os condensadores e torres de arrefecimento devem atender aos requisitos mínimos de eficiência estabelecidos pela ASHRAE 90.1 - 2004 (ASHRAE, 1997);

b) Para o Nível $\mathrm{C}$, os condicionadores de ar, os resfriadores de líquido, os condensadores e torres de arrefecimento devem atender aos requisitos mínimos de eficiência definidos na ASHRAE 90.1 - 1999 (ASHRAE, 1997);

c) Para o Nível D, os condicionadores de ar e os resfriadores de líquido devem atender aos requisitos mínimos de eficiência apresentados na ASHRAE 90.1 - 1989 (ASHRAE, 1997);

d) Nível E: quando o sistema não se enquadrar nos níveis acima.

Para alcançar o selo tipo A, o sistema de condicionamento de ar deve respeitar os seguintes requisitos: cálculo detalhado de carga térmica, controle de temperatura por zona, automação, isolamento de zonas, controles e dimensionamento do sistema de 
ventilação, recuperação de calor, controles e dimensionamento dos sistemas hidráulicos e equipamentos de rejeição de calor.

Em relação às envoltórias, o regulamento descreve o método de classificação de eficiência, baseado em um indicador de consumo obtido através de uma equação.

Foram desenvolvidas duas equações por zona bioclimática: uma representando edifícios com área de projeção (Apcob) menor que $500 \mathrm{~m}^{2}$ e outra para edifícios com área de projeção maior que $500 \mathrm{~m}^{2}$.

As equações foram desenvolvidas a partir de análises do resultado de simulações do desempenho termo-energético de protótipos cujas tipologias representam as edificações atualmente construídas no país. Os protótipos foram elaborados após um levantamento fotográfico que reuniu 1103 edificações comerciais e institucionais em cinco capitais brasileiras. O levantamento identificou as características externas das edificações tais como forma e dimensões, percentual de abertura na fachada, existência e dimensões de proteções solares e cores dos vidros (CARLO et. al., 2005), dando origem, por sua vez, a cinco protótipos, cada qual com uma volumetria distinta e representativa de uma atividade comercial: hotéis, grandes escritórios, pequenos escritórios, grande loja e pequena loja. Estes protótipos representativos foram alterados para o pior caso de cada atividade comercial encontrado no levantamento e avaliados sob diversas situações (CARLO e LAMBERTS, 2006). Em seguida, medidas de conservação de energia foram aplicadas ao protótipo pouco eficiente a fim de verificar sua relevância na eficiência energética. As medidas mais relevantes que compõem a envoltória fazem parte das equações de cálculo do Indicador de Consumo. O Indicador de Consumo referente à envoltória do edifício proposto deve ser calculado com as diferentes equações de acordo com a cidade e Zona Bioclimática onde o edifício está inserido. A seguir, como exemplo, mostra-se as equações válidas para Edificações localizadas na região bioclimática de Florianópolis:

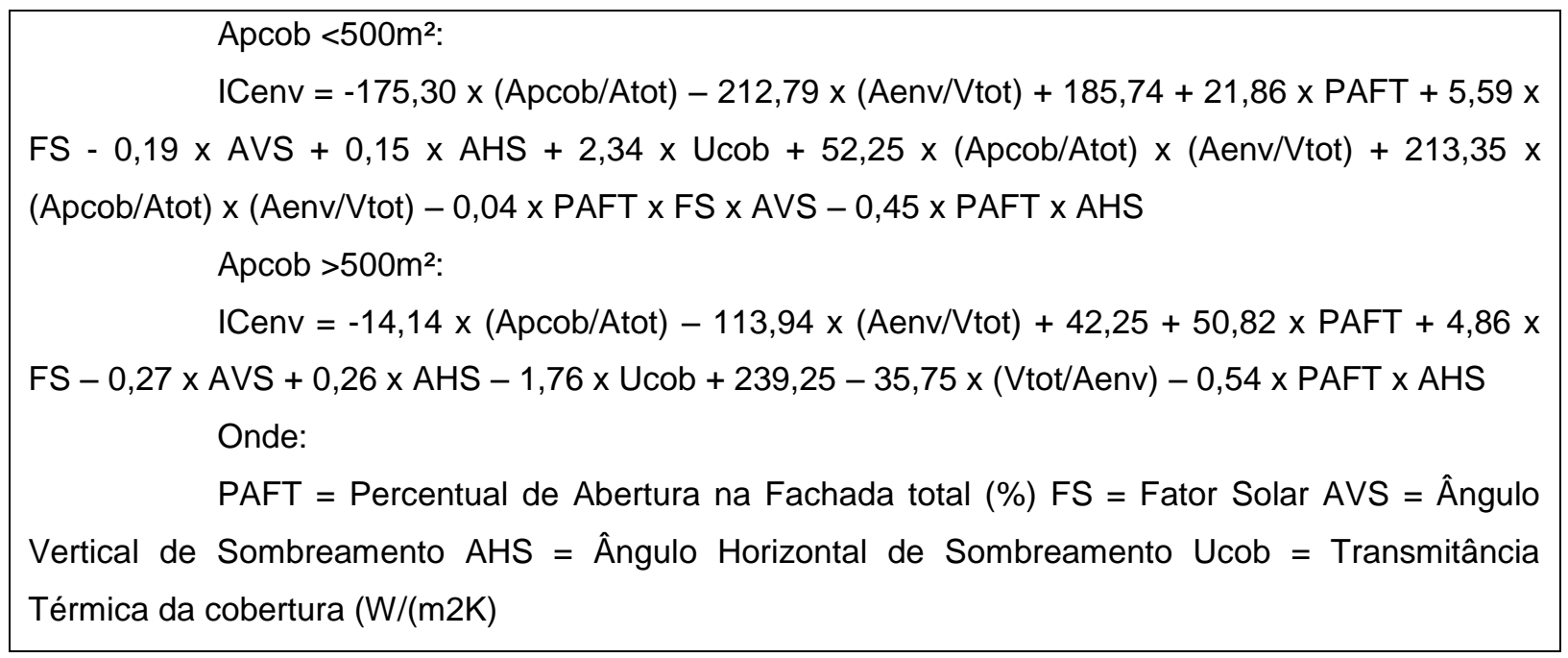

As equações para Apcob $>500 m^{2}$ são válidas para uma Atot limite. Acima deste limite, deve-se utilizar a simulação, conforme descrito a seguir. As equações são válidas 
para uma Transmitância Térmica da cobertura (Ucob) constante, igual a 2,0 W/(m2.K). O indicador de consumo obtido deve ser comparado a uma escala numérica dividida em intervalos que descrevem um nível de classificação de desempenho que varia de $\mathrm{A}$ a $\mathrm{E}$. Quanto menor o indicador obtido, mais eficiente será a envoltória da edificação. A escala numérica da classificação de eficiência é variável, e deve ser determinada para cada volumetria de edifício através dos parâmetros: razão da área de projeção da cobertura pela área total de piso (Apcob/Atot) e razão da área da envoltória pelo volume total (Aenv /Vtot ). Os demais parâmetros da equação são fornecidos.

A simulação computacional também pode ser utilizada como alternativa para a classificação do nível de eficiência e pode ser usada para avaliar edifícios condicionados artificialmente ou naturalmente ventilados, ou que tenham áreas condicionadas de longa permanência menor que a área útil total.

É obrigatório comprovar que o ambiente interno das áreas não condicionadas proporciona temperaturas dentro da zona de conforto durante $95 \%$ das horas ocupadas.

O processo de implementação de certificação passa por duas etapas: projeto e documentação, e auditoria no local, após o uso e assim pode-se emitir uma placa com o certificado.

A utilização de etiquetagem em edificações pode agregar valor para as edificações mais eficientes e auxiliar os consumidores a optarem por edificações com maior eficiência energética além de trazer um diferencial de mercado para construtores.

Para as edificações públicas, a etiquetagem pode auxiliar tanto na redução de gastos com energia elétrica como também em difundir essa prática projetual através do exemplo, melhorando o desempenho e propiciando menores custos de manutenção.

Apresentar obras eficientes para a população demonstra seriedade do governo em relação ao bom uso do dinheiro empregado. Gerar bons exemplos que futuramente poderão ser abordados também dentro do aspecto da etiquetagem de edifícios residenciais, constatando o valor agregado e a economia que este selo proporciona.

Num futuro próximo, pretende-se começar a elaboração de uma Regulamentação Voluntária para a Certificação do Nível de Eficiência Energética para Edifícios Residenciais.

\subsection{NORMA DE DESEMPENHO DAS EDIFICAÇÕES}

Com o objetivo de reestruturar o setor da construção civil, em 2008 foi publicada a NBR 15575, que define o desempenho das edificações habitacionais, conhecida por Norma de Desempenho. Desde então, a norma passou por diversas revisões e, finalmente, foi publicada em 19 de fevereiro de 2013, passando a vigorar em um prazo de 150 dias. 
Diferentemente de outras normas publicadas, essa não foi direcionada ao tipo de material ou ao sistema construtivo, e sim na capacidade de resistir às intempéries e às situações do cotidiano de uso e operação, assim como garantir o conforto para o usuário.

Pela primeira vez, uma norma brasileira associa a qualidade de produtos aos seus resultados ao consumidor, com instruções claras e transparentes de como fazer essa avaliação.

As regras privilegiam os benefícios ao consumidor e dividem responsabilidades entre fabricantes, projetistas, construtores e usuários. A norma NBR 15575 (ABNT, 2013) descreve que níveis de segurança, conforto e resistência devem proporcionar cada um dos sistemas que compõem um imóvel: estrutura, pisos, vedações, coberturas e instalações.

Essa norma contribui e impulsiona a indústria da construção, à medida que incentiva o uso da inovação no setor. Atualmente, as regras dizem respeito somente ao resultado final de uma edificação, em quais condições de uso e habitação devem ser garantidas e qualquer tecnologia pode ser usada. O importante é que a edificação atenda aos parâmetros de desempenho. Basicamente, a Norma de Desempenho está respaldada por cinco pontos, que são os sistemas que visam garantir a qualidade ao usuário final (Figura 16).

Figura 12: Cinco sistemas para Avaliação do Desempenho das Edificações

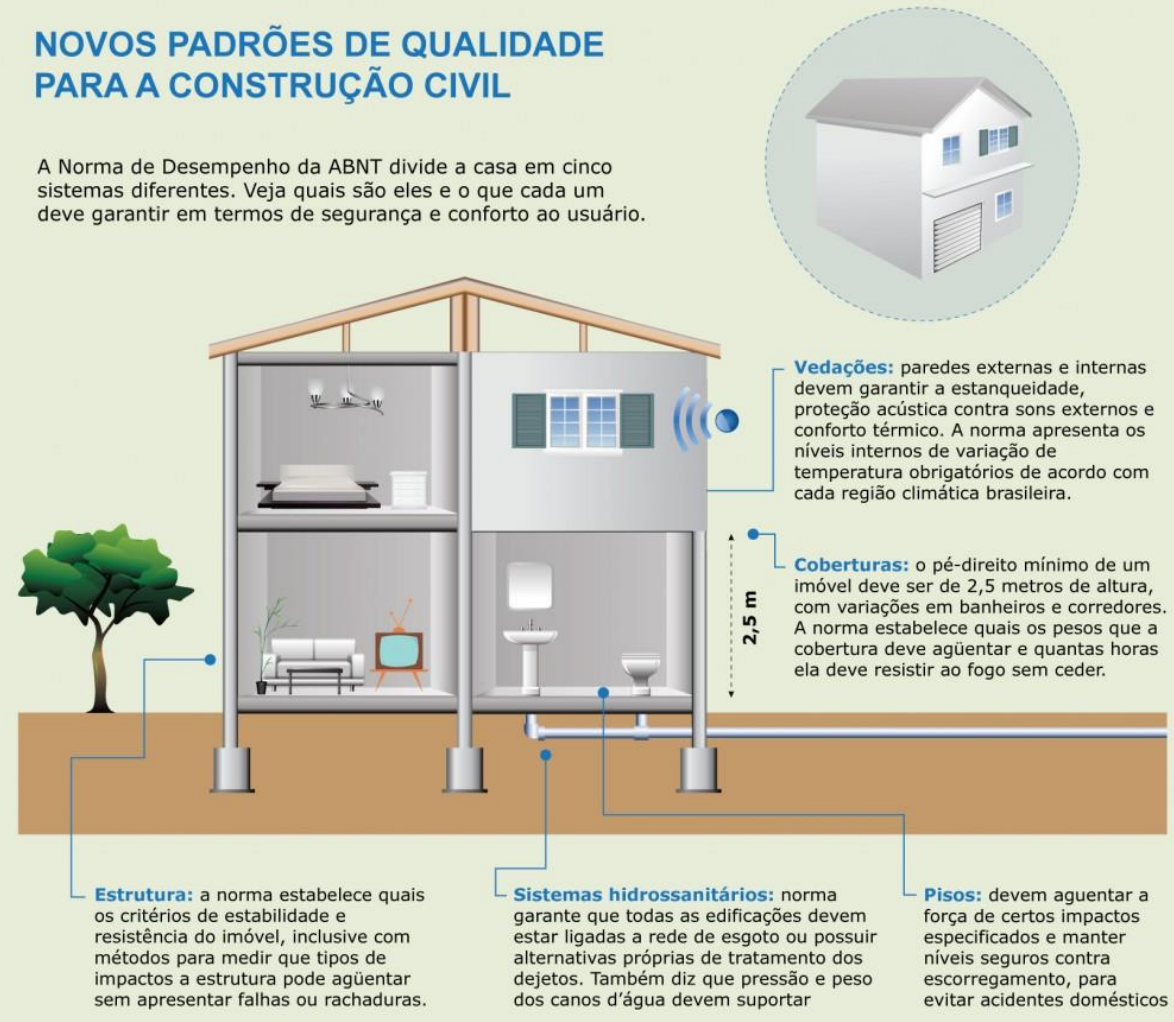

Fonte: http://www.caubr.gov.br/mudancasnormadesempenho/ . Acesso 16 set. 2016. 
A Norma de Desempenho de Edificações é dividida em seis partes: uma de requisitos gerais da obra e outras cinco referentes aos sistemas que compõem o edifício (estrutural, de pisos, de cobertura, de vedação e sistemas hidrossanitários). Para cada um deles, a norma estabelece critérios objetivos de qualidade e os procedimentos para medir se os sistemas atendem aos requisitos.

A função de cada sistema é definida pelos principais critérios de desempenho que devem cumprir. Esses critérios são especificações técnicas definidas em quantidades mensuráveis ou qualidades que possam ser objetivamente determinadas. Por exemplo, as vedações têm que reduzir a temperatura ambiente em um certo número de graus Celsius; os equipamentos sanitários devem ser resistentes à ferrugem e a roedores; a estrutura deve apresentar níveis de estabilidade e resistência.

A norma fornece instruções de testes a aplicar a cada um dos sistemas para verificar seu desempenho global. Por exemplo, no caso de desempenho estrutural das paredes, a resistência ao impacto deve ser testada jogando-se sacos de couro de $70 \mathrm{~cm}$ de altura e esferas de aço com 1,26 cm de diâmetro contra as paredes. A norma especifica inclusive a quantidade de força (em Joules) que o impacto deve produzir. O Guia Orientativo da Câmara Brasileira da Indústria da Construção (CBIC) demonstra esse conceito de forma simples, por tabelas e gráficos. Para facilitar a compreensão do leitor, classifica as exigências da Norma por funções, como desempenho estrutural, segurança no uso e na operação, segurança contra incêndio, funcionalidade e acessibilidade, desempenho térmico, desempenho acústico, estanqueidade à água e durabilidade. A intenção da CBIC, ao elaborar o guia, é fornecer um instrumento para facilitar o entendimento e a interpretação da norma por engenheiros, projetistas, construtores e usuários.

Até agora, as normas da ABNT destinadas à construção civil eram prescritivas, contendo uma série de requisitos e critérios exigidos para um produto ou procedimento específico, estabelecidos pelo seu uso consagrado ao longo do tempo. Ao contrário, a Norma de Desempenho determina as necessidades do usuário que o edifício inteiro deve atender. Enquanto normas prescritivas são quantitativas e referentes aos produtos, às partes de uma edificação, a Norma de Desempenho é tanto qualitativa como quantitativa e com ênfase ao funcionamento de sistemas inteiros, avaliando o comportamento da edificação, sua qualidade global e vida útil conforme às necessidades dos usuários.

Todas as normas continuam valendo e não entram em conflito, mas se complementam. As exigências são de tipos diferentes, mas ambas devem ser atendidas. $\mathrm{Na}$ verdade, a Norma de Desempenho é como se fosse a "norma-mãe", ou um guia remissivo para mais de 157 normas prescritivas existentes, responsável em coordenar a execução das outras, uma vez que estabelece critérios mais gerais de funcionamento. Assim, quando um fabricante produzir um azulejo ou uma placa de gesso, ele deve seguir as orientações das 
normas prescritivas, mas estar atento para os resultados de desempenho do produto, uma vez que esses resultados serão fundamentais para o projetista definir o que será usado na obra. Por causa dessa força gravitacional que a Norma de Desempenho exerce sobre as outras, ela está sendo definida como um divisor de águas para o setor da construção civil no Brasil.

A norma prevê uma série de situações de risco para o imóvel e fornece não só a medida, como também instruções de como medir se os sistemas são seguros, garantindo o bom funcionamento da edificação. Trata-se de um documento de alto nível técnico, que visa orientar fabricantes de materiais, projetistas e construtores e, também, os usuários.

A intenção da norma é apresentar parâmetros de projetação que garantam para os usuários um mínimo de conforto ambiental e, em relação, às manutenções, responsabilizando construtores e projetistas, em que o usuário, respaldado pela legislação, possa recorrer à justiça caso venha a ter algum problema que seja relacionado aos sistemas especificados pela norma.

A legislação brasileira reconhece a ABNT como entidade responsável por determinar padrões mínimos de qualidade para produtos e serviços realizados no Brasil. Dessa forma, as normas da ABNT são o principal critério usado pela justiça brasileira em decisões dessa ordem. A Norma de Desempenho não fornece penalidades ou multas para quem descumpri-la, apenas os critérios mínimos exigidos para se determinar objetivamente a qualidade de produtos e serviços e medir a qualidade do ambiente construído. Mas é consenso entre os especialistas que se trata de uma arma de defesa do consumidor contra práticas enganosas. Assim que o consumidor verificar um problema em seu apartamento ou casa, ele pode contratar um engenheiro para fazer um laudo dizendo se o imóvel está ou não dentro dos critérios estabelecidos pela ABNT. Como a norma fornece também os testes a serem feitos para garantir a qualidade, espera-se que qualquer laudo produza resultados semelhantes. Assim, o juiz terá critérios objetivos para definir as responsabilidades nesses casos. O documento também serve como garantia para construtoras, que vão identificar mais facilmente em que fase do processo o problema se originou, se a falha está no produto, no projeto, na execução ou na falta de manutenção, identificando os responsáveis.

Infelizmente a NBR 15575 está sendo implementada, como já diz sua própria nomenclatura, somente para edificações residenciais. As edificações comerciais, industriais e públicas não são contempladas. Deve-se obedecer como parâmetro de projetação para edificações públicas, somente o sistema de etiquetagem que exige selo A para projetos de edificações públicas de qualquer natureza.

Entretanto, o sistema de etiquetagem trata-se de uma avaliação muito restrita, avalia somente os aistemas de ar condicionado, sistemas elétrico e a envoltória com já foi dito anteriormente. 
Tentar abranger a NBR 15575 para as edificações públicas significa também oferecer critérios de qualidade e durabilidade para um setor de construção que ainda entrega produtos de baixa qualidade para o Contratante, no caso a esfera pública.

$\mathrm{Na}$ maioria das vezes, a presença de um Contratante-pessoa física, além de demonstrar maior cobrança e credibilidade na figura do cliente, reforça a figura de um cliente que poderá eventualmente, num futuro próximo trazer um dissabor que pode advir de uma insatisfação pessoal, de gosto, pessoal ou técnica que atrapalhe o contratado no mercado em geral. Um cliente satisfeito trará novos clientes e um cliente insatisfeito poderá acarretar um processo judicial ou em alguma conciliação em relação à edificação, e em uma péssima imagem perante o mercado consumidor.

A figura da gestão pública não passa essa credibilidade. Contrariamente, no papel de cliente, as instâncias governamentais são vistas pelo número de "obras sem dono", em que projetos não são detalhados ou especificados adequadamente e licitações são superfaturadas e propinas são pagas de maneira corriqueira. De maneira geral, podemos dizer que isso ocorreu de maneira disseminada nas obras e projetos públicos. As licitações são destinadas e elaboradas de acordo com a intenção de obras e financeira de empresas específicas, deixando a imparcialidade de fora. Sabemos que órgãos regulamentadores existem para fazer este tipo de fiscalização, no entanto com papel limitado perante a grande quantidade de ilegalidades.

A Norma de Desempenho pode acarretar numa mudança de cultura e de comportamento na construção civil na área habitacional, passando pelos processos de criação, edificação e manutenção, que terão que ter um olhar mais criterioso, desde a concepção, passando pela definição de projeto, elaboração de plano de qualidade do empreendimento e de um manual abrangente de operação, uso e manutenção da edificação, contendo as informações necessárias para orientar essas atividades, na espera de uma produção mais qualificada.

O fato da NBR 15575 estabelecer critérios de qualidade e de uso e operação gera uma nova movimentação em relação aos custos de financeiros, físicos, tecnológicos entre outros, na vida da edificação. Em consequência, contribui no debate quanto ao papel do gestor, do usuário, no aumento e na qualidade de vida da edificação em funcionamento.

Ela estabelece padrões mínimos de qualidade, baseados no desempenho e na durabilidade dos sistemas. Isso serve como balizador para o mercado de construção civil, que atua em um mercado mais regulado, e segurança jurídica para os consumidores. A norma possui critérios objetivos para medir as responsabilidades em caso de problemas. $O$ critério de desempenho é utilizado largamente em edificações dos países desenvolvidos há mais de 30 anos. Com a edição da Norma ABNT 15.575, o Brasil dá o primeiro passo para massificar esses padrões de qualidade em todo o seu território. 


\subsection{BIM - A REVOLUÇÃO DAS FERRAMENTAS COMPUTACIONAIS}

Building Information Modeling ou Modelagem da Informação da Construção (BIM) é de acordo com Eastman et al. (2008, p.13) "[...] uma tecnologia de modelagem e um grupo associado de processos para produção, comunicação e análise de modelo de construção". O conceito BIM envolve tecnologias e processos que devem ser usados na produção, comunicação e análise dos modelos de construção. Tem por meta buscar uma prática de projetos integrada, num sentido em que todos os participantes da indústria da engenharia, arquitetura e construção (AEC) convertam seus esforços para a produção de um modelo único de edifício. A utilização do BIM pode ter um papel decisivo na melhoria das fases do projeto, auxiliando na geração de propostas coerentes com as solicitações dos clientes, na integração dos projetos, entre si, com a construção e sua manutenção, na redução do tempo e no custo da construção, aumentando sua vida útil.

Duas principais tecnologias presentes no BIM o diferenciam dos sistemas de CAD tradicionais, são elas: modelagem paramétrica e interoperabilidade. A primeira permite representar os objetos por parâmetros e regras associados à sua geometria, assim como, incorporar propriedades não geométricas e características a esses objetos. Além do mais, modelos de construção baseados em objetos paramétricos possibilitam a extração de relatórios, checagem de inconsistências de relações entre objetos e incorporação de conhecimentos de projeto, a partir de modelos. A interoperabilidade é uma condição para o desenvolvimento de uma prática integrada. Esse uso, com equipes de colaboração, é possível com a integração da informação entre os aplicativos computacionais, utilizados por diferentes profissionais durante a fase do projeto.

Aplicativos computacionais, que empregam o conceito de modelos paramétricos, permitem ao projetista a possibilidade de explorar diferentes alternativas de soluções de projeto de forma rápida e segura. Novos objetos podem ser criados e reconstruídos sem necessitar apagar ou criar outro objeto. Além do mais, objetos com formas geométricas complexas, que outrora eram de difícil manipulação, podem ser transformados em modelos paramétricos.

A capacidade de alguns aplicativos BIM na geração de modelos paramétricos possibilita a criação de novas famílias de objetos para arquitetura. Com isso os projetistas podem criar novas formas, não existentes nos aplicativos BIM comercializados. As novas famílias criadas em um determinado projeto poderão ser inseridas em quaisquer outros projetos e poderão fazer parte do repertório dos projetistas. 
Enfrentam-se atualmente alguns problemas que impedem a consolidação do BIM ou, até mesmo, que clientes e profissionais conheçam o programa e seus avanços (Figura 17).

Figura 13: Atuais problemas enfrentados para adoção da plataforma BIM na construção civil.

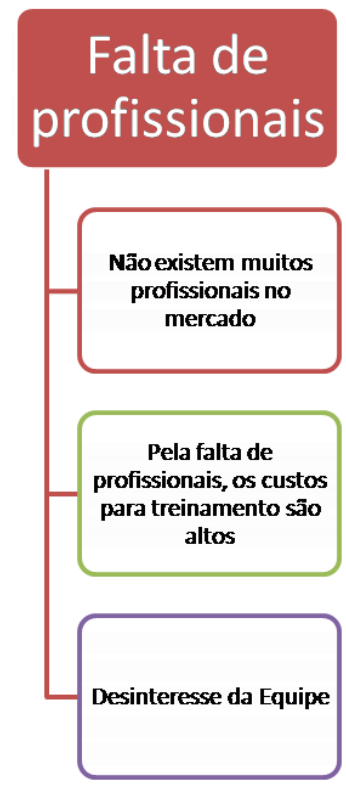

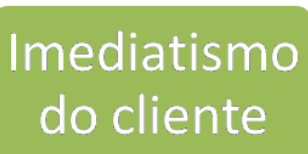

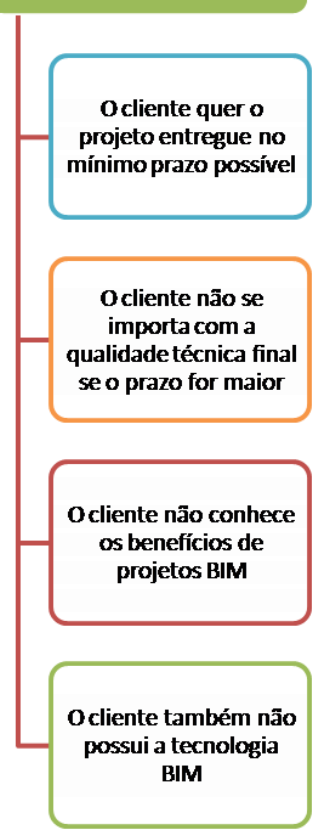

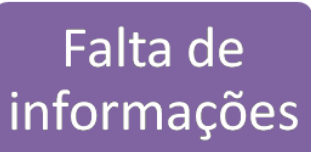

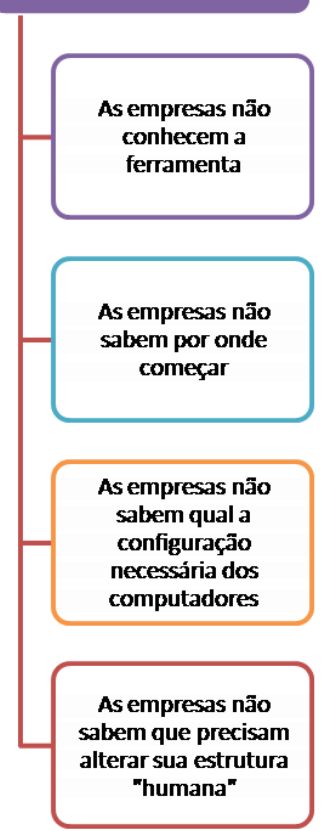

Fonte: https://medium.com/@revitse/bim-introdu\%C3\%A7\%C3\%A3o-d33d37f9ad91\#.q72m17cx7. Acesso 31 ago 2016.

Lidamos, inicialmente, com a falta de profissional qualificado, a resistência dos profissionais na mudança de modelo operacional, assim como ocorreu anos atrás com a inserção do AutoCad no processo de projetação. Os profissionais, que antes utilizavam desenhos sem a utilização de computadores, criticavam o programa com receio que o processo de trabalho fosse alterado e que isso alteraria a qualidade do produto final e agregaria grandes custos durante o processo de inovação. Com o BIM, não é diferente, os cursos são caros, o investimento em equipamentos acarreta custos extras para os escritórios.

Em relação aos clientes, podemos perceber que o prazo fala mais alto que o valor projetual. Vivemos em uma sociedade imediatista, em que não se calcula que o maior tempo gasto na produção de projetos será recuperado durante o processo de construção, evitando alterações e adaptações, além de menos custos durante a fase de execução. As informações existentes sobre o BIM, para o cliente comum, são ainda supérfluas, não proporcionando suporte técnico que direcione a escolha do escritório de acordo com o programa utilizado ou pela qualidade do produto final. 
A grande maioria dos escritórios, assim como os clientes, ainda não conhecem a ferramenta. Os escritórios que conhecem os benefícios da ferramenta não conhecem o caminho que leva ao BIM, não sabem por onde começar, pois alterar a ferramenta de trabalho não significa alterar somente as configurações das máquinas, reflete também em qualificar a equipe, reorganizar os processos de trabalho. É necessária uma conscientização do setor da construção civil para que essas ferramentas sejam inseridas no cotidiano e, juntamente, com os avanços com sistemas de etiquetagem e com a Norma de Desempenho, proporcionem melhor qualidade ao ambiente construído.

$O$ processo do projeto envolve muitas fases e diferentes participantes que necessitam de trocar informações ao longo do seu ciclo de vida. Cada atividade e especialidade utilizam tipos diferenciados de aplicativos computacionais, que precisariam ser interoperáveis. A interoperabilidade é a capacidade de identificar os dados necessários para serem passados entre os aplicativos (EASTMAN et. al., 2008). Com a interoperabilidade a necessidade de réplica de dados de entrada é eliminada e facilita, de forma automatizada e sem obstáculos, o fluxo de trabalho entre diferentes aplicativos, durante o processo de projeto.

Para a consolidação do uso do BIM é interessante conhecer seus estágios de desenvolvimento. Tobin (2008) classifica o BIM em três gerações, BIM 1.0, BIM 2.0 e BIM 3.0. Conhecer esses estágios ajuda a identificar o estágio em que o Brasil se enquadra no ramo de pesquisas e no uso no setor da construção civil.

A era BIM 1.0 representa o trabalho da maioria dos escritórios que trabalham com BIM. A substituição gradativa de software CAD tradicional, permite aos projetistas maior capacidade de coordenação dos documentos, adição de informações aos objetos e rápida produção de documentos, tornando o arquiteto o coordenador de um projeto tridimensional gerando maior produtividade, qualidade no projeto, redução de custos e maior controle das informações. No entanto, a atividade projetual ainda permanece isolada. O BIM aparece mais como uma ferramenta do que um processo de trabalho fundamentado na cooperação de diferentes organizações profissionais.

A era BIM 2.0, a interoperabilidade e a colaboração tornam-se essenciais na atividade de projeto. O uso do BIM permite centralizar o controle e o fluxo das informações que devem ser utilizadas no processo de planejamento e produção do edifício. Representa o início de uma mudança significativa para o processo de projetação, utilizando aplicativos que permitem a revisão, análise e a avaliação de soluções de projeto de forma automática. Assim, o processo de síntese e de avaliação torna-se mais dinâmico e mais rápido, além de ocorrer nas etapas iniciais do processo de projeto. Embora seja nessa etapa que se começa a usufruir dos benefícios dos BIM, esse processo ainda não está consolidado no cenário internacional e, muito menos, no nacional. 
A era BIM 3.0 é caracterizada por trabalhos em equipes multidisciplinares que utilizam modelos integrados, cujos fluxos de informação devem acontecer de forma contínua, sem perdas e sem sobreposições. Os diferentes profissionais de projeto e construção irão construir um "modelo único" para um propósito coletivo que é a construção virtual do modelo do edifício.

O BIM oferece aos projetos, projetistas e envolvidos no projeto, atividades e aplicativos ainda inimagináveis no exercício da projetação. Além de todas as qualidades já citadas, a modelagem tridimensional também propicia visualizar a volumetria, verificar os impactos de incidência solar, quantificar e qualificar o material aplicado, observando e ajustando variáveis de conforto ambiental e outros aspectos associados. Por meio de simulações é possível a análise do desempenho térmico, sistematizando diversas abordagens em todas as fases do projeto arquitetônico.

Durante o processo de conhecimento da ferramenta BIM, o tempo gasto no fluxo de trabalho inicial e tempo são maiores do que em projetos realizados em AutoCad. Estimase que 50 a $80 \%$ do tempo de trabalho em um projeto desenhado no BIM seja consumido no processo de desenho, deixando um tempo bem reduzido para as etapas de documentação e coordenação (Gráfico 12). Ao comparar os dois sistemas, o tempo de finalização do projeto acaba sendo superior que o tempo de finalização em BIM.

Gráfico 12: Comparação entre o tempo de projeto, documentação e coordenação em AutoCad e BIM.

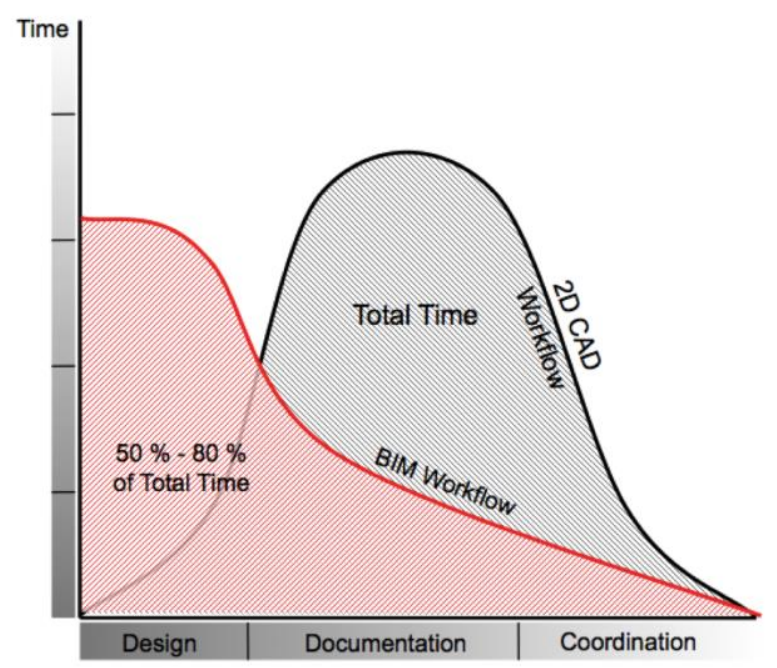

Fonte: http://www.infor.pt/open-bim. Acesso 31 ago 2016.

Apesar de o tempo de desenho do projeto em AutoCad ser consideravelmente menor que o tempo de desenho em BIM, pode-se perceber que o tempo de documentação e coordenação é muito superior que o tempo gasto no BIM, demonstrando que o BIM é mais benéfico quanto ao tempo, ao contrário do que pensa a maioria dos projetistas, clientes e empresas. 
Outro item que pode ser abordado com maior facilidade nos projetos desenhados pelo BIM é o conforto ambiental da edificação através das simulações. A busca do bom desempenho térmico das construções deve estar diluída nas diversas etapas da projetação arquitetônica, partindo da escala macro, representada pelo meio urbano, para a escala micro, correspondente aos ambientes da edificação.

Os estudos preliminares preveem o levantamento do programa de necessidades, das condicionantes climáticas e características geográficas e urbanísticas do ambiente onde se insere. As condicionantes climáticas se baseiam em normais climatológicas que caracterizam o comportamento dos elementos climáticos ao longo do ano, a saber, a temperatura do ar e radiante, a umidade relativa, os índices pluviométricos e a ventilação. Isso indica, em linhas gerais, as diretrizes de projeto para adequação da edificação ao clima do lugar, que, por sua vez, devem se alinhar ao uso da edificação, assim como às restrições legais. É desejável que se possa prever horizontes futuros baseados na lei de ordenamento e uso do solo de cada lugar, em específico.

Todas essas informações estabelecem os parâmetros que influenciam o processo criativo do arquiteto. Na fase de esboço, a implantação, a orientação e a volumetria do edifício influenciam no grau de exposição ao sol de toda a sua envoltória, assim como do potencial de distribuição de pressão dos ventos nas fachadas, levando em consideração a frequência de incidência da ventilação, assim como as interferências do entorno. Durante o desenvolvimento e detalhamento do projeto, são configurados os diversos ambientes da edificação, definidas as suas dimensões, aberturas e materiais empregados nos componentes construtivos. Essas decisões projetuais influenciam diretamente o desempenho térmico de cada ambiente, que deve estar de acordo com as atividades a serem realizadas, quantidade de ocupantes e período de ocupação.

Atualmente muitos programas de simulação computacional já estão sendo desenvolvidos com o intuito de tornarem-se mais acessíveis aos usuários, ampliando as oportunidades de avaliação de desempenho.

Existem diversas possibilidades de utilização de ferramentas computacionais, em vários níveis de complexidade, que podem ser aplicadas nas diversas fases do projeto arquitetônico, tais como recomendações ou estratégias de projeto, análises de incidência solar, simulações de comportamento termo-energético, análises de ventilação, entre outros.

Porém, a maior parte dessas ferramentas está distante do cotidiano de escritórios de arquitetura, restritas aos especialistas do setor. Além disso, há muita resistência por parte dos projetistas em utilizar ferramentas de avaliação, principalmente aquelas que tratam das variáveis apenas por valores numéricos. Como consequência, as avaliações acontecem de maneira isolada e estanque, nem sempre integradas ao processo de projeto, desvinculadas das demais questões envolvidas. 
Essa falta de integração da simulação computacional, para avaliação do desempenho térmico, durante o processo projetual consiste numa barreira para a aceitação dessas ferramentas na prática arquitetônica. Os complexos programas, que precisam ser alimentados com uma grande quantidade de variáveis, tendem a se distanciar do processo da criação arquitetônica, principalmente nas fases iniciais, nas quais o enfoque é a forma e a orientação da edificação. Os aspectos negligenciados nas primeiras etapas dificilmente poderão ser corrigidos nas fases posteriores, quando se torna inviável realizar modificações significativas no projeto. Com isso, geralmente as simulações são realizadas apenas para testar a proposta final, levando ao uso tardio da avaliação de desempenho, que se limita a apontar o sucesso ou fracasso de todo o processo (CUNHA, 2010).

Quanto às estratégias de projeto, os estudos de Givoni (1992), indicam nove para edificações condicionadas naturalmente. O software Analisis Bio 2.1 (LAMBERTS et. al., 2003) apresenta uma versão da carta bioclimática que plota dados de temperatura relativa. A ideia é cruzar os dados de temperatura do ar e umidade relativa de uma determinada localidade para a obtenção de informações de estratégias a serem adotadas no projeto em busca de um maior conforto térmico.

Programas que tratam da incidência solar são precisos e fáceis de serem visualizados. O Programa Sketch UP, por exemplo, permite de maneira simples que seja feita uma análise da incidência solar desde a etapa de estudo preliminar por meio de uma modelagem mais simples. Essa visualização possibilita avaliar o potencial de ganho solar através da sua envoltória, auxiliando na tomada de decisões quanto ao posicionamento, e configuração das aberturas, assim como a escolha dos materiais adequados, sendo uma ferramenta de simulação de fácil acesso (Figura 18). 
Figura 14: Fachada renderizada no Sketch Up - incidência solar.

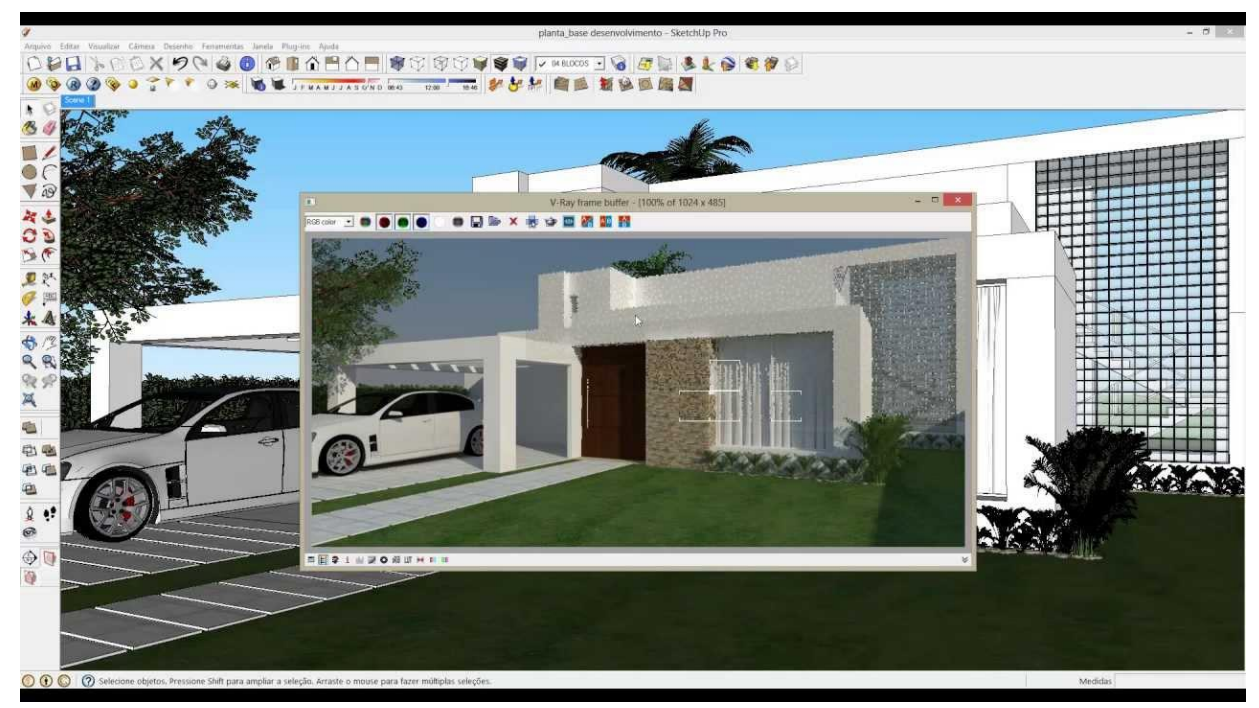

Fonte: https://www.youtube.com/watch?v=-YX1KcsubrE . Acesso 10 set. 2016.

Em comparação aos softwares de simulação solar, os de simulação termoenergética não são nem precisos nem de fácil entendimento. O Energy Plus, por exemplo, desenvolvido pelo Departamento de Energia dos Estados Unidos, é uma grande ferramenta para a simulação do desempenho térmico, com grande aceitação no Brasil. O programa consegue analisar as cargas térmicas em componentes construtivos, possibilitando a verificação do desempenho térmico de diferentes tipologias de construções.

De maneira semelhante, aos programas de simulação termo-energética, a análise do comportamento da ventilação natural não é de fácil compreensão e carece de métodos compatíveis com o processo projetual, principalmente no que se refere à quantificação do impacto das decisões tomadas nas diversas fases de elaboração do projeto. Geralmente, a abordagem realizada, a respeito da ventilação, é vista somente em abordagens sobre ventos predominantes e o dimensionamento das aberturas está mais condicionada a códigos de obras ou às normas de desempenho. Essas abordagens são superficiais, em virtude da necessidade de restringir as variáveis que influenciam na ventilação, minimizando a complexidade das avaliações.

Conhecer a distribuição da pressão exercida sobre a envoltória da edificação é imprescindível para auxiliar na escolha da orientação e posição mais adequada para localização das aberturas nas fachadas. Esses dados podem ser quantificados, pelo coeficiente de pressão, obtido através de tabelas, gráficos, equações simplificadas ou até mesmo, pela simulação computacional.

A simulação computacional baseada na dinâmica dos fluidos (Computational Fluid Dynamics - CFD) é outra abordagem passível de aplicação para auxiliar na predição no desempenho da ventilação no edifício (Figura 19). Entretanto é um método que ainda exige conhecimento técnico e experiência do operador para sua plena utilização. 
Figura 15: Simulação Computacional da dinâmica dos ventos

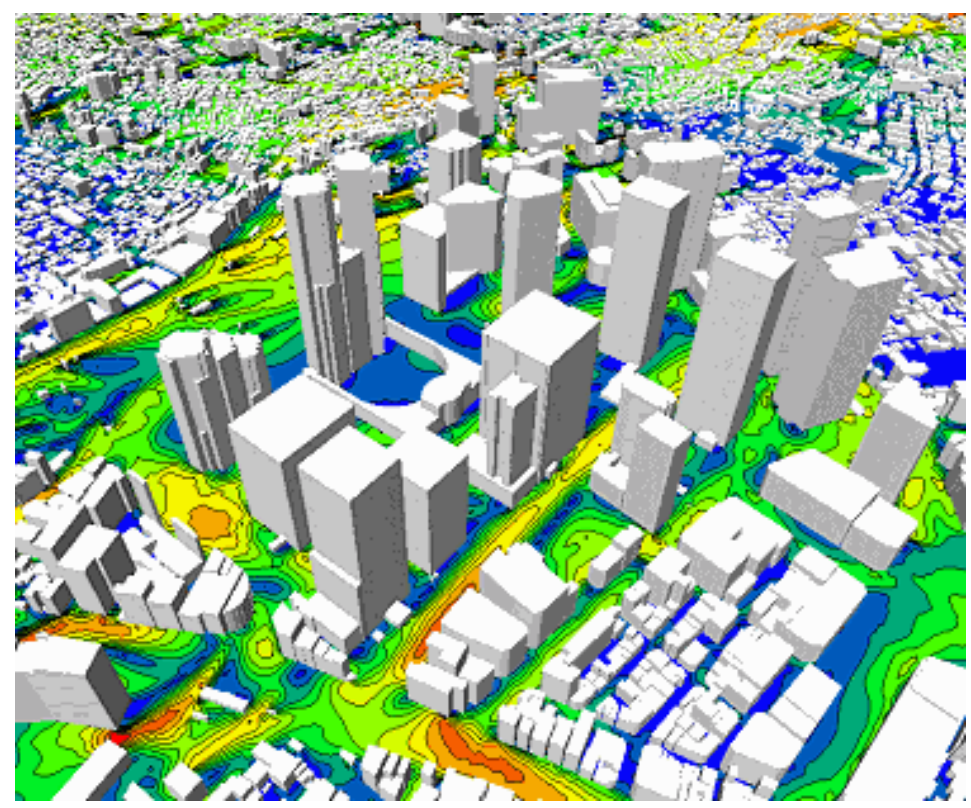

Fonte: http://www.aij.or.jp/jpn/publish/cfdguide/index e.htm. Acesso 10 set. 2016.

Essa grande evolução na tecnologia de projetação promove para a indústria da construção civil um novo olhar sobre o ciclo de vida das edificações, trazendo à tona um modelo de projeto que permite articulação e interoperabilidade de diversas áreas intervenientes.

Em um momento que o setor da construção enfrenta uma série de dificuldades, que a construção de novos edifícios perde o espaço no mercado, a manutenção e a reabilitação do patrimônio ganha cada vez mais importância. A ascendência do BIM é também de grande avanço no sistema de Gestão da Manutenção de Edifícios, permitindo um melhor gerenciamento e manutenção das edificações já existentes.

Um projeto multidisciplinar unificado possibilita um sistema de gestão e manutenção e é um grande desafio, uma vez que é necessário inserir esse modelo tridimensional no período pós obra, na etapa de vida e uso da edificação, transferindo ganhos significativos em termos de eficácia e eficiência, como uma constante na avaliação de desempenho do ambiente construído em toda sua vida útil (Figura 20).

A gestão das instalações é um campo multidisciplinar, muitas vezes associada à administração de edifícios públicos, como escolas e hospitais, ou privados como hotéis. Cada instalação está adaptada a diferentes tipos de necessidades, logo, a gestão de edifícios terá de se adaptar a cada caso. O gestor de instalações é o coordenador entre várias disciplinas de determinado edifício e serviços associados. O gestor é responsável pelas decisões em relação às infraestruturas. Os gestores têm que operar em dois níveis: Tático-Estratégico e Tático-Operacional. 
Figura 16: Equipe multidisciplinar e sistema BIM

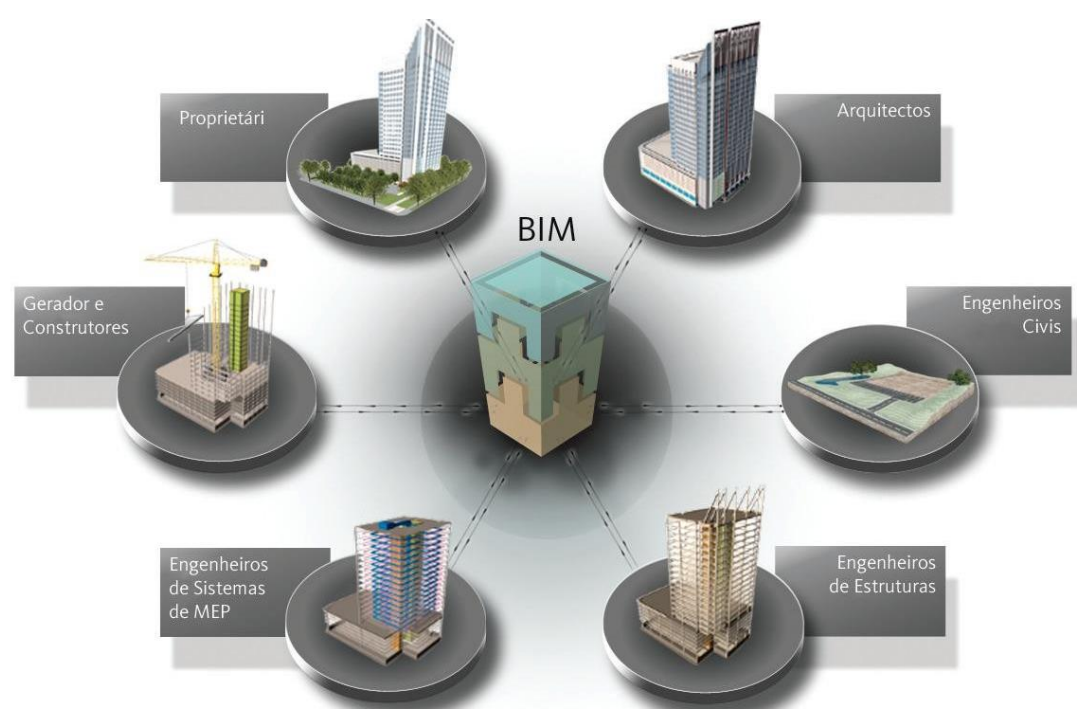

Fonte:http://pmkb.com.br/artigo/tecnologia-bim-uma-nova-forma-de-fazer-engenharia-e-arquitetura/. Acesso 31 ago 2016.

Atualmente a gestão de edifícios trata-se de um negócio bastante competitivo, tendo como objetivo a redução de custos e o aumento do valor dos serviços prestados. Apesar de ser um ótimo investimento para manutenção e aumento da vida útil das edificações, os moldes de atuação ainda não se encontram muito bem definidos no mundo. $\mathrm{Na}$ Europa, há esforços por parte de entidades competentes para tornar essa atividade, uma atividade profissional. De acordo com Kelly (2009), o valor de mercado no Reino Unido é de cerca de 100 Milhões de Libras e a tendência é aumentar, e podemos perceber que estamos diante de um mercado em ascensão.

O gestor tem a responsabilidade de prever o impacto de qualquer decisão relativa à gestão da instalação em causa, de modo a causar o mínimo impacto possível, tanto nos serviços do edifício como aos clientes. A gestão e previsão são feitas com base nas seguintes áreas: segurança ocupacional e saúde, segurança contra incêndio, segurança, manutenção, limpeza, operações, gestão de prioridade, plano de continuidade do negócio, mudança e alocação de espaço. (BOOTY, 2009)

Existem diversos benefícios na implementação de processos e ferramentas BIM no setor da AEC. Ferramentas que tornam possível a redução de custos de construção, aumento na qualidade informativa sobre o projeto e integração de projetos de diferentes especialidades, redução de erros associados à alteração de objetivos, aumento na interoperabilidade e atuação em todo o ciclo de vida do projeto. (HOWARD, 2008)

A ligação entre a gestão e o BIM não é necessária, no entanto, resulta num ganho de valor inicialmente não no aspecto financeiro, mas no aspecto tecnológico e somente por ventura mais tarde, num ganho financeiro. Trata-se de um novo modelo de trabalho, que permite uma ligação entre todas as fases do ciclo de vida do projeto, havendo menos perda de informação desde a sua concepção até a sua destruição. 
No entanto, isso é desejado para um cenário ideal, onde o edifício é feito com o propósito e onde tudo é planejado desde o começo da sua concepção. Executar a gestão de manutenção em edifícios antigos e onde nem sequer houve um plano sobre o que viria a ser a infraestrutura torna-se impossível. Para se realizar modelagem dos edifícios existentes e realizar o sistema de gestão de manutenção é necessário que o edifício tenha um projeto as built muito bem realizado.

Existe uma enorme quantidade de entraves ligada à gestão de manutenção e ao BIM, tais como: falta de um modelo 3D parametrizado, falta de plantas em CAD para posterior criação de modelo BIM 3D, falta de informação sobre os diversos materiais e equipamentos do edifício e falta de informações sobre manutenções realizadas. A partir do momento que essas barreiras são ultrapassadas, é possível ter um modelo 3D do edifício e todas as informações necessárias e relevantes para o desenvolvimento do sistema de gestão do edifício, uma vez que se pode alimentar e sistematizar os dados relativos à vida útil do edifício e as necessidades de manutenções ou alterações que possibilitem melhor desempenho ambiental.

Existe um grande número de aplicações comerciais que auxiliam o desempenho da gestão de instalações, adaptadas às necessidades e à realidade de cada empresa. É possível selecionar alguns softwares de gestão de manutenção, mas percebe-se que, geralmente, as empresas desenvolvem seu próprio software de acordo com suas próprias necessidades. Encontramos no mercado diversas aplicações específicas para serviços hospitalares, hoteleiros, mas na maioria são softwares destinados à reposição de estoque. Na maioria, são software de dados que auxiliam na organização predial, mas não transferem essa informação para um modelo 3D e, muito menos, sua interoperabilidade.

Nesse caminho, de organização e economia de manutenção, a automação predial associada ao sistema BIM pode trazer para a edificação conforto, segurança e economia, por meio da comunicação edifício-máquina-gestor-usuário.

Os índices de consumo podem ser conferidos por dados informatizados sobre iluminação, ar condicionado, combate a incêndio, segurança, controle de acesso, comunicação, gestão de insumos, entre outros.

Residências, hotéis, indústrias podem ter além de economia real, uma edificação viva, que irá ultrapassar as datas médias de vida útil de edificações consumindo menos recursos, proporcionando ao usuário um ambiente sustentável e com alto desempenho em relação a qualidade ambiental.

Em relação ao uso do BIM em projetos de arquitetura, Souza et al. (2009) descreve que os escritórios de projetos podem obter melhor qualidade de projeto, menos erros, facilidade de modificação de projeto, diminuição no prazo de entrega, redução da carga horária por projeto, maior facilidade na apresentação do projeto e maior complexidade 
nos projetos trabalhados, maior acerto em relação ao uso de materiais adaptados ao clima local, maior acerto em relação a incidência solar, ventilação e iluminação natural, aquecimento das edificações. Em suma, é possível adequar o projeto às diversas fases desde a concepção à sua execução, controlando melhor as alterações e necessidades visando melhor desempenho e vida útil prolongada do ambiente construído.

Implementar o uso do BIM nos projetos de edificações de saúde traria grande avanço econômico, ambiental e sustentável para o Brasil. Como podemos perceber, para que isso ocorra há a necessidade de se implementar um sistema que permita operação por vários atores. Esse resultado depende primordialmente da fase inicial da projetação, ou seja, grande parte do custo humano, operacional e financeiro a ser utilizado no futuro é de responsabilidade do projetista, neste caso, autor do projeto, o arquiteto.

\subsection{PROCEDIMENTOS DE MANUTENÇÃO EM EAS}

A manutenção predial preventiva vem cada vez mais ganhando espaço no mercado imobiliário brasileiro. No entanto, essa prática ainda não é tão comum quanto em outros mercados internacionais, e conscientizada dentre os usuários quanto para outros bens, como automóveis e equipamentos eletrônicos. Após aprovação da NBR 5674 (ABNT, 1999) que trata dos procedimentos de Manutenção de Edificações, pouco foi desenvolvido no meio técnico sobre manutenção predial e seus benefícios. Porém, após a implantação da nova norma de desempenho NBR 15.575 (ABNT, 2013) e do início da revisão da própria NBR 5674 (ABNT, 1999) e da NBR 14.037 (ABNT, 1998), a indústria da construção iniciou uma evolução dos estudos dessa atividade no Brasil.

Segundo a NBR 5462 (ABNT, 1992), a manutenção é uma prática que envolve ações técnicas e administrativas que, juntas, permitem manter ou devolvem a um item a capacidade de desempenhar determinada função. A NBR 5674 (ABNT, 1999) define como "[...] manutenção predial o conjunto de atividades a serem realizadas para conservar ou recuperar a capacidade funcional da edificação e de suas partes constituintes de atender as necessidades e segurança de seus usuários”. Entretanto, existem quatro tipos de processos de manutenção, conforme aponta Gomide et. al. (2006), a saber:

1) Preditiva: é a atividade de inspeção que visa o estudo de sistemas e equipamentos a fim de prever possíveis anomalias ou falhas nos mesmos, baseado no seu desempenho e comportamento, e, a partir disso, implementar e direcionar os procedimentos de manutenção preventiva;

2) Preventiva: é a atividade que entra em ação antes que haja a necessidade de reparo. Exige uma programação, com datas preestabelecidas obedecendo a critérios 
técnicos determinados pelo fornecedor ou fabricante do produto. É fundamental que haja o registro de todas as atividades executadas;

3) Corretiva: é a atividade que visa à reparação ou restauração de falhas ou anomalias, seja ela planejada ou não. Implica, necessariamente, a paralisação total ou parcial de um sistema. É o tipo de manutenção que apresenta os custos mais elevados de execução;

4) Detectiva: é a atividade que visa identificar as causas de falhas e anomalias, auxiliando nos planos de manutenção, com o objetivo de atacar a origem do problema, e não apenas o sintoma do mesmo.

Por sua vez, a NBR 15575 possui parâmetros importantes em relação ao uso adequado das edificações e versa sobre a correta manutenção das edificações. Segundo a norma, cabe aos construtores a elaboração de manual de uso, operação e manutenção que atenda à NBR 14037 (ABNT, 1998) e à NBR 5674 (1999), e que deve ser entregue aos proprietários. Esse manual, como a norma atende ainda somente edificações residenciais, deve conter informações sobre uso e manutenção de áreas comuns também.

Pela norma, a vida útil de uma edificação é definida pelo período de tempo que em que é utilizada considerando as fases as atividades para qual foi projetada e construída e a correta execução dos processos de manutenção, que devem constar em manuais específicos de uso, operação e manutenção.

O plano de manutenção interfere diretamente na estimativa da VU da edificação, sendo necessário obedecer corretamente os prazos determinados para esta ação (Gráfico 13). Ao elaborar o manual de uso, garante-se por parte dos construtores, a qualidade da execução e a entrega de um produto com critérios claramente estabelecidos. Por outro lado, quando os clientes não obedecem às manutenções indicadas nesse, em muitos casos, o proprietário fica impossibilitado de recorrer em algum processo conciliatório ou na justiça contra o executor da obra. Nesse caso, segundo o artigo 12 do Código de Defesa do Consumidor (CAMPOS e VARGAS, 2015 p. 3-4) determina que a reparação pelos danos causados aos consumidores por defeitos de projeto, fabricação, construção, montagem de seus produtos, bem como por informações insuficientes ou inadequadas sobre a sua utilização e riscos é do construtor da edificação. Em contrapartida, o uso inadequado assim como a falta de manutenção determinada na concepção da edificação de acordo com as normas pertinentes, isenta as responsabilidades do construtor quanto aos procedimentos assistenciais. 
Gráfico 13: Desempenho da edificação ao longo do tempo - tempo de manutenção.

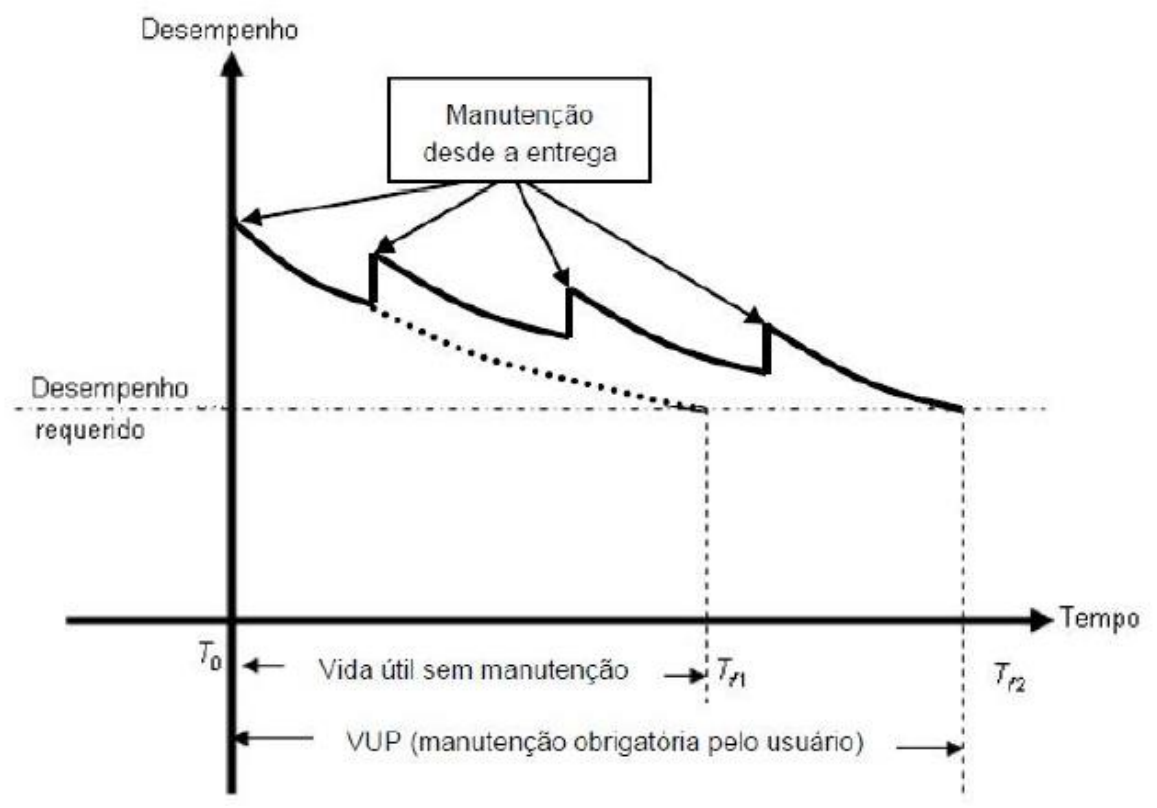

Fonte: NBR 15575 (2013)

Considerando o baixo nível de investimento em infraestrutura no país, a norma também estabelece a vida útil de cada sistema nela especificado (Tabela 15) visando orientar a formulação de manuais de manutenção e responsabilidade para os construtores.

Tabela 15: Vida Útil Mínima dos sistemas, conforme NBR 15575 (2013)

\begin{tabular}{|c|c|}
\hline Sistema & VUP minima em anos \\
\hline Estrutura & $\begin{aligned} & \geq 50 \\
& \text { segundo ABNT NBR } 8681-2003\end{aligned}$ \\
\hline Pisos internos & $\geq 13$ \\
\hline Vedação vertical externa & $\geq 40$ \\
\hline Vedação vertical interna & $\geq 20$ \\
\hline Cobertura & $\geq 20$ \\
\hline Hidrossanitário & $\geq 20$ \\
\hline \multicolumn{2}{|c|}{$\begin{array}{l}\text { * Considerando periodicidade e processos de manutenção especificados no respectivo Manual de } \\
\text { Uso, Operação e Manutenção entregue ao usuário elaborado em atendimento à ABNT NBR } 5674 \text {. }\end{array}$} \\
\hline
\end{tabular}

Fonte: NBR 15575 (2013)

Como proposta, a NBR 5674 (ABNT,1999) declara que a organização do sistema de manutenção deve levar em consideração as características de cada edificação. Diante disso, há a necessidade de o plano a ser aplicado ser específico. Esse é um dos principais objetivos desse trabalho: propor um modelo de plano de manutenção preventiva para uma determinada tipologia de edificação, as edificações de saúde em especial, os três Hemocentros específicos.

$\mathrm{Na}$ literatura, a respeito do tema manutenção de edificações por tipologias, temos poucos exemplos. A intenção é que as tipologias de edificações tenham normas específicas para o clima em que se inserem, e tipologias de projetos buscando melhor 
adequação e acerto em relação às fases de projetação e de manutenção, visando melhor desempenho e maior vida útil.

Segundo Araujo (2013), apesar de o país contar com um considerável número de arquitetos e engenheiros que realizam projetos de estabelecimentos de saúde, acumulando extensa experiência na área, seu número é ainda reduzido frente à atual demanda. A capacitação de profissionais como os técnicos das diversas áreas de saúde, o pessoal de manutenção de EAS, os funcionários dos serviços terceirizados dos EAS, que conheçam e atendam às necessidades do usuário e às modernas técnicas assistenciais e construtivas, garantem as boas condições de funcionalidade, salubridade e conforto no estabelecimento de saúde, além de maximizar a eficiência da aplicação dos recursos financeiros às edificações e adequar os projetos à realidade sanitária do país e à saúde pública.

As edificações de saúde possuem dois componentes indispensáveis e complementares: o componente de procedimentos, em relação às pessoas, utensílios, roupas e resíduos e o componente arquitetônico, referente a uma série de elementos construtivos, como: resíduos e equipamentos, resíduos sólidos, sistemas de renovação e controle de correntes de ar, facilidades de limpeza das superfícies e materiais e instalações para a implementação do controle de infecções.

Os itens analisados por Araujo (2013) são: manutenção de sistema de ar condicionado, resíduos de produtos químicos oriundos de processadoras, reuso de água em EAS, visando a criação de um manual. Nesse documento, é estabelecido para os sistemas de ar condicionado, por exemplo, os requisitos técnicos do sistema que são os filtros de ar, os condicionadores de ar, os gabinetes, os ventiladores, os resfriadores e aquecedores, os umidificadores, os sistemas de recuperação de calor, as salas de máquinas, as tomadas e descargas de ar e os dutos de ar. Também contém diretrizes que para a implementação de medidas que protejam a segurança e a saúde dos trabalhadores, pois a falta de desse tipo de práticas podem interferir na saúde do usuário, que, em muitas situações, encontra-se com saúde debilitada.

De acordo com Araujo (2013), após selecionar o EAS, o funcionário responsável pela manutenção deste item deve seguir os seguintes passos:

- Levantar todos os dados da Central de Ar Condicionado, o tipo de sistema utilizado, o número de máquinas instaladas, o local da central e das máquinas, as unidades hospitalares que cada máquina atende, o projeto de arquitetura e o projeto de ar condicionado;

- Verificar/elaborar o projeto de ar condicionado incluindo planta baixa, planta de teto, detalhes de execução e ver se há comando independente nas salas e/ou unidades atendidas; 
- Verificar e atentar para o local de instalação das máquinas fan-coil;

- Selecionar os aparelho-termômetros para fazer as medições;

- Fazer as medições das temperaturas do ar e umidade relativa do ar trimestrais, utilizando as fichas/tabelas modelo;

- As medições serão feitas nas máquinas fan-coil, que atendem aos ambientes climatizados, em vários períodos do ano, como verão, inverno, primavera e outono em três locais: na serpentina, na entrada da água e na saída do duto de distribuição. E nos ambientes, na saída do difusor e na altura de uma pessoa, considerada como temperatura ambiente:

- As medições serão indicadas com as tabelas e gráficos encontrados;

- Comparar as temperaturas e umidade padrão das maquinas e dos ambientes;

- A medição padrão de temperatura de água nos compressores é de $5^{\circ} \mathrm{C}$ na central de ar condicionado e no condensador é de $33^{\circ} \mathrm{C}$; a temperatura normal na serpentina é de $14^{\circ} \mathrm{C}$. a temperatura de conforto do local pode variar de $22^{\circ} \mathrm{C}$ a $24^{\circ} \mathrm{C}$, podendo variar $1,5^{\circ} \mathrm{C}$ para cima ou para baixo; a umidade relativa do ar é de $50 \%$, podendo variar para $5 \%$ para cima ou para baixo;

- Verificar e anotar as irregularidades do sistema;

- Levantar os tipos de filtros instalados e adequá-los aos padrões referidos;

- Limpar os filtros quinzenalmente;

- Substituir os filtros de 3 a 4 meses;

- Utilizar filtros de classe adequada para cada unidade;

- Fazer limpeza semestral na rede de dutos (manual ou robotizada);

- Fazer análise em laboratório especializado da qualidade do ar e do sistema encontrados, após a limpeza;

- Fazer relatório semanal de todo o sistema em ficha padrão;

- Adequar todo o sistema climatizado às normas pertinentes;

- Contratar firma especializada para realizar a manutenção do sistema, acompanhar, avaliar e adequar;

- Colocar todo o sistema em automação para controlar a temperatura do ar e a umidade relativa do ar;

- Utilizar materiais de acabamento adequados aos ambientes climatizados (BRASIL, 2002); 
- Utilizar material de isolamento térmico e acústico nos ambientes das maquinas nas centrais, nas redes de dutos, nos locais dos compressores e torres de arrefecimento;

- Fazer campanha permanente do sistema para informar ao usuário a importância de um sistema eficiente para a saúde e para o meio ambiente;

- Usar a APO no usuário/funcionário/paciente (doador, no caso do Hemocentro), aplicando questionários ou fazendo entrevistas, em relação ao sistema: temperatura e umidade relativa do ar, conforto térmico, ambiente de trabalho;

- Envolver os profissionais do sistema com a administração, com a arquitetura e com a engenharia dos EAS;

- Propor procedimentos.

No manual ainda inclui um tópico com material de acabamento, acessórios, descrições e explicações pertinentes a esse sistema. A proposta de tabelas e formulários para auxiliar na manutenção são de fácil preenchimento, controle e podem ser graficamente tabuladas (Anexo 1).

Na segunda parte Araujo (2013), explicita sobre uma questão bastante delicada nas EASs, que são os Resíduos dos Produtos Químicos Oriundos das Processadoras, pois os órgãos de controle ambiental passaram a exigir tratamento diferenciado para os Resíduos dos Serviços de Saúde (RSS) sobre o meio ambiente e orientam a elaboração de projetos específicos para as EASs. As instruções contidas no manual contribuem para o gerenciamento dos resíduos, para o meio ambiente e para a saúde da população, conforme os seguintes passos:

- Selecionar o EAS;

- Elaborar um programa de trabalho para aplicar o PGRSS, utilizando as normas pertinentes;

- Levantar e analisar o procedimento diário de coleta e transporte;

- Contratar firma especializada para realizar a manutenção do sistema, acompanhar, avaliar e adequar;

- Levantar e analisar o procedimento dos rejeitos das processadoras de Raio X;

- Programar dia e horário de coleta do revelador e fixador;

- Fazer relatório semanal de todo o sistema em ficha padrão;

- Fazer análise em laboratório especializado de resíduos; 
- Verificar a análise química laboratorial e adequá-la às normas pertinentes;

- Adequar o sistema ao descarte no meio ambiente;

- Adequar a central de lixo às normas;

- Fazer campanha permanente do sistema para informar ao usuário a importância de um sistema eficiente para a saúde e para o meio ambiente; envolver os profissionais do sistema com a administração do EAS, com a arquitetura e com a engenharia do EAS;

- Propor procedimentos.

No caso dos Hemocentros, a maior quantidade de resíduos é gerada por objetos e materiais utilizados na coleta e análise do sangue, com grande parte de produtos perfurantes e contaminantes. A autora indica a elaboração e aplicação de um check list específico para esse sistema (Tabela 17), em que são indicados o local a ter o resíduo retirado, o tipo de resíduo sólido gerado, dividido em grupos ( $A, B, C, D$ e $E)$.

Tabela 16: Indicação do local e resíduos sólidos gerados, divididos em grupos.

\begin{tabular}{|c|l|c|}
\hline LOCAL & RESÍDUOS SÓLIDOS GERADOS & $\begin{array}{c}\text { EFLUENTES } \\
\text { LÍQUIDOS }\end{array}$ \\
\hline $\begin{array}{c}\text { Térreo - } \\
\text { Radiologia }\end{array}$ & $\begin{array}{c}\text { Sila de Espera e } \\
\text { Circulação }\end{array}$ & $\begin{array}{l}\text { Grupo B - lâmpadas } \\
\text { Grupo D - varredura }\end{array}$ \\
\hline Câmara Escura & $\begin{array}{l}\text { Grupo B - lâmpadas } \\
\text { Grupo D - varredura, filme }\end{array}$ & $\begin{array}{l}\text { NAluente de tanque, ralo, e } \\
\text { da máquina de reciclagem } \\
\text { de produtos químicos } \\
\text { radiográficos. }\end{array}$ \\
\hline Sala de Exames & $\begin{array}{l}\text { Grupo A - luva, gases, embalagens } \\
\text { contaminadas, sacos plástico contaminados, } \\
\text { algodão, fraldas } \\
\text { Grupo B - lâmpada } \\
\text { Grupo D - varredura }\end{array}$ & \multicolumn{1}{c|}{ NA } \\
\hline Câmara Clara & $\begin{array}{l}\text { Grupo B - lâmpada, revelador e fixador } \\
\text { Grupo D - varredura, papel, plástico, } \\
\text { lata, embalagem de filme, papelão, copos } \\
\text { descartáveis, }\end{array}$ & $\begin{array}{l}\text { Efluente de pia, ralo com } \\
\text { águas de lavagem com } \\
\text { sabão, cloro, detergente }\end{array}$ \\
\hline
\end{tabular}

Fonte: Araujo, 2013.

Araujo (2013) sugere também a elaboração de uma tabela que responda questionamentos básicos sobre os resíduos, sendo eles: onde está localizada a área de abrangência, o tipo de risco que a atividade gera, quem está exposto ao risco, a forma de exposição, maior probabilidade de ocorrência de contaminação e a forma de controle do risco (Tabela 18). 
Tabela 17: Tabela proposta por Araujo (2013) para gerenciamento de resíduos em EAS.

\begin{tabular}{|c|c|c|c|c|c|}
\hline ONDE & OQUE & QUEM & COMO & QUANDO & AÇÃO \\
\hline $\begin{array}{l}\text { Área de } \\
\text { abrangência }\end{array}$ & $\begin{array}{l}\text { Descrever o } \\
\text { tipo de risco } \\
\text { e a atividade } \\
\text { que gera o } \\
\text { risco }\end{array}$ & $\begin{array}{l}\text { Quem está } \\
\text { exposto ao risco } \\
\text { identificado }\end{array}$ & $\begin{array}{l}\text { Descrever } \\
\text { a forma de } \\
\text { exposição }\end{array}$ & $\begin{array}{l}\text { Descrever } \\
\text { momentos ou } \\
\text { fases da jornada } \\
\text { de trabalho onde } \\
\text { a probabilidade de } \\
\text { ocorrência é maior }\end{array}$ & $\begin{array}{l}\text { Descrever forma } \\
\text { de controle do } \\
\text { risco }\end{array}$ \\
\hline $\begin{array}{l}\text { Setor de } \\
\text { Radiologia }\end{array}$ & $\begin{array}{l}\text { Riscos } \\
\text { Biológicos: } \\
\text { contaminação } \\
\text { por agentes } \\
\text { infecciosos } \\
\\
\text { Químicos: } \\
\text { contaminação } \\
\text { por produtos } \\
\text { químicos }\end{array}$ & $\begin{array}{l}\text { Pesquisadores, } \\
\text { Técnicos } \\
\text { Pessoal da } \\
\text { limpeza }\end{array}$ & $\begin{array}{l}\text { Lesão por } \\
\text { corte causada } \\
\text { por residuos } \\
\text { perfurocortantes }\end{array}$ & $\begin{array}{l}\text { Momento do } \\
\text { acondicionamento } \\
\text { Pessoal da limpeza } \\
\text { Horário da coleta } \\
\text { interna } 7 \text { às 9:00 h. } \\
\text { Momento da } \\
\text { manipulação ou } \\
\text { na execução das } \\
\text { tarefas }\end{array}$ & $\begin{array}{l}\text { - Segregação } \\
\text { correta; } \\
\text { acondicionamento } \\
\text { adequado, } \\
\text {-Uso de EPI } \\
\text {-Vacinação de } \\
\text { todos os servidores } \\
\text {-Adquirir latas de } \\
\text { lixo com tampa, } \\
\text { pedal e conforme } \\
\text { Normas } \\
\text { - Treinar } \\
\text { funcionários para o } \\
\text { descarte adequado } \\
\text { de resíduos. }\end{array}$ \\
\hline
\end{tabular}

Fonte: Araujo, 2013.

Outra sugestão da autora é a divisão dos resíduos por grupos, em que possa ser indicada a situação de cada resíduo e qual o procedimento de tratamento de cada grupo (Tabela 19).

Tabela 18: Destinação e tratamento dos resíduos conforme grupos.

\begin{tabular}{|c|l|l|}
\hline $\begin{array}{c}\text { SITUAÇÃO DOS } \\
\text { PRINCÍPIOS DO SISTEMA }\end{array}$ & \multicolumn{1}{|c|}{ SITUAÇÃo } & \multicolumn{1}{c|}{ PROCEDIMENTOS } \\
\hline Grupo A & $\begin{array}{l}\text { Encaminhados para o Aterro de } \\
\text { Gramacho (RJ) }\end{array}$ & $\begin{array}{l}\text { Cobertura diária em célula } \\
\text { especial }\end{array}$ \\
\hline Grupo B & $\begin{array}{l}\text { Coletados de } 20 \mathrm{em} 20 \text { dias e } \\
\text { encaminhados para a firma X } \\
\text { que trata o fixador e encaminha } \\
\text { o revelador para a firma Y }\end{array}$ & $\begin{array}{l}\text { Incinerados o resíduo líquido } \\
\text { revelador e para a rede pública de } \\
\text { esgoto o tratamento do fixador }\end{array}$ \\
$\begin{array}{l}\text { Aterro industrial para os resíduos } \\
\text { sólidos }\end{array}$ \\
\hline
\end{tabular}

Fonte: Araujo, 2013.

Outro ponto destacado pela autora é a elaboração de uma tabela que identifique o risco associado ao equipamento, ao local onde está implantado e esse equipamento e o custo para gerenciamento desse resíduo (Tabela 20). 
Tabela 19: Proposta de tabela para avaliação entre risco e custo no gerenciamento do resíduo.

\begin{tabular}{|c|c|c|c|}
\hline $\begin{array}{c}\text { RISCO } \\
\text { ASSOCIADO }\end{array}$ & EQUIPAMENTO & LOCAL & CUSTO \\
\hline $\begin{array}{c}\text { Contaminação por } \\
\text { material biológico, } \\
\text { material químico }\end{array}$ & $\begin{array}{c}\text { Contêineres, sistema de } \\
\text { tratamento } \\
\text { Luvas, botas, veículos } \\
\text { apropriados para } \\
\text { transporte interno }\end{array}$ & $\begin{array}{c}\text { Salas dos médicos, de } \\
\text { exames, preparo de } \\
\text { paciente, } \\
\text { Salas de interpretação } \\
\text { radiológica, câmara } \\
\text { escura, clara, preparo de } \\
\text { contrastes }\end{array}$ & $\mathrm{X}$ \\
\hline $\begin{array}{c}\text { Contaminação do meio } \\
\text { ambiente }\end{array}$ & $\begin{array}{c}\text { Veículo adequado p/ } \\
\text { transporte externo e } \\
\text { interno }\end{array}$ & Transporte de resíduos & $\mathrm{Y}$ \\
\hline
\end{tabular}

Fonte: Araujo, 2013.

A terceira e última parte do trabalho elaborado por Araujo (2013), discorre sobre o aproveitamento das águas previamente utilizadas, buscando suprir as necessidades de outros usos benéficos. As diretrizes da autora são as seguintes:

- Selecionar o EAS;

- Elaborar um Programa de Gerenciamento de Resíduos dos Serviços de Saúde (PGRSS);

- Envolver grupo de trabalho para aplicar o PGRSS, utilizando as normas pertinentes;

- Levantar e analisar o procedimento diário de coleta e transporte;

- Contratar firma especializada para realizar a manutenção do sistema, acompanhar, avaliar e adequar;

- Levantar e analisar o procedimento dos rejeitos das processadoras de Raio X;

- Programar dia e horário de coleta do revelador e do fixador;

- Fazer relatório semanal de todo o sistema em ficha padrão;

- Fazer análise em laboratório especializado de resíduos;

- Verificar a análise química laboratorial e adequá-la às normas pertinentes;

- Adequar o sistema ao descarte no meio ambiente;

- Adequar a central de lixo às normas;

- Fazer campanha permanente do sistema para informar ao usuário a importância de um sistema eficiente para a saúde e para o meio ambiente;

- Envolver os profissionais do sistema com a administração do EAS, com a arquitetura e com a engenharia do EAS;

- Propor procedimentos. 
Infelizmente não há na literatura dados de água de reuso consumida para edificações de saúde. O plano de reuso de agua proposto para EASs é uma iniciativa pioneira para essa tipologia de edificação e visa somente atender a fins menos nobres, de qualidade não potável como descarga de vaso sanitário, lavagem de pisos, calçadas, ruas e automóveis, irrigação de canteiros e jardins, irrigação agrícola em geral, construção civil para cura do concreto, sistema e reserva contra incêndio, fluído auxiliar de resfriamento no sistema de ar condicionado.

A água para reuso pode ser dividida em classes 1, 2, 3 e 4, sendo que para adaptações em EASs, indicam-se somente as classes 1, 2 e 3 (Tabela 21).

Tabela 20: Tabela de classificação de água de reuso

\begin{tabular}{|c|c|c|c|c|}
\hline & Destinação & $\begin{array}{l}\text { PARÃMETROS } \\
\text { CONTEMPLADOS }\end{array}$ & TraTAMENTO INDICADO & OBSERVAÇOES \\
\hline $\begin{array}{c}\text { Classe } \\
1\end{array}$ & $\begin{array}{l}\text { lavagem } \\
\text { de carros e } \\
\text { outros usos } \\
\text { que requerem } \\
\text { o contato } \\
\text { direto do } \\
\text { usuário com } \\
\text { a água }\end{array}$ & $\begin{array}{c}\text { CF }<200 \mathrm{nmp} / 100 \mathrm{ml} \\
- \text { sólidos dissolvidos } \\
\text { totais }<200 \mathrm{mg} / 1 \\
-\mathrm{H} \text { de } 6-8 \\
-\mathrm{Cl} 0,5-1,5 \mathrm{mg} / 1 \\
\text {-turbidez }<5\end{array}$ & $\begin{array}{l}\text { tratamento aeróbio + } \\
\text { filtração convencional } \\
\text { com areia e carvão } \\
\text { ativado + cloração }\end{array}$ & $\begin{array}{l}\text { pode-se substituir a filtração } \\
\text { convencional por membrana } \\
\text { filtrante }\end{array}$ \\
\hline $\begin{array}{c}\text { Classe } \\
2\end{array}$ & $\begin{array}{l}\text { lavagem de } \\
\text { pisos calçadas } \\
\text { e irrigação } \\
\text { de jardins, } \\
\text { manutenção } \\
\text { de canais } \\
\text { e lagos } \\
\text { para fins } \\
\text { paisagísticos }\end{array}$ & $\begin{array}{c}-\mathrm{CF}, 500 \mathrm{nmp} / 100 \mathrm{ml} \\
\text {-turbidez }<5 \\
-\mathrm{Cl}>0,5 \mathrm{mg} / 1\end{array}$ & $\begin{array}{l}\text { tratamento aeróbio } \\
+ \text { filtro de areia e } \\
\text { desinfecção }\end{array}$ & $\begin{array}{l}\text { pode-se substituir a filtração } \\
\text { convencional por membrana } \\
\text { filtrante }\end{array}$ \\
\hline
\end{tabular}

\begin{tabular}{|c|l|c|c|c|}
\hline $\begin{array}{c}\text { Classe } \\
3\end{array}$ & $\begin{array}{l}\text { descargas } \\
\text { dos vasos } \\
\text { sanitários }\end{array}$ & $\begin{array}{c}-\mathrm{CF}<500 \mathrm{nmp} / 100 \mathrm{ml} \\
\text { tratamento aeróbio + } \\
\text { cloração }\end{array}$ & $\begin{array}{c}\text { as águas provenientes } \\
\text { de máquinas de lavar } \\
\text { satisfazem a este padrão }\end{array}$ \\
\hline $\begin{array}{c}\text { Classe } \\
4\end{array}$ & $\begin{array}{l}\text { reúso nos } \\
\text { pomares, } \\
\text { pastagens } \\
\text { para gado }\end{array}$ & $\begin{array}{c}\text { CF }<5.000 \mathrm{nmp} / 100 \mathrm{ml} \\
\text { OD }>2,0 \mathrm{mg} / 1\end{array}$ & escoamento superficial & $\begin{array}{c}\text { terrompidas pelo menos 10 } \\
\text { dias antes da colheita }\end{array}$ \\
\hline
\end{tabular}

Fonte: Araujo, 2013.

As Estações de Tratamento de Esgoto (ETEs) podem ser locadas na superfície ou no subterrâneo pois o mau cheiro não é algo percebível pelo usuário. Por meio da NRB 15575, inicia-se um processo de implementação de manuais de manutenção que passam a 
ter um caráter mais elaborado e formal com profissionais habilitados. Mas como pode-se perceber a indicação ainda é somente para edifícios residenciais não contemplando EAS. Entretanto, com o trabalho realizado por Araujo (2013), foi possível perceber a inexistência de normas específicas de manutenção para edificações não residenciais e, sobretudo, a importância deste tipo de estudo que pode orientar normativas ainda inexistentes por tipologias. 


\section{CONTEXTUALIZAÇÃO DAS EDIFICAÇÕES}

Para o desenvolvimento da pesquisa, tem-se a leitura dos referenciais teóricos e conceituais para estabelecer os critérios de análise crítica das AAls dos três Hemocentros em estudo. A partir das questões expostas anteriormente, têm-se parâmetros para elaboração das diretrizes de desempenho ambiental e proposição de normativas a partir das pesquisas de certificação e etiquetagem de edifícios em andamento. A partir do referencial conceitual exposto, são apresentados quadros comparativos entre as três edificações a fim de gerar um conjunto de informações sobre o tema e tipologia arquitetônica.

Nas AAls, inicialmente, é apresentada a contextualização da edificação a ser estudada, local, área, particularidades, situação do projeto e situação das plantas em geral (Quadro 4).

Quadro 4: Características gerais das edificações em estudo.

\begin{tabular}{|c|c|c|c|}
\hline HEMOCENTRO & ÁREAS & $\begin{array}{l}\text { PARTICULARIDADES e } \\
\text { CARACTERÍSTICAS }\end{array}$ & SITUAÇÃO DAS PLANTAS \\
\hline HEMOAM & Área total de $8.000,00 \mathrm{~m} 2$ & $\begin{array}{l}\text { Composto por cinco } \\
\text { volumes interligados, } \\
\text { facilidade de acesso }\end{array}$ & $\begin{array}{l}\text { necessário que fosse feito } \\
\text { levantamento in loco, informações } \\
\text { desatualizadas e inexistentes }\end{array}$ \\
\hline HEMODF & $\begin{array}{l}\text { Área total de } 4.674,20 \mathrm{~m} 2 \\
\text { Bloco } A-A=1.658,15 \mathrm{~m} 2 \text { e } \\
\text { Bloco } B-A=2.654,44 \mathrm{~m} 2\end{array}$ & $\begin{array}{l}\text { Bloco A é o mais antigo } \\
\text { contempla a parte } \\
\text { relacionada à saúde, } \\
\text { abrigando desde a parte } \\
\text { das doações até os } \\
\text { laboratórios. Bloco B, mais } \\
\text { recente, concentra a parte } \\
\text { administrativa, cafeteria, } \\
\text { biblioteca e área de } \\
\text { convívio }\end{array}$ & $\begin{array}{l}\text { as plantas fornecidas pelo } \\
\text { Arquiteto Luis Otávio Alves } \\
\text { Rodrigues, autor de uma das } \\
\text { reformas em 2000, foram } \\
\text { atualizadas. }\end{array}$ \\
\hline HEMORGS & $\begin{array}{l}\text { Dado não fornecido pela } \\
\text { Avaliação. }\end{array}$ & $\begin{array}{l}\text { Edifícios de uma } \\
\text { pavimento formam o } \\
\text { complexo do Hemocentro, } \\
\text { que logo receberá um nova } \\
\text { sede, no terreno ao lado }\end{array}$ & $\begin{array}{l}\text { levantamento in loco, } \\
\text { desatualização de informações ou } \\
\text { inexistentes nas plantas } \\
\text { fornecidas inicialmente }\end{array}$ \\
\hline
\end{tabular}

Fonte: Elaborado pela autora, 2016.

O Hemocentro de Porto Alegre possui dois blocos. No entanto, a AAI realizada no local foi realizada em busca da reabilitação desses dois blocos e implantação de três novos blocos.

Podemos notar uma falta de acompanhamento da realidade arquitetônica com a documentação de projetos em todas as unidades. As reformas e adequações não foram atualizadas no projeto o que demandou maior tempo da equipe que necessitou realizar medições in loco e adequações projetuais. 
Para que se possa traçar uma característica mais precisa da avaliação, foi necessário analisar o plano diretor das três edificações para conferir se a edificação está em local adequado; se há previsão de desenvolvimento de edificações futuras no local ou até mesmo de acréscimos e o impacto dessas novas edificações nas existentes.

O quadro 5 apresenta as características urbanísticas das edificações com as simulações computacionais adotadas e as inadequações do ponto de vista conforto e do bioclimatismo. No Pelas APOs, a equipe pôde elaborar diretrizes para atender os diferentes usuários dessa edificação, divididas em quatro: melhorias na qualidade térmica, luminosa, sonora e ambiental (Quadro 6).

O quadro 7, tem-se as diretrizes propostas na APO, em que foi possível elaborar diretrizes projetuais para a reabilitação ambiental das três unidades. Os quadros 9 e 10 apresentam as recomendações para as três unidades a partir da AAls. 
Quadro 4: Características urbanísticas, simulações e inadequações das edificações

\begin{tabular}{|c|c|c|c|}
\hline HEMOCENTRO & $\begin{array}{l}\text { REGULAMENTOS URBANÍSTICOS DO } \\
\text { LOCAL }\end{array}$ & SIMULADORES COMPUTACIONAIS & INADEQUAÇÕES \\
\hline HEMOAM & $\begin{array}{l}\text { para esta zona, o Plano Diretor amplia os } \\
\text { níveis de adensamento construtivo, } \\
\text { condicionadas à possibilidade de infra estrutura } \\
\text { e serviços e à sustentabilidade urbanística }\end{array}$ & $\begin{array}{l}\text { ENVI-met 3.1, Ecotect Analysis } 2011 \text { e } \\
\text { ANSYS }\end{array}$ & $\begin{array}{l}\text { elevada carga térmica em algumas orientações, pela } \\
\text { excessiva exposição à radiação solar; deficiência da luz } \\
\text { natural, abaixo do recomendado para as atividades } \\
\text { desenvolvidas e ambientes expostos a excessivos ruídos } \\
\text { externos devido ao isolamento insuficiente e } \\
\text { equipamentos defasados }\end{array}$ \\
\hline HEMODF & $\begin{array}{l}\text { o edifício está inserido em uma zona urbana } \\
\text { não consolidada, foi necessário realizar uma } \\
\text { simulação computacional para verificar quais } \\
\text { serão as divergências climáticas (temperatura, } \\
\text { umidade e ventilação) que um futuro edifício, } \\
\text { situado a leste do hemocentro, causará no seu } \\
\text { espaço urbano. }\end{array}$ & $\begin{array}{l}\text { ENVI-met 3.1, RELUX, DAYSIM/RADIANCE, } \\
\text { Ecotect Analysis e REVERB }\end{array}$ & $\begin{array}{l}\text { elevada carga térmica em algumas orientações, pela } \\
\text { excessiva exposição à radiação solar; deficiência da luz } \\
\text { natural, abaixo do recomendado para as atividades } \\
\text { desenvolvidas e ambientes expostos a excessivos ruídos } \\
\text { externos e internos devido ao isolamento insuficiente e } \\
\text { equipamentos defasados, e má distribuição em relação a } \\
\text { divisão usuário por ambiente. }\end{array}$ \\
\hline HEMORGS & $\begin{array}{l}\text { O Plano Diretor de Desenvolvimento Urbano } \\
\text { Ambiental incorpora o enfoque ambiental de } \\
\text { planejamento na definição do modelo de } \\
\text { desenvolvimento do Município, das diretrizes e } \\
\text { das estratégias para a execução de planos, } \\
\text { programas e projetos, enfatizando a } \\
\text { participação popular, a sustentabilidade } \\
\text { econômica, social e ambiental (Lei 434/1999) }\end{array}$ & Ecotect Analysis, RELUX & $\begin{array}{l}\text { elevada carga térmica em algumas orientações, pela } \\
\text { excessiva exposição à radiação solar; deficiência da luz } \\
\text { natural, abaixo do recomendado para as atividades } \\
\text { desenvolvidas e ambientes expostos a excessivos ruídos } \\
\text { externos devido ao isolamento insuficiente e } \\
\text { equipamentos defasados. } \\
\text { a área no qual o hemocentro se encontra é insuficiente } \\
\text { para cumprir todas as funções da edificação, sendo assim } \\
\text { nova área ao lado também fará parte do complexo, } \\
\text { completando as metragens, setorizações e ambientes } \\
\text { ainda inexistentes nesta edificação. }\end{array}$ \\
\hline
\end{tabular}

Fonte: Elaborado pela autora, 2016. Adaptado LASUS $(2011,2012,2015)$.. 
Quadro 5: Quadro de Diretrizes da APO

\section{DIRETRIZES DA APO}

\begin{tabular}{|c|c|c|c|c|}
\hline HEMOCENTRO & TÉRMICO & LUMINOSO & SONORO & AMBIENTAL \\
\hline MANAUS & $\begin{array}{l}\text { Reduzir ganhos de carga } \\
\text { térmica pelas fachadas, com } \\
\text { proteções solares adequadas; } \\
\text { reduzir os ganhos de carga } \\
\text { térmica através da cobertura; } \\
\text { promover o resfriamento } \\
\text { evaporativo; buscar sempre o } \\
\text { aproveitamento da ventilação } \\
\text { natural; buscar uniformidade } \\
\text { de temperatura e umidade nos } \\
\text { ambientes condicionados } \\
\text { artificialmente }\end{array}$ & $\begin{array}{l}\text { Melhorar a uniformidade da iluminação } \\
\text { artificial, melhorar distribuição de luminárias, } \\
\text { utilizar vidros seletivos, buscar a iluminação } \\
\text { no plano de trabalho otimizando a qualidade } \\
\text { da luz; otimizar a qualidade da luz e a } \\
\text { eficiência energética; estudar integração com } \\
\text { a iluminação natural; garantir vista agradável } \\
\text { para o exterior; implantar sistema de } \\
\text { automação de luz }\end{array}$ & $\begin{array}{l}\text { Reduzir os níveis de ruído; } \\
\text { tratar acusticamente os } \\
\text { ambientes onde existe a } \\
\text { interferência de ruídos } \\
\text { indesejados; reduzir os níveis } \\
\text { de ruídos dos equipamentos } \\
\text { externos, aumentar o fator de } \\
\text { rugosidade do meio externo, a } \\
\text { fim de recolher ruídos } \\
\text { indesejáveis }\end{array}$ & $\begin{array}{l}\text { Integrar o hemocentro aos hospitais } \\
\text { vizinhos; criar ambientes de convivência; } \\
\text { reabilitar espaços insalubres; implantar } \\
\text { vegetação como elemento de } \\
\text { requalificação ambiental e humanização; } \\
\text { implantar microbacias de contenção de } \\
\text { água das chuvas promovendo maior } \\
\text { eficiência à drenagem natural; tornar } \\
\text { espaços acessíveis; tratar espaços } \\
\text { internos e externos do edifício visando à } \\
\text { humanização e otimização das atividades; } \\
\text { garantir ambiência harmônica eliminando } \\
\text { barreiras na forma de muros. }\end{array}$ \\
\hline DF & $\begin{array}{l}\text { Redução do ganho de carga } \\
\text { térmica pelas fachadas, com } \\
\text { proteções solares adequadas, } \\
\text { por meio da redução da área } \\
\text { de vidro e especificação do } \\
\text { fator solar e através da } \\
\text { cobertura; aproveitamento da } \\
\text { ventilação natural como } \\
\text { estratégia de otimização do } \\
\text { conforto; forros claros e } \\
\text { ventilados }\end{array}$ & $\begin{array}{l}\text { Aumento do aproveitamento da iluminação } \\
\text { natural; aumento na uniformidade de } \\
\text { distribuição dos níveis de iluminância; uso de } \\
\text { prateleiras de luz; vidros seletivos; iluminação } \\
\text { no plano de trabalho; estudo de integração } \\
\text { com iluminação artificial; garantia de vista } \\
\text { agradável para o exterior }\end{array}$ & $\begin{array}{l}\text { Redução dos níveis de ruído } \\
\text { em ambientes críticos; redução } \\
\text { da propagação do ruído } \\
\text { externo; redução dos níveis de } \\
\text { ruídos dos equipamentos } \\
\text { externos }\end{array}$ & $\begin{array}{l}\text { Restringir ganhos solares, promover } \\
\text { resfriamento evaporativo, altera materiais } \\
\text { superficiais em vista a qualidade } \\
\text { ambiental; criação de ambientes de } \\
\text { convivência; implantação de vegetação } \\
\text { nativa do cerrado; captação e reuso de } \\
\text { águas pluviais; equipamentos e mobiliário } \\
\text { urbano; condução de brisa resfriada para } \\
\text { o interior da edificação; acessibilidade }\end{array}$ \\
\hline
\end{tabular}

Fonte: Elaborado pela autora, 2016. Adaptado LASUS $(2011,2012,2015)$. 
Quadro 7: Quadro de Diretrizes para Reabilitação

\begin{tabular}{|c|c|}
\hline HEMOCENTRO & DIRETRIZES PARA A REABILITAÇÃO \\
\hline MANAUS & $\begin{array}{l}\text { Inserção urbana com praças, estar, feira; inserção social com acessos, elementos da cultura local, elementos de fachada, módulos sombreadores; } \\
\text { comunicação visual com passarela, painel em LED, elementos de fachada; gradil, controle de fluxos, guaritas; acessibilidade com passeios } \\
\text { cobertos, passarela, praças; priorização do Pedestre com áreas pavimentadas e passeios cobertos; humanização através de áreas verdes, cores, } \\
\text { módulos sombreadores; conforto ambiental através de pavimentação verde, parede verde, módulos sombreadores; implantação de placas } \\
\text { fotovoltaicas, biovaletas; revitalização das áreas verdes com talude, praças, parede verde; otimização dos Fluxos com passeios, passarela, } \\
\text { pavimentação, cores de fachada. }\end{array}$ \\
\hline DF & $\begin{array}{l}\text { criação com passeio e locais de permanência protegidos do sol e seguros; criação de rua de pedestres; uso de fachada verde; uso de piso } \\
\text { permeável; utilização de elementos ambientais(água, solo e vegetação); criação de quiosque de lazer para doador e funcionários; criação de } \\
\text { módulos de fachada que reduzam a incidência a carga térmica nas superfícies envidraçadas, o nível de iluminância, que distribua a luz natural no } \\
\text { interior dos ambientes, proporcione ventilação natural, e que solucione esteticamente o posicionamento das evaporadoras; implantação de } \\
\text { fachadas verdes compostas de espécies próprias do cerrado e expostas ao sol; implantação de cobertura verde e criação de ambiente de } \\
\text { recepção universal }\end{array}$ \\
\hline PORTO ALEGRE & $\begin{array}{l}\text { o novo Hemocentro contará com } 5 \text { blocos, sendo } 2 \text { antigos e } 3 \text { novos, interligados por passarelas cobertas que criam um parque urbano; espaço } \\
\text { convidativo; materiais que trabalham o sensorial-lúdico; nova planta baixa ( fluxos e distribuição dos ambientes); protetores solares mais eficientes; } \\
\text { acessibilidade universal; proteção externas (sol e chuva); passarelas com pisos drenantes; reaproveitamento de águas pluviais; implantação de } \\
\text { placas fotovoltáicas; verificar a possibidade de troca da cobertura por telha termo-acústica; troca de vidros e películas em busca do melhor } \\
\text { aproveitamento da luz natural; troca dos caixilhos para aproveitamento da ventilação natural; preservação das árvores existentes no local; } \\
\text { utilização de infraestrutura verde como biovaletas, jardins de chuvas, canteiros e lagoas pluviais, paredes verdes; implantação de espécies } \\
\text { vegetais adequadas ao clima local }\end{array}$ \\
\hline
\end{tabular}

Fonte: Elaborado pela autora, 2016. Adaptado LASUS $(2011,2012,2015)$.

O processo de etiquetagem energética da edificação permite avaliar seu nível de gasto energético e também localizar os maiores consumidores de energia da edificação, possibilitando nortear as recomendações para melhor desempenho energético separados por seus sistemas: iluminação, climatização, refrigeração, sistemas motrizes, perturbações elétricas e sistemas de bombeamento (Quadros 8 e 9). 
Quadro 8: Quadro de Recomendações 1

\begin{tabular}{|c|c|c|c|c|}
\hline \multicolumn{5}{|c|}{ RECOMENDAÇÕES } \\
\hline & $\begin{array}{l}\text { ETIQUE } \\
\text { TAGEM }\end{array}$ & RECOMENDAÇÕES PARA ILUMINAÇÃO & $\begin{array}{l}\text { RECOMENDAÇÕES } \\
\text { CLIMATIZAÇÃO }\end{array}$ & $\begin{array}{l}\text { RECOMENDAÇÕES SISTEMA } \\
\text { DE REFRIGERAÇÃO }\end{array}$ \\
\hline & 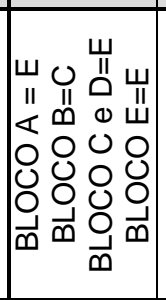 & & $\begin{array}{l}\text { Mudança da temperatura de controle } \\
\text { dos ambientes de } 23^{\circ} \mathrm{C} \text { para } 25^{\circ} \mathrm{C} \text {. } \\
\text { Aquisição de novos equipamentos } \\
\text { tipo split com selo A do PROCEL } \\
\text { EDIFICA }\end{array}$ & $\begin{array}{l}\text { Manutenção preventiva dos } \\
\text { sistemas e Retrofit das unidades } \\
\text { de resfriamento com vida útil } \\
\text { maior que } 20 \text { anos, sempre } \\
\text { visando a aquisição de } \\
\text { equipamentos com selo A do } \\
\text { PROCEL EDIFICA, quando } \\
\text { couber. }\end{array}$ \\
\hline 㟔 & 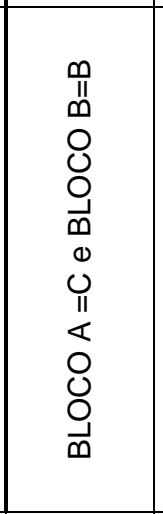 & $\begin{array}{l}\text { Prosseguir na substituição gradativamente o sistema de iluminação fluorescente } \\
\text { atual (40W) pelos sistemas que utilizam lâmpadas de } 32 \text { e } 28 \mathrm{~W} \text {;Segmentar os } \\
\text { circuitos em grupos menores de luminárias, principalmente em ambientes amplos, } \\
\text { dividindo-os por linhas de luminárias próximas e afastadas das janelas e de forma a } \\
\text { criar pequenos grupos independentes de trabalho; Segmentar o sistema elétrico das } \\
\text { luminárias próximas às janelas, permitindo que estas fiquem apagadas quando os } \\
\text { níveis de iluminância forem aceitáveis; Disponibilizar aos usuários acesso aos } \\
\text { interruptores a todas as salas que não o possuem ou sistemas de controle de } \\
\text { iluminação por meio de sensores de presença; Alterar o layout das estações de } \\
\text { trabalho de modo que as telas dos computadores fiquem sempre que possível em } \\
\text { posição lateral às janelas, evitando-se ofuscamentos nestas áreas de trabalho, } \\
\text { permitindo a utilização da iluminação natural; Adotar programas para } \\
\text { conscientização e educação dos funcionários sobre a importância de se conservar } \\
\text { energia e de que forma podem-se evitar desperdícios. }\end{array}$ & $\begin{array}{l}\text { Aquisição de novos equipamentos } \\
\text { com selo A do PROCEL EDIFICA. }\end{array}$ & $\begin{array}{l}\text { Retrofit progressivo das unidades } \\
\text { condensadoras }\end{array}$ \\
\hline 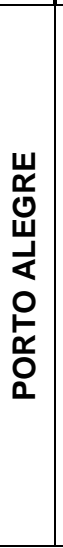 & 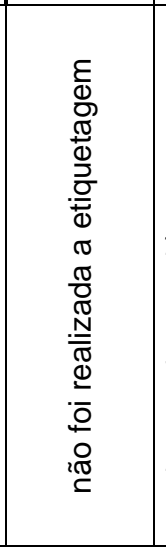 & $\begin{array}{l}\text { Retrofit dos sistemas de iluminação buscando maximizar o aproveitamento da } \\
\text { luminosidade emitida pelas lâmpadas; Segmentar os circuitos em grupos menores } \\
\text { de luminárias, principalmente em ambientes amplos, dividindo-os por linhas de } \\
\text { luminárias próximas e afastadas das janelas e de forma a criar pequenos grupos } \\
\text { independentes de trabalho; Segmentar o sistema elétrico das luminárias próximas às } \\
\text { janelas, permitindo que estas fiquem apagadas quando os níveis de iluminância } \\
\text { forem aceitáveis; Disponibilizar aos usuários acesso aos interruptores a todas as } \\
\text { salas que não o possuem ou sistemas de controle de iluminação por meio de } \\
\text { sensores de presença; Alterar o layout das estações de trabalho de modo que as } \\
\text { telas dos computadores fiquem sempre que possivel em posição lateral às janelas, } \\
\text { evitando-se ofuscamentos nestas áreas de trabalho, permitindo a utilização da } \\
\text { iluminação natural; Adotar programas para conscientização e educação dos } \\
\text { funcionários sobre a importância de se conservar energia e de que forma podem-se } \\
\text { evitar desperdícios. }\end{array}$ & $\begin{array}{l}\text { Avaliar a possibilidade de implantar } \\
\text { um sistema tipo self para todo o } \\
\text { edifício; Caso a implantação desse } \\
\text { sistema não se viabilize, promover a } \\
\text { substituição dos modelos tipo janela } \\
\text { por equipamentos tipo split com selo } \\
\text { A do PROCEL EDIFICA; Mantendo- } \\
\text { se a opção por sistemas tipo split, } \\
\text { realizar a aquisição de novos } \\
\text { equipamentos com selo A do } \\
\text { PROCEL EDIFICA; Realizar a } \\
\text { manutenção e limpeza dos filtros } \\
\text { periodicamente, evitando consumo } \\
\text { excessivo de energia e proliferação } \\
\text { de fungos e bactérias. }\end{array}$ & $\begin{array}{l}\text { Manutenção preventiva dos } \\
\text { sistemas e retrofit das unidades de } \\
\text { resfriamento com vida útil maior } \\
\text { que } 20 \text { anos }\end{array}$ \\
\hline
\end{tabular}

Fonte: Elaborado pela autora, 2016. Adaptado LASUS (2011, 2012, 2015). 
Quadro 9: Quadro de Recomendações 2

\begin{tabular}{|c|c|c|c|}
\hline \multicolumn{4}{|c|}{ RECOMENDAÇÕES } \\
\hline HEMOCENTRO & RECOMENDAÇÕES PARA OS SISTEMAS MOTRIZES & $\begin{array}{l}\text { RECOMENDAÇÕES PARA AS PERTURBAÇÕES } \\
\text { ELÉTRICAS }\end{array}$ & $\begin{array}{c}\text { RECOMENDAÇÕES PARA } \\
\text { SISTEMAS DE } \\
\text { BOMBEAMENTO }\end{array}$ \\
\hline MANAUS & $\begin{array}{l}\text { Substituição gradativa por motores de alto rendimento, } \\
\text { corretamente dimensionados,Aquisição de equipamentos } \\
\text { com motores de alto } \\
\text { rendimento. · Realização permanente de serviços de } \\
\text { manutenção. · Observação dos aspectos de qualidade de } \\
\text { energia e das } \\
\text { instalações elétricas para o bom funcionamento dos } \\
\text { motores. }\end{array}$ & $\begin{array}{l}\text { Atentar para os desequilíbrios de corrente nos painéis } \\
\text { elétricos do Hemocentro, procurando sempre manter as } \\
\text { correntes de fase equilibradas (melhor distribuição de } \\
\text { cargas).Utilização de equipamentos eletrônicos com fator de } \\
\text { potência dentro dos limites normalizados (> 0,92). Avaliação do } \\
\text { dimensionamento do banco de capacitores } \\
\text { existente no Hemocentro de Manaus. Realizar manutenção } \\
\text { adequada no banco de capacitores } \\
\text { existentes no Hemocentro de Manaus. }\end{array}$ & \\
\hline DF & $\begin{array}{l}\text { Substituição gradativa por motores de alto rendimento, } \\
\text { corretamente dimensionados; Aquisição de equipamentos } \\
\text { com motores de alto rendimento; Realização permanente de } \\
\text { serviços de manutenção; Observação dos aspectos de } \\
\text { qualidade de energia e das instalações elétricas para o bom } \\
\text { funcionamento dos motores. }\end{array}$ & & $\begin{array}{l}\text { Aquisição de conjunto moto- } \\
\text { bomba de alto rendimento. }\end{array}$ \\
\hline
\end{tabular}

Fonte: Elaborado pela autora, 2016. Adaptado LASUS $(2011,2012,2015)$. 
Um aspecto bastante citado nas três AAls foi o desconforto térmico dos usuários. Retomamos, nesse momento, a uma análise já apontada no trabalho: a inadequação dos partidos arquitetônicos e materiais utilizados no exercício de projetação dos arquitetos brasileiros.

Dentre as três zonas bioclimáticas estudadas, podemos observar grande incidência da radiação solar, detectada nos estudos de insolação realizados principalmente pelo software Ecotect. Somam-se, a esse fato, a ineficiência, inadequações (brises em excesso, mau dimensionados ou sem manutenção) ou inexistência das proteções solares.

Os projetos, em sua maioria, são desenvolvidos por profissionais que não se interessam em realizar um procedimento investigativo do clima local, buscando adaptar a edificação a uma realidade bioclimática mais adequada.

As Avaliações transferem para os gestores e administradores um documento de força que ampara a viabilidade de sua realização. Suas informações possibilitam embasamento técnico, teórico e empírico para a consumação das diretrizes detectadas por APO, Retrofit e Etiquetagem.

A partir destes quadros comparativos, é possível classificar os edifícios conforme as características predominantes e, em sequência, gerar gráficos indicativos da incidência de cada um dos aspectos. Os quadros comparativos, como procedimentos metodológicos, são de fundamental importância para projetistas e comunidade acadêmica avaliarem a qualidade dos projetos utilizados em seus empreendimentos, visando garantir a qualidade do imóvel e a satisfação do cliente, bem como, retroalimentar o processo, no que diz respeito à concepção de projetos futuros.

Ao longo da pesquisa alguns resultados preliminares auxiliaram na formulação de diagnóstico e fundamentação de diretrizes. As questões relativas encontradas foram as seguintes:

- Manuais de manutenção elaborados para um grupo extenso de edificações com plantas e programas diferentes;

- Inexistência de normas relativas ao uso e manutenção de edificações não residenciais;

- Inexistência de banco de dados para ser utilizados por arquitetos para pesquisa de edifícios com tipologias especificas, como, por exemplo, edificações de saúde com subdivisões em suas áreas de atuação (hemocentro, hospital de urgência, maternidade, entre outros);

- Normas municipais, estaduais e federais não conversam entre si, dificultando a elaboração de partido preliminar que atenda a todas elas ao mesmo tempo;

- Dificuldade e morosidade na Aprovação dos Projetos no âmbito municipal, pois sendo a edificação de saúde uma área especifica de conhecimento, a aprovação 
deveria ser realizada por pessoas conhecedoras das normas e com vivência neste tipo de projeto;

- A RDC 50 de 21 de fevereiro de 2002 dispõe de elementos técnicos que regulamentam o planejamento, programação, elaboração, avaliação, e aprovação de projetos físico através de um programa de necessidades básico a ser seguido, caracterizando ambientes, quantidade, dimensão e instalações insuficientes, e não dispõe de sugestão de fluxograma e setorização que padronizem qualquer tipologia de edificação de saúde, deixando em aberto para que órgãos federais, estaduais e municipais possam divergir entre si durante o processo de aprovação e regulamentação, além de expor programa de necessidades incompleto;

- O Brasil encontra-se atrasado em relação ao processo de amadurecimento no exercício de projetação. Ainda no estágio BIM 1.0, nossos projetos não alcançam o estágio de interoperabilidade entre os diversos participantes perdendo muito tempo na coordenação e adequação dos projetos. As etapas avançadas que compreendem simulação termo energética, ventilação, incidência solar e auxilio na gestão e automação predial são capítulos avançados a serem percorridos pelos projetistas brasileiros que desconhecem o programa;

- O cliente é um grande empecilho no processo de implementação do BIM, que desconhece os benefícios do software e acredita que a troca de programas irá atrasar a entrega do projeto ou encarecê-lo;

- A NBR 15575 entrou em vigor, trazendo grande avanço nas questões relativas à qualidade, ao desempenho e à necessidade da boa prática de manutenção das edificações residenciais, deixando bons exemplos para edificações de outras tipologias;

- Ao mesmo tempo que a NBR 15575 está em vigor, é destinada apenas a edificações residenciais, o processo de etiquetagem proposto pelo PROCEL EDIFICA, em busca de uma melhor eficiência energética, aponta melhorias por meio de regulamentações propostas somente para edificações públicas e comerciais;

- A normativa número 2 de 4 de junho de 2014, dispõe sobre regras para a aquisição ou locação de máquinas e aparelhos consumidores de energia pela Administração Pública Federal direta, autárquica e fundacional, e uso da Etiqueta Nacional de Conservação de Energia (ENCE) nos projetos e respectivas edificações públicas federais novas ou que recebam Retrofit, buscando dar exemplo de bons projetos que sejam menos consumidores de energia;

- Nenhuma Norma de Desempenho foi criada especificamente para atender às edificações de saúde.

- Temos no Brasil a cultura da manutenção informal, além da falta de 
especialização da mão de obra, o não cumprimento dos prazos de revisão, e produtos de baixa qualidade;

- A gestão de edifícios nos países desenvolvidos é um trabalho valorizado que movimenta um mercado em ascensão. No Brasil, o trabalho de gestão de edificações ainda é desconhecido e pouco valorizado. Falar em gestão especializada em tipologias de edificações trata-se de uma realidade ainda distante;

- Ao iniciar um estudo preliminar, os profissionais envolvidos não realizam a devida análise do entorno e ambiental da área buscando tanto uma adequação mais harmônica ao terreno, entorno, clima, cultura como também não são valorizadas as características climáticas locais em busca de maior economia de recursos naturais em busca de conforto ambiental;

- As adequações que a edificação recebe com o tempo para que os efeitos climáticos negativos sejam amenizados geram novos problemas e novos custos, como por exemplo, a utilização de insulfilm nas janelas evitando a entrada de radiação solar deixando o ambiente escuro, provocando maior utilização de iluminação artificial em um local onde a iluminação natural seria suficiente se fosse estudada de maneira correta;

- É frequente observar que os projetos executados possuem problemas no sistema de iluminação. As ocorrências mais comuns são: iluminação em excesso; falta de aproveitamento da iluminação natural; uso de equipamentos com baixa eficiência luminosa; falta de comandos (interruptores) setorizados, ausência de manutenção, depreciando o sistema e hábitos de uso inadequados (não é uma característica do projeto, mas ocorre);

- A maior parte do consumo energético das edificações de saúde é a refrigeração, seguidos de equipamentos, climatização e iluminação. Os materiais implantados para o funcionamento da edificação não possuem etiquetagem que garanta menor consumo, como é o caso do selo tipo A (Gráficos 14, 15 e 16).

Gráfico 14: Quadro de Consumo Energético do HEMODF

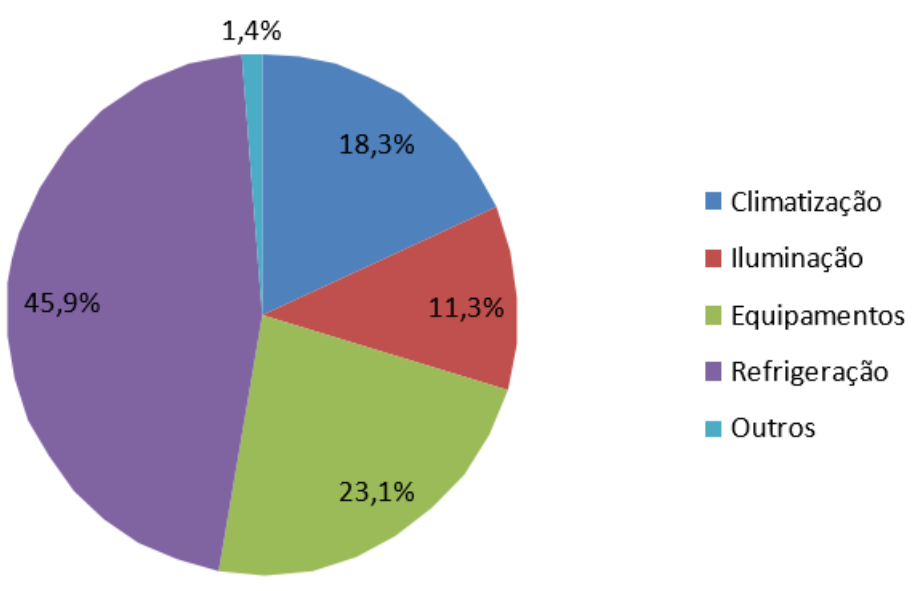

Fonte: LASUS, 2011. 
Gráfico 15: Quadro de Consumo Energético do HEMORGS

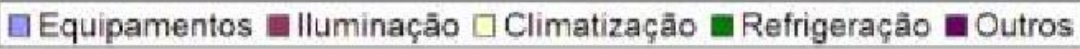

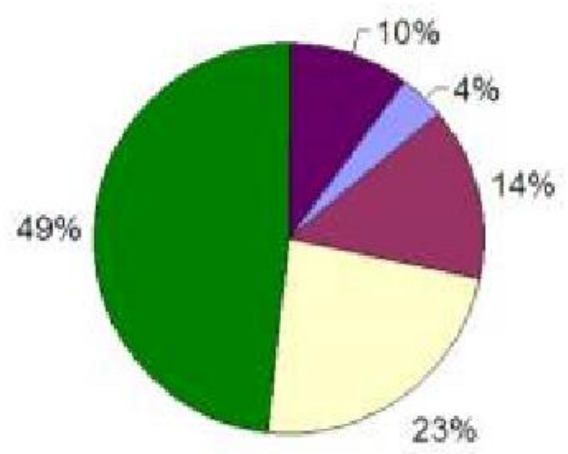

Fonte: LASUS, 2015.

Gráfico 16: Quadro de Consumo Energético do HEMOAM

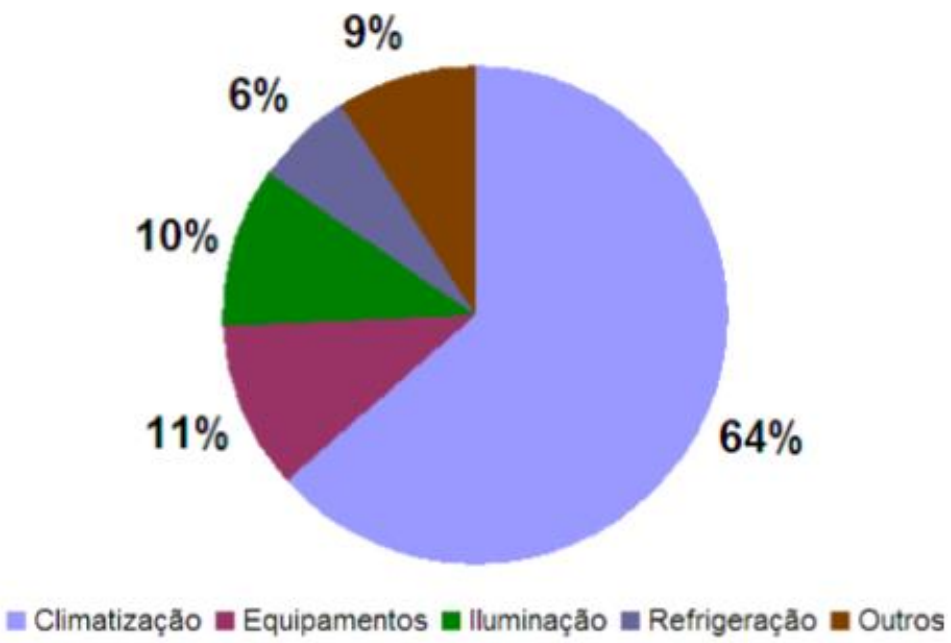

Fonte: LASUS, 2014.

- Em muitas das situações analisadas, o desconforto térmico é um dos itens de insatisfação por parte dos usuários. A temperatura elevada leva ao uso constante de aparelhos de ar condicionado. No entanto, esses não são regulados a fim de manter uma temperatura ambiente agradável, causando desconforto novamente pela baixa temperatura

- Diante do crescimento da população também aumentou o índice de sangue utilizado em procedimentos hospitalares, mas as doações de sangue não cresceram na mesma proporção, realidade que dificulta atingir e manter o índice ideal de estoque de sangue nos bancos de sangue conforme recomendações da OMS, estando o estoque sempre abaixo do índice ideal.

Portanto, é urgente a necessidade de modificar este cenário e alavancar possibilidades de amenizar, se não for possível sanar esta deficiência, considerando que todo cidadão é um cliente em potencial a necessidade deste líquido precioso e insubstituível. Os hemocentros investem em campanhas de conscientização, que dão 
retorno imediato, mas, é preciso abrir o leque de possibilidades, aproveitar a demanda da tecnologia e da informação para investir em inovação e mudar o cenário do índice dos estoques de sangue nos Hemocentros. A falta de investimento na estrutura física dessas edificações também é um fator significativo nesse aspecto, já que não se tratam de ambientes agradáveis ambientalmente e visualmente. Nada acolhedores, os Hemocentros perdem doadores.

\section{RESULTADOS FINAIS}

A partir dos resultados preliminares, com a intenção de objetivar o trabalho, foram desenvolvidas propostas e diretrizes visando formular leis e normas técnicas que auxiliem os projetistas no processo de projetação de Hemocentros ou de edificações similares.

Normas que buscam, além da possibilidade de diminuição dos erros, maior grau de acertos e descobertas projetuais. Ações que tragam para essa tipologia maior eficiência energética, fluxograma e setorização mais bem resolvidos como sugestão para arquitetos e engenheiros que ainda não tem experiência com projetos em EAS.

Tais normas podem também abarcar temas bioclimáticos e de sustentabilidade como maior adequação do partido ao clima local, conforto, reuso de água, utilização de equipamentos que consomem menos energia e principalmente o incentivo de hábitos que possibilitem inclusão do usuário na vida da edificação, conhecendo esses recursos economizadores de recursos naturais.

Melhores possibilidades de manutenção, maior esclarecimento e conscientização a respeito da tipologia, do uso e gestão, maior durabilidade da edificação, facilidade na adequação a novas tecnologias, e utilização de softwares que facilitam o processo para novas reformas.

As indicativas de sugestões projetuais são apresentadas a seguir, possibilitando a reformulação em leis e normas técnicas existentes, estratégias de projetação que possam embasar discussões a respeito do tema, auxiliando na melhoria do resultado do projeto, diminuindo tempo e gerando economia de forma generalizada. A intenção não é somente indicar estratégias, mas gerar um maior campo de discussão sobre o assunto em busca de encontrar novos caminhos e abandonar velhos hábitos de trabalho.

Durante a análise da RDC 50, foi possível perceber que não há uma setorização e fluxograma que possa auxiliar no processo de projetação de Hemocentros. Pelas análises realizadas nas avaliações feitas pelo LASUS, nas três unidades estudadas e, também, em visita ao Hemocentro de Goiânia foi possível realizar a elaboração de gráficos sugestivos de usos e fluxos, que auxiliam na melhor adequação dessa tipologia projetual. Percebeu-se a 
existência de três setores de trabalho que configuram um Hemocentro (Figura 21)

Figura 17: Sugestão de Fluxograma para elaboração de projetos de Hemocentros

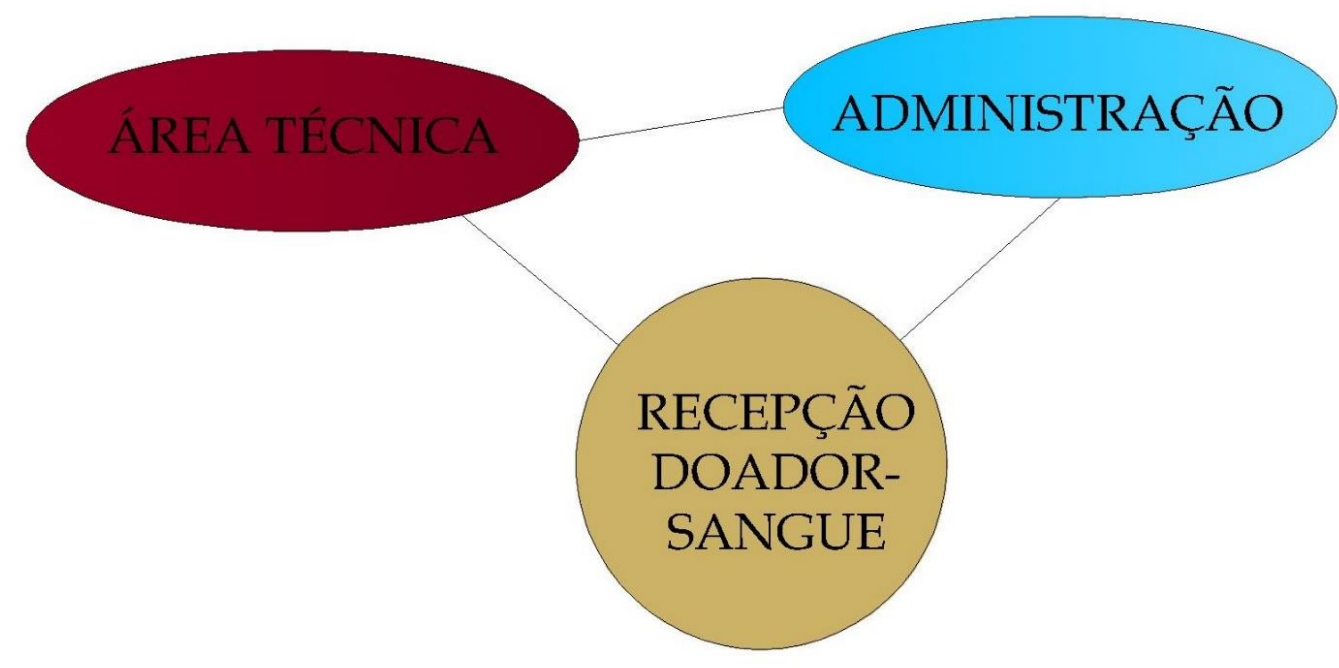

Fonte: Elaborado pela autora, 2016.

O setor recepção-doador engloba a entrada do doador na edificação, sua identificação, triagem, coleta, recuperação e sua saída pela lanchonete. O doador não tem acesso direto à área administrativa ou à área técnica, mas os funcionários de outras áreas podem ou não ter esse acesso, direta ou indiretamente. Esses acessos devem ser realizados por antessalas, balcões e óculos para evitar o fluxo desnecessário de usuários que não fazem parte do corpo técnico e que não estejam equipados para acesso a certos ambientes, visando evitar contaminação dos ambientes.

Neste setor podemos citar alguns ambientes que são poderão ou não existir nos Hemocentros. São eles: Posto de cadastro, sala de espera de doadores, posto de registro, sala de espera triagem-coleta, triagem, sala de coleta, recepção do sangue, sala de recuperação, lanchonete.

Espera-se que os projetos contemplem entrada e saída com acessibilidade e cobertura para proteção contra intempéries independente do clima no qual se encontra e que a recepção e espera sejam confortáveis e agradáveis causando boa impressão nos doadores. Se possível, implantar área de convivência humanizada, com acesso a luz e ventilação natural, e vegetação com o intuito de deixar o espaço mais agradável ainda.

O setor área técnica retira as bolsas de sangue do setor recepção doador sangue e as leva para o tratamento laboratorial. Os ambientes que podem compor este setor são: câmara fria, laboratório de sorologia, recepção do sangue e processamento, sala de hemovigilância, sala de produção, sala de utilidades, sala de utilidades, sala de estocagem de hemocomponentes liberados, sala de estocagem de hemocomponentes não liberados, sala de imunohematologia do doador, laboratório para biologia molecular, sala do responsável técnico, controle de qualidade e produto final, distribuição externa, 
estacionamento distribuição de sangue.

A circulação do sangue retirado no setor recepção doador-sangue pode ser realizada através de barreiras arquitetônicas visuais e físicas, como óculos, ante-salas, antecâmaras buscando não cruzar fluxos, evitando acidentes.

Grande parte da comunicação interna desses três setores pode ser realizada por um sistema computadorizado, o que não impede a passagem de documentos e trânsito de material entre eles. No entanto, essa circulação é monitorada como em toda edificação de saúde evitando, contaminação, acidentes de trabalho e disseminação de doenças.

No setor administrativo há a sugestão de alguns ambientes como: recepção da administração, manutenção, almoxarifado, segurança, quarto plantonista, cozinha, refeitório, biblioteca, sala de reunião e vídeo conferência, tecnologia da informação, ouvidoria, recepção empresas, contratos e convênios, recursos humanos, direção, administração, área de convivência, auditório, estacionamento funcionários.

Os fluxogramas foram elaborados por setores buscando separar acessos e saída de pessoas e produtos, com o intuito de proporcionar o cruzamento ou não desses últimos e dos usuários das diferentes áreas. (Figuras 22, 23 e 24)

Figura 18: Fluxograma sugerido para o Setor Recepção-Doador-Sangue

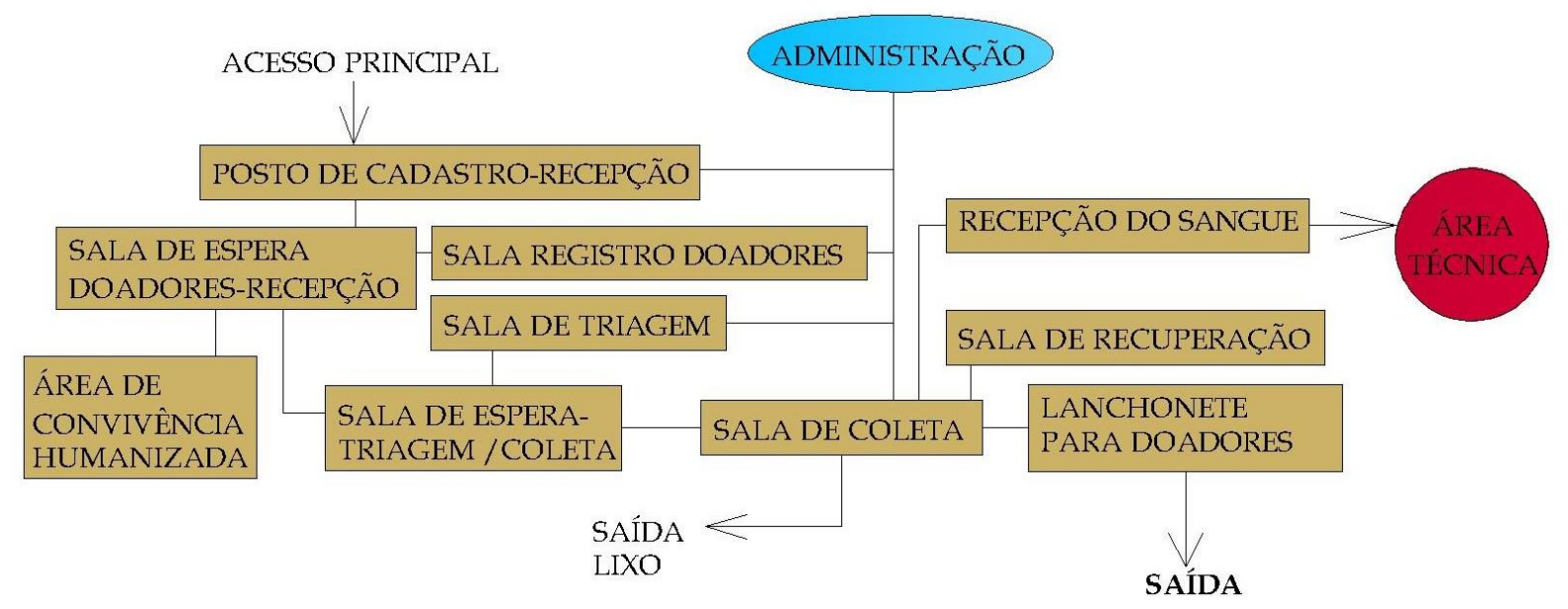

Fonte: Elaborado pela autora, 2016. 
Figura 19: Fluxograma sugerido para Setor Administrativo

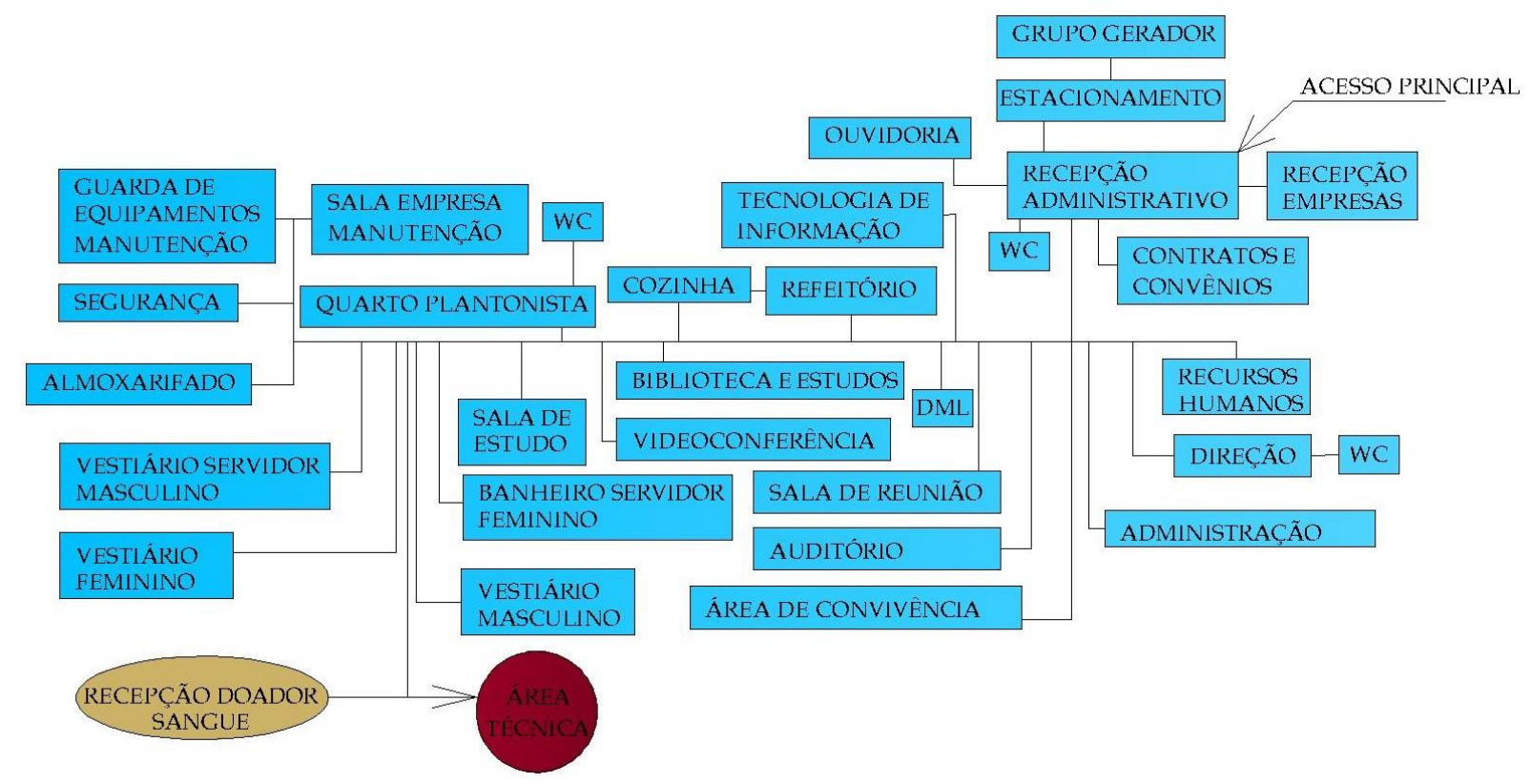

Fonte: Elaborado pela autora, 2016.

Figura 20: Fluxograma sugerido para a área técnica

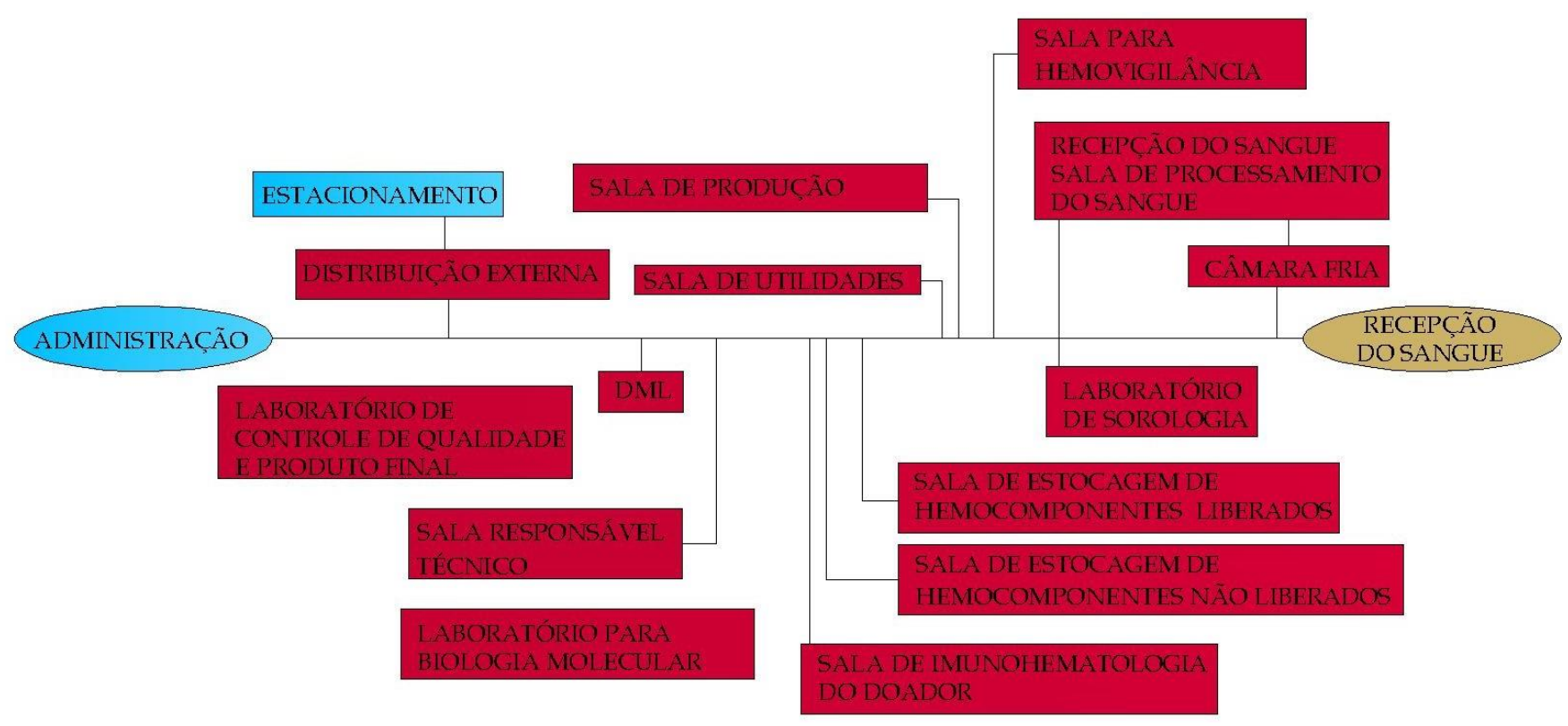

Fonte: Elaborado pela autora, 2016.

Como podemos observar nas plantas das edificações estudadas e em algumas EAS, o uso de blocos para uso no partido arquitetônico e modulação é uma constante. Esse desenho auxilia em caso de mudanças e acréscimos de plantas, aumentando área sem alterar formato original, facilitando mudanças e acréscimo de instalações.

Desse maneira, o Hemocentro de Brasília foi disposto, em dois blocos A e B, a circulação é realizada por uma passagem coberta, no entanto essa passagem mostra-se 
problemática nos períodos chuvosos, pois não protegem os transeuntes.

Uma área de convivências para funcionários e usuários foi criada no novo projeto objetivando a utilização da área externa que será tratada paisagisticamente e também proporcionando convívio e humanização.

Depósito químico, depósito de inflamáveis e resíduos sólidos subestação, e grupo gerador foram locados na área externa a edificação, de maneira a não atrapalhar a fachada frontal e objetivando melhor fluxo.

No corredor criado pelo bloco B podemos perceber o local onde ficam as condensadoras, ambiente gerador de calor e ruídos, que interfere no conforto dos usuários que trabalham próximos a essa área (Figura 25).

Figura 21: Fluxo Hemocentro de Brasília

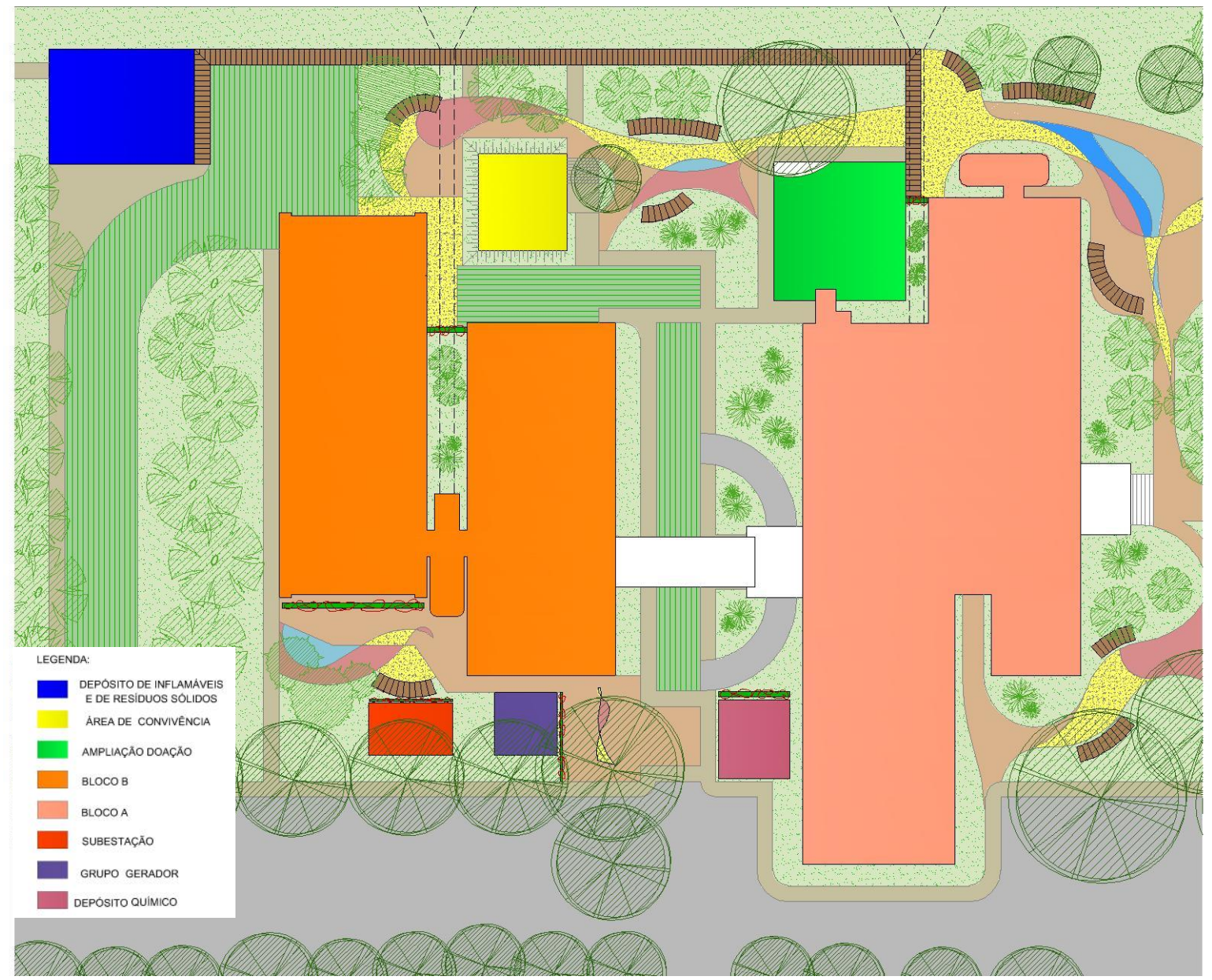

Fonte: Alterado pela autora, 2017.

O fluxo Recepção doador-sangue do Hemocentro de Brasília obedece às normas norteadas pela Vigilância Sanitária e pode se tornar base para projetos semelhantes (Figura 22). 
Figura 22: Fluxo Hemocentro de Brasília

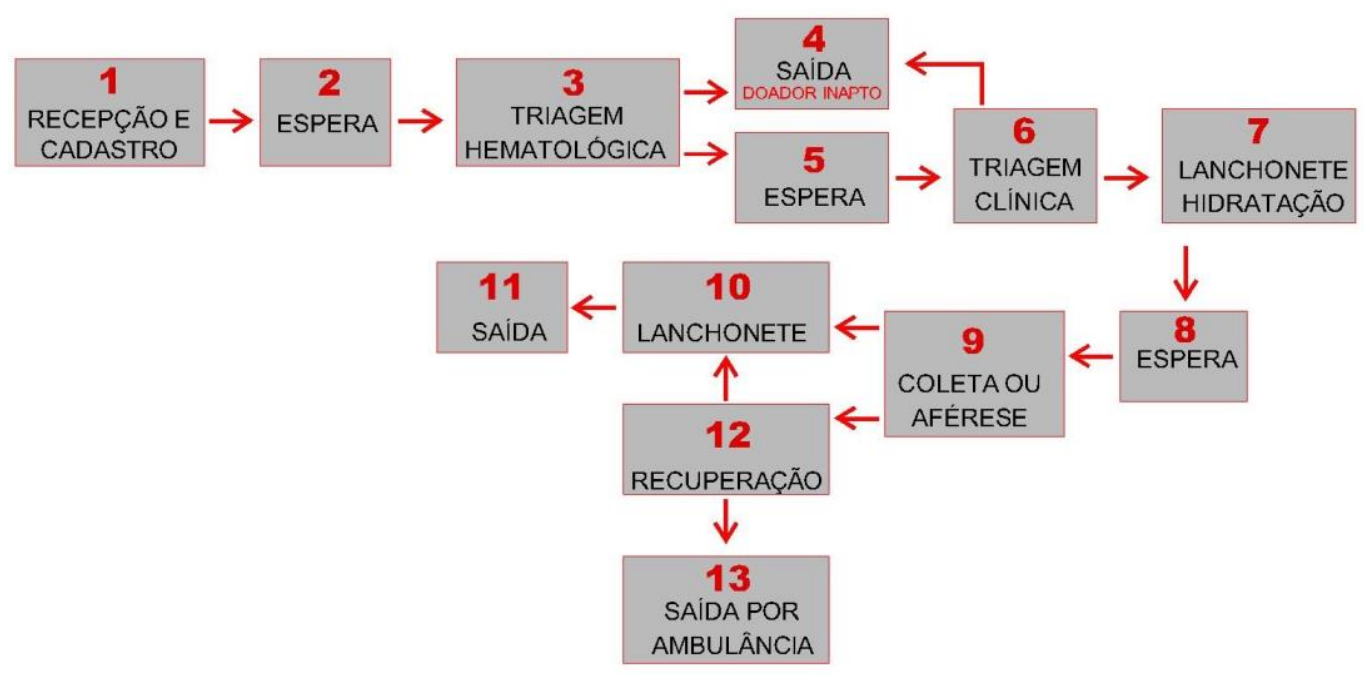

Fonte: Elaborado pela autora, 2017.

É importante observar a amplitude da recepção destinada à espera dos doadores do HemoDF. Salientar que o conforto desses usuários é imprescindível para a sobrevivência dos Hemocentros e de toda a rede de EAS abastecida pelo sangue ali coletado. As recepções devem ser agradáveis, amplas, ventiladas e de maneira a gerar conforto no usuário, provida de materiais de acabamento leves, que demonstrem limpeza, asseio, mobiliário de qualidade, garantindo adequada ergonomia, facilidade de acesso a todos os portadores de mobilidade reduzida e proteção às influências climáticas locais (Figura 23).

Figura 23: Planta de Setorização-Ambientes Hemocentro de Brasília

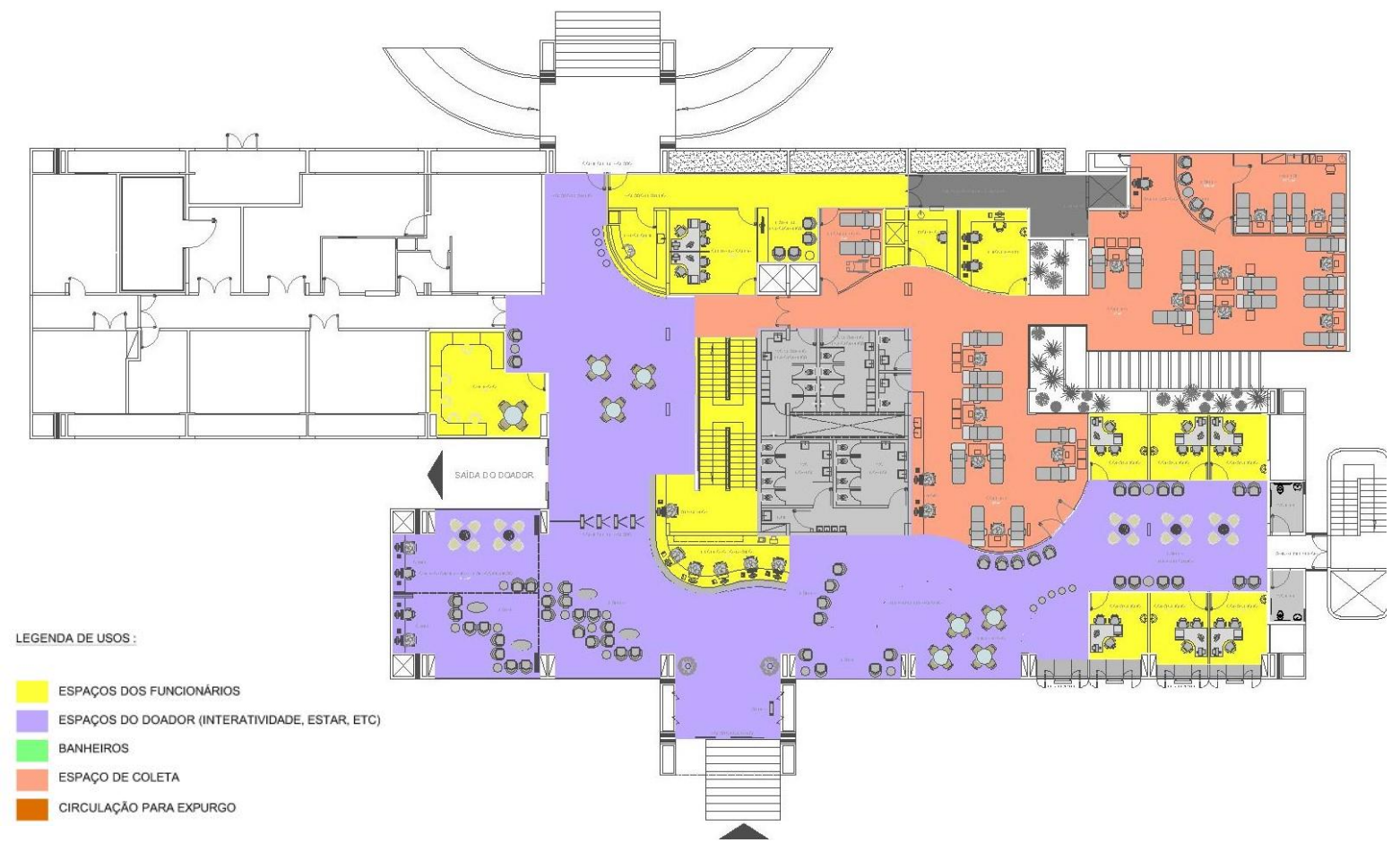

Fonte: Alterado pela autora, 2017. 
No Hemocentro de Manaus é possível observar os blocos e a circulação entre eles é feita através de coberturas. A implantação anterior ao projeto de intervenção mostra alguns blocos e áreas descobertas e sem tratamento paisagístico. Área que fica atualmente em desuso. A nova implantação expõe áreas verdes, caminhos tratados com pavimentação adequada, possibilidade de sombreamento e coberturas, pontos com água e contemplação (Figuras 24 e 25).

Figura 24: Implantação do Hemocentro de Manaus antes da AAI

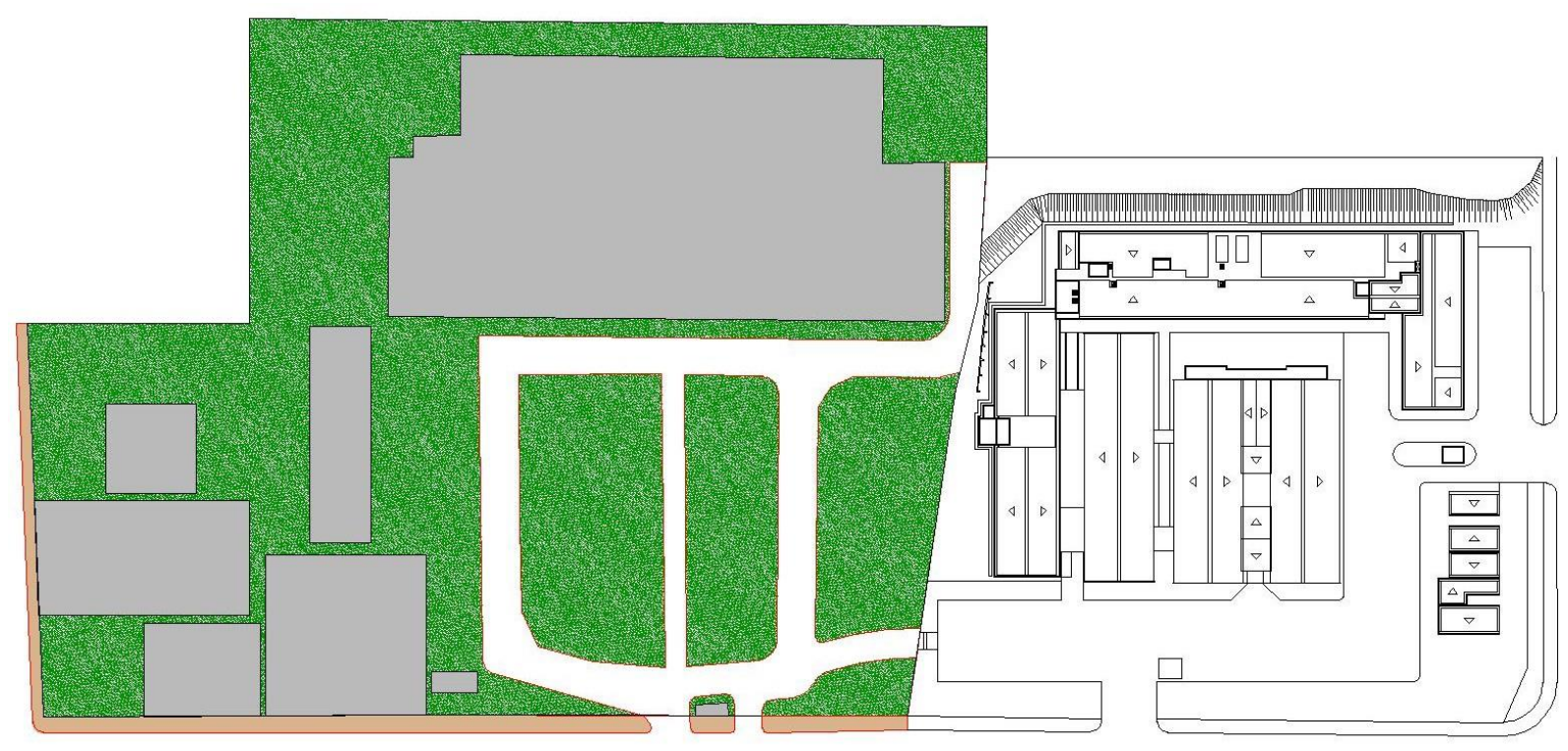

Fonte: Alterado pela autora, 2017.

Figura 25: Implantação do Hemocentro de Manaus após a AAI

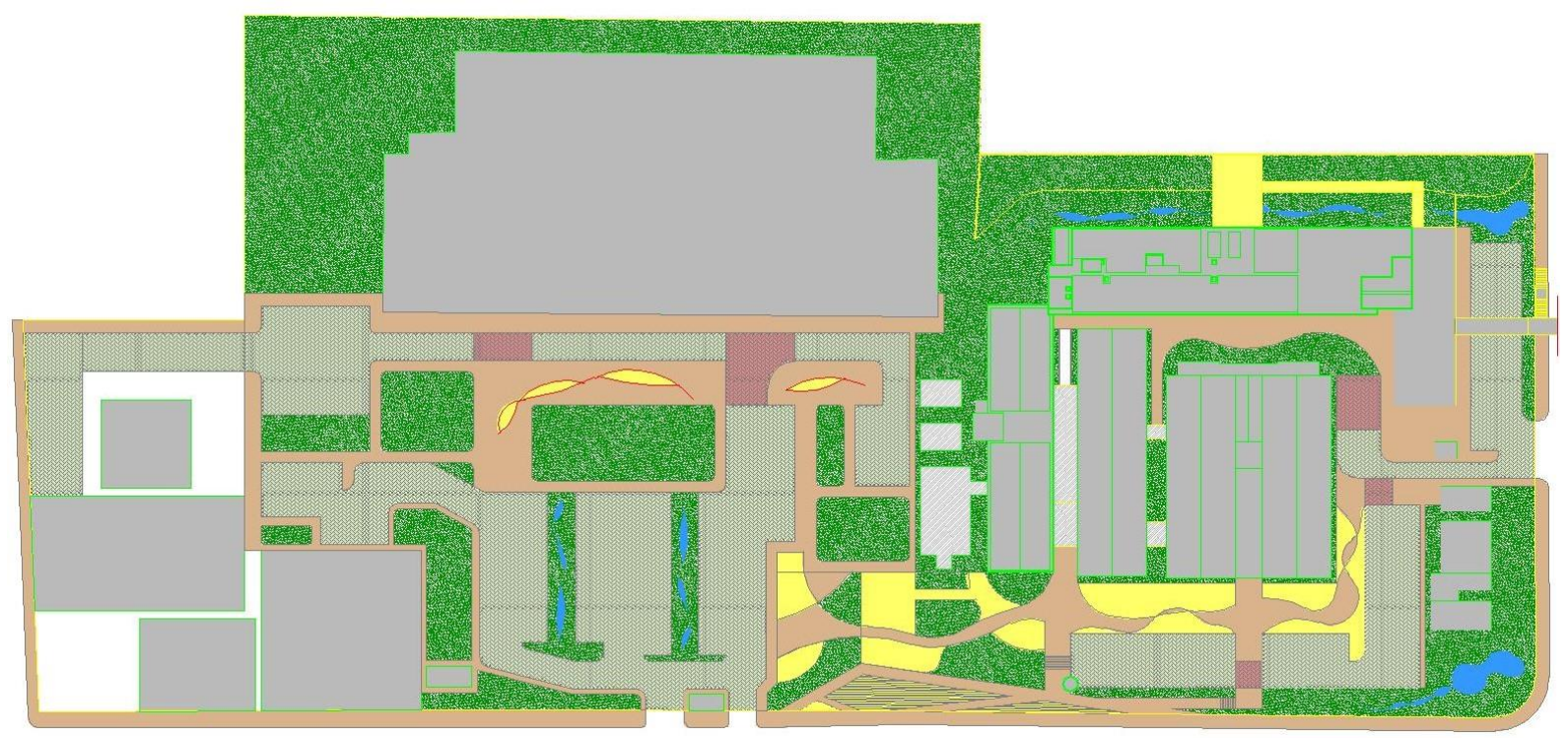

Fonte: Alterado pela autora, 2017.

No maior Hemocentro estudado temos uma clara separação de atividades através dos blocos e pavimentos. No pavimento térreo, além dos setores de área técnica, 
administrativo e recepção doador-sangue, há uma grande área destinada ao setor ambulatorial, onde são realizadas consultas e exames hematológicos.

No primeiro pavimento, setores administrativo e área técnica. No segundo pavimento, a área de internação do setor ambulatorial e também uma grande área destina ao estudo e ensino com salas de treinamento, aula, estudos e auditório. No terceiro pavimento, somente área administrativa. (Figura 26)

Figura 26: Pavimento térreo, primeiro, segundo e terceiro pavimentos do Hemocentro de Manaus

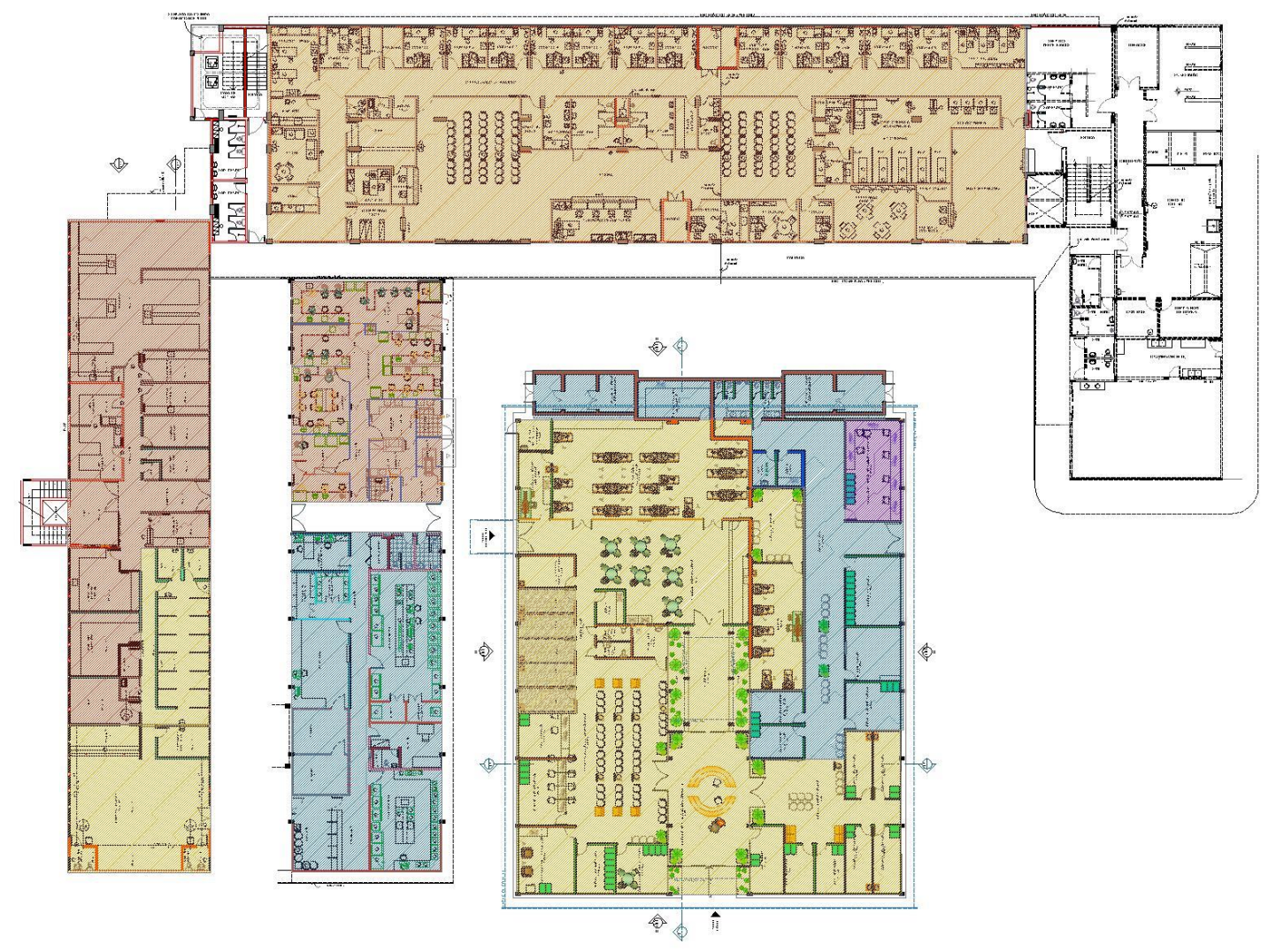



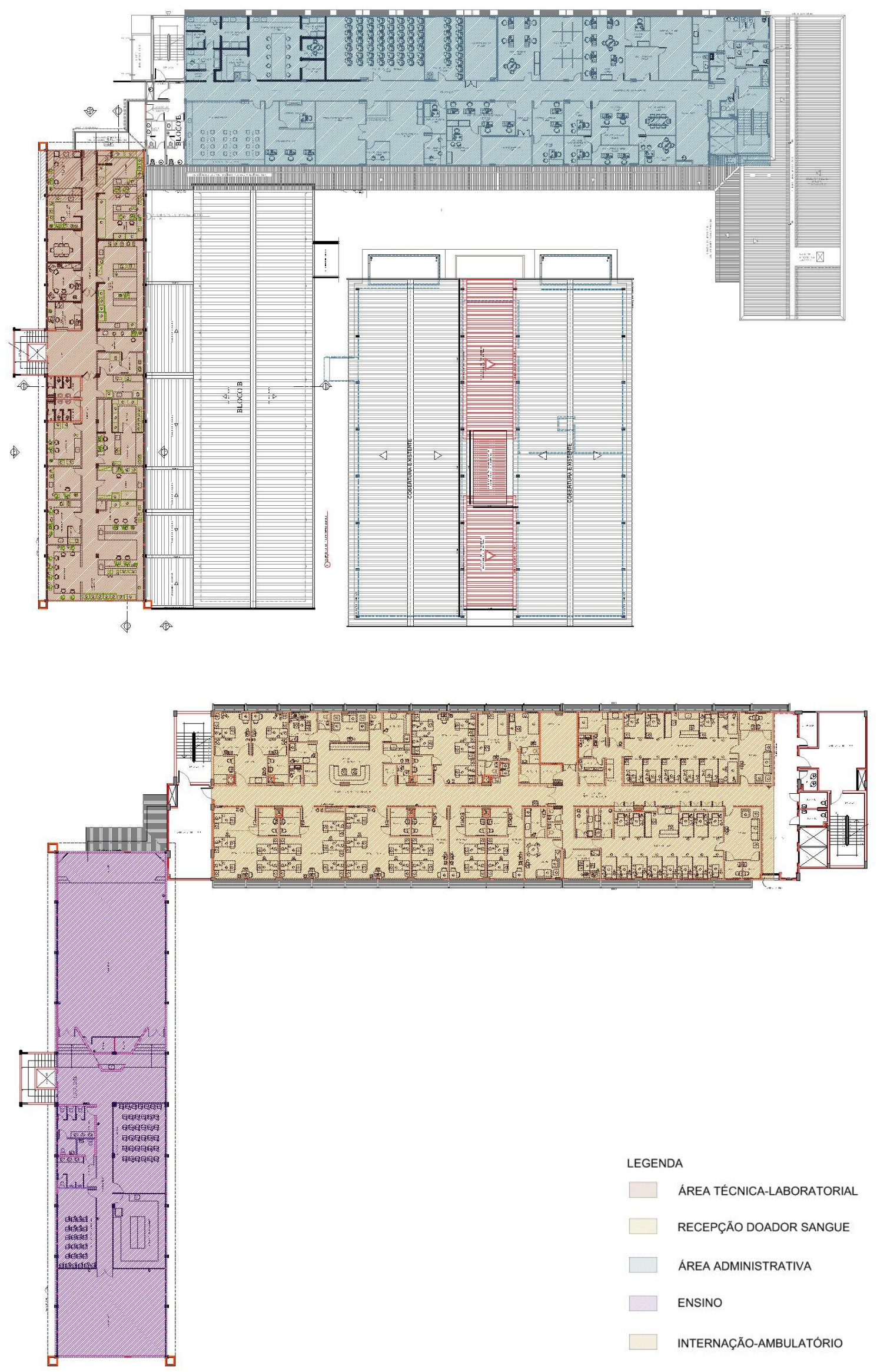


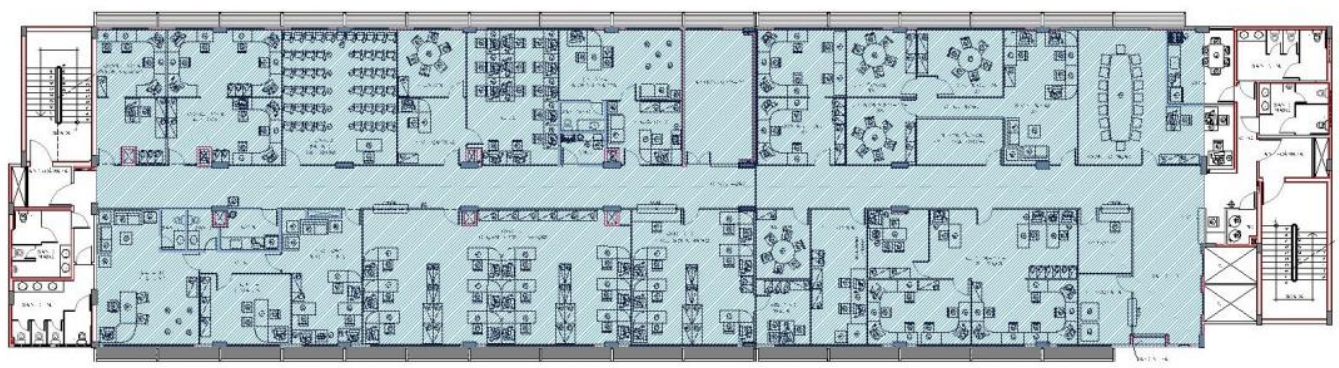

Fonte: Alterado pela autora, 2017.

A área a ser acrescida no Hemocentro de Porto Alegre contará com quatro setores, administrativo, recepção doador-sangue, área técnica e ambulatório.

Os blocos serão interligados entre si através de cobertura com forma orgânica e de baixa altura para a proteção dos transeuntes. As áreas ajardinadas e de convivência, que constam nas AAls de Brasília e Manaus também existe no projeto do HEMORGS. (Figura 27)

Figura 27: Implantação Hemocentro Porto Alegre

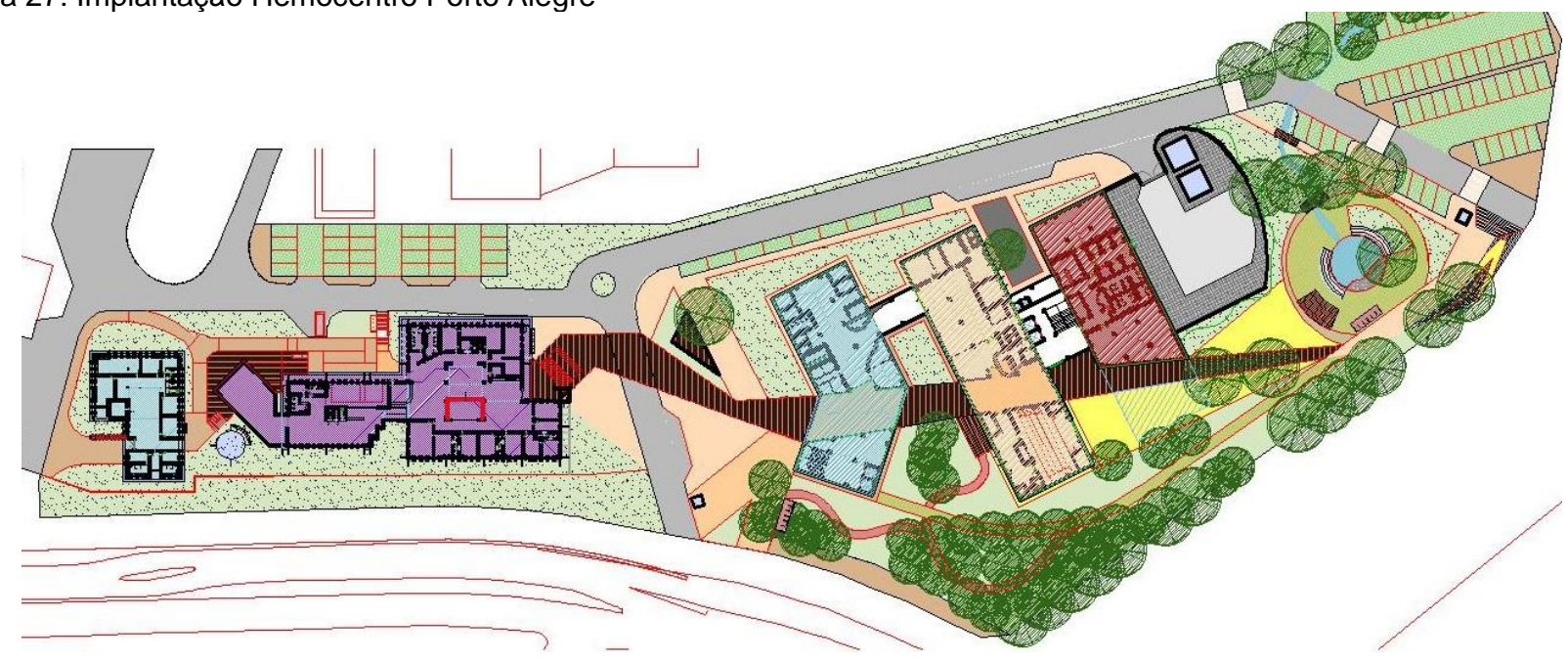

LEGENDA:

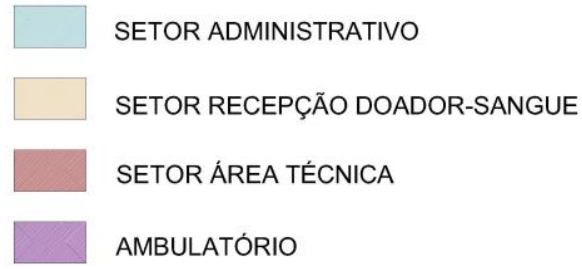

Fonte: Alterado pela autora, 2017.

Objetivando obter melhorias na iluminação e ventilação da edificação, a AAl do Hemocentro de Porto Alegre propõe a execução de sistema passivo de resfriamento da edificação. Este sistema, proporciona entrada da luz natural através de domus. Essa ação objetiva diminuir a utilização de iluminação artificial, provoca a entrada de ar frio e saída do ar quente, reduzindo a utilização de resfriamento artificial dos ambientes. Ações como está diminuem consideravelmente o custo com contas de energia e aumentam a vida útil do edifício. 
Figura 28: Sistema de lluminação e Ventilação - HEMORGS

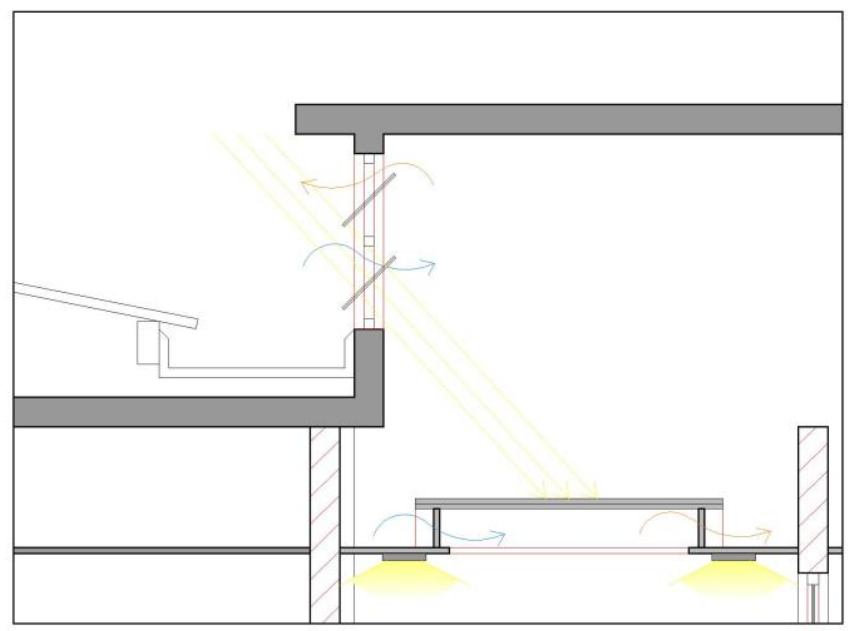

Fonte: Alterado pela autora, 2017.

Outros fluxogramas também podem ser sugeridos para EAS, (Figura 29), entre eles a elaboração de um plano de manutenção. O plano sugere que, em primeiro lugar, seja definida a edificação específica, na qual sejam identificados os sistemas constituintes da edificação, a organização desses sistemas, visando uma periodicidade de manutenção, estabelecendo rotinas e procedimentos e uma sistemática de controle.

Elaborando um sistema de manutenção, os gestores podem ter maior controle e organização, observando a qualidade e a periodicidade. Dessa maneira, fica estabelecida entre o gestor e a edificação uma relação de conhecimento íntimo que permite solucionar e identificar os pontos de maior gasto de energia, equipamentos que precisam de substituição, adequação ou reforma. O objetivo é que a edificação funcione de maneira mais eficiente e mais confortável para os usuários.

Figura 29: Fluxograma sugerido para Elaboração de Plano de Manutenção

\section{PLANO DE MANUTENÇÃO}

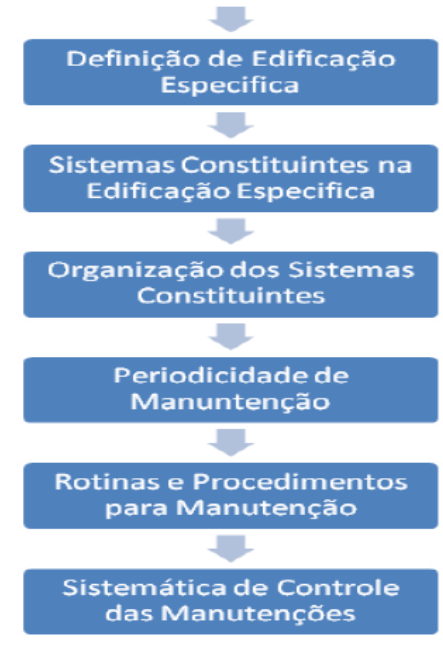

Fonte: Campos e Vargas, 2014.

Ao elaborar o sistema de manutenção, durante o período de manutenções, há a 
necessidade de agendar, marcar e conferir as datas de cada manutenção. Esse quadro sugestivo auxilia os gestores a cumprirem os prazos de manutenção de cada sistema sem extrapolar datas, objetivando maior economia e conforto. A periodicidade da manutenção auxilia na gestão dos edifícios de saúde assim como de várias outras tipologias. (Quadro 10)

Quadro 6: Periodicidade dos sistemas de manutenção

\begin{tabular}{|c|c|c|c|c|c|c|c|c|}
\hline \multirow{2}{*}{ SISTEMA } & \multicolumn{7}{|c|}{ MESES } & \multirow{2}{*}{$\begin{array}{c}\text { APÓS } 5 \\
\text { ANOS }\end{array}$} \\
\hline & \begin{tabular}{|l|l|}
6 & 12 \\
\end{tabular} & \begin{tabular}{|l|l|}
18 & 24 \\
\end{tabular} & \begin{tabular}{l|l|l}
4 & 30 \\
\end{tabular} & 36 & 42 & 48 & \begin{tabular}{c|c|cc}
54 & 60 \\
\end{tabular} & \\
\hline Reservatórios & & & & & & & & Cada 12 Meses \\
\hline Alvenaria de Vedaçăo & & & & & & & & Cada 24 Meses \\
\hline Elevadores & & & & & & & & Cada 12 Meses \\
\hline Portôes & & & & & & & & Cada 12 Meses \\
\hline SPDA & & & & & & & & Cada 12 Meses \\
\hline Iluminaçăa de Emergência & & & & & & & & Cada 6 Meses \\
\hline Instalaçőes Elétricas & & & & & & & & Cada 12 Meses \\
\hline Instalaçőes Hidráulicas & & & & & & & & Cada 12 Meses \\
\hline Instalaçőes de Gás & & & & & & & & Cada 12 Meses \\
\hline Impermeabilizaçăo & & & & & & & & Cada 12 Meses \\
\hline Esquadrias de Madeira & & & & & & & & Cada 12 Meses \\
\hline Esquadrias de Alumínio & & & & & & & & Cada 12 Meses \\
\hline Antenas Coletivas & & & & & & & & Cada 12 Meses \\
\hline Estrutural & & & & & & & & Cada 24 Meses \\
\hline Louças Sanitárias & & & & & & & & Cada 12 Meses \\
\hline Caixas e Válvulas de Descarga & & & & & & & & Cada 12 Meses \\
\hline Interfones / Telefonia & & & & & & & & Cada 12 Meses \\
\hline Sistema de Segurança & & & & & & & & Cada 12 Meses \\
\hline Revestimentos Cerâmicos & & & & & & & & Cada 12 Meses \\
\hline Piso Cimentado & & & & & & & & Cada 36 Meses \\
\hline Pintura & & & & & & & & Cada 36 Meses \\
\hline Vidros & & & & & & & & Cada 12 Meses \\
\hline Cobertura & & & & & & & & Cada 12 Meses \\
\hline Instalaçōes de Combate a Incêndio & & & & & & & & Cada 6 Meses \\
\hline
\end{tabular}

Fonte: Campos e Vargas, 2014.

Dentre os Sistemas das edificações, observam-se uma série de recomendações, conforme seguem:

Quanto ao sistema de iluminação, observa-se grande consumo energético das edificações. Em busca dessa diminuição devem ser propostos limites de etiquetas e índices de consumo para edificações de saúde, o que acarretaria, além de uma conscientização maior dos usuários, melhor uso dos aparelhos e nortearia a compra de produtos tipo selo $\mathrm{A}$. Algumas ações preliminares conforme as normas seriam: troca das lâmpadas existentes por lâmpadas de Led, implementação de sensores de presença para os sistemas de iluminação, de segurança, acionamento de portas e climatização.

A luz natural possui grande importância nos ambientes, não apenas por possibilitar a economia de energia, mas por proporcionar uma série de vantagens aos usuários, tais como: confere senso de especialidade, propicia vivacidade ao edifício, um bom ambiente visual, por ser a melhor reprodutora de cores. Sendo assim, em busca de um melhor aproveitamento da iluminação natural, sugerem-se algumas medidas para implementação em edificações de saúde como: segmentar o sistema elétrico das luminárias próximas às janelas e disponibilizar interruptores para estas luminárias, permitindo que 
fiquem apagadas quando existir iluminação natural suficiente e implantar sistemas de controle de iluminação com sensores de luminosidade e reatores eletrônicos dimerizáveis nas luminárias próximas às janelas.

Caso sejam adotados sensores de luminosidade e reatores eletrônicos dimerizáveis, o controle da iluminação artificial deve ser automático e gradual, conforme os níveis de iluminância provenientes da luz natural. Nesse caso, o sistema de controle utiliza a iluminação natural disponível, mantendo a iluminância requerida para cada atividade no plano de trabalho constante.

Oferecer, através de norma para edificações de saúde, recomendações a respeito da iluminação como: sistemas que utilizam lâmpadas de 32 e $28 \mathrm{~W}$; segmentar os circuitos em grupos menores de luminárias, principalmente em ambientes amplos, dividindoos por linhas de luminárias próximas e afastadas das janelas e de forma a criar pequenos grupos independentes de trabalho; segmentar o sistema elétrico das luminárias próximas às janelas, permitindo que estas fiquem apagadas quando os níveis de iluminância forem aceitáveis; disponibilizar aos usuários acesso aos interruptores a todas as salas que não o possuem ou sistemas de controle de iluminação por meio de sensores de presença; alterar o layout das estações de trabalho de modo que as telas dos computadores fiquem sempre que possível em posição lateral às janelas, evitando-se ofuscamentos nestas áreas de trabalho, permitindo a utilização da iluminação natural; adotar programas para conscientização e educação dos funcionários sobre a importância de se conservar energia e de que forma podem-se evitar desperdícios.

Quanto aos sistemas de climatização, tem-se que, em grande parte dos Hemocentros, unidades autônomas denominadas "splits" de diferentes capacidades. Está havendo um movimento de troca para sistemas de climatização tipo "split" em diversas áreas por equipamentos mais novos. Porém, essa troca muito vezes não levou à aquisição de equipamentos mais eficientes (selo PROCEL EDIFICA A). Sugere-se que, quando novas aquisições forem realizadas, que seja considerada a classificação do equipamento quanto ao selo energético e que sejam adquiridos apenas equipamentos de nível $\mathrm{A}$ para todas as edificações de saúde públicas.

Em relação à aplicação do BIM, recomenda-se que durante os processos licitatórios para edificações de saúde públicas possa haver obrigatoriedade de projetos com o novo software, visando beneficiar com conforto e baixo custo de manutenção.

Com a implementação do Software Revit ou outros aplicativos será possível simular e possibilitar análises quanto às condições e qualidade ambiental das edificações. Obrigando seu uso, o poder público tem maiores possibilidades de realizar uma construção mais acertada em relação às adequações futuras, e do projeto ser interoperável, pelas várias disciplinas, mas também viabiliza uma avaliação ambiental do projeto através de 
simulação computacional. Essa validação pode ser regulada por meio da quantificação da velocidade e da incidência da ventilação natural, comportamento da ventilação no edifício, análise da incidência solar e eficiência das proteções (brises), entre outros elementos da envoltória do edifício e sua relação com o entorno.

Quanto à APO, recomenda-se que seja praxe nos Planos de Manutenção dos EAS da Hemorrede, visando, sobretudo, adequações mediante reformas e adaptações, além de proporcionar melhor qualidade ambiental e interface com o usuário.

Em se tratando de Etiquetagem, também indica-se sua obrigatoriedade em projeto de edificações novas e nas existentes suscetíveis a reformas e a adaptações; também, recomenda-se o incentivo fiscal a edificações existentes que se propuserem a ser etiquetadas em busca de uma melhora de Selo. Dessa forma, seria desenvolvido um processo de troca, onde todos sairiam ganhando, e seria possível criar uma série de exemplos reais e próximos à realidade do cidadão comum que busca a redução de consumo energético e adequação à realidade ambiental mundial.

É importante também proporcionar cursos e certificações de fácil acesso para profissionais de Arquitetura e Urbanismo para que possam trabalhar em um novo nicho de mercado, desenvolvendo novas práticas e a possibilidade de divulgação deste modelo; além disso, deve-se incentivar normas que obriguem, de forma gradativa, que as edificações particulares só possam ser vendidas ou alugadas se obtiverem a etiquetagem da edificação. Essa prática classificaria as edificações com maior qualidade como as menos consumidoras de energia, valorizando seu custo de aluguel e de venda;

O Retrofit é outra prática que de destaca, em que se busca preservar o patrimônio, reabilitando edificações comerciais, residenciais, públicas e industriais com o objetivo de valorizar edificações mais antigas, aumentando a sua vida útil com a incorporação de avanços tecnológicos e utilizando materiais de última geração, desenvolvendo assim uma prática mais econômica e mais eficiente que a demolição, que geraria grande quantidade de lixo e resíduos, tornando-se uma prática sustentável.

A análise do clima deve ser uma das prerrogativas para a elaboração de projetos de edificações novas ou adequação das existentes, visando por meio de cursos, incentivar e divulgar normas para projetação com observação em relação ao clima, através de entidades, tais como Conselho de Arquitetura e Urbanismo (CAU), Conselho Regional de Engenharia e Arquitetura (CREA), Prefeituras, entre outros.

Os projetistas deveriam, durante a fase de projetação, analisar os aspectos climáticos da edificação em processo de aprovação. Para tanto, é necessária a divulgação do conhecimento para toda a comunidade da construção, desde alunos até os órgãos públicos, responsáveis pela análise e aprovação de projetos. Recomenda-se também a obrigatoriedade para que projetos de EAS obedeçam a estratégias projetuais estabelecidas 
pela NBR 15220, de acordo com o clima local do projeto a ser desenvolvido. Essa medida visa maior conformidade entre projeto e clima para as edificações de saúde, além de proporcionar maior vida útil e menor custo de manutenção para esta tipologia.

O Brasil é um país com diversas zonas climáticas e culturais, no entanto, podemos observar que grande parte das edificações não se encaixa com as características locais. Foi possível perceber que além de uma arquitetura pouco convidativa, os Hemocentros não possuem um tratamento paisagístico agradável e que amenizassem os desconfortos climáticos e ambientais. Segundo Mascaró (2002), as formas que compõem a paisagem, a natureza, deveriam ser aproveitadas para criar uma continuidade entre o espaço natural e o construído, permitindo que a cidade se inscrevesse com facilidade no meio natural, produzindo, assim, uma transição gradual do puramente construído, do artificial para o natural através de matizes da paisagem, com a sua carga de transformações, confirmações ou contraposições. No entanto, o foco de um projeto é sempre a parte edificada, que não se comunica com o paisagismo e a área externa.

As análises de projetos pela Anvisa também deveriam abordar a intervenção paisagística, áreas de convivência internas e externas às edificações, áreas de acesso e transição com especificação de espécies vegetais naturais do clima a serem inseridas, melhorando a qualidade ambiental através da restrição aos ganhos solares, promoção do resfriamento evaporativo, alteração dos materiais em vistas a qualidade ambiental, qualificação do espaço com mobiliário urbano atrativo, e acessibilidade;

Os Manuais de uso e operação são referências para melhor gestão dos projetos e edificações de maneira geral. Sabemos que cada edificação possui suas peculiaridades, dificuldades e facilidades. Sabemos que cada gestor tem sua maneira de gerir e trabalhar imprimindo sua personalidade no resultado final. No entanto, é necessário que haja a elaboração de um manual, cronograma e organização de manutenção de cada edificação de saúde buscando atender aos padrões mínimos de salubridade, limpeza, uso e manutenção das máquinas e bom funcionamento do ambiente para oferecer a melhor qualidade aos usuários. A proposta é que cada unidade de saúde crie e apresente à Anvisa os manuais de gestão e manutenção de sistemas a serem cumpridos. Esses manuais serão analisados, assim como se analisa um projeto de arquitetura a ser aprovado. Sendo este manual aprovado, haverá fiscalizações periódicas para conferir se as datas e a qualidade do serviço foram realizadas de maneira esperada, caso contrário, os responsáveis pelas instituições serão advertidos. 


\section{CONSIDERAÇÕES FINAIS}

A dissertação estudou basicamente três temas, o exercício da projetação, a qualidade ambiental dos projetos, uso e manutenção, e a qualidade das edificações de saúde-Hemocentro no Brasil. Em outras palavras, o exercício da projetação e a maneira obsoleta que existe na maioria dos escritórios de engenheiros e arquitetos no Brasil, sem estudar as variações climáticas da localidade, o não envolvimento e interesse da população, técnicos, engenheiros, arquitetos e clientes, em geral, em aperfeiçoar o "projetar", a cultura brasileira da inexistência ou falta de qualidade na gestão e manutenção de edificações, a falta de qualidade projetual, suas adequações e reformas durante a obra, a baixa qualidade do produto gráfico e não acompanhamento em relação às revoluções tecnológicas, a baixa qualidade ambiental das edificações de saúde no Brasil, especificamente os Hemocentros, e a falta de conectividade em relação as normas vigentes (municipal, estadual e federal) para projetos de saúde no Brasil.

Apesar da existência e da formulação de novas normas que busquem auxiliar na melhoria da qualidade do projeto e na adequação às características de cada tipologia e clima, ainda é muito forte no nosso país a prática de projeto que pode ser replicado, copiado e importado. Projetos que não observaram, antes do estudo preliminar, características climáticas, culturais e o entorno para a definição do partido.

Dessa maneira, podemos notar de maneira generalizada edificações em desuso, em constante adequação ou abandonadas devido seu alto consumo energético, novas tecnologias, baixo índice de manutenção e de maneira incorreta.

Tudo isso torna muito oneroso para a sociedade em geral e para o meio ambiente. O tempo gasto, o consumo de recursos naturais, a falta de qualidade ambiental tornam as edificações ineficientes.

A intenção deste trabalho é oferecer embasamento não somente para profissionais e alunos, futuros projetistas, conscientes e engajados em boas práticas de projeto envolvidos com questões ambientais como também auxiliar na formulação de novas normas que possibilitem maior facilidade de projetos com qualidade nesses quesitos.

No decorrer dos estudos foi possível entender a importância da existência e da elaboração dos manuais de manutenção prediais. Muito utilizados nos países desenvolvidos, os manuais auxiliam na qualidade do serviço, na organização, periodicidade, rotina e controle das manutenções. A mão de obra deixa de ser informal, passa a ser qualificada, e possui um papel de importância no aumento da vida útil da edificação.

Infelizmente esses manuais só passam a ser obrigatórios após a NBR 15575 que abarca somente edificações residenciais. Sendo assim, as edificações de saúde, 
comerciais, industriais, entre outras, continuam sem esse avanço no processo de manutenção.

Enfrenta-se então um problema no Brasil, a ineficiência ou inexistência em relação as normativas e a falta de conectividade nas esferas municipais, estaduais e federais, prolongando o tempo de atuação da fiscalização e da aprovação dos projetos.

A lei que regulamenta com elementos técnicos para edificações de saúde não aborda temas relacionados a sustentabilidade, arquitetura bioclimática e nem mesmo auxilia na elaboração de fluxogramas e setorizações.

No Brasil, o quadro de projetação está defasado em relação a outros países, não somente em relação a legislação, mas também em relação aos softwares. O Autocad se mostra como a principal ferramenta de projeto. Poucos escritórios utilizam softwares do sistema BIM e os que usam ainda estão em um estágio inicial, sem grandes avanços.

Os novos softwares disponíveis no mercado possibilitam menor manutenção e maior participação na economia de recursos naturais.

Muitas situações foram encontradas nas edificações em estudo na busca de amenizar efeitos ambientais e climáticos desconfortáveis que foram gerados por uma arquitetura desconectada com o local no qual está inserido e seu entorno, como insulfims, divisórias, iluminação inadequada ou insuficiente, e grande utilização de aparelhos para refrigeração e climatização.

Os aparelhos de ar condicionado, na sua grande maioria, se tratam de peças antigas e não economizadores de energia somando aproximadamente $50 \%$ do consumo energético das edificações estudadas.

Apesar dos aparelhos serem os maiores consumidores de energia, podemos perceber que grande parte dos usuários ainda estão insatisfeitos em relação a temperatura, muito baixa ou muito alta.

Algumas recomendações formuladas para a melhoria da qualidade dessas edificações e para auxiliar novos projetos semelhantes foram desenvolvidas em busca de se tornar um facilitador para projetistas. Acredita-se essas recomendações podem ser fornecidas a comunidade de projetistas buscando acelerar o processo de formulação de programa de necessidades, reduzindo tempo e erros projetuais, elevando a qualidade ambiental dessas edificações em especial.

Os Hemocentros não se tratam de hospitais, e sim de edificações de saúde que alimentam toda a rede hospitalar. Este tipo de EAS lida com doadores e esse tipo de usuário não depende desse atendimento, ele serve essa edificação. Para que os doadores continuem contribuindo gratuitamente há a necessidade de proporcionar um ambiente confortável e atrativo, promovendo maior eficiência nas atividades para o qual o local se propõe. 


\section{REFERÊNCIAS}

ASHRAE fundamentals handbook. Thermal Comfort, cap.8. 1997.

ARAUJO, Eliete de Pinho. Manual Prático de Procedimentos em Estabelecimentos Assistenciais de Saúde. Brasília: Editora Kiron, 2013.

ASSOCIAÇÃO Brasileira de Normas Técnicas (ABNT). NBR 15220: Desempenho Térmico de Edificações. Rio de Janeiro, ABNT, 2003.

. NBR 15575: Edificações Habitacionais - Desempenho. Rio de Janeiro, ABNT, 2013

NBR 5674: Manutenção de edificações - Procedimento. Rio de Janeiro, 1992.

NBR 5462: Confiabilidade e mantenabilidade. Rio de Janeiro, 1994.

NBR 14037: Manual de operação, uso e manutenção das edificações - conteúdo e recomendações para elaboração e apresentação. Rio de Janeiro, 1998.

BONETTI, José Carlos. Pressupostos bioclimáticos de conforto térmico para uma arquitetura dos trópicos úmidos. Dissertação (Mestrado em Ciências Ambientais), Universidade Federal do Amazonas, Manaus, 1999.

BONIN, L.C. Manutenção de edifícios: uma revisão conceitual. In: Anais do Seminário sobre manutenção de edifícios, Porto Alegre: URFGS, 1988.

BOOTY, Frank. Facilities Management Handbook. Oxford: Elsevier Ltda, 2009.

BRASIL. Instrução Normativa MPOG/SLTI no 2, de 4 de junho de 2014.

. Ministério da Saúde. Agência Nacional de Vigilância Sanitária. RDC no 50, de 21 de fevereiro de 2002. Dispõe sobre o Regulamento Técnico para planejamento, programação, elaboração e avaliação de projetos físicos de estabelecimentos assistenciais de saúde. Diário Oficial da República Federativa do Brasil. Brasília, 20 de mar. de 2002.

. Brasil. Agência Nacional de Vigilância Sanitária. Conforto Ambiental em Estabelecimentos Assistenciais de Saúde. Agência Nacional de Vigilância Sanitária. Brasília: Agência Nacional de Vigilância Sanitária, 2014.

CAMPOS, Rodrigo Miguel; VARGAS, Alexandre. Proposta de um plano de manutenção predial preventiva para um edifício residencial. Monografia (Trabalho de Conclusão de Curso - Engenharia Civil), Universidade Estadual de Santa Catarina, 2015. Disponível em < http://repositorio.unesc.net/handle/1/2977>. Acesso em 07 ago. 2016.

CARLO, J. C. ; LAMBERTS, R. Elaboração de protótipos para simulação do desempenho termoenergético de edificações. In: Encontro Nacional de Tecnologia no Ambiente Construído. Florianópolis, 2006. Porto Alegre: ANTAC, 2006. v. 1. p. 152-161. Disponível em < http://www.infohab.org.br/entac2014/2006/artigos/ENTAC2006_0152_161.pdf>. Acesso em 08 ago. 2016.

Estratégias Bioclimáticas para a cidade de Manaus. In: Anais IX Encontro Nacional de Tecnologia do Ambiente Construído. Foz Do Iguaçu, Paraná, 2002. Disponível em < http://www.infohab.org.br/entac2014/2002/Artigos/ENTAC2002_0153_162.pdf>. Acesso em 31 ago. 2016.

CUNHA, L. J. B. F. Análise de métodos para aplicação de ventilação natural para projeto de edificação em Natal-RN. Dissertação (Mestrado em Arquitetura e Urbanismo) Programa de PósGraduação em Arquitetura e Urbanismo da Universidade Federal do Rio Grande do Norte. Natal, 2010.

EASTMAN, C. et. al. BIM Handbook: a Guide to Building Information Modeling for Owners, Managers, Designers, Engineers and Contractors. New Jersey: Jonh Wiley \& Sons, 2008.

FANGER, P.O., Thermal comfort analysis and applications in environmental engineering, Copenhague: Danish Technical Press, 1970.

FERREIRA, P. C. Alguns dados sobre o clima para a edificação em Brasília. Dissertação (Mestrado em Arquitetura e Urbanismo). Faculdade de Arquitetura e Urbanismo, Universidade de Brasília, Brasília, 1965 
GIVONI, B. Comfort Climate Analysis and Building Design Guidelines. Energy and Building, 1992. . Man, climate and architecture. Londres: Elsevier, 1992.

GOES, Ronald de. Manual Prático de Arquitetura Hospitalar. São Paulo: Editora Edgard Bluncher, 2004.

Manual Prático de Arquitetura para Clínicas e Laboratórios. São Paulo: Editora Edgard Bluncher. 2006

GOMIDE, Tito L. F., et. al. Técnicas de inspeção e manutenção predial. São Paulo: PINI, 2006.

GRIGOLETTI, Giane de Campos. Método de avaliação de desempenho higrotérmico de habitações térreas unifamiliares de interesse social para Porto Alegre - RS. Tese (Doutorado em Engenharia Civil) - Escola de Engenharia, Universidade Federal do Rio Grande do Sul, Porto Alegre, 2007.

HALL, Edward. Dimensão Oculta. Madri, Espanha: Siglo XXI Editores, 1999.

HEYER, Lígia Fonseca. Manaus - Um exemplo de clima urbano em região subequatorial.Tese (Doutorado em Geografia) - Universidade de São Paulo, São Paulo, 1997.

HOWARD, Rob; BJÖRK, Bo-Christer . Building information modelling - experts' views on standardization and industry deployment. In: Advanced Engineering Informatics, Vol 22, No. 2, p. 271-280. Helsinki, 2008.

INSTITUTO Nacional de Metrologia, Normalização e Qualidade Industrial (INMETRO). Requisitos Técnicos de Qualidade para o Nível de Eficiência Energética de Edifícios Comerciais, de Serviços e Públicos. INMETRO - Portaria 372, setembro 2010.

KELLY, Martin. The UK Facilities Management Sector. In: International Corporate Rescue. United Kingdom, v. 8, n. 2, 2011.

KUINCHTNER, Angelica; BURIOL, Galileo Adeli. Clima do Estado do Rio Grande do Sul segundo a classificação climática de Köppen e Thornthwaite. In: Disciplinarum Scientia. Série: Ciências Exatas, Santa Maria, v. 2, n.1, p. 171-182, 2001.

LAMBERTS, R; DUTRA, L; PEREIRA, F. O. R. Eficiência energética na arquitetura. São Paulo: PW, 2003.

Laboratório de Sustentabilidade Aplicada à Arquitura e Urbanismo - Universidade de Brasília (LASUS). Hemorrede Sustentável - HEMORGS. Brasília, 2015. Disponível em:

http://www.lasusunb.com/uploads/4/7/1/6/47165497/2014 hemorgs relat\%C3\%B3rio final.compress ed.pdf. Acesso em 18 nov. 2015.

Projeto de Adequação do Hemocentro Público do DF. Avaliação Pós Ocupação, Diagnóstico Energético e Etiquetagem. Brasília, 2011. Disponível em: http://www.lasusunb.com/uploads/4/7/1/6/47165497/2011 fhb relatorio vol1 final.compressed.pdf.

Acesso em 19 nov. 2015. Vol. 1

Projeto de Adequação do Hemocentro Público do RJ. Avaliação Pós Ocupação, Diagnóstico Energético e Etiquetagem. Brasília, 2012. Disponível em: http://www.lasusunb.com/uploads/4/7/1/6/47165497/2012 hemorio relatorio vol1 final.compressed.p df. Acesso em 19 nov. 2015. Vol. 1

LUKIANTCHUKI, Marieli Azoia e CARAM, Rosana Maria. Arquitetura Hospitalar e o Conforto Ambiental: Evolução Histórica e Importância na Atualidade. In: Anais do 7ํㅗㄴ Seminário Internacional do Núcleo de Pesquisa em Tecnologia da Arquitetura e Urbanismo - NUTAU, 2008. Disponível em <<http://www.usp.br/nutau/CD/160.pdf>> , acessado em 13 fev. 2016.

MACIEL, Alessandra Albuquerque. Projeto Bioclimático em Brasília: Estudo de Caso em Edifícios de Escritórios. Dissertação (Mestrado em Engenharia Civil) - Universidade Federal de Santa Catarina, Florianópolis, 2002.

MASCARÓ, J. L. O custo das decisões arquitetônicas. São Paulo: Ed. Nobel 1985.

MINISTÉRIO DE MINAS E ENERGIA. Consumo de Energia no Brasil Análises Setoriais. Rio de Janeiro: MME, 2014.

Regulamento Técnico da Qualidade para o Nível de Eficiência Energética e 
Etiquetagem de Edifícios Comerciais, de Serviços e Públicos. Brasília, 2010

MORAES, Virgínia Tambasco Freire; QUELHAS, Osvaldo Luiz Gonçalves. O Desenvolvimento da Metodologia e processos de um "retrofit" arquitetônico. In: Sistemas \& Gestão Revista Eletrônica. V. 7, n. 3, 2012, p. 448-461 DOI: 10.7177/sg.2012.v7.n3.a13

NIMER, E.. Climatologia do Brasil. SUPREN/IBGE. Volume 4, 1979.

OLGYAY, V. Design with climate bioclimatic approach to architecture regionalism. Nova Jersey: Universidade de Princeton. 3 . ed,1973.

Clima e arquitetura em Colômbia. Universidade del Valle. Faculdade de Arquitetura, Cali, Colômbia. 1968.

ORNSTEIN, Sheila W.; BRUNA, Gilda; ROMÉRO Marcelo. Ambiente construído e comportamento: a avaliação pós ocupação e a qualidade ambiental. São Paulo: Studio Nobel, Edusp, 1995.

ORNSTEIN, Sheila; ROMÉRO Marcelo. Avaliação pós-ocupação do ambiente construído. São Paulo: Studio Nobel, Edusp, 1992.

PREISER, W., RABINOWITZ, H., WHITE E. Rehabilitation, renovation, and reconstrution of buildings. Proceedings of a workshop sponsord by tha National Science Foundation and the American Society of Civil Engineers. New York, 1988.

PROCEL EDIFICA EDIFICA - EFICIÊNCIA ENERGÉTICA EM EDIFICAÇÕES (PROCEL EDIFICA EDIFICA).BARROSO-KRAUSE, C. Desempenho Térmico e Eficiência Energética em Edificações. Rio de Janeiro, PROCEL EDIFICA EDIFICA, agosto 2011.

PROCEL EDIFICA EDIFICA - EFICIÊNCIA ENERGÉTICA EM EDIFICAÇÕES (PROCEL EDIFICA EDIFICA).LONARDO, L.L.B. Eficiência Energética em Edifícios e Sustentabilidade no Ambiente Construído. Rio de Janeiro, PROCEL EDIFICA EDIFICA, agosto 2011.

PROCEL EDIFICA EDIFICA - EFICIÊNCIA ENERGÉTICA EM EDIFICAÇÕES (PROCEL EDIFICA EDIFICA).GONÇALVES, J.C.S.; VIANNA, N.S.; MOURA, N.C.S. Iluminação Natural e Artificial Rio de Janeiro, PROCEL EDIFICA EDIFICA, agosto 2011.

PROCEL EDIFICA EDIFICA - EFICIÊNCIA ENERGÉTICA EM EDIFICAÇÕES (PROCEL EDIFICA EDIFICA). SIMÕES, F.M. Acústica Arquitetônica. Rio de Janeiro, PROCEL EDIFICA EDIFICA, agosto 2011.

ROMERO, Marta Adriana Bustos. Arquitetura do lugar: uma visão bioclimática da sustentabilidade em Brasília, São Paulo: Ed. Nova Técnica Editorial, 2011.

Arquitetura Bioclimática do Espaço Público. Brasília: UnB, 2001. UnB, 2011.

Tecnologia e Sustentabilidade para a humanização dos edifícios de saúde. Brasília:

Estratégias bioclimáticas de reabilitação ambiental adaptadas ao projeto. material didático reabilita. Brasília: UNB, 2013.

ROCHA. Marcius H., QUALHARINI, E. L. Modelagem gerencial de sistemas de manutenção de edificações históricas. In: Construção, Lisboa, dezembro de 2001, p.137-144.

ROSSI, P.; FREEMAN, H.. Evaluácion: un enfoque sistemático. New York: Sage, 1989.

SILVA, Roberto Toffoli Simoens da. Preservação e sustentabilidade: restaurações e retrofits. 2013. Dissertação (Mestrado - Área de concentração: Projeto de Arquitetura) - Faculdade de Arquitetura e Urbanismo, Universidade de São Paulo. São Paulo, 2013. 112 p.

SOUZA, L; LYRIO, A.; AMORIM, S. Impactos do Uso do BIM em Escritórios de Arquitetura: Oportunidades no Mercado Imobiliário. In: Anais IV Encontro de Tecnologia de Informação e Comunicação na Construção Civil, Rio de Janeiro, 2009.

TOLEDO, Luiz Carlos. Feitos para Curar: arquitetura hospitalar e processo projetual no Brasil. Rio de Janeiro: ABDEH, 2006.

TOBIN, J. Proto-Building: To BIM is to Build. AECbytes, 28 mai. 2008. Disponível em: < http://www.aecbytes.com/buildingthefuture/2008/ProtoBuilding.html > Acesso em: 3 out. 2013. 
VALE, Maurício Soares do. Diretrizes para racionalização e atualização das edificações: segundo o conceito da qualidade e sobre a ótica do retrofit. Dissertação (Mestrado em Arquitetura e Urbanismo) - Universidade Federal do Rio de Janeiro, Rio de Janeiro, 2006. 
ANEXOS

ANEXO 1

Anexo 1: Modelo de Ficha de manutenção para Ar Condicionado

\begin{tabular}{|c|c|c|c|c|c|c|c|c|c|c|}
\hline Tipo & Atividade & $\begin{array}{c}\text { Data } \\
\text { prevista }\end{array}$ & $\begin{array}{c}\text { Data } \\
\text { execuçầo }\end{array}$ & Cód. & $\begin{array}{c}\text { Data } \\
\text { prevista }\end{array}$ & $\begin{array}{c}\text { Data } \\
\text { execução }\end{array}$ & Cód. & $\begin{array}{c}\text { Data } \\
\text { prevista }\end{array}$ & $\begin{array}{c}\text { Data } \\
\text { execução }\end{array}$ & Cód. \\
\hline ME & $\begin{array}{l}\text { Limpar } \\
\text { externa e } \\
\text { internamente } \\
\text { o gabinete }\end{array}$ & & & & & & & & & \\
\hline TR & $\begin{array}{l}\text { Limpar o } \\
\text { evaporador }\end{array}$ & & & & & & & & & \\
\hline TR & $\begin{array}{l}\text { Limpar o } \\
\text { condensador }\end{array}$ & & & & & & & & & \\
\hline ME & $\begin{array}{l}\text { Verificar } \\
\text { bandeja e } \\
\text { desobstruir o } \\
\text { dreno }\end{array}$ & & & & & & & & & \\
\hline TR & $\begin{array}{l}\text { Inspecionar } \\
\text { e regular o } \\
\text { termostato }\end{array}$ & & & & & & & & & \\
\hline $\mathrm{TR}$ & $\begin{array}{l}\text { Inspecionar } \\
\text { estado do } \\
\text { protetor } \\
\text { térmico do } \\
\text { compressor }\end{array}$ & & & & & & & & & \\
\hline SE & $\begin{array}{l}\text { Verificar } \\
\text { resistência } \\
\text { elétrica do } \\
\text { enrolamento } \\
\text { dos motores e } \\
\text { do compressor }\end{array}$ & & & & & & & & & \\
\hline
\end{tabular}

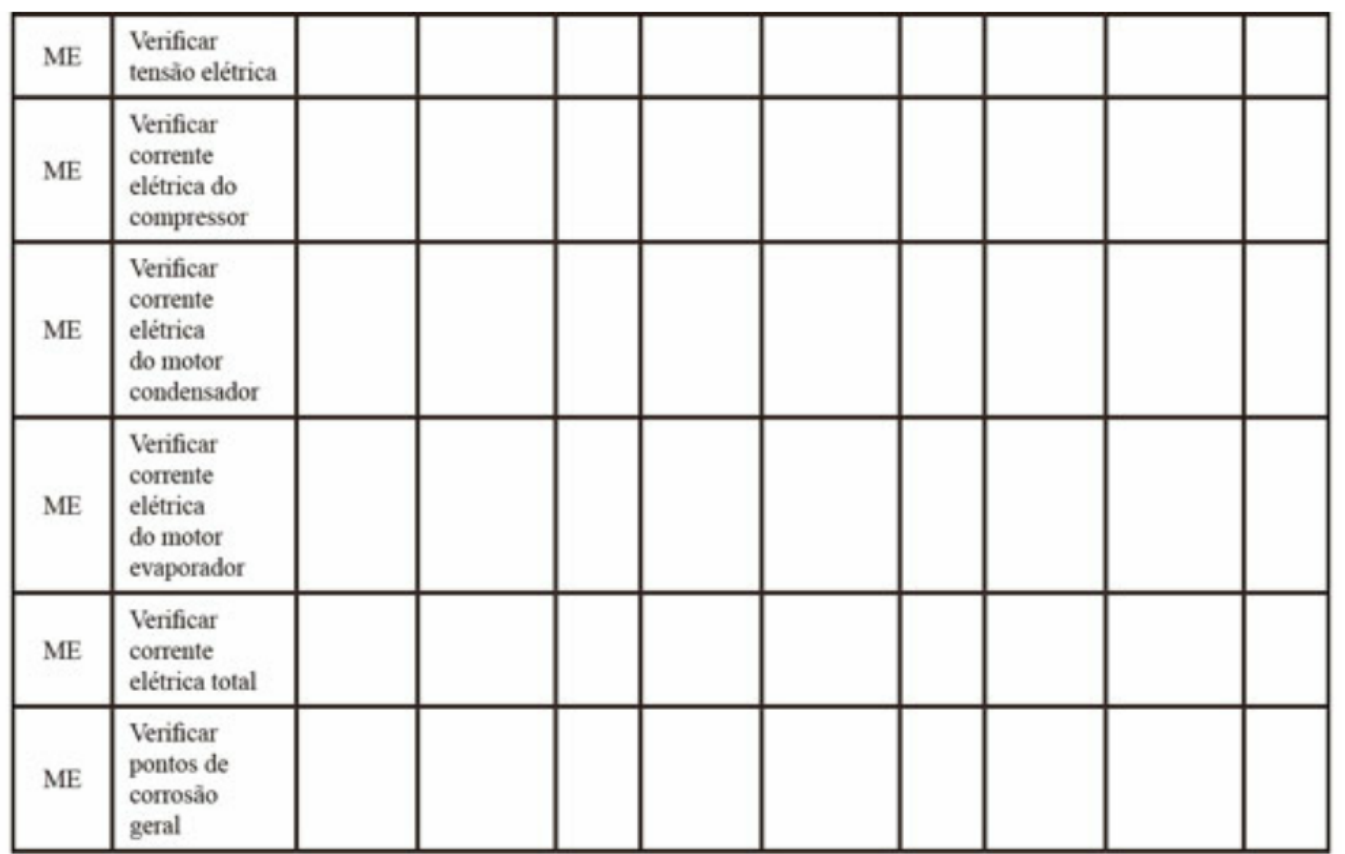




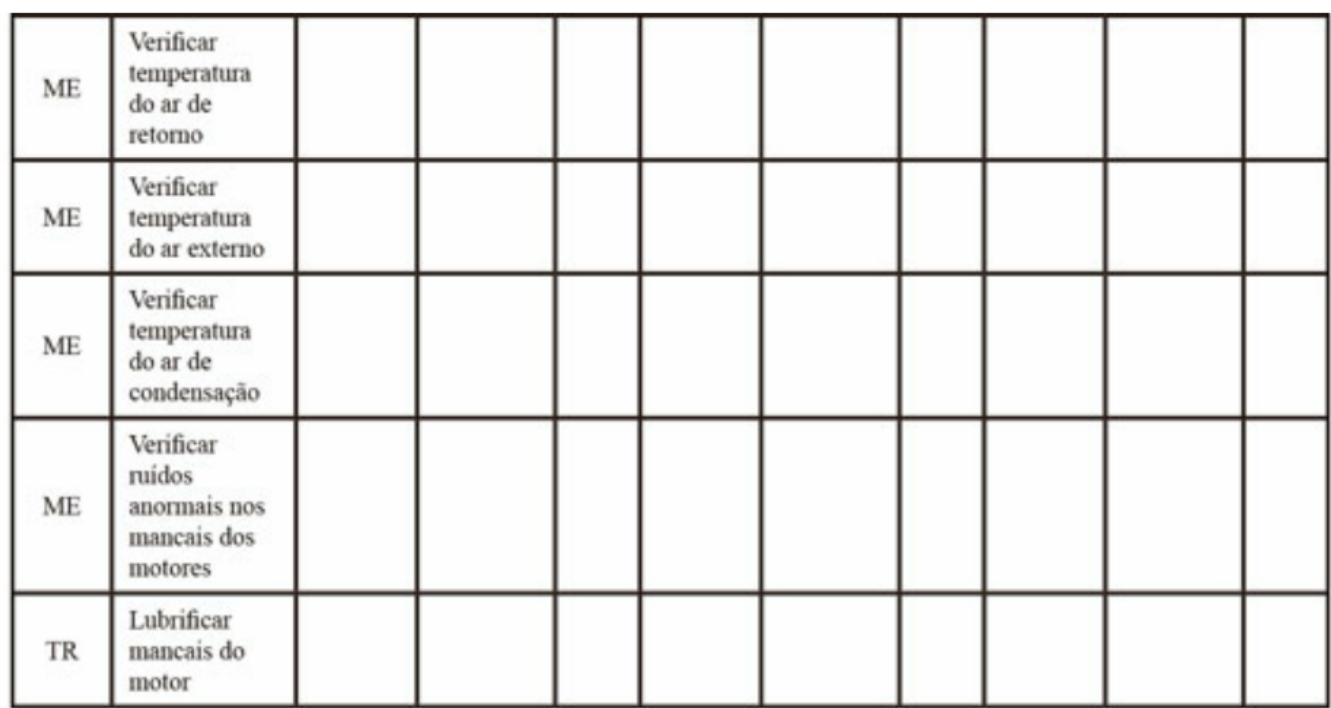

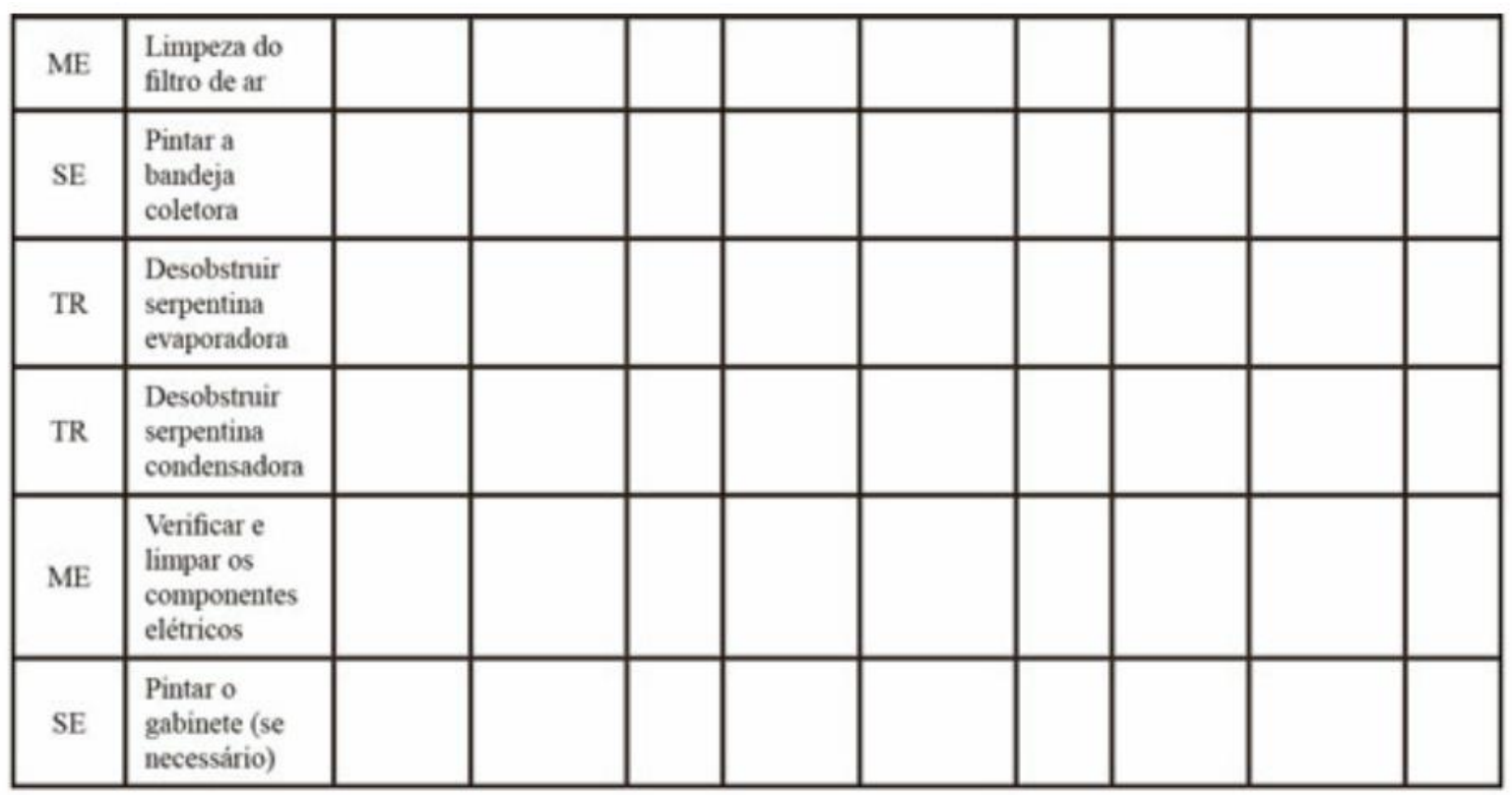

Vistos do encarregado

\begin{tabular}{|c|c|c|c|c|c|}
\hline Códigos & ME $=$ Mensal & TR $=$ Trimestral & $\mathrm{SE}=$ Semestral & & \\
\hline & $\mathrm{E}=$ Executado & $\mathrm{C}=$ Precisa correção & $\mathrm{T}=$ Trocado & $\mathrm{B}=\mathrm{Bom}$ & $\mathrm{R}=$ Precisa correção urgente \\
\hline
\end{tabular}

Fonte: Araujo, 2013 